FERNANDO LUIS VELÁZQUEZ

\title{
AVALIAÇÃO DOS SISTEMAS CICLOVIÁRIOS DE TRÊS CIDADES DO INTERIOR DO ESTADO DE SÃO PAULO
}

Dissertação apresentada à Escola De Engenharia de São Carlos, Universidade de São Paulo, como parte dos requisitos para a obtenção do título de Mestre em Engenharia Civil, Pós-graduação em Engenharia de Transportes.

Área de Concentração: Planejamento e Operações de Sistemas de Transportes

Orientador: Prof. Titular Antônio Clóvis Pinto Ferraz

São Carlos 
AUTORIZO A REPRODUÇÃO TOTAL OU PARCIAL DESTE TRABALHO, POR QUALQUER MEIO CONVENCIONAL OU ELETRÔNICO, PARA FINS DE ESTUDO E PESQUISA, DESDE QUE CITADA A FONTE.

Ficha catalográfica preparada pela Seção de Tratamento da Informação do Serviço de Biblioteca - EESC/USP

Velázquez, Fernando Luis
Avaliação dos sistemas cicloviários de três cidades do
interior do estado de São Paulo. / Fernando Luis
Velázquez; orientador Antônio Clóvis Pinto Ferraz. São
Carlos, 2014.
Dissertação (Mestrado) - Programa de Pós-Graduação em
Engenharia de Transportes e Área de Concentração em
Planejamento e Operações de Sistemas de Transportes --
Escola de Engenharia de São Carlos da Universidade de
São Paulo, 2014.
1. Sistema cicloviário. 2. Infraestrutura cicloviária.
C. Ciclovias. 4. Ciclofaixas. 5. Avaliação. I. Título.




\section{FOLHA DE JULGAMENTO}

Candidato: Arquiteto e Urbanista FERNANDO LUÍs VELAZQUEZ.

Título da dissertação: "Avaliação dos sistemas cicloviários de três cidades do interior do estado de São Paulo".

Data da defesa: 09/05/2014

Comissão Julgadora:

Prof. Titular Antonio Clóvis Pinto Ferraz (Orientador)

(Escola de Engenharia de São Carlos/EESC)

Profa. Titular Suely da Penha Sanches

(Universidade Federal de São Carlos/UFSCar)

\section{Resultado:}

APIOUADO

APROVADO

Profa. Dra. Luzenira Alves Brasileiro

APROVADO

(Universidade Estadual Paulista "Júlio de Mesquita Filho"/UNESP-Ilha Solteira)

Coordenador do Programa de Pós-Graduação em Engenharia de Transportes:

Prof. Associado Antônio Nélson Rodrigues da Silva

Presidente da Comissão de Pós-Graduação:

Prof. Titular Denis Vinicius Coury 

À minha família, Danúbio, Maria Dulce e Hugo, pelo apoio incondicional de todas as horas, sempre com amor, alegria e incentivo.

À minha esposa que amo sem fim, Maíra, pelos momentos maravilhosos e inesquecíveis, sempre com amor, carinho e respeito. Nossa jornada está apenas começando.

Sem você nada mais faria sentido. 

Ao orientador, Professor Coca Ferraz, pela paciência, amizade, ensinamentos e principalmente confiança em minhas capacidades como orientado, oferecendo suporte para meu crescimento profissional e pessoal.

Aos professores Antônio Nélson Rodrigues da Silva e Suely da Penha Sanches pelas valiosas contribuições durante e após a banca de qualificação, além das conversas em sala, essenciais à conclusão deste trabalho.

A todos os professores da STT pelos essenciais conhecimentos oferecidos durante aulas, palestras e conversas informais e a todos os exemplares funcionários deste departamento.

Aos meus queridos amigos da sala mais engraçada do departamento (Orientados do Coca: Lugar de gente feliz), Diego Neris, Fernando Hideki Hirose, vulgo "Sorriso" e Magaly Romão. Obrigado pelas conversas, conselhos e paciência durante esses dois anos de muito aprendizado e alegria.

A todos os inesquecíveis amigos que convivi: Mateus Gama, Fernando Piva, Artur Piatti, Andrea Nicola, Heymar Aranciba, Gláucia Maia, Conrado Plaza, Javier Mahecha, Edgar Páez, Antônio Carvalho Filho, Marcela Navarro, Antônio Nilson e Gabi Morais. Obrigado a todos pelas horas de estudos, pelos risos e pela grande ajuda nos trabalhos de campo. Obrigado a todos.

À minha incrível família, meu pai Danúbio, mãe Maria Dulce e meu irmão Hugo. Sem vocês nada disso seria possível. Agradeço pela educação e oportunidades, sempre oferecendo apoio e estímulo, independente da dificuldade.

À Maíra, esposa e companheira que sempre está ao meu lado independente da situação, sempre com amor, carinho e respeito. Demonstra em pequenos gestos o quanto ama, o quanto gosta e o quanto se preocupa.

Ao CNPq (Conselho Nacional de Desenvolvimento Científico e Tecnológico) pelo apoio financeiro. 

"Comece fazendo o que é necessário, depois o que é possível, e de repente você estará fazendo o impossível." 

VELÁZQUEZ, F. L. Avaliação dos sistemas cicloviários de três cidades do interior do estado de São Paulo. 2014. Dissertação (Mestrado) - Escola de Engenharia de São Carlos, Universidade de São Paulo, São Carlos, 2014.

Neste trabalho são investigadas as razões da maior utilização do sistema cicloviário na cidade de Rio Claro em relação à Araraquara e São Carlos, e descobrir os principais motivos da baixa demanda de usuários nas ciclovias e ciclofaixas das cidades de Araraquara e São Carlos. Esse objetivo visa compreender também o porquê da utilização ou não do espaço destinado ao tráfego de bicicletas. Tal objetivo auxilia na obtenção de informações que possam ajudar no planejamento e no projeto da implantação de ciclovias e ciclofaixas nas cidades brasileiras. Também é realizada uma avaliação individual dos segmentos cicloviários (ciclovias e ciclofaixas) existentes nas três cidades objeto do estudo e uma avaliação geral do sistema cicloviário das mesmas, mediante, sobretudo, a comparação de dados quantitativos. O uso muito maior do modal bicicleta em Rio Claro deve-se aos seguintes principais fatores: preponderância de vias com baixa declividade na maior parte da área urbana, qualidade insatisfatória do transporte coletivo nas últimas décadas, renda média inferior da população e maior influência da cultura europeia (alemã e italiana) na colonização da cidade - países que têm grande tradição no uso da bicicleta. Os principais fatores inibidores do uso do modal bicicleta em São Carlos são: topografia acidentada (em grande parte da área urbana as vias tem rampas acentuadas), maior nível de desenvolvimento socioeconômico e falta de tradição/cultura do uso da bicicleta. Em Araraquara, são: boa qualidade do transporte coletivo nas últimas décadas, maior nível de desenvolvimento socioeconômico e falta de tradição/cultura do uso da bicicleta. São ainda discutidos os seguintes pontos relevantes: tipos de segmentos cicloviários $x$ visão da população, impacto da bicicleta na fluidez do trânsito e segurança no uso da bicicleta.

Palavras-chave: Sistema cicloviário. Infraestrutura cicloviária. Ciclovias. Ciclofaixas. Avaliação. 
VELÁZQUEZ, F. L. Evaluation of cycling systems in three cities in the state of São Paulo. 2014. Dissertação (Mestrado) - Escola de Engenharia de São Carlos, Universidade de São Paulo, São Carlos, 2014.

This research investigates the reasons for the increased use of cycling system in the city of Rio Claro in relation to Araraquara and São Carlos, and discover the main reasons for the low demand of users in bicycle tracks and lanes of the cities of Araraquara and São Carlos. This goal also aims to understand why the use or not of the installation to bicycle traffic. This goal is important to obtain information that may help in the planning and implementation of bicycle paths and lanes project in Brazilian cities. An individual evaluation of existing cycling segments (bike paths and lanes) in the three cities subject of the study and an overall assessment of cycling system of them, highlighting the comparison of quantitative data performed. The far greater use of the bicycle modal in Rio Claro is due to the following main factors: preponderance of routes with low slope in most of the urban area, poor quality of public transport in recent decades, lower average incomes and greater influence of culture European (German and Italian) in the colonization of the city - countries that have great tradition in bicycle use. The main factors inhibiting the use of bicycle modal in São Carlos are: topography (largely urban area routes have steep ramps), higher level of socioeconomic development and lack of tradition / culture of cycling. In Araraquara, are: better quality of public transport in recent decades, higher socioeconomic level of development and lack of tradition / culture of cycling. Are still discussed the following relevant points: types of cycling segments $\mathrm{x}$ population's point of view, impact of bicycles in traffic flow and safety on bicycle use.

Keywords: Cycling systems. Cycling infrastructure. Bike paths. Bike lanes. Evaluation. 
Figura 1.1: Localização dos municípios das cidades estudadas..........................25

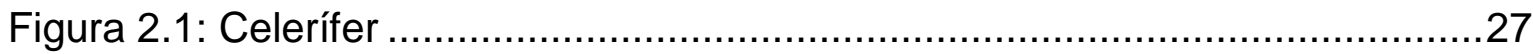

Figura 2.2: Extensão cicloviária em algumas cidades do mundo..........................32

Figura 2.3: Total de municípios e extensão de quilômetros de ciclovias por dimensão populacional de municípios brasileiros maiores que 60 mil

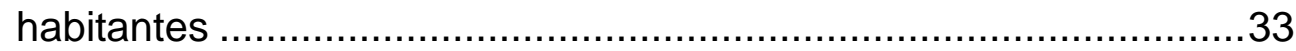

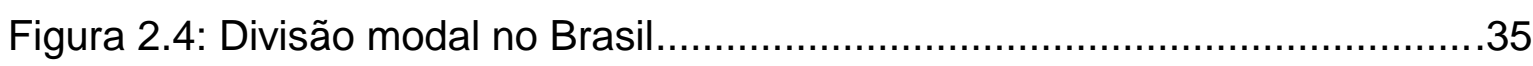

Figura 2.5: Divisão modal entre cidades entre 250 mil e 500 mil habitantes .........36

Figura 2.6: Extensão cicloviária em algumas cidades do Brasil............................38

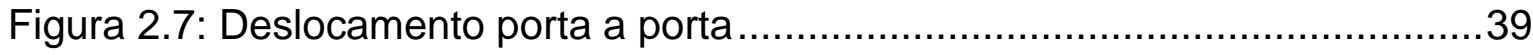

Figura 2.8: Mapa de rede Cicloviária e Corredores de Ônibus de Bogotá .............55

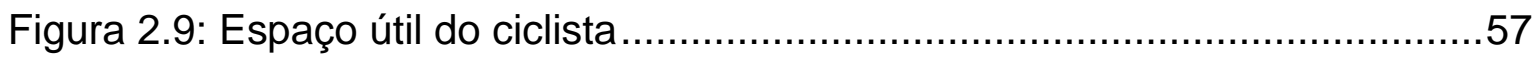

Figura 2.10: Espaço requerido por modo de transporte ......................................58

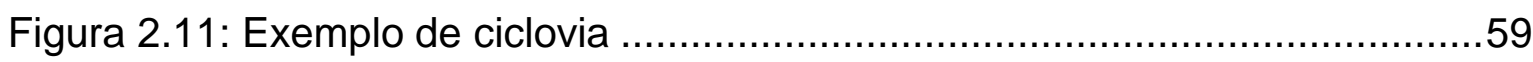

Figura 2.12: Exemplo de ciclovia unidirecional sem desnível .............................60

Figura 2.13: Exemplo de ciclovia unidirecional com desnível .............................60

Figura 2.14: Exemplo de ciclovia unidirecional com vegetação lateral .................60

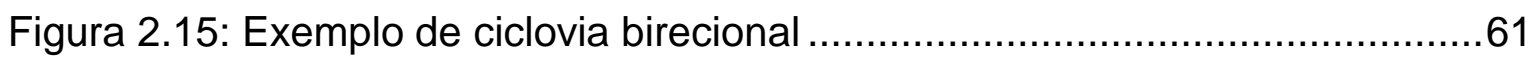

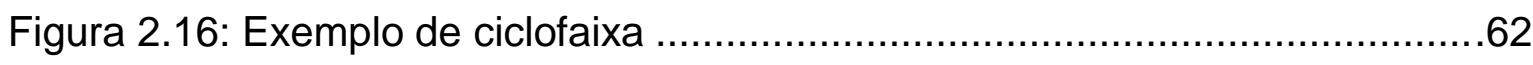

Figura 2.17: Posicionamento de ciclofaixa: Situação 1 ……................................63

Figura 2.18: Posicionamento de ciclofaixa: Situação 2 …...................................63

Figura 2.19: Posicionamento de ciclofaixa: Situação 3 e 4 ....................................64

Figura 2.20: Rampas admissíveis em ciclovias e ciclofaixas ...............................64

Figura 2.21: Via ciclável de uso compartilhado em Curitiba/PR ...........................66

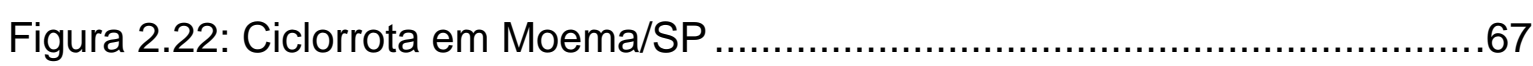

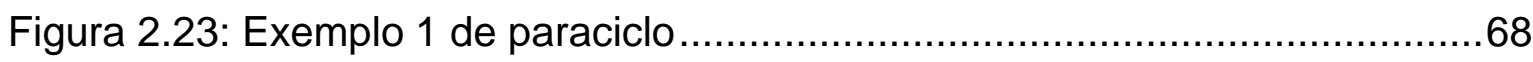

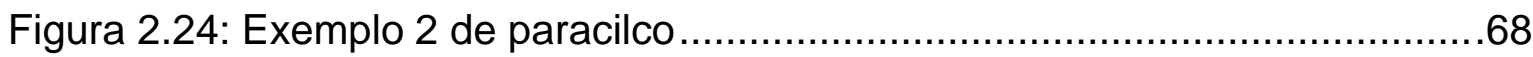

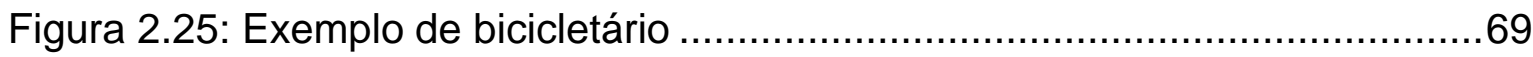

Figura 2.26: Exemplo de bicicletário na cidade de São Paulo ................................69

Figura 3.1: Mapa com as principais vias da cidade de Araraquara.......................72

Figura 3.2: Localização dos segmentos cicloviários de Araraquara......................73

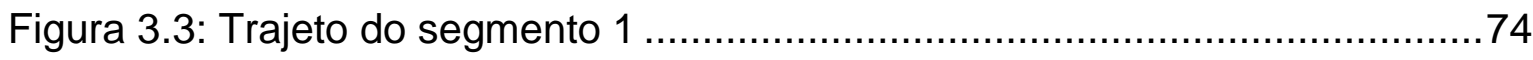


Figura 3.4: Seção transversal do sistema viário no segmento .75

Figura 3.5: Cruzamento com sinalização horizontal apagada................................75

Figura 3.6: Não existência de placa indicativa de segmento cicloviário à frente...75

Figura 3.7: Placa indicativa de cruzamento cicloviário à frente .............................76

Figura 3.8: Sinalização horizontal em estado satisfatório na ciclovia e quase totalmente apagada no cruzamento com a rua ...............................76

Figura 3.9: Grama invadindo a ciclovia e calombo no asfalto ..............................76

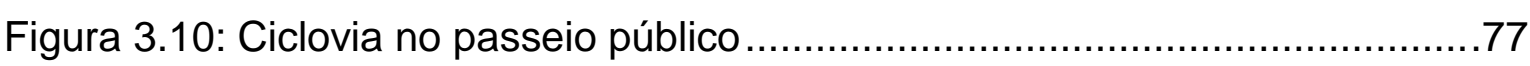

Figura 3.11: Aspecto geral da ciclovia no trecho 3.........................................

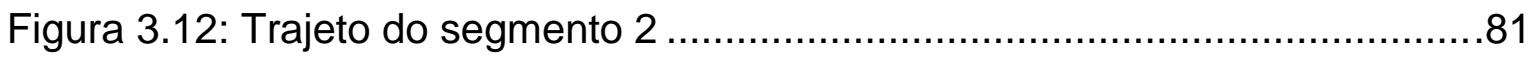

Figura 3.13: Seção transversal do sistema viário no segmento ............................... 81

Figura 3.14: Inexistência de sinalização horizontal indicativa da presença de

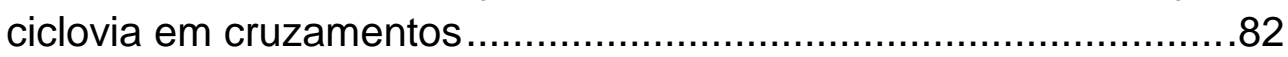

Figura 3.15: Inexistência de sinalização horizontal indicativa da presença do "caminho" para ciclistas em rotatórias............................................... 82

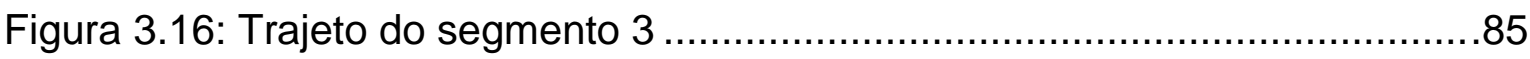

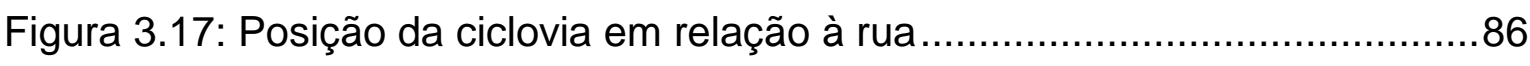

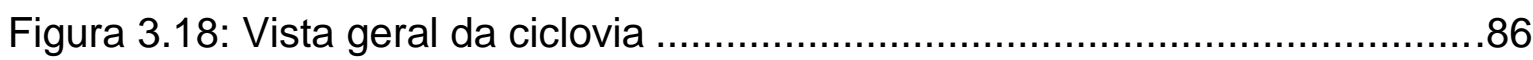

Figura 3.19: Extremidade da ciclovia junto ao Instituto de Química.......................86

Figura 3.20: Extremidade da ciclovia junto ao Campus da UNESP .......................86

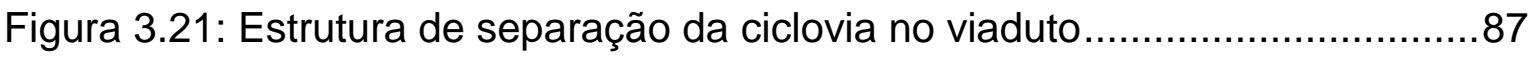

Figura 3.22: Trecho com sinalização horizontal adequada ................................87

Figura 3.23: Trecho com sinalização horizontal inadequada: sem linha divisória de fluxos e com marca antiga de sinalização anterior a implantação da

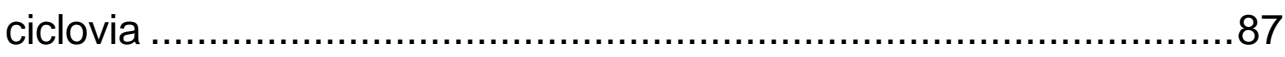

Figura 3.24: Placa de sinalização vertical deteriorada .......................................87

Figura 4.1: Mapa com as principais vias da cidade de São Carlos........................92

Figura 4.2: Divisão modal das viagens em São Carlos......................................92

Figura 4.3: Localização dos segmentos cicloviários de São Carlos ......................94

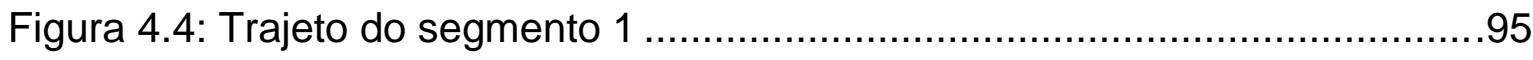

Figura 4.5: Seção transversal do sistema viário no segmento ..............................95

Figura 4.6: Extremidade do segmento distante do Shopping Center ....................96

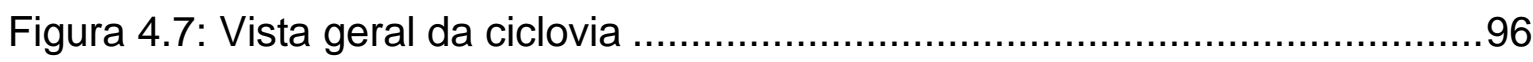

Figura 4.8: Extremidade do segmento próxima do Shopping Center....................96 


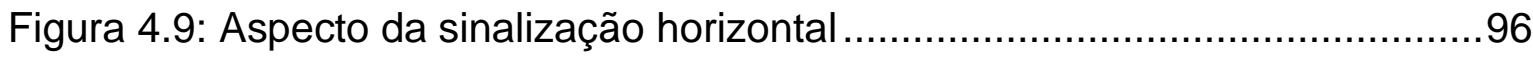

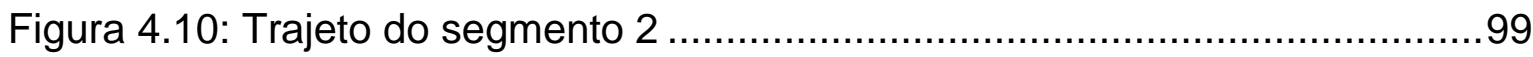

Figura 4.11: Seção transversal do sistema viário no segmento ..........................100

Figura 4.12: Sinalização da ciclovia em cruzamento com via transversal............100

Figura 4.13: Vista da sinalização da ciclovia em interseção com rotatória .........100

Figura 4.14: Vista da sinalização da ciclovia..................................................100

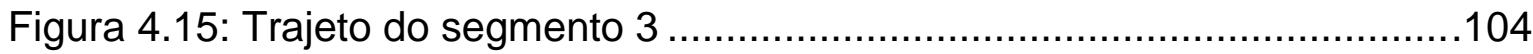

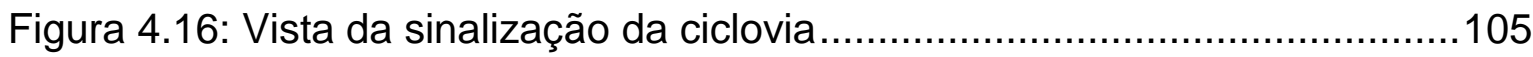

Figura 4.17: Vista da sinalização da ciclovia...................................................105

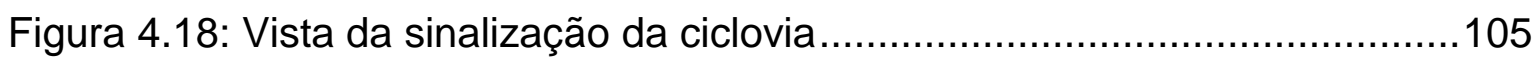

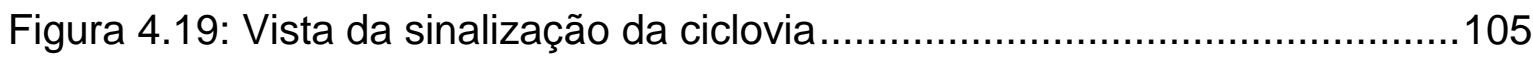

Figura 4.20: Vista da sinalização da ciclovia...................................................105

Figura 4.21: Vista da sinalização da ciclovia..................................................105

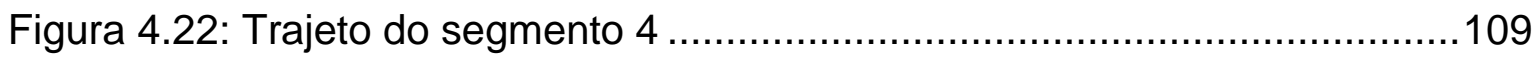

Figura 4.23: Fim da ciclovia no Bairro Cidade Aracy .......................................109

Figura 4.24: Início da ciclofaixa no Bairro Cidade Aracy ....................................109

Figura 4.25: Fim da ciclofaixa no Bairro Monte Carlo ......................................110

Figura 4.26: Início da ciclovia no Bairro Monte Carlo.......................................110

Figura 4.27: Aspecto geral da ciclofaixa …………..................................110

Figura 4.28: Defeito no pavimento da ciclovia...............................................110

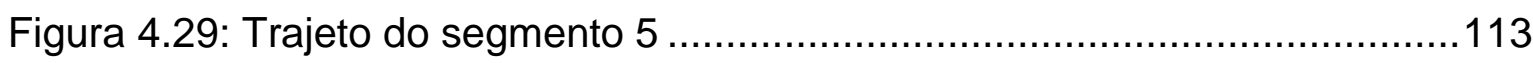

Figura 4.30: Extremidade da ciclovia próxima da Estação Rodoviária.................113

Figura 4.31: Trecho intermediário com ida e volta separados ..........................113

Figura 4.32: Trecho intermediário com ida e volta juntos..................................114

Figura 4.33: Extremidade da ciclovia distante da Estação Rodoviária.................114

Figura 4.34: Trajeto do segmento 6 .......................................................117

Figura 4.35: Extremidade da ciclovia junto à Rodovia São Carlos - Broa ...........117

Figura 4.36: Aspecto geral da ciclovia em trecho com guia separadora do acostamento

Figura 4.37: Aspecto geral da ciclovia em trecho sem guia separadora do acostamento

Figura 4.38: Vista da sinalização da ciclovia..................................................117

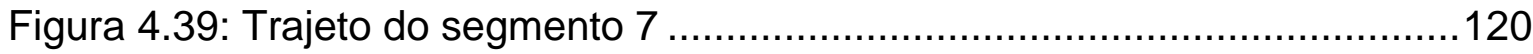

Figura 4.40: Rio canalizado, ciclovia, passeio para pedestres e rua...................120 
Figura 4.41: Aspecto geral da ciclovia e da sinalização .120

Figura 4.42: Ciclovia e rua paralela com fluxo intenso ........................................121

Figura 4.43: Passeio para pedestres ao lado da ciclovia .................................121

Figura 4.44: Extremidade da ciclovia mais distante do Shopping Center ...........121

Figura 4.45: Sinal de parada obrigatória no cruzamento com via transversal.....121

Figura 4.46: Extremidade da ciclovia próxima do Shopping Center....................121

Figura 5.1: Mapa com as principais vias da cidade de Rio Claro.......................128

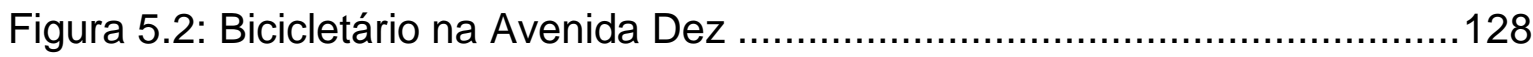

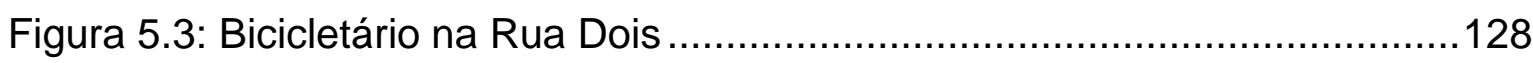

Figura 5.4: Localização dos segmentos cicloviários de Rio Claro.......................130

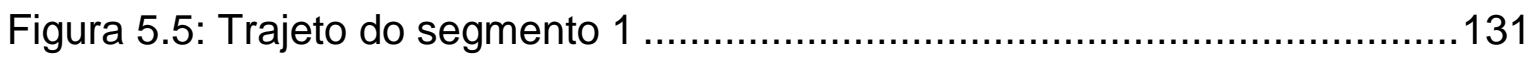

Figura 5.6: Seção transversal do sistema viário no segmento 1 ........................131

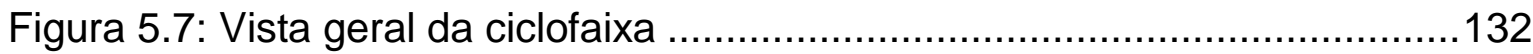

Figura 5.8: Sinalização típica em um cruzamento já bastante apagada .............132

Figura 5.9: Forma de sinalização nos pontos de ônibus ...................................132

Figura 5.10: Falta de sinalização em um cruzamento .......................................132

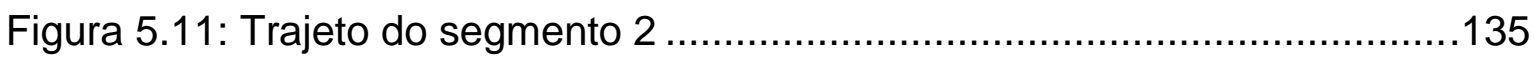

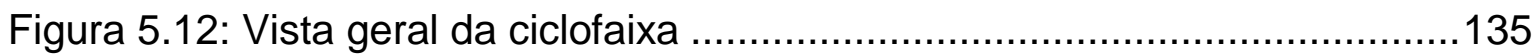

Figura 5.13: Sinalização típica no cruzamento..............................................135

Figura 5.14: Sinalização desgastada em um trecho em curva ............................136

Figura 5.15: Local com defeito no pavimento...............................................136

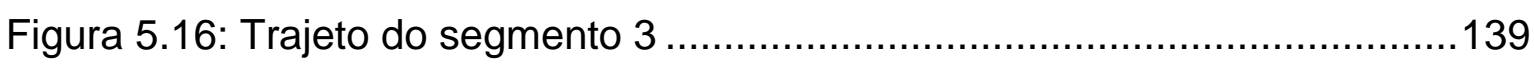

Figura 5.17: Seção transversal do sistema viário no segmento .........................139

Figura 5.18: Sinalização em um cruzamento ................................................139

Figura 5.19: Trecho da ciclovia sem pavimento ………................................139

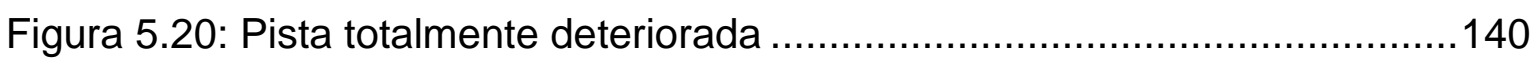

Figura 5.21: Trecho com má conservação ……………...............................140

Figura 5.22: Trecho com má conservação e bloqueio à frente ..........................140

Figura 5.23: Vista geral da ciclovia em um trecho bem conservado ..................140

Figura 5.24: Pista totalmente deteriorada em uma das extremidades ................140

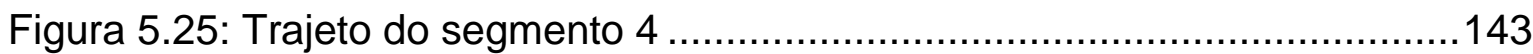

Figura 5.26: Pista totalemente deteriorada em uma das extremidades ..............143

Figura 5.27: Vegetação e terra invadindo a ciclovia..........................................143 
Figura 5.28: Trecho sem nenhuma sinalização 144

Figura 5.29: Posição da ciclovia ao lado da rodovia com acostamento estreito .144 Figura 5.30: Trecho com sinalização das bordas e ciclista empurrando a bicicleta 144

Figura 5.31: Má conservação e falta de sinalização em uma das extremidades 144

Figura 5.32: Trajeto do segmento 5 147

Figura 5.33: Vista geral da ciclofaixa posicionada ao lado direito da via 147

Figura 5.34: Sinalização em um cruzamento 147

Figura 5.35: Trajeto do segmento 6 150

Figura 5.36: Vista geral da ciclofaixa posicionada ao lado direito da via 151

Figura 5.37: Vista geral da ciclofaixa posicionada ao lado esquerdo da via 151

Figura 5.38: Sinalização no trecho de mudança de lado da ciclofaixa 151

Figura 5.39: Sinalização da ciclofaixa bastante deteriorada em uma esquina onde ocorre mudança de lado da mesma. 151

Figura 5.40: Sinalização típica nos cruzamentos 151

Figura 5.41: Trajeto do segmento 7 154

Figura 5.42: Vista geral da ciclofaixa posicionada ao lado direito da via 155

Figura 5.43: Vista geral da ciclofaixa posicionada ao lado esquerdo da via .......155

Figura 5.44: Sinalização no trecho de mudança de lado da ciclofaixa. 155

Figura 5.45: Ônibus circulando sobre a ciclofaixa junto ao terminal 155 

Tabela 2.1: Modos de transporte utilizados nas viagens urbanas (\%). .31

Tabela 2.2: Taxa de mortalidade em função do modo de transporte nos países da

União Europeia no biênio 2001 - 2002. 43

Tabela 2.3: Risco de sofrer lesão no trânsito x modo de transporte .43

Tabela 2.4: Vias e trechos do viário urbano com restrição às bicicletas .50

Tabela 2.5: Características de ciclovias .59

Tabela 2.6: Características de ciclofaixas. 62

Tabela 2.7: Relação entre inclinação da via e rampas máximas e normais. .65

Tabela 3.1: Dados gerais do município de Araraquara 71

Tabela 3.2: Valores do volume horário (bicicleta/hora) .78

Tabela 3.3: Valores do volume horário (bicicleta/hora) .83

Tabela 3.4: Valores do volume horário (bicicleta/hora) .88

Tabela 4.1: Dados gerais do município de São Carlos .....................................91

Tabela 4.2: Valores do volume horário (bicicleta/hora) ..................................97

Tabela 4.3: Valores do volume horário (bicicleta/hora) ................................101

Tabela 4.4: Valores do volume horário (bicicleta/hora) .................................106

Tabela 4.5: Valores do volume horário (bicicleta/hora) ..................................110

Tabela 4.6: Valores do volume horário (bicicleta/hora) .................................114

Tabela 4.7: Valores do volume horário (bicicleta/hora) .................................118

Tabela 4.8: Valores do volume horário (bicicleta/hora) ................................122

Tabela 5.1: Dados gerais do município de Rio Claro ....................................127

Tabela 5.2: Valores do volume horário (bicicleta/hora) .................................133

Tabela 5.3: Valores do volume horário (bicicleta/hora) ................................137

Tabela 5.4: Valores do volume horário (bicicleta/hora) ..................................141

Tabela 5.5: Valores do volume horário (bicicleta/hora) .................................145

Tabela 5.6: Valores do volume horário (bicicleta/hora) ...............................148

Tabela 5.7: Valores do volume horário (bicicleta/hora) ..................................152

Tabela 5.8: Valores do volume horário (bicicleta/hora) ................................156

Tabela 6.1: Índices associados aos três municípios ........................................161 



\section{SUMÁRIO}

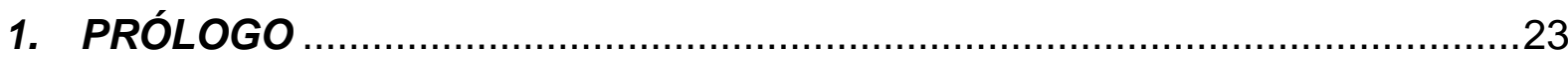

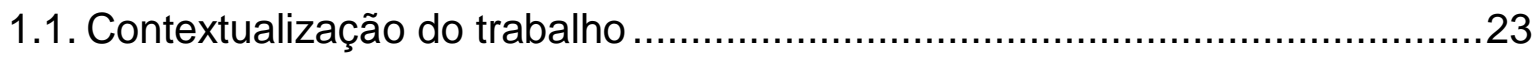

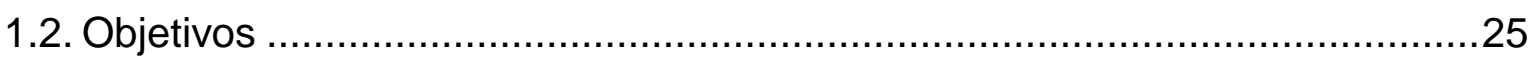

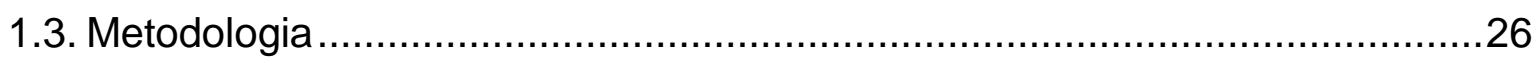

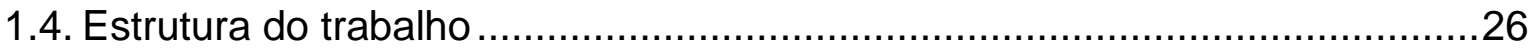

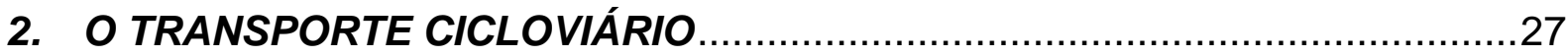

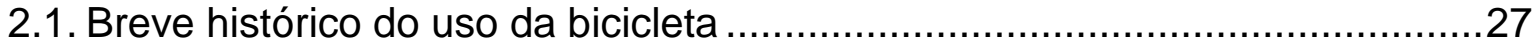

2.2. Sistema cicloviário em algumas cidades do mundo ...................................29

2.3. Sistema cicloviário em algumas cidades brasileiras .................................. 32

2.4. Vantagens intrínsecas ao uso da bicicleta .............................................. 38

2.5. Desvantagens intrínsecas ao uso da bicicleta.......................................... 42

2.6. Impactos no sistema viário e de trânsito .................................................46

2.7. Conceito de redes e integrações cicloviárias ...........................................50

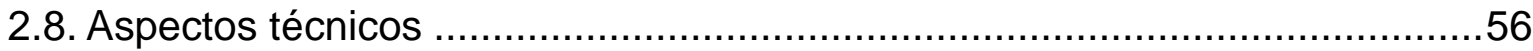

\section{CARACTERIZAÇÃO E AVALIAÇÃO DO SISTEMA CICLOVIÁRIO DE}

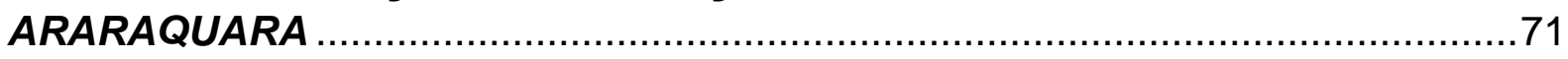

3.1. Informações gerais do município ............................................................ 71

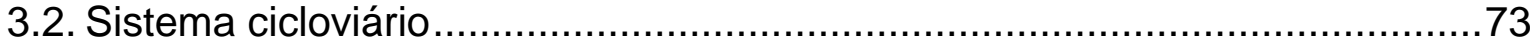

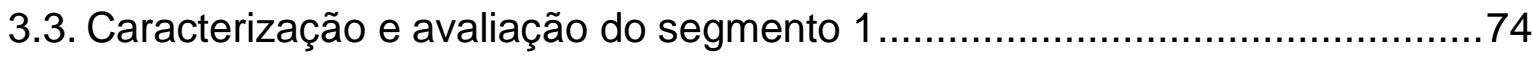

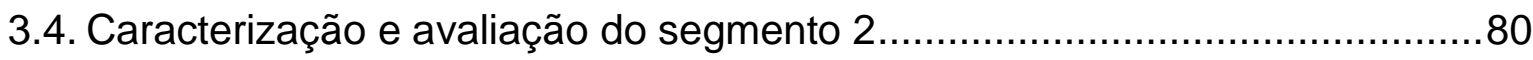

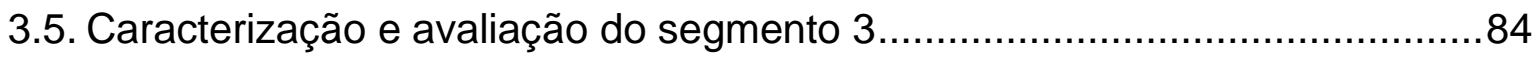

3.6. Avaliação geral do sistema cicloviário de Araraquara .................................89

4. CARACTERIZAÇÃO E AVALIAÇÃO DO SISTEMA CICLOVIÁRIO DE SÃO CARLOS 


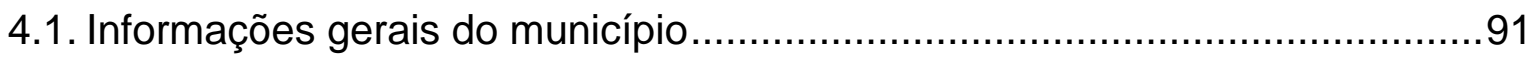

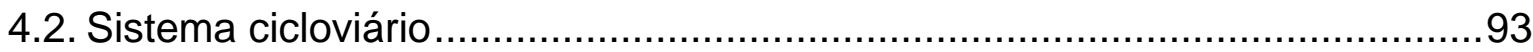

4.3. Caracterização e avaliação do segmento 1 ...................................................94

4.4. Caracterização e avaliação do segmento 2 ………...................................99

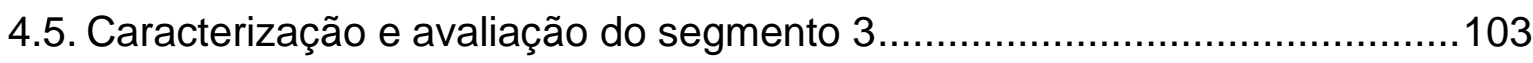

4.6. Caracterização e avaliação do segmento 4 ………………………..........108

4.7. Caracterização e avaliação do segmento 5 ..............................................112

4.8. Caracterização e avaliação do segmento 6 …………………………......116

4.9. Caracterização e avaliação do segmento 7 .................................................119

4.10. Avaliação geral do sistema cicloviário de São Carlos ...............................124

\section{CARACTERIZAÇÃO E AVALIAÇÃO DO SISTEMA CICLOVIÁRIO DE}

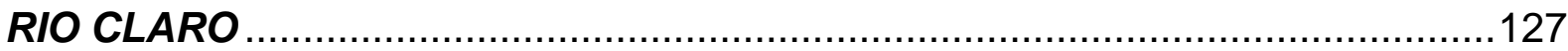

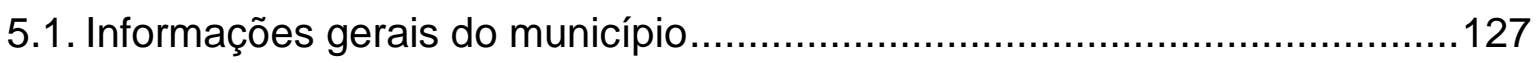

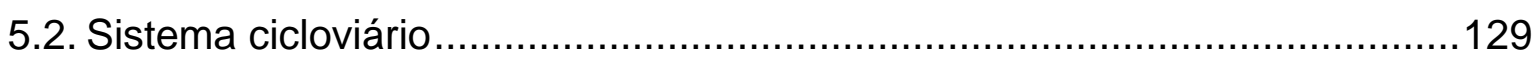

5.3. Caracterização e avaliação do segmento 1 ...............................................130

5.4. Caracterização e avaliação do segmento 2 ………………......................134

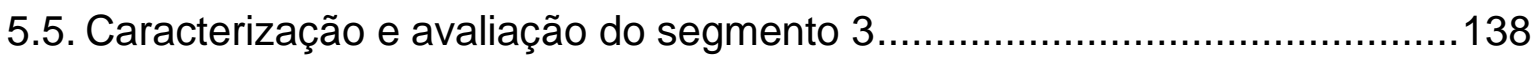

5.6. Caracterização e avaliação do segmento 4 ………………………….....142

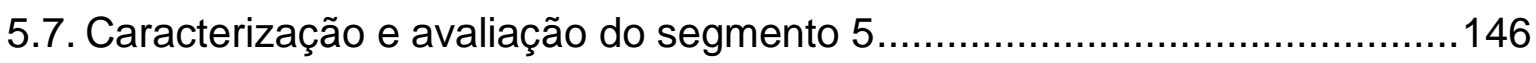

5.8. Caracterização e avaliação do segmento 6 ..............................................150

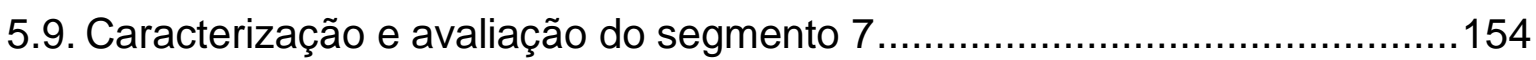

5.10. Avaliação geral do sistema cicloviário de Rio Claro .................................158

6. EPÍLOGO

6.1. Sobre as diferenças no uso do modo bicicleta ..........................................161

6.2. Sobre os tipos de segmentos cicloviários e a visão da população ................162

6.3. Sobre o impacto da bicicleta na fluidez do trânsito .......................................164

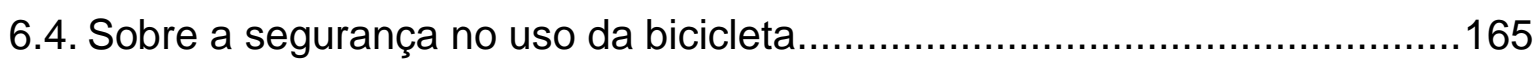

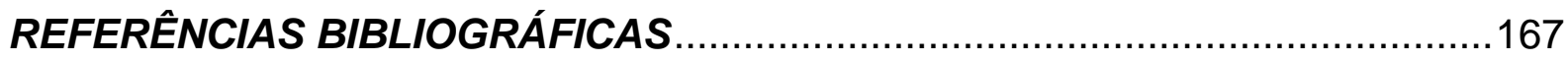

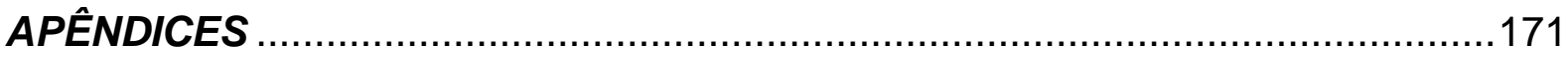




\section{1- PRÓLOGO}

ज

\subsection{Contextualização}

Nos países menos desenvolvidos, a bicicleta, em razão do baixo custo de aquisição e operação, tem grande participação no transporte urbano. Em muitas cidades dos países asiáticos e em Cuba (neste país, o custo da bicicleta é subsidiado e a compra financiada a longo prazo) o modo bicicleta chega a ser responsável por mais de $30 \%$ das viagens urbanas.

Alguns países desenvolvidos, como Holanda, Suécia, Dinamarca, Finlândia, etc., têm grande tradição no uso da bicicleta como modo de transporte urbano. Em algumas de suas cidades, as viagens realizadas por bicicleta também chegam a $30 \%$ ou mais do total de viagens.

Um veículo que pode ser considerado extensão da bicicleta é o triciclo (bicicleta de três rodas), que também é bastante utilizado em algumas cidades.

Os principais argumentos em prol do uso massivo da bicicleta são: baixo custo (o que é de grande relevância para os segmentos mais pobres), pouco espaço viário consumido (o que contribui para reduzir congestionamentos), benefício para a saúde (pedalar é um excelente exercício físico) e nenhum impacto ambiental negativo (não é poluente e não consome energia não renovável).

Por outro lado, há, também, muitos argumentos contrários ao uso da bicicleta: menor segurança no trânsito (o risco de se ferir ou morrer, em relação ao transporte por carro ou ônibus em viagens urbanas, é muito maior), desconforto (em razão do esforço físico e do suor), impossibilidade do uso em condições climáticas adversas (chuva, neve, etc.) e prejuízo ao trânsito (redução da largura da via no caso das ciclofaixas/ciclovias posicionadas na pista, velocidade baixa de circulação dos veículos quando atrás de bicicletas sem possibilidade de ultrapassagem e redução da capacidade das vias secundárias 
nos cruzamentos não semaforizados quando é grande o fluxo de bicicletas na via preferencial).

As principais formas de incentivo ao transporte por bicicletas (sobretudo por proporcionarem maior segurança) são: implantação de ciclovias (vias exclusivas para bicicletas), implantação de ciclofaixas nas vias comuns, implementação de estacionamentos dotados de dispositivos para prender as bicicletas (bicicletários), etc.

O Governo Federal do Brasil, por intermédio do Ministério das Cidades, tem destinado recursos para a implantação de ciclovias e ciclofaixas nas cidades do país. Por outro lado, uma pequena parcela da população adepta da bicicleta tem feito pressão para a implantação/expansão de sistemas cicloviários nas cidades de porte grande e médio.

No Estado de São Paulo, há cidades, como Sorocaba e a capital São Paulo, que têm expandido as suas ciclovias e ciclofaixas de uso por "necessidade" (viagens por motivo de trabalho, estudo, compras, etc.). Algumas cidades têm construído ciclovias para a prática de exercícios e de lazer em parques ou canteiros centrais largos de avenidas - que também se prestam ao deslocamento por "necessidade". No tocante às ciclovias/ciclofaixas de uso por "necessidade", observa-se que algumas cidades têm tido êxito ao expandir a sua infraestrutura cicloviária, uma vez que aumentou o número de usuários da bicicleta e os usuários efetivamente utilizam as ciclovias/ciclofaixas. É o caso, por exemplo, da cidade de Rio Claro. Em outras cidades, no entanto, isso não aconteceu: não houve aumento do número de ciclistas e, por razões diversas, os usuários da bicicleta preferem, em muitas situações, utilizar a via destinada ao tráfego geral e não a ciclovia/ciclofaixa que se encontra ao lado. É o que acontece, por exemplo, nas cidades de São Carlos e Araraquara.

Em vista do exposto, este trabalho tem o propósito de "descobrir" as razões da maior utilização do sistema cicloviário da cidade de Rio Claro e da baixa demanda de usuários nos sistema de Araraquara e São Carlos, visando obter informações que possam auxiliar no planejamento e no projeto da implantação de ciclovias e ciclofaixas nas cidades brasileiras. 
Na Figura 1.1 é mostrada a localização dos municípios de Araraquara, São Carlos e Rio Claro, todos situados no interior do Estado de São Paulo.

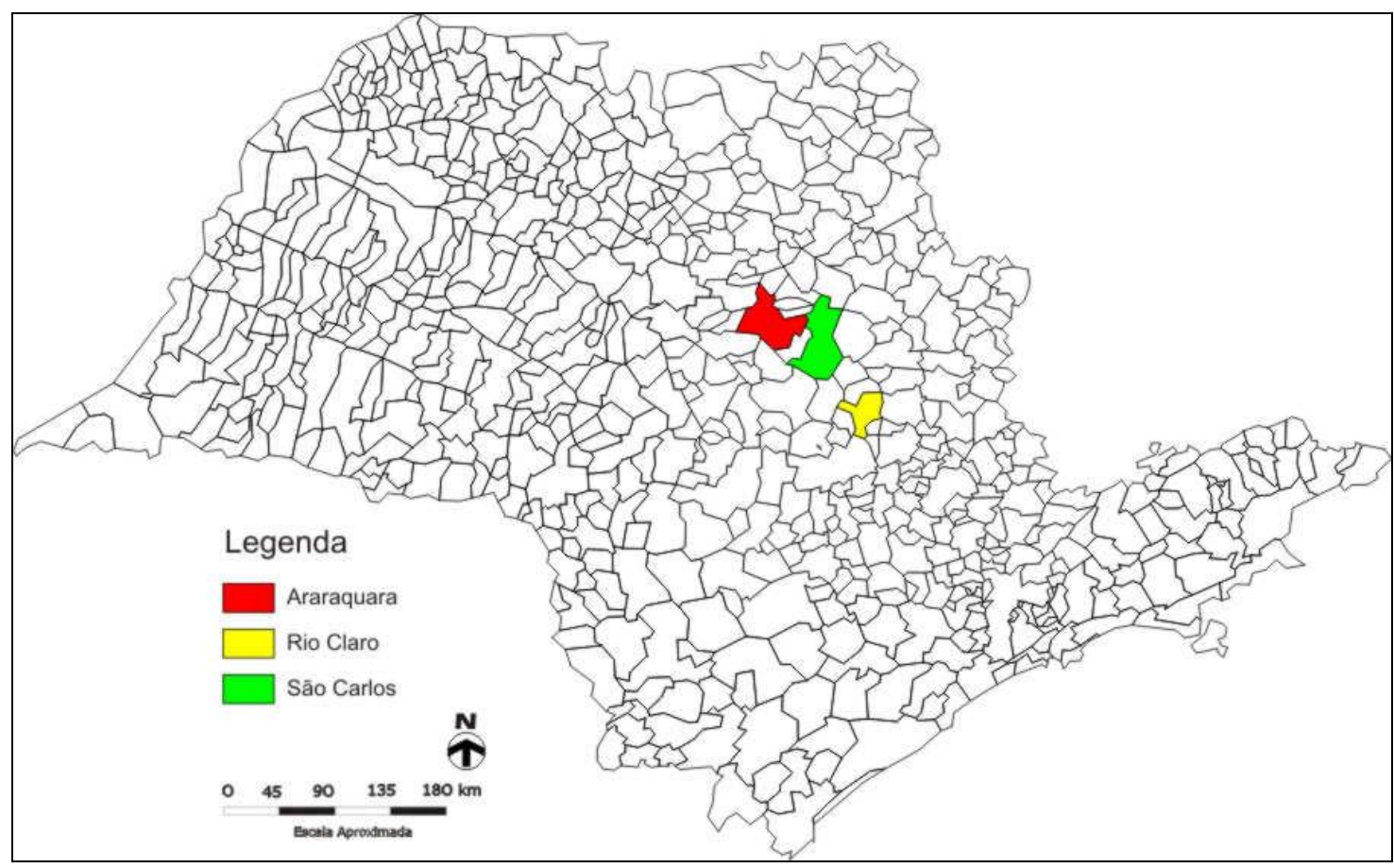

Figura 1.1 - Localização dos municípios das cidades estudadas. Fonte: Adaptado de IBGE, 2013.

\subsection{Objetivos}

Neste trabalho são investigadas as razões da maior utilização do sistema cicloviário na cidade de Rio Claro em relação à Araraquara e São Carlos, e descobrir os principais motivos da baixa demanda de usuários nas ciclovias e ciclofaixas das duas últimas cidades citadas. Esse objetivo visa compreender também o porquê da utilização ou não do espaço destinado ao tráfego de bicicletas. Tal objetivo auxilia na obtenção de informações que possam ajudar no planejamento e no projeto da implantação de ciclovias e ciclofaixas nas cidades brasileiras. 


\subsection{Metodologia}

Os seguintes procedimentos foram levados a efeito na consecução do trabalho:

- Pesquisa bibliográfica sobre o tema ciclovia/ciclofaixa e sistematização das informações.

- Levantamentos de campo e consulta a sites disponíveis na Internet para o mapeamento dos segmentos cicloviários (ciclovias e ciclofaixas) e obtenção das características técnicas dos mesmos.

- Pesquisas de campo do fluxo de bicicletas em cada segmento cicloviário (ciclovia/ciclofaixa) nos horários de maior movimento (de manhã, no meio do dia e à tarde).

- Entrevistas com ciclistas e moradores das vizinhanças da ciclovia/ciclofaixa.

- Processamento e análise das informações coletadas.

- Estabelecimento de fatos relevantes no contexto do trabalho.

\subsection{Estrutura do trabalho}

No primeiro capítulo são apresentados a contextualização, objetivos, metodologia e estrutura do trabalho.

O segundo capítulo contém uma revisão bibliográfica detalhada sobre o tema transporte cicloviário.

No capítulo três é apresentada a caracterização e avaliação do sistema cicloviário da cidade de Araraquara; no capítulo quatro, de São Carlos e, no capítulo cinco, de Rio Claro.

No capítulo seis são apresentados pontos relevantes no contexto do trabalho.

Por último, são apresentadas as referências bibliográficas. 


\section{2- TRANSPORTE CICLOVIÁRIO}

부

\subsection{Breve histórico do uso da bicicleta}

A bicicleta - do latim bi (dois) e do grego kyklos (rodas) -, teve seu primeiro projeto, tal como conhecemos hoje, entre os anos de 1490 e 1500 por meio de croquis esquemáticos de Leonardo da Vinci. Esses desenhos, que só foram descobertos muitos séculos depois, mais precisamente em 1966 por monges italianos, demostravam conceitos de mecânica com sistema de direção e transmissão por corrente. (http://byketripdasgerais.blogspot.com.br).

O desenvolvimento e o aperfeiçoamento da bicicleta como meio de locomoção foi progredindo através dos séculos e entre as décadas de 1790 e 1820, teve sua gênese formada. A bicicleta idealizada inicialmente por Conde Sivrac e intitulada de Celerífer em 1790, era um veículo primitivo de duas rodas ligadas por uma ponte de madeira em forma de cavalo e acionado por impulso alternado dos pés sobre o chão, como mostrado na Figura 2.1.

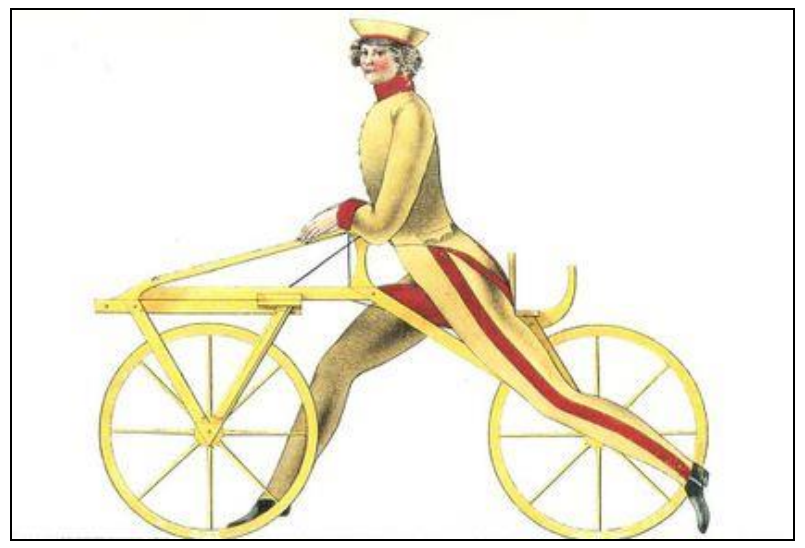

Figura 2.1 - Celerífer. Fonte: Amobike, 2012.

Posteriormente, em 1817, o alemão Barão Karl von Drais, Engenheiro Agrônomo e Florestal, instalou no Celerífer, já desenvolvido anteriormente, um sistema de direção livre que permitia aos usuários realizar curvas e, dessa 
forma, manter o equilíbrio da bicicleta e ao mesmo tempo realizar manobras de livre arbítrio quando em movimento. Além do mais, a "draisiana", como foi nomeada, possuía um rudimentar sistema de freios e um ajuste de altura do selim para facilitar o seu uso por pessoas de diversas estaturas. Mesmo com os inúmeros avanços tecnológicos para o aperfeiçoamento de novos componentes, o conceito e o princípio básico do Celerífer e da Draisiana perduram até hoje, evidenciando a bicicleta como um meio de transporte simples e eficaz.

Com o passar das décadas não foram só as bicicletas que passaram por avanços tecnológicos e melhorias em seu funcionamento, houve também progresso na infraestrutura para a circulação das mesmas, visto que a necessidade para tal atividade foi aos poucos ganhando espaço nas cidades. Desde sua introdução no início do século XX, em território nacional, a bicicleta teve boa aceitação, sendo bastante utilizada pela classe operária e prestadores de serviços. Embora tenha inicialmente obtido êxito, a bicicleta, como meio de transporte, teve a sua utilização diminuída, pois com programas de incentivo ao transporte rodoviário no final da década de 50 e a produção massiva de automóveis e ônibus, a bicicleta foi perdendo espaço e notoriedade como meio de locomoção urbana. Seu uso ganhou espaço novamente na década de 70 , com a crise do petróleo e o crescente aumento populacional. Além do mais, a atratividade da bicicleta tornou-se mais evidente devido ser uma alternativa de locomoção a baixo custo e acessível a todos.

Diante disso, muitas cidades, tanto no Brasil como no mundo, propuseram estudos de viabilidade e planos diretores para melhorar e estruturar racionalmente espaços cicloviários, almejando garantir a mobilidade e segurança aos ciclistas. O Brasil, no entanto, não possui uma cultura do uso massivo desse meio de transporte, diferente dos países da Europa, onde o transporte por bicicleta vem proliferando como uma excelente alternativa de locomoção nas cidades. 


\subsection{Sistema cicloviário em algumas cidades do mundo}

Muitos países vêm adotando e implementando políticas de incentivo ao uso da bicicleta, e consequentemente infraestrutura para tal, a fim de objetivar, como estratégia, um transporte urbano mais sustentável e menos impactante na mobilidade urbana. Além do mais, a utilização da bicicleta como meio de transporte surge como solução frente às políticas de valorização do espaço urbano e da melhoria da qualidade de vida. Nesse sentido, países da Europa vêm estruturando planos e estratégias para a inserção da bicicleta no cotidiano da mobilidade urbana da população.

São referências no assunto cidades como Amsterdam, Paris, Copenhague e Berlim. Essas cidades tiveram um aumento considerável na utilização da bicicleta, desde a década de 80 .

Em Amsterdam, capital da Holanda, por exemplo, 20\% dos deslocamentos são feitos por bicicletas (Pires, 2008). É um número considerável, levando-se em conta o tamanho da cidade e a população local. São mais de dezesseis mil quilômetros de infraestrutura cicloviária em estradas e mais de dezoito mil quilômetros nas cidades. Os números dessa cidade europeia, em se tratando de sistema viário e suas consequentes variáveis, vão além do comumente observado. Em Amsterdam, $75 \%$ dos seus habitantes possuem uma bicicleta e mais de $50 \%$ a utilizam como meio de transporte diário. Além disso, a cidade conta com uma infraestrutura cicloviária totalmente sinalizada, com sistema de semaforização especial e sinais de rotas. Existe também a integração com outros meios de transportes em estações de metrô, trem e transporte coletivo por ônibus.

Para que Amsterdam chegasse nesse estágio, os planejadores e profissionais da área utilizaram de estratégias para incentivar o uso da bicicleta, favorecendo primeiramente a mobilidade dos pedestres e consequentemente de bicicletas no centro da cidade. Dessa forma, o automóvel teve grandes limitações de chegar ao centro, o que resultou no fim dos grandes congestionamentos e de um espaço urbano mais igualitário, democrático e humano. 
Vale ainda frisar, como comparativo em relação à situação brasileira, que a Holanda é um dos menores países da Europa, menos do dobro do Estado do Sergipe, que é um dos menores do Brasil ${ }^{1}$, e, em contrapartida, o território nacional é o quinto maior do mundo, mas possui apenas pouco mais de dois mil quilômetros de ciclovias.

A Alemanha possui infraestrutura não só nas cidades, cuja extensão da rede ultrapassa os 1800 quilômetros de ciclovias e ciclofaixas, mas também em rodovias. Ligando Dussedorf a Duisburgo, encontram-se sessenta quilômetros de asfalto exclusivos para ciclistas, o que revela um grande avanço em termos de mobilidade e opção de meio de transporte. Em Berlim, por exemplo, são 775 quilômetros de ciclovias, o que revela a importância da bicicleta como veículo locomoção para a capital alemã. Além do mais, a cidade conta com cerca de 500 mil ciclistas, que são responsáveis por $13 \%$ do tráfego urbano ${ }^{2}$.

No continente americano, cidades como Portland, Nova lorque, Bogotá, Guadalajara, Rio de Janeiro entre outras, estão trabalhando fortemente para incentivar o uso da bicicleta como meio de transporte.

Em Portland e Nova lorque, o processo de estruturação cicloviária vem acontecendo incisivamente nos últimos anos. Na primeira, por exemplo, foi estruturado em 1996 um Plano Cicloviário com o objetivo de implantar redes de ciclovias e condições seguras de estacionamento, além da divulgação do uso da bicicleta através de campanhas promocionais. No total são mais de 480 quilômetros de uma extensa malha cicloviária cobrindo quase toda a cidade, cujos deslocamentos diários chegam aos $9 \%$ da população residente. Além do mais, a cidade conta com uma série de políticas urbanas que tornam o trânsito de bicicletas bastante seguro (Bicycle Resources, 2000; Bureau of Planning and Sustainability, 2011).

Em Nova lorque, o sistema cicloviário já ultrapassou os 410 quilômetros. Além disso, o mote tem sido forte no que diz respeito ao aluguel de bicicletas. Muitos cidadãos nova-iorquinos utilizam desse recurso para se deslocarem pela

\footnotetext{
${ }^{1}$ Fonte: IBGE, 2012.

${ }^{2}$ Fonte: http://thebicyclesite.com, 2013.
} 
cidade, pagando uma taxa e usufruindo de forma mais saudável o espaço urbano ${ }^{3}$.

Na América Latina, mais precisamente em Bogotá, Colômbia, o sistema cicloviário iniciado em 2009 conta hoje com mais 350 quilômetros de ciclovias, o que torna a mesma a cidade com a mais ampla rede cicloviária da América Latina. Em Bogotá, aproximadamente $6 \%$ das viagens diárias são realizadas por bicicletas, ou seja, valores entre 300 mil e 400 mil viagens (Portal Mobilize, 2012; Sustainable Cities, 2013).

$\mathrm{Na}$ Tabela 2.1 e na Figura 2.2, são mostradas, respectivamente, a porcentagem das viagens urbanas por modos em diferentes cidades da Europa e da América do Norte e a extensão cicloviária em algumas cidades do mundo.

Tabela 2.1 - Modos de transporte utilizados nas viagens urbanas (\%). Fonte: International Bicycle Fund, 1999.

\begin{tabular}{cccccc}
\hline \multicolumn{7}{c}{ Modo de Transporte } \\
\hline País & Bicicleta & A pé & Transporte Coletivo & Carro & Outros \\
Holanda & 30 & 18 & 3 & 45 & 2 \\
Dinamarca & 20 & 21 & 14 & 42 & 3 \\
Alemanha & 12 & 22 & 16 & 49 & 1 \\
Suíça & 10 & 29 & 20 & 38 & 1 \\
Suécia & 10 & 39 & 11 & 36 & 4 \\
Áustria & 9 & 31 & 13 & 39 & 8 \\
Inglaterra & 8 & 12 & 14 & 62 & 4 \\
França & 5 & 30 & 12 & 47 & 6 \\
Itália & 5 & 28 & 16 & 42 & 9 \\
Canadá & 1 & 10 & 14 & 74 & 1 \\
Estados Unidos & 1 & 9 & 3 & 84 & 3 \\
\hline
\end{tabular}

\footnotetext{
${ }^{3}$ Fonte: http://www.euvoudebike.com
} 


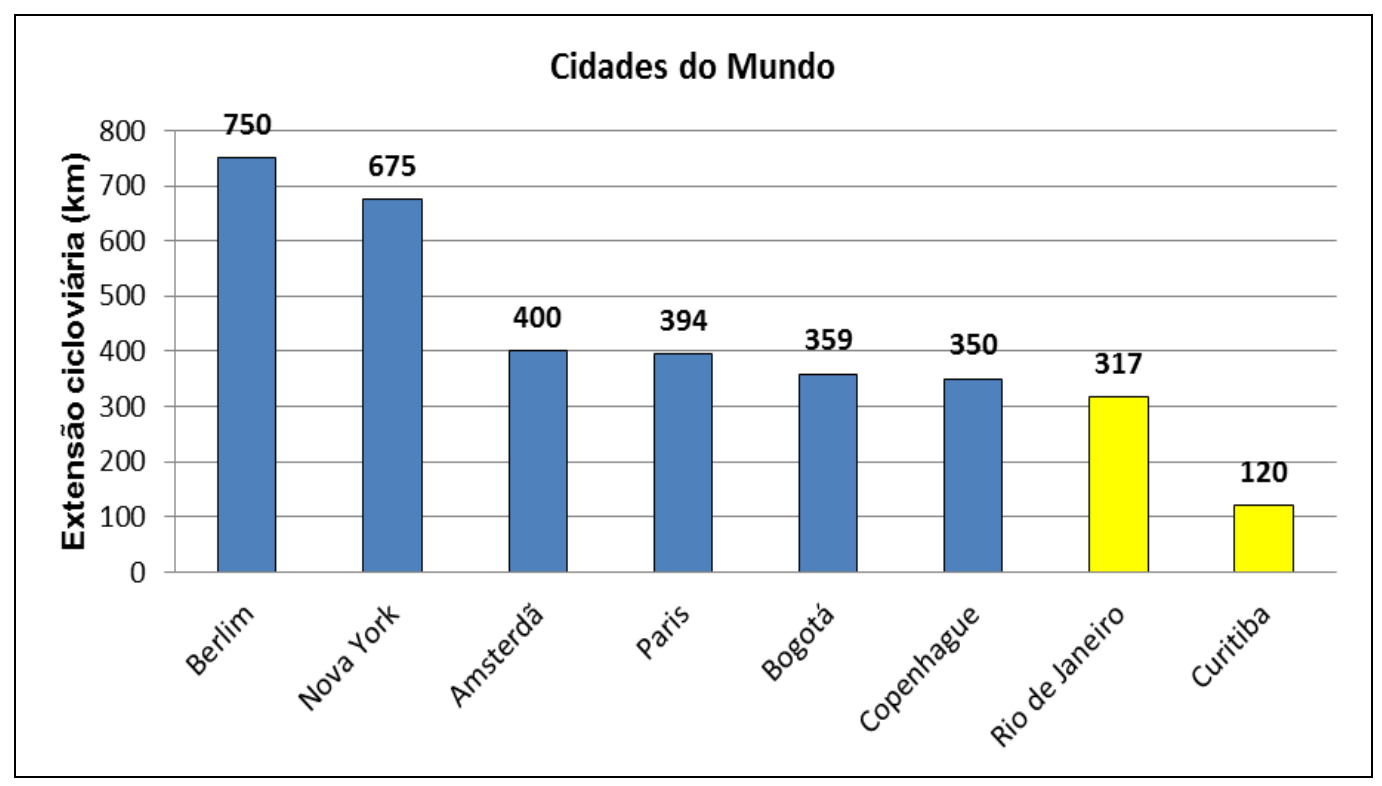

Figura 2.2 - Extensão cicloviária em algumas cidades do mundo. Fonte: Adaptado de Portal Mobilize, 2012.

\subsection{Sistema cicloviário em algumas cidades brasileiras}

Inicialmente, é importante destacar que, nos últimos anos, houve, no país, importantes avanços no que diz respeito ao modo de transporte por bicicleta. Vale dizer, primeiramente, que o Código de Trânsito Brasileiro (CTB) reconhece como legítima a presença da bicicleta como elemento do trânsito no território nacional e regulamenta sua devida utilização.

Art. 58. Nas vias urbanas e nas rurais de pista dupla, a circulação de bicicletas deverá ocorrer, quando não houver ciclovia, ciclofaixa, ou acostamento, ou quando não for possível a utilização destes, nos bordos da pista de rolamento, no mesmo sentido de circulação regulamentado para a via, com preferência sobre os veículos automotores (CTB, Lei № 9.503, de 23 de setembro de 1997).

O Brasil, em comparação com outros países que apresentam planos e redes cicloviárias já estruturados, ainda percorre seus primeiros passos, de forma tímida, aleatória e pontual. Cidades como Rio de Janeiro - cidade com maior malha cicloviária -, Florianópolis, Sorocaba, Aracajú, Brasília, Belo Horizonte, Porto Alegre e Curitiba, estão iniciando o processo de utilização da bicicleta como meio de transporte. 
Segundo o Ministério das Cidades (2007), o país já contava, na ocasião, com aproximadamente 2.505 quilômetros de infraestrutura cicloviária (ciclovias, ciclofaixas e vias preferenciais para bicicletas), o que não era possível apontar no final dos anos 90, onde a malha cicloviária não ultrapassava os 250 quilômetros e restringia-se a pouco mais de cinquenta cidades.

A Figura 2.3 mostra alguns números sobre a extensão da rede cicloviária brasileira em passado recente.

\begin{tabular}{|c|c|c|c|c|}
\hline $\begin{array}{l}\text { Dimensão } \\
\text { populacional } \\
\text { dos municípios } \\
\text { por número de } \\
\text { habitantesi }^{\text {intal }}\end{array}$ & $\begin{array}{l}\text { Número de } \\
\text { municípiosii }\end{array}$ & $\begin{array}{r}\text { Número de } \\
\text { municípios com } \\
\text { infraestrutura } \\
\text { cicloviáriaiii }\end{array}$ & $\begin{array}{r}\text { Porcentagem } \\
\text { dos municípios } \\
\text { com alguma } \\
\text { infraestrutura } \\
\text { cicloviária }\end{array}$ & $\begin{array}{r}\text { Extensão } \\
\text { de ciclovias } \\
\text { em kmiii }\end{array}$ \\
\hline > 1 milhão & 14 & 12 & $86 \%$ & 483,40 \\
\hline $\begin{array}{l}\text { De } 500 \text { mil a } \\
1 \text { milhão }\end{array}$ & 22 & 16 & $73 \%$ & 204,50 \\
\hline De 250 a 500 mil & 62 & 37 & $60 \%$ & 486,11 \\
\hline De 100 a 250 mil & 156 & 106 & $68 \%$ & 867,01 \\
\hline De 60 a 100 mil & 222 & 108 & $49 \%$ & 467,85 \\
\hline Total & 476 & 279 & $59 \%$ & $2.505,87$ \\
\hline
\end{tabular}

Figura 2.3 - Total de municípios e extensão de quilômetros de ciclovias por dimensão populacional de municípios brasileiros maiores que 60 mil habitantes.

Fonte: Instituto de Energia e Meio Ambiente, 2009.

Em julho de 2001, a Empresa Brasileira de Planejamento de Transportes Geipot publicou um relatório intitulado "Planejamento Cicloviário: Diagnóstico Nacional". Esse relatório, que serviu de base para um futuro manual, compila dados e levantamentos da utilização da bicicleta como meio de transporte no Brasil. Trata-se de um documento inicial sobre um assunto que aborda aspectos técnicos, estatísticos e de infraestrutura para o fomento de futuros planos cicloviários. 
Em meados de 2004, com o objetivo de criar uma política, até então nova em sua concepção, para o transporte cicloviário, foi lançado o Programa Brasileiro de Mobilidade por Bicicleta (Bicicleta Brasil). Esse plano visava oferecer auxílio e suporte, tanto técnico quanto operacional, para que os municípios implantassem um Plano Cicloviário, coeso, racional e que possivelmente dialogasse com demais modos de transporte (intermodalidade), formando assim, uma rede planejada e estruturada. Ministério das Cidades, 2007.

A partir de então, diversas ações foram e estão sendo feitas para dar suporte e nortear a questão do transporte cicloviário. No que diz respeito a essa problemática, o Instituto de Energia e Meio Ambiente - IEMA (2010) formula que um Plano Cicloviário deve ser composto por: planejamento, implantação e gestão do sistema, incluindo programas de educação e informação voltados ao estímulo do uso deste meio não motorizado.

Também nessa linha, em 2007 foi lançado o Plano de Mobilidade (PlanMob), como referência norteadora para elaboração dos Planos Diretores de Transporte e da Mobilidade. Dentre as diversas diretrizes que o Plano indica, algumas delas são relacionadas ao transporte cicloviário, como:

- a valorização da bicicleta procurando integrá-la aos modos de transporte coletivo;

- inserir e ampliar o transporte por bicicleta na matriz de deslocamentos urbanos;

- promover sua integração aos sistemas de transportes coletivos, visando reduzir o custo de deslocamento, principalmente da população de menor renda;

- estimular os governos municipais a implantar sistemas cicloviários e um conjunto de ações que garantam a segurança de ciclistas nos deslocamentos urbanos;

- difundir o conceito de mobilidade urbana sustentável, estimulando os meios não motorizados de transporte, inserindo-os no desenho urbano. (SEMOB, 2007). 
Mais recentemente, outra importante medida foi a promulgação da Lei Federal no 12.587/2012, instituindo a Política Nacional de Mobilidade Urbana, tendo como uma das principais diretrizes a priorização dos modais não motorizados e a dos transportes públicos sobre os individuais motorizados.

Também cabe destacar que, com a criação do Ministério das Cidades, em 2001, passou a haver uma maior disponibilidade de recursos para o transporte cicloviário.

O fato é que, nas últimas décadas o país sofreu significativas mudanças em relação ao processo de estruturação urbana, em específico para as questões da mobilidade por bicicletas e muitos planos surgiram para oferecer consistência e tenacidade para esse meio de transporte tão importante.

Mesmo com os importantes avanços políticos no tocante às leis e aos planos para o transporte cicloviário, são poucas as cidades brasileiras que possuem planos adequados e infraestruturas cicloviárias. A bicicleta como meio de transporte é muito utilizada em cidades pequenas e em algumas cidades médias. Nas grandes cidades, onde o transporte motorizado é massivo, a bicicleta ainda é um meio de locomoção pouco difundido, por conta da falta de infraestrutura e espaço específico para a sua circulação. O que se encontra nessas grandes cidades, são ciclovias e/ou ciclofaixas interligando parques e jardins, principalmente em dias de final de semana ou feriado, sendo o uso restrito ao lazer.

As Figuras 2.4 e 2.5 mostram, respectivamente, a divisão modal no Brasil e em cidades entre 250 mil e 500 mil habitantes.

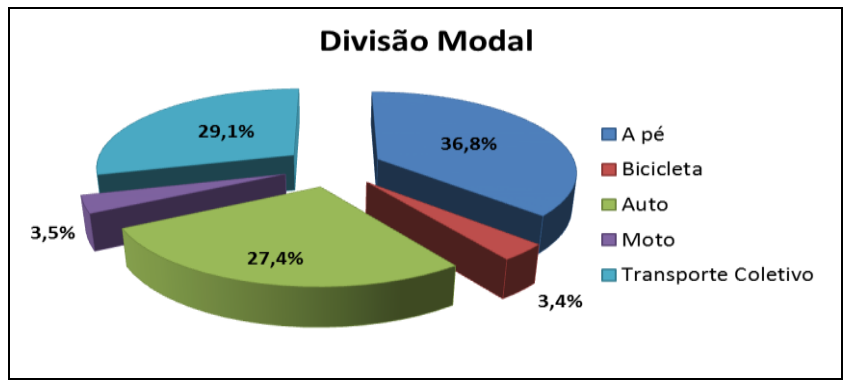

Figura 2.4 - Divisão modal no Brasil.

Fonte: Adaptado de ANTP, 2011. 


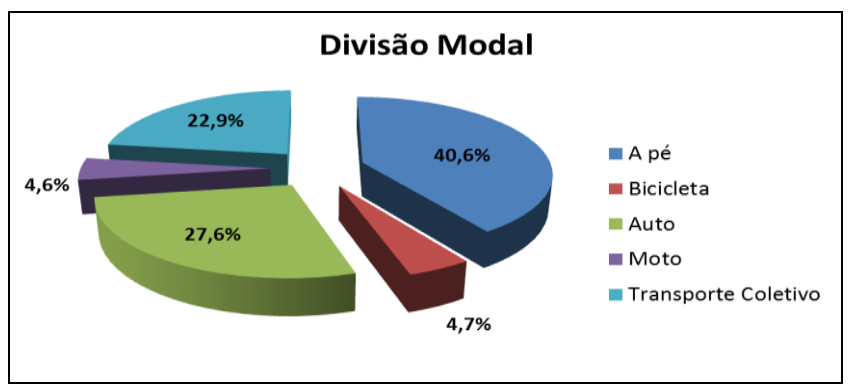

Figura 2.5 - Divisão modal entre cidade entre 250 mil e 500 mil habitantes. Fonte: Adaptado de ANTP, 2011.

Embora haja diversos estudos e tentativas para se obter a equidade de espaço nas vias com a inserção da bicicleta como meio de transporte e suas necessidades intrínsecas, a mudança ou quebra de paradigmas - como a prioridade de meios motorizados individuais e pesados investimentos de infraestrutura para tal -, se apresenta como um grande desafio, que deve abranger um longo processo de transformação social e política, além de hábitos adquiridos pela população.

Entre as políticas setoriais urbanas, a mobilidade é aquela onde os resultados aparecem em menor prazo, porém, são quase sempre as mais polêmicas, por envolver todos os cidadãos de forma direta e cotidiana. No caso específico do paradigma do transporte individual, esbarra-se no mote do consumismo e na imagem do automóvel como objeto de desejo e "status" social. Porém, o pressuposto norteador deve ser de que a cidade, como ambiente de uso coletivo, deve, no que tange o transporte, dividir democraticamente o sistema viário entre os diversos meios: o pedestre, em qualquer condição individual de mobilidade; o ciclista; os veículos coletivos e; o transporte individual motorizado.

Nesse contexto muitas cidades do Brasil têm trabalhado nessa linha, a fim de melhor dividir o espaço urbano entre os diversos modos de transporte e principalmente oferecer suporte aos usuários de transporte não motorizados.

Atualmente o Rio de Janeiro conta com cerca de 320 quilômetros de ciclovias, dos quais 150 quilômetros de pistas são à beira-mar, ou seja, consideradas como "de lazer". Esses números atuais são suficientes para dar à cidade o status de segunda maior rede de ciclovias da América Latina, atrás apenas de 
Bogotá, na Colômbia. Além disso, a cidade conta um eficaz sistema de aluguel de bicicletas (gratuito na primeira meia hora) intitulado de Solução Alternativa de Mobilidade por Bicicleta — SAMBA. Essa iniciativa, que surgiu em 2008, faz parte de um projeto municipal mais amplo de planejamento cicloviário chamado "Pedala Rio".

O sistema conta com dezenove estações concentradas na zona sul da cidade, tendo como objetivo, a integração da bicicleta com outros meios de transporte como: ônibus, trem e metrô. Segundo a prefeitura municipal do Rio de Janeiro, essa alternativa atraiu um número considerável de usuários, contabilizando 1,8 milhão de viagens, mais de 150 mil usuários cadastrados e atingindo uma média superior a quatro mil viagens por dia.

Outra grande referência no assunto é a cidade de Sorocaba no interior do Estado de São Paulo. Sua infraestrutura cicloviária é modelo de eficácia e planejamento. A cidade possui a maior rede de ciclovias do Estado, tendo um total de 106 quilômetros de extensão, dos quais, 103 quilômetros são separados fisicamente das vias destinadas aos veículos. Além do mais, Sorocaba possui o menor índice de acidentes envolvendo ciclistas. Isso prova que é possível estruturar planos cicloviários e ainda garantir segurança aos seus usuários

Outros relevantes exemplos estão em Porto Alegre, no Rio Grande do Sul, com atuais oito quilômetros de ciclovias, mas com um Plano Diretor Cicloviário de 495 quilômetros; Brasília com cerca de 50 quilômetros e um programa de 610 quilômetros de ciclovias; Belo Horizonte com 20 quilômetros cicloviários e com uma previsão de mais 20 quilômetros em curto prazo, além de um Plano de Mobilidade que contempla mais de 250 quilômetros de ciclovias; Curitiba que já possui aproximadamente 120 quilômetros de ciclovias e ciclofaixas, todos com o princípio de ligação entre os parques; São Paulo com aproximadamente 70 quilômetros de sistema cicloviário, contabilizando ciclovias, ciclofaixas e ciclorrotas e Aracajú que oferece aos ciclistas 56 quilômetros de ciclovias. $\mathrm{Na}$ Figura 2.6 estão indicadas as extensões cicloviárias de algumas cidades brasileiras. 


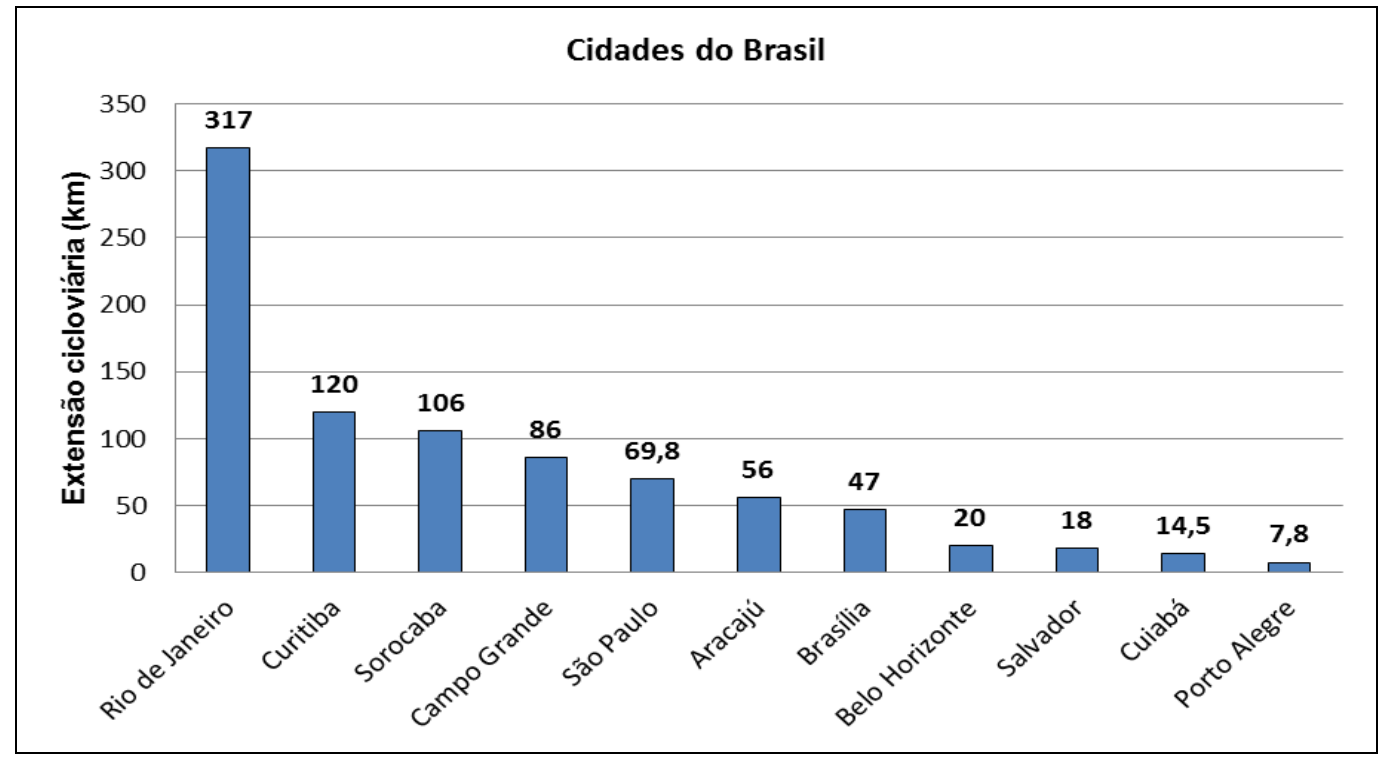

Figura 2.6 - Extensão cicloviária em algumas cidades do Brasil.

Fonte: Adaptado de Portal Mobilize, 2012.

\subsection{Vantagens intrínsecas ao uso da bicicleta}

Segundo Gondim (2010), a bicicleta permite a realização de viagens mais longas. Sendo um transporte barato, é acessível a toda a população, oferecendo maior mobilidade às pessoas de baixa renda que precisam utilizar transporte público para suas necessidades de deslocamento. É um transporte não poluente e que ocupa pequeno espaço na rede viária. Tem ainda a característica de ser um veículo apreciado para o esporte e o lazer.

Guimarães (1989), delineando as características favoráveis ao uso delas como meio de transporte, reforça as qualidades com os seguintes argumentos:

- O uso da bicicleta significa economia de divisas, visto que esta modalidade é energicamente mais eficiente em relação às outras, além de o custo de aquisição e manutenção dos veículos ser o que mais se enquadra nos orçamentos da maioria da população;

- Exige pouco espaço para estacionamento - numa vaga para automóveis cabem 10 bicicletas; 
- O pouco espaço requerido e o reduzido peso das bicicletas tornam-na de grande flexibilidade, sendo que os investimentos na construção de infraestrutura exigida e os custos de manutenção são baixos;

- Permite uma maior participação na vida da cidade em relação aos automóveis, admitindo maior identificação com paisagens e entorno imediato, permitindo que o ciclista tenha uma atitude de trânsito mais comunicativa e menos agressiva.

O uso da bicicleta nas cidades é de caráter prático, devido ao seu tamanho e sua facilidade de deslocamento em áreas congestionadas, sendo uma boa opção de transporte que otimiza o acesso e a mobilidade. Além do mais, andar de bicicleta ajuda fisicamente o usuário, pois evita o sedentarismo e é economicamente acessível a todos.

Em deslocamentos de até cinco quilômetros, além de muito eficiente, a bicicleta possui flexibilidade quase igual à de um pedestre, mas com velocidade muito superior, equiparável à de um automóvel (considerando-se, naturalmente, as condições de tráfego nos grandes centros urbanos). A Figura 2.7 ilustra essas informações.

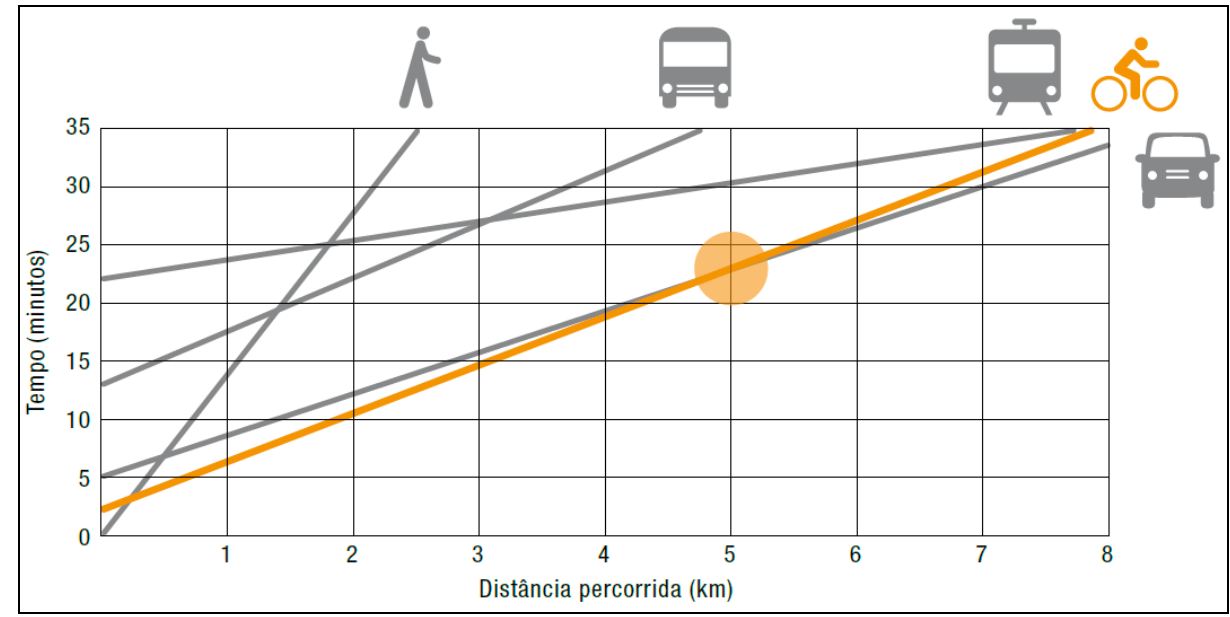

Figura 2.7 - Deslocamento porta a porta.

Fonte: Instituto de Energia e Meio Ambiente, 2010.

Segundo o IEMA (2010) a implantação de uma malha cicloviária e demais infraestruturas para a bicicleta possibilita a circulação dos usuários com conforto e segurança, itens relevantes e intrínsecos ao planejamento 
cicloviário. Além disso, por meio dessas premissas a bicicleta passa a competir com o automóvel em deslocamentos de até 5 quilômetros, como já referido, e possibilita ao ciclista a utilização da mesma para viagens mais longas, superando o carro em caso de congestionamentos.

Outra importante e estratégica vantagem do uso da bicicleta como meio de transporte é a facilidade de integração com diferentes meios de transporte público. Esse excelente atributo possibilita uma maior agilidade nos deslocamentos, podendo ser realizados de formas distintas:

- Instalação de paraciclos e bicicletários nas proximidades das estações ou pontos de embarque de trem, metrô e ônibus;

- Possibilidade embarque e desembarque ou a instalação de dispositivos para transportar bicicletas nos ônibus ou metrô;

- Aluguel de bicicletas em locais públicos, ajudando na mobilidade e na circulação das pessoas nos centros urbanos.

Segundo Geipot (2001b) a utilização da bicicleta como meio de locomoção, traz benefícios em relação ao baixo custo de aquisição e manutenção; baixa perturbação ambiental; contribuição à saúde do usuário; equidade (uma vez que a bicicleta é o veículo individual que mais atende o princípio da igualdade social, pois proporciona um alto grau de autonomia à população como um todo); flexibilidade (o usuário possui uma tomada de decisão mais livre quanto aos horários, às rotas e a outros modos de transportes); rapidez e menor necessidade de espaço público.

Analisando este último item, - menor necessidade de espaço público -, de forma prática, o Geipot (2001b) informa que em uma hora passam até 1.500 bicicletas por metro de largura de via. Dessa forma, uma faixa de 3 metros comporta um fluxo de cerca de 4.500 bicicletas, enquanto permite a passagem de apenas 450 automóveis, aproximadamente.

De forma geral, o modo de transporte por bicicleta apresenta as seguintes principais vantagens para os usuários: 
- Total liberdade na escolha do horário de saída;

- Total liberdade na escolha do percurso;

- Viagem de porta a porta;

- Muitas vezes, menor tempo total de viagem, devido à maior velocidade, menor percurso e menor distância de caminhada;

- Viagem direta, sem necessidade de transbordo;

- Possibilidade de transportar pequenos volumes de carga, ou mesmo outra pessoa;

- Possibilidade de fazer paradas intermediárias durante a viagem para realizar outras atividades;

- Não necessidade de espera pelo veículo de transporte;

- Custo de aquisição muito baixo;

- Custo de manutenção baixíssimo;

- Nenhum custo de operação;

- Possibilidade de parada em praticamente qualquer lugar;

- Não necessidade de pagar pedágio e estacionamento;

- Benefício para a saúde, pois pedalar é um excelente exercício físico;

- Facilidade de integração ao transporte público, evitando grandes percursos a pé.

No que diz respeito à sociedade, o modo de transporte cicloviário apresenta as seguintes principais vantagens:

- Não poluição atmosférica e sonora.

- Não consumo de energia. 
- Menor ocupação de espaço viário em relação ao carro (não em relação ao ônibus), o que pode contribuir para reduzir os congestionamentos e a necessidade de investimentos em infraestrutura viária, incluindo vias e estacionamentos.

- Contribuição para a humanização da cidade (facilita a interação entre as pessoas).

- Possibilidade de integração do ciclista ao sistema de transporte público.

\subsection{Desvantagens intrínsecas ao uso da bicicleta}

Assim, como existem vantagens na utilização da bicicleta como meio de transporte, existem também suas desvantagens, afinal, todo meio de transporte possui características intrínsecas a sua função, sendo elas positivas ou negativas, podendo variar conforme determinado fim.

Como desvantagens, o uso da bicicleta gera vulnerabilidade quanto aos furtos, principalmente em lugares onde não há estacionamentos adequados, e isso gera insegurança por parte dos usuários. Outro fator limitador ao uso da bicicleta é a exposição às intempéries e à poluição, que influenciam muito na tomada de decisão de cada ciclista. Hoje, em cidades com domínio massivo de veículos motorizados, o fator segurança é mais latente que impede 0 deslocamento mais significativo de bicicletas em nossas cidades.

Sobre isso, Ferraz (2012) coloca que o risco de acidentes envolvendo os diversos tipos de veículos segue, em geral, a seguinte ordem (maior para menor): motocicleta-bicicleta-pedestre-carro-ônibus/caminhão. Segundo (Elvik \& Vaa, 2004 apud Ferraz, 2012), na Noruega, a taxa de acidentes por quilômetro para pedestres é de 4 a 6 vezes maior do que a dos ocupantes de carro; e de ciclistas, 6 a 9 vezes maior.

O maior risco do envolvimento em acidentes da motocicleta e da bicicleta devese aos seguintes fatos: por ter menor tamanho é maior a probabilidade de não ser vista pelos condutores dos outros tipos de veículos, por ter duas rodas é 
comum à perda de equilíbrio com consequente queda e/ou desvio de trajetória e por ser, muitas vezes, conduzida de maneira perigosa.

No caso dos ônibus/caminhões, o fato de serem maiores e, portanto, mais visíveis, de serem conduzidos por profissionais e de utilizarem velocidades comparativamente menores explicam o menor risco do envolvimento em acidentes.

A Tabela 2.2, estruturada por Koornstra ${ }^{4}$, indica valores do risco de morte associado aos principais tipos de veículos.

Tabela 2.2 - Taxa de mortalidade em função do modo de transporte nos países da União Europeia no biênio 2001 - 2002. Fonte: Koornstra.

\begin{tabular}{ccc}
\hline Modo de transporte & $\begin{array}{c}\text { Taxa de mortalidade por 100 } \\
\text { milhões de pass.km }\end{array}$ & $\begin{array}{c}\text { Probabilidade relativa } \\
\text { de óbito }\end{array}$ \\
\hline Ônibus e bonde & 0,07 & 0,1 \\
Carro & 0,7 & 1,0 \\
Bicicleta & 5,4 & 7,7 \\
A pé & 6,4 & 9,1 \\
Motocicleta/motoneta & 13,8 & 19,7 \\
\hline
\end{tabular}

$\mathrm{Na}$ Tabela 2.3 são apresentados os valores relativos ao risco de sofrer lesão em acidentes de trânsito, por modo de transporte, que correspondem a uma média dos valores de cinco países da Europa, tendo como referência o número de vítimas por passageiro-quilômetro.

Tabela 2.3 - Risco de sofrer lesão no trânsito x modo de transporte.

Fonte: Elvik et al.

\begin{tabular}{cc}
\hline Tipo de veículo & Risco relativo \\
\hline Ônibus & 0,5 \\
Carro & 1,0 \\
Bicicleta & 6,7 \\
A pé & 9,4 \\
Motocicleta/motoneta & 12,0 \\
\hline
\end{tabular}

\footnotetext{
${ }^{4}$ Koornstra, M.K. Transport Safety Performance in the EU. Brussels, European Transport Safety Council, 2003.
} 
O fato é que por não oferecer nenhuma proteção aos usuários (massa metálica deformante e efeito do cinto de resistência como existe nos carros), o risco dos acidentes envolvendo bicicletas e motocicletas resultarem em lesões graves nos seus ocupantes é muitíssimo maior do que no caso dos automóveis.

Os seguintes itens podem ser elencados como fatores de desestímulo ao uso da bicicleta:

- Insegurança;

- Raio de ação limitado;

- Clima e topografia;

- O comércio principal normalmente se encontra em vias de tráfego intenso ou áreas críticas para segurança no trânsito.

- O ciclista sente-se segregado ou discriminado por estar sendo levado a pedalar longe das vias principais, onde circulam carros e motos.

Uma pesquisa realizada pelo Instituto Brasileiro de Pesquisa Social (IBPS) em 2011 apontou que as principais justificativas para não optar pela bicicleta como meio de transporte são: a grande distância $(47,2 \%)$, o medo do trânsito $(8,1 \%)$, a falta de ciclovia $(7,5 \%)$ e a falta de integração com outros meios de transporte $(5,6 \%)$.

$\mathrm{Na}$ busca por alternativas não motorizadas de deslocamento nas cidades, principalmente as que se encontram em difícil situação em termos de mobilidade urbana, a bicicleta se mostra uma excelente alternativa, pois combina, para curtas distâncias, vantagens em relação a um veículo privado, além de vantagens sociais, econômicas e ambientais no que diz respeito ao transporte coletivo. Os benefícios gerados são diversos, pois é mais eficiente energeticamente, contribuindo para a diminuição do consumo de energia, da contaminação atmosférica, do aquecimento global e do ruído nas cidades. Pode ser utilizada por grande parte das pessoas e proporciona qualidade de vida e alto grau de autonomia à população como um todo. 
De maneira geral, as seguintes desvantagens para os usuários podem ser associadas ao uso da bicicleta:

- Necessidade de esforço físico, nem sempre desejável (às vezes, sim, pois pedalar é um ótimo exercício para a saúde);

- Produção de suor que umedece as roupas e pode provocar odor corpóreo desagradável;

- Impossibilidade (ou pelo menos grande desconforto) do uso em condições atmosféricas adversas: chuva, neve, frio, vento, etc;

- Impossibilidade de pedalar em rampas íngremes (nessa situação o usuário tem que caminhar empurrando a bicicleta);

- Muitas vezes pode trazer sensação de inferioridade social ao usuário;

- Maior risco de se envolver em acidentes de trânsito (nos países em desenvolvimento esse valor pode ser altíssimo);

- Maior risco de sofrer um acidente de trânsito grave, pois a bicicleta não oferece nenhuma proteção no caso de colisão.

Ademais, as principais desvantagens do uso da bicicleta para a sociedade são:

- Maior número de acidentes de trânsito;

- Maior número de acidentes de trânsito graves;

- Necessidade do investimento em ciclovias, ciclofaixas e bicicletários;

- Impacto negativo para o trânsito nas vias secundárias com as bicicletas circulando na via preferencial;

- Impacto negativo para o trânsito em vias estreitas, em razão da impossibilidade de ultrapassar a bicicleta que circula com velocidade baixa. 


\subsection{Impactos no sistema viário e de trânsito}

A estruturação de um sistema cicloviário inteligente e bem estruturado requer elementos econômicos, políticos e culturais já consolidados, cujos potenciais já se encontram inseridos no desenvolvimento e planejamento de várias cidades europeias. Nestas cidades, onde essa dinâmica já está presente há algum tempo, o espaço da rua é compartilhado entre os diferentes modais, de forma clara e objetiva. Entretanto, as vias de circulação são fisicamente segregadas e os entroncamentos muito bem sinalizados, a fim de melhor assegurar a integridade de seus usuários. O sistema cicloviário é parte componente de um sistema maior e possui a mesma importância em termos de veículo condutor. Ou seja, a lógica e o sucesso desse sistema estão tanto na educação e respeito de motoristas e ciclistas, como na ideia de que todo o sistema viário existente deve abrigar diferentes modais de transporte.

No que diz respeito à inserção do espaço de circulação para bicicletas nas vias urbanas, o Geipot (2001b) informa que a faixa compartilhada entre veículos e bicicletas deve medir entre 3,90m a 5,00m de largura. Já o manual do TRB Transportation Research Board (1994 apud Gondim, 2001) revela que à medida que a faixa cicloviária diminui os impactos causados pelos veículos sobre as bicicletas aumentam. Gondim (2001) reforça que apesar do manual do TRB (1994) não indicar critérios suficientes para o dimensionamento das ciclovias, suas constatações quanto à largura de faixas de tráfego na presença de ciclistas é satisfatória para a segurança e conforto em um tráfego compartilhado. Isso denota que é possível, tecnicamente, garantir a segurança e a integridade física dos usuários do sistema, sem comprometer a fluidez do tráfego de veículos.

Pezzuto (2002) complementa que devido às cidades brasileiras terem seus sistemas viários projetados para os automóveis, a bicicleta circula no espaço urbano em desvantagem pelo fato de possuir características operacionais, velocidades e porte com características distintas dos veículos motorizados.

Existem alguns fatores, inerentes à implantação de um sistema cicloviário que influenciam diretamente no sistema de circulação viário. O sistema cicloviário, 
na sua implantação, deve estar em consonância com o plano geral da cidade, estar adequado à mesma e obedecer às demandas que esse tipo de infraestrutura exige. Ou seja, toda e qualquer forma de estratégia para modificar o espaço viário, assim como a viabilidade de propostas cicloviárias, devem estar de acordo com a realidade do município e seus usuários.

Segundo o Manual de Projeto Geométrico de travessias urbanas do DNIT (Departamento Nacional de Infraestrutura de Transporte), publicado em 2010, existem variáveis que auxiliam e norteiam estudos para localização e posteriormente implantação de sistemas cicloviários. A seguir, algumas dessas variáveis:

- Nível de habilidade dos usuários - Informa que deve ser considerada a habilidade e preferência dos diferentes tipos de ciclistas que usufruirão dessa infraestrutura para se deslocar próximo à escolas, parques e áreas residenciais, onde a porcentagem de ciclistas infantis e inexperientes é superior a de ciclistas mais experientes;

- Impedimentos físicos - Em áreas com topografia muito acidentada, rios, ferrovias e vias expressas, por exemplo, deve-se avaliar a viabilidade de dispositivos viários ou de passagens exclusivas para atender ao tráfego potencial de ciclistas;

- Atendimento mais direto - Quando o tráfego de ciclistas for muito elevado entre origens e destinos, deve-se analisar a viabilidade de uma solução mais racional e adequada para os usuários do sistema;

- Acessibilidade - Considerar a provisão de acessos frequentes e adequados, especialmente nas áreas residenciais;

- Aparência - A paisagem urbana é de extrema relevância durante um percurso cicloviário, principalmente no que diz respeito a viagens recreativas e contemplativas; 
- Segurança pessoal - Consideração de possíveis atos criminosos contra ciclistas, especialmente em trechos de uso geral isolados, e a possibilidade de roubos ou vandalismo, em locais de estacionamento;

- Paradas - Ao longo de seu trajeto, grande parte dos ciclistas tende a seguir em velocidades constantes. Caso isso seja contrário, ou seja, os ciclistas são forçados a realizar paradas frequentes, isso pode fazer com que os mesmos abandonem a via ou desrespeite a sinalização e outros dispositivos de controle de tráfego;

- Conflitos - Existem diferentes tipos de vias em um sistema cicloviário, logo, são gerados diferentes tipos de conflitos. Dessa forma, esses conflitos, resultantes das faixas permitidas ou reservadas para ciclistas, derivam do confronto entre ciclistas e motoristas, no caso de ciclofaixas junto à via de circulação de veículos motorizados. Assim também como são comuns os conflitos entre ciclistas e pedestres;

- Manutenção - Esse item é essencial para que os ciclistas continuem a utilizar o sistema cicloviário, pois projetos que facilitam e simplificam os serviços de manutenção melhoram a segurança e a operação;

- Qualidade da superfície do pavimento - As vias de bicicletas devem apresentar pavimentação estritamente regular, livres de saliências, buracos. Dessa forma, o ciclista sente-se seguro ao trafegar pela mesma. Os diversos dispositivos de drenagem, como poços de inspeção, bocas de logo e grelhas devem respeitar a continuidade da superfície e, se possível, ficar fora da trajetória das bicicletas;

- Condições das interseções - As vias para ciclistas devem ser selecionadas, de modo a reduzir o número de interseções a atravessar, ou as interseções devem ser melhoradas, de modo a reduzir os conflitos nas travessias. As interseções em nível de grande volume (ou velocidades elevadas) e travessias de meio de quadra devem ser analisadas, tendo em mente as necessidades dos ciclistas, a fim de determinar as melhores condições para os projetos de travessia; 
- Custo/disponibilidades de recursos - Uma boa solução normalmente envolve uma análise de custos de alternativas. Sendo assim, estas alternativas podem ser limitadas pela falta de recursos. É importante, entretanto, que a falta de recursos não resulte em uma solução de má qualidade. A decisão de implantar um sistema de vias para ciclistas tem que levar em conta seu funcionamento a longo prazo, com adequada manutenção e que seja viável para a cidade. Quando os recursos são limitados, o foco deve ser dado em melhorias de baixo custo, como estacionamento de bicicletas, remoção de barreiras e obstruções ao tráfego de bicicletas.

O sistema cicloviário obviamente gera impactos no trânsito e na circulação urbana. Porém, cabe aos órgãos competentes e estudiosos do assunto, fazer com que esses impactos assumam um caráter benéfico no espaço urbano e ajudem na mobilidade das pessoas. Ciclovias e ciclofaixas são muito importantes para o desenvolvimento igualitário e democrático das cidades, mas se o projeto for mal pensado e realizado, o resultado final pode ser muito ruim não só para a bicicleta, mas também para outros modos motorizados e não motorizados.

O Manual de Planejamento Cicloviário realizado pelo Geipot (2001b), elenca de forma clara e precisa características e recomendações para cada tipo de via e possíveis consequências na estruturação de ciclovias nas mesmas. A Tabela 2.4 apresenta os locais e os graus de restrições à circulação das bicicletas no tráfego urbano das cidades. 
Tabela 2.4 - Vias e trechos do viário urbano com restrição às bicicletas.

Fonte: Geipot, 2001b.

\begin{tabular}{|c|c|c|c|c|}
\hline $\begin{array}{l}\text { VIAS E TRECHOS NAS } \\
\text { CIDADES }\end{array}$ & PRINCIPAIS CARACTERISTICAS & $\begin{array}{l}\text { GRAU DE } \\
\text { RESTRIÇÃ̄O }\end{array}$ & $\begin{array}{l}\text { CONSEQŪÊNCIAS } \\
\text { DO USO DA BICICLETA }\end{array}$ & $\begin{array}{l}\text { RECOMENDACÕES PARA O USO DA } \\
\text { BICICLETA }\end{array}$ \\
\hline Via Expressa & $\begin{array}{l}\text { Via com controle de acesso de } \\
\text { veículos, velocidade de tráfego superior } \\
\text { a } 100 \mathrm{~km} / \mathrm{h} \text {, com poucos acessos, e que } \\
\text { se destina à ligação entre regiōes de } \\
\text { grandes metrópoles }\end{array}$ & Total & $\begin{array}{l}\text { - Acidentes graves em razão da } \\
\text { velocidade da corrente de tráfego; } \\
\text { - Dificuldade em cruzar, entrar e sair } \\
\text { da via }\end{array}$ & $\begin{array}{l}\text { - Construção de ciclovia lateral; (não } \\
\text { recomendada sequer a adoçẫo de } \\
\text { ciclofaixas). }\end{array}$ \\
\hline $\begin{array}{l}\text { Canaleta exclusiva ao } \\
\text { transporte coletivo }\end{array}$ & Via exclusiva à circulação de ônibus & Total & $\begin{array}{l}\text { - Inobservância da mão dupla dos } \\
\text { coletivos; } \\
\text { - Impossibilidade de ultrapassar, em } \\
\text { segurança, os coletivos parados nos } \\
\text { pontos de parada }\end{array}$ & $\begin{array}{l}\text { - Liberação do uso nos finais de semana, } \\
\text { quando decresce muito o número de } \\
\text { coletivos em circulação nessas áreas. }\end{array}$ \\
\hline Via Arterial & $\begin{array}{l}\text { Via geralmente com grande extensão, } \\
\text { permite acesso a áreas diferenciadas } \\
\text { do territónio das cidades. Têm muitos } \\
\text { cruzzamentos, velocidade da corrente } \\
\text { de tráfego variando entre } 60 \text { e } 80 \mathrm{~km} / \mathrm{h} \text {, } \\
\text { grande número de veículos } \\
\text { motorizados nos horários de pico e a } \\
\text { presença de muitos veículos com } \\
\text { grande tonelagem, como caminhões e } \\
\text { ônibus }\end{array}$ & Parcial & $\begin{array}{l}\text { - Conflitos e acidentes com veículos } \\
\text { motorizados, devido muito mais ao } \\
\text { volume desses do que as suas } \\
\text { velocidades; } \\
\text { - Confiltos com ônibus e pedestres } \\
\text { nos pontos de parada; } \\
\text { - Conflitos com os automóveis } \\
\text { particulares no bordo direito da pista } \\
\text { em razão do acesso desses às } \\
\text { garagens e aos estacionamentos; } \\
\text { - Conflitos nos cruzamentos, em } \\
\text { especial em vias de mão dupla, e } \\
\text { onde há conversões à esquerda }\end{array}$ & $\begin{array}{l}\text { - Criação de ciclofaixa, quando houver } \\
\text { disponibilidade de espaço, ou ainda, } \\
\text { dotaçấo de faixa da direita de } \\
\text { sobrelargura de } 1,20 \mathrm{~m}, \text { no máximo, para } \\
\text { permitir a circulaçấo de bicicletas no } \\
\text { espaço excedente a uma faixa; } \\
\text { - Criação de áreas de refúgio para a } \\
\text { bicicleta e pedestres, na área de } \\
\text { aproximaçâo nos cruzamentos antes da } \\
\text { conversão à esquerda. }\end{array}$ \\
\hline Túneis & $\begin{array}{l}\text { Via subterrânea ou sob área de } \\
\text { montanha. Permite a ligação de } \\
\text { correntes de tráfego a bairros e regiões } \\
\text { do territónio urbano das grandes } \\
\text { cidades com certa rapidez }\end{array}$ & Total & $\begin{array}{l}\text { - Acidentes graves em razão da } \\
\text { velocidade da corrente de tráfego; } \\
\text { - Ciclistas sujeitos a mal-estar devido } \\
\text { a forte presença de gases tóxicos; } \\
\text { - Vulnerabilidade dos ciclistas, por } \\
\text { não terem áreas abrigadas } \\
\text { destinadas à parada diante de } \\
\text { situações emergenciais }\end{array}$ & $\begin{array}{l}\text { - Previsão de passagem elevada, nos } \\
\text { novos túneis, com minimo de } 1,20 \mathrm{~m} \text { de } \\
\text { largura, sendo } 1,00 \mathrm{~m} \text { livre, para a } \\
\text { passagem de bicicletas; } \\
\text { - Previsão da destinação de um lado para } \\
\text { cada tipo de usuáno, caso exista } \\
\text { passagem de pedestre. }\end{array}$ \\
\hline Calçadões de pedestres & $\begin{array}{l}\text { Áreas nos centros urbanos destinadas } \\
\text { à circulaçấo de pessoas e mercadorias, } \\
\text { livres do tráfego motorizado }\end{array}$ & Parcial & $\begin{array}{l}\text { - Conflitos com pedestres em função } \\
\text { de sua grande presença e dos } \\
\text { inúmeros destinos desses }\end{array}$ & $\begin{array}{l}\text { - Instalação de bicicletários nas suas } \\
\text { extremidades; } \\
\text { - Colocação de paraciclos junto aos } \\
\text { principais pontos de atraçãa, fora do } \\
\text { calçadão. }\end{array}$ \\
\hline $\begin{array}{l}\text { Pontes, viadutos e } \\
\text { elevados }\end{array}$ & $\begin{array}{l}\text { Obras de arte de Engenharia, } \\
\text { construidas para transpor acidentes } \\
\text { naturais (rios, vales, etc.) ou correntes } \\
\text { de tráfego muito movimentadas }\end{array}$ & Parcial & $\begin{array}{l}\text { - Grande fricção com o tráfego geral, } \\
\text { sem muitas possibilidades de evitar } \\
\text { conflitos }\end{array}$ & $\begin{array}{l}\text { - Destinação de área especial para o } \\
\text { trânsito de bicicletas na mesa da obra- } \\
\text { de-arte; } \\
\text { - Colocação de "mãos-francesas", na } \\
\text { lateral externa, garantindo ofluxo } \\
\text { segregado de bicicletas e pedestres. }\end{array}$ \\
\hline $\begin{array}{l}\text { Via de comércio local nos } \\
\text { grandes centros }\end{array}$ & $\begin{array}{l}\text { Baixo volume de tráfego, caixa de via } \\
\text { estreita, grande movimentação de } \\
\text { mercadorias e pedestres }\end{array}$ & Parcial & $\begin{array}{l}\text { - Conflitos com veículos de carga e } \\
\text { pedestres em função de sua grande } \\
\text { presença }\end{array}$ & $\begin{array}{l}\text { - Seleção das melhores rotas e } \\
\text { sinalização das mesmas; } \\
\text { - Colocação de paraciclos junto aos } \\
\text { principais pontos de atração de viagens. }\end{array}$ \\
\hline $\begin{array}{l}\text { Avenida } \\
\text { à beira-mar }\end{array}$ & $\begin{array}{l}\text { Em geral tem boa caixa de via, grandes } \\
\text { áreas destinadas ao estacionamento } \\
\text { de veículos e cruzamento generalizado } \\
\text { de pedestres }\end{array}$ & Parcial & $\begin{array}{l}\text { - Conflitos com pedestres; } \\
\text { - Conflitos com veículos estacionados }\end{array}$ & $\begin{array}{l}\text { - Colocação de paraciclos junto à área da } \\
\text { praia; } \\
\text { - Construção de ciclovia na orla; } \\
\text { - Construção de ciclofaixa no lado oposto } \\
\text { aos edíficios. }\end{array}$ \\
\hline $\begin{array}{l}\text { Terminais de carga, } \\
\text { portos e retroportos }\end{array}$ & $\begin{array}{l}\text { Grandes espaços viários, próximos ou } \\
\text { não de áreas portuárias e de grandes } \\
\text { estruturas rodoviárias, com muitos } \\
\text { veículos de carga }\end{array}$ & Parcial & $\begin{array}{l}\text { - Conflitos com veículos de carga; } \\
\text { - Conflitos com veículos realizando } \\
\text { manobras para carga e descarga }\end{array}$ & $\begin{array}{l}\text { - Criação de bicicletários em lugar seguro, } \\
\text { longe dos locais de manobras de } \\
\text { caminhỗes; } \\
\text { - Criação de ciclofaixa em área abrigada } \\
\text { dos caminhões. }\end{array}$ \\
\hline
\end{tabular}

\subsection{Conceito de redes e integrações cicloviárias}

Segundo o IEMA (2010), em princípio, todas as vias podem ser utilizadas para a plena circulação de bicicletas. Entretanto, quanto maior for o volume de tráfego na via e a velocidade de veículos motorizados, menos o ciclista se sentirá seguro e estimulado, devido ao risco de acidentes. A questão da segurança é intrínseca aos tipos de deslocamentos realizados nas cidades. Isso leva a uma máxima: a bicicleta não é um veículo seguro como meio de 
transporte. Essa prerrogativa, comum nos ideais da população, é o início de diversos equívocos inerentes ao transporte cicloviário.

Em primeiro lugar é errôneo condicionar o uso da bicicleta à construção de ciclovias, pois se torna o primeiro obstáculo na implementação de um sistema de transporte cicloviário. Em segundo lugar, a questão da segurança não envolve somente a construção de ciclovias e ciclofaixas (muitas delas mal dimensionadas e localizadas). A segurança como atributo de qualidade do sistema, pode ser em grande parte minimizado, mesmo sem as ciclovias e ciclofaixas, por meio de ações educativas, como as campanhas de conscientização e projetos de moderação do tráfego motorizado (IEMA, 2010).

A escolha do tipo de intervenção a ser realizada deve considerar a racionalidade dos percursos, minimizando distâncias e estabelecendo uma rede lógica de percursos. Ou seja, para se constituir uma rede cicloviária são necessárias várias ações, conjuntas ao planejamento e crescimento da cidade, que ofereçam boas alternativas de rotas e caminhos, de forma segura e confortável. Dessa forma, além de atrair usuários, assegura o transporte cicloviário como um sistema de transporte eficiente para a cidade.

Uma rede boa rede cicloviária deve ligar importantes atividades urbanas como: ir ao centro; terminais urbanos (metrô, trem ônibus); Universidades, escolas, centros esportivos etc. Além de assumir um papel de extrema importância na mobilidade urbana, as redes cicloviárias são compostas por diversas tipologias viárias, concomitantes ou não, e possuem um acerta hierarquização entre elas.

O Manual de Planejamento Cicloviário do Geipot (2001b) é muito claro:

No Sistema Cicloviário Compartilhado, a rede pode se constituir de vias adaptadas ou não à circulação da bicicleta. Nesse caso, os ciclistas circulam em ruas e outras vias com baixo tráfego motorizado e nível de segurança elevado, caracterizadas no seu conjunto como rotas cicláveis, a exemplo do projeto Ciclorede, no Vale do Rio Pinheiros, na cidade de São Paulo. Esse tipo de rede representa o primeiro nível de intervenção em favor dos ciclistas em espaços urbanos já configurados.

No segundo caso, Sistema Cicloviário Preferencial, a rede inclui espaços destinados ao uso exclusivo ou com prioridade à 
bicicleta, como ciclovias e ciclofaixas. Observa-se que, nesse caso, as vias compartilhadas, para fazerem parte da rede preferencial, deverão sofrer intervenções do tipo traffic calming, visando a garantia da segurança da circulação dos ciclistas e a prioridade da bicicleta. Na prática, esses sistemas dificilmente cobrirão todas as "linhas de desejo" dos ciclistas, que necessitarão utilizar, de forma compartilhada, as demais vias, conceituadas acima como espaços naturais, recaindo-se no sistema definido adiante.

No Sistema Cicloviário de Uso Misto, a rede apresenta trechos e rotas compartilhadas entre bicicletas e o tráfego motorizado, além das infraestruturas específicas à circulação da bicicleta. Esse tipo de sistema é o de maior facilidade para implantação nos espaços urbanos brasileiros, em virtude da característica e configuração da maioria das cidades do país. Em muitas cidades brasileiras o sistema viário é estreito, tortuoso e confinado entre prédios, cujas testadas possuem calçadas também estreitas, em especial nas suas áreas centrais. (Manual de Planejamento Cicloviário, 2001b)

Um sistema cicloviário pode ser classificado por meio de ciclovias e ciclofaixas. As primeiras são totalmente separadas do tráfego motorizado e podem ser construídas paralela a um rua, avenida ou em locais específicos. Já as ciclofaixas também são construídas junto às demais vias, mas são menos isoladas do tráfego motorizado e, normalmente, possuem mão única.

Há também tipologias que mesclam o tráfego de bicicletas com os passeios e áreas para pedestres, mas isso depende muito da largura disponível e do fluxo. Esse tipo de intervenção deve ser muito bem planejado, pois o risco de acidentes é eminente. É prudente considerar as diferentes combinações de pavimentos e suas cores, a fim de proporcionar mais segurança aos pedestres e ciclistas.

Outra forma de estruturar um sistema cicloviário como parte de uma rede é o conceito de rotas cicláveis, que nada mais são do que caminhos que o ciclista pode utilizar com segurança, em vias compartilhadas com o tráfego motorizado de baixo volume e baixa velocidade.

O conceito de rede não se restringe apenas ao transporte cicloviário. Uma cidade bem planejada e estruturada deve compor à rede cicloviária todos os 
demais modos de transportes, promovendo um espaço democrático e mais acessível a todos. Segundo Rau (2012) as redes cicloviárias levam em consideração todas as possibilidades de conciliar o uso da bicicleta com outros modos de transporte, auxiliando assim as demais formas de deslocamento não motorizadas. Além disso, a rede cicloviária potencializa os deslocamentos, facilitando 0 acesso aos serviços disponíveis, locais de interesse e equipamentos urbanos, bem como reforça a possibilidade de gerar uma intermodalidade com o sistema de transporte coletivo por ônibus, metrô e trem.

A questão da baixa integração com outros meios de transportes nas cidades brasileiras está vinculada a diversos outros fatores, dentre os quais se destacam os aspectos institucionais e culturais, que rebaixam o pedestre e 0 ciclista, como se fossem cidadãos de segunda classe. Com isso, as viagens realizadas por estes modos, a pé e bicicleta, acabam não sendo viabilizadas, mesmo estas sendo uma das formas mais simples de ligação entre os modos diversos modos de transportes. Assim, os maiores problemas encontrados para a implantação de sistemas intermodais, promovendo assim, integração entre os modos, encontram-se em uma análise fragmentada, pouco lógica acerca dos sistemas de mobilidade, que resulta em soluções pontuais e ineficazes.

Para que as redes intermodais se estabeleçam de fato, todos os modos de transporte devem ser considerados e estruturados entre si, compondo um sistema de rede completo e que ofereça opções aos cidadãos locais. Sendo assim, a integração deve considerar primordialmente o deslocamento a pé, visto este possuir a maior prioridade com relação aos demais meios de transporte, - e o uso de bicicletas como modos de integração entre os demais modos de maior capacidade.

Uma rede cicloviária deve oferecer conexões entre as origens e destinos para todos os ciclistas, sempre de forma segura e atrativa, especialmente nos trajetos mais importantes da cidade. Caso isso não ocorra, muitos ciclistas optarão por trajetos alternativos, normalmente não planejados e inadequados para o tráfego de bicicletas. Ou seja, devem ser evitados implantações cicloviárias com infraestruturas isoladas e que não seguem uma coerência e 
uma continuidade em relação à intervenções urbanas. Miranda (2007) ainda reforça:

Tem sido comum no Brasil a construção de ciclovias isoladas, como se uma determinada extensão de espaço exclusivo à circulação de ciclistas pudesse atender às necessidades de viagens dos ciclistas. [...] As cidades que apresentam melhores resultados quanto à reintrodução da bicicleta como veículo de transporte mostram a importância da construção de redes cicloviárias.

Portanto, uma infraestrutura cicloviária deve formar uma unidade coerente e conectar todos os pontos e destinos dos ciclistas, garantindo conforto, segurança, atratividade, continuidade e consistência de qualidade.

Na Figura 2.8 é mostrada a rede cicloviária da cidade de Bogotá, Colômbia, considerada uma rede bastante adequada. 


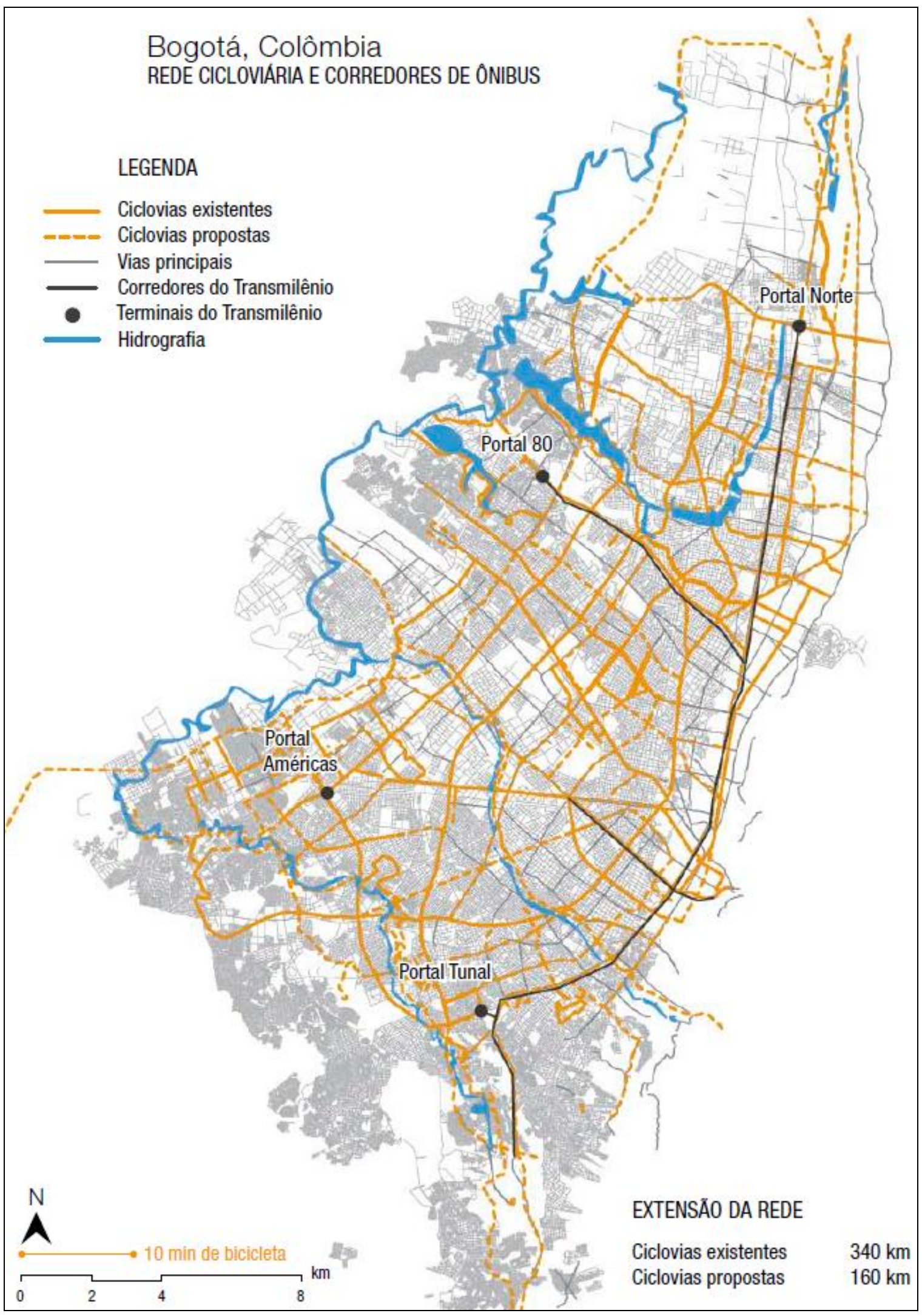

Figura 2.8 - Mapa de Rede Cicloviária e Corredores de Ônibus de Bogotá. Fonte: www.bogota.gov.co, 2010. 
Segundo Pezzuto (2002), em áreas urbanas, a distância entre dois pontos utilizando a bicicleta é, na maioria das vezes, maior que a distância por automóvel. Isto se deve ao fato de que o sistema viário é projetado para veículos motorizados e não existem muitas rotas alternativas, diretas e principalmente seguras para os ciclistas. Diante disso, para evitar vias com muito tráfego, congestionadas em horário de pico ou ainda, cruzamentos perigosos e descontinuidades como vazios urbanos e aclives muito acentuados, os ciclistas são obrigados, muitas vezes, a seguir caminhos tortuosos e mais longos.

Segundo SHAFIZADEH e NEIMEIER (1997) a percepção da distância está associada, também, à qualidade do meio por onde o ciclista trafega, sendo que os ciclistas ao viajarem em ciclovias, tendem a realizar viagens mais longas.

Fica evidente que todas as distâncias de viagem estão relacionadas com a estrutura urbana, de como o espaço urbano foi organizado e também com o padrão de uso e ocupação do solo. Ademais, PUCHER et al.,(1999 apud Pezzuto, 2002) reforçam que cidades espalhadas, com baixa densidade de ocupação e com centros de emprego distantes dos bairros residenciais, têm menor índice de utilização das bicicletas devido às maiores distâncias de viagem.

\subsection{Aspectos técnicos}

Segundo o Plano de Mobilidade por Bicicletas nas Cidades, desenvolvido pelo Ministério das Cidades, a infraestrutura cicloviária é meio favorável e indispensável à utilização da bicicleta em uma determinada área do território. Um projeto cicloviário tem que atender às especificações mínimas, para que então, ofereça suporte ao usuário de forma eficiente e segura. Para que todas essas especificações sejam atendidas, uma estrutura hierarquizada foi estabelecida a fim de nortear toda a infraestrutura necessária para 0 desenvolvimento desse tipo de meio de transporte. 
Inserido dentro de um sistema de transporte o veículo utilizado para realizar devidos deslocamentos no espaço urbano é a bicicleta. Esse tipo de veículo possui dimensões espaciais que devem seguir de referência para a elaboração de um projeto cicloviário. A Figura 2.9 mostra as dimensões mínimas necessárias, segundo Geipot (2001b).

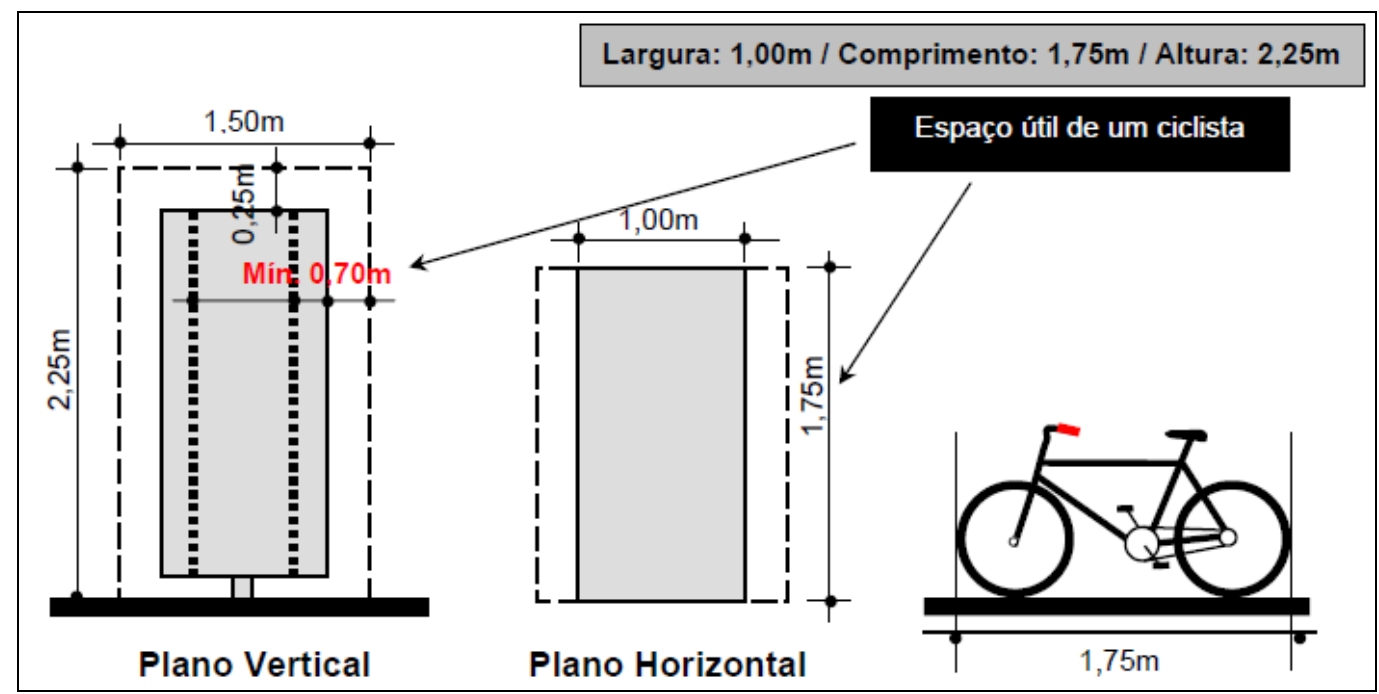

Figura 2.9 - Espaço útil do ciclista. Fonte: Geipot, 2001b.

No que se refere a dimensões da bicicleta no espaço urbano de circulação, obviamente que são inferiores às dimensões dos carros e ônibus por exemplo. Entretanto, pouco se percebe que esse ganho em termos dimensionais, pode auxiliar em muito na redução de congestionamentos e numa melhor fluidez do tráfego urbano. Como efeito de comparação, para ilustrar essa situação descrita, a Figura 2.10 revela o espaço requerido por cada modo de transporte. 


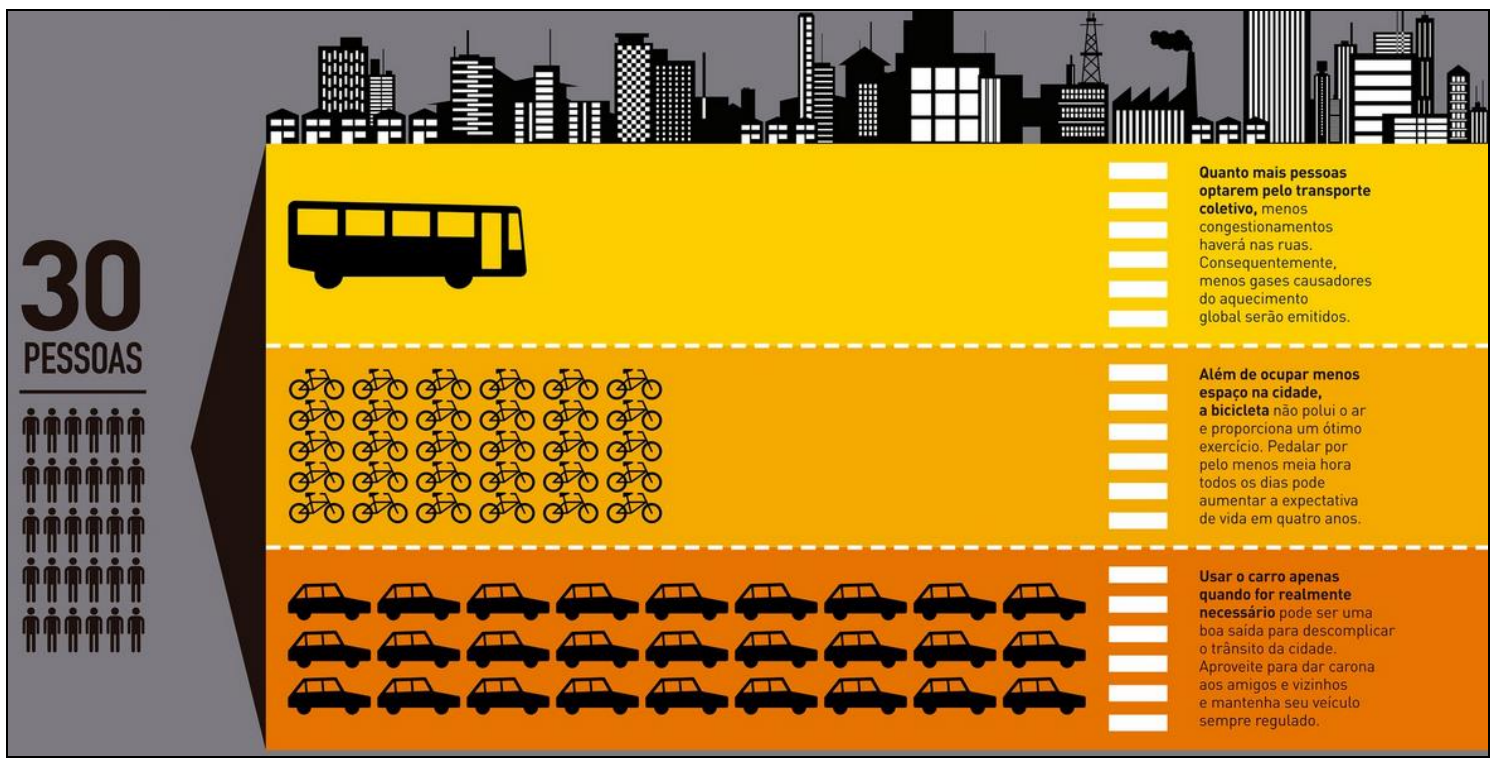

Figura 2.10 - Espaço requerido por modo de transporte.

Fonte: Associação dos ciclistas urbanos de Belo Horizonte, 2010.

Os espaços cicloviários são divididos e estruturados conforme a especificidade de cada situação local. Esses espaços são:

- Ciclovias;

- Ciclofaixas;

- Vias cicláveis e

- Ciclorrotas.

\section{Ciclovias}

Segundo Geipot (2001b), a ciclovia é:

É o espaço destinado à circulação exclusiva de bicicletas, separado da pista de rolamento dos outros modos por terrapleno, com mínimo de $0,20 \mathrm{~m}$ de desnível, sendo, habitualmente, mais elevada do que a pista de veículos motorizados. No sistema viário, pode localizar-se ao longo do canteiro central ou nas calçadas laterais. A ciclovia também pode assumir traçado totalmente independente da malha viária urbana ou rodoviária (como as ciclovias situadas sobre antigos leitos ferroviários). Nesses casos, deverá ter controle de acesso, ou seja, a acessibilidade dos ciclistas a ela deverá ser projetada de forma segura e eficiente em todos seus cruzamentos com outras estruturas viárias. 
A Figura 2.11 ilustra o padrão de ciclovias bidirecionais.

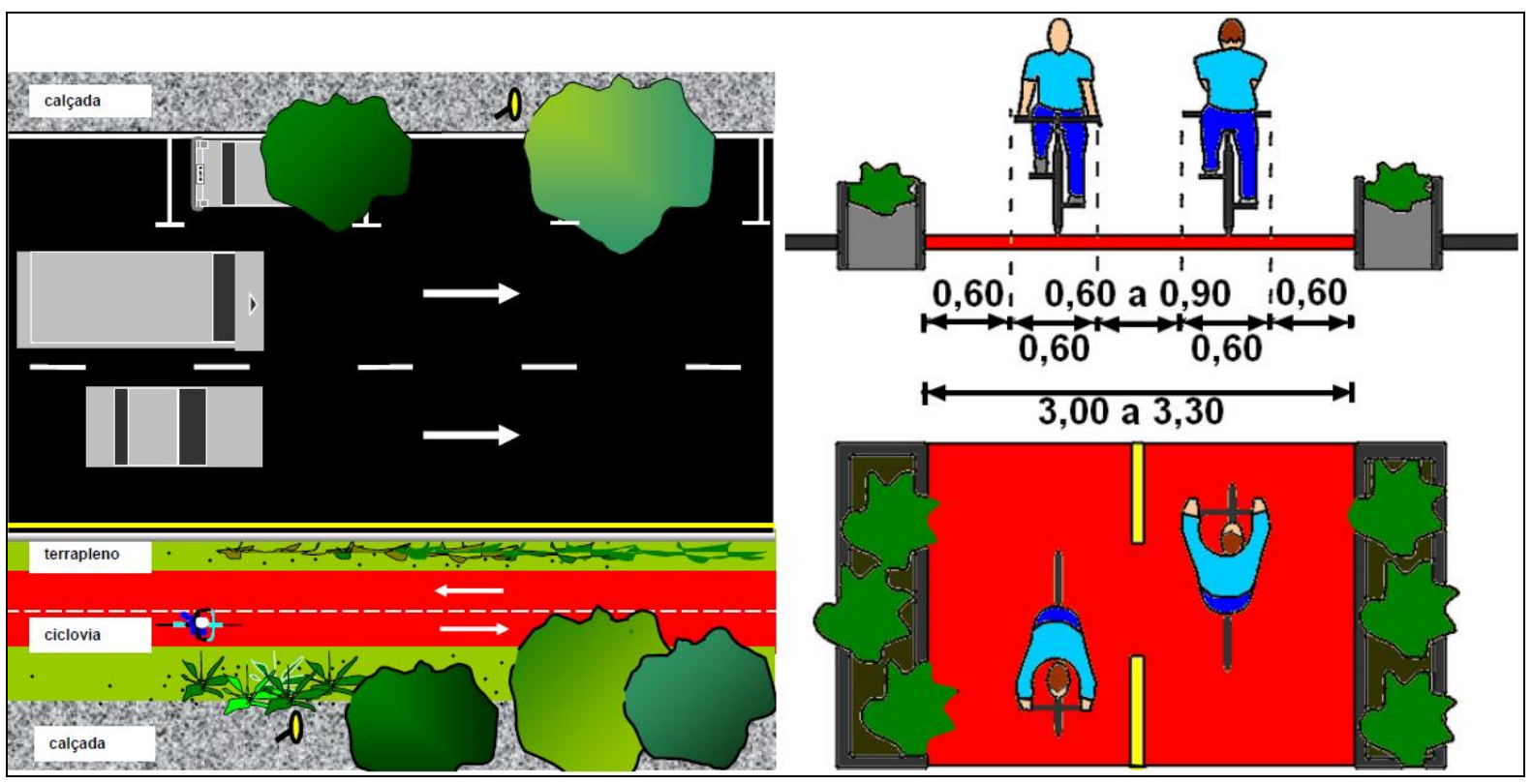

Figura 2.11 - Exemplo de ciclovia. Fonte: Geipot, 2001b.

Além do mais, as ciclovias atendem por convenção a um volume máximo de usuários e podem ser uni ou bidirecionais, dependendo da situação e do desenho urbano local. A Tabela 2.5 mostra as dimensões básicas para cada tipo de estrutura:

Tabela 2.5 - Características de ciclovias. Fonte: Brasil, 2001.

\begin{tabular}{|c|c|c|}
\hline Tipo & $\begin{array}{l}\text { Volume de tráfego } \\
\text { (bicicletas/hora) }\end{array}$ & Largura efetiva \\
\hline \multirow{4}{*}{$\begin{array}{c}\text { Ciclovia } \\
\text { unidirecional }\end{array}$} & até 1000 bic/hora & $2,00 \mathrm{~m}$ a $2,50 \mathrm{~m}$ \\
\hline & de 1000 a 2500 bic/hora & $2,50 \mathrm{~m}$ a $3,00 \mathrm{~m}$ \\
\hline & de 2500 a 5000 bic/hora & $3,00 \mathrm{~m}$ a $4,00 \mathrm{~m}$ \\
\hline & acima de 5000 bic/hora & $4,00 \mathrm{~m}$ a $6,00 \mathrm{~m}$ \\
\hline \multirow{4}{*}{ Ciclovia bidirecional } & até 1000 bic/hora & $2,50 \mathrm{~m}$ a $3,00 \mathrm{~m}$ \\
\hline & de 1000 a 2500 bic/hora & $3,00 \mathrm{~m}$ a $4,00 \mathrm{~m}$ \\
\hline & de 2500 a 5000 bic/hora & $4,00 \mathrm{~m}$ a $6,00 \mathrm{~m}$ \\
\hline & acima de 5000 bic/hora & maior que $6,00 \mathrm{~m}$ \\
\hline
\end{tabular}

Um fator relevante é que quando a ciclovia possui bordas desniveladas em mais de $0,10 \mathrm{~m}$, há necessidade do acréscimo de 0,50m na mesma. As Figuras 
2.12 e 2.13 ilustram respectivamente os perfis de ciclovias unidirecionais e bidirecionais.

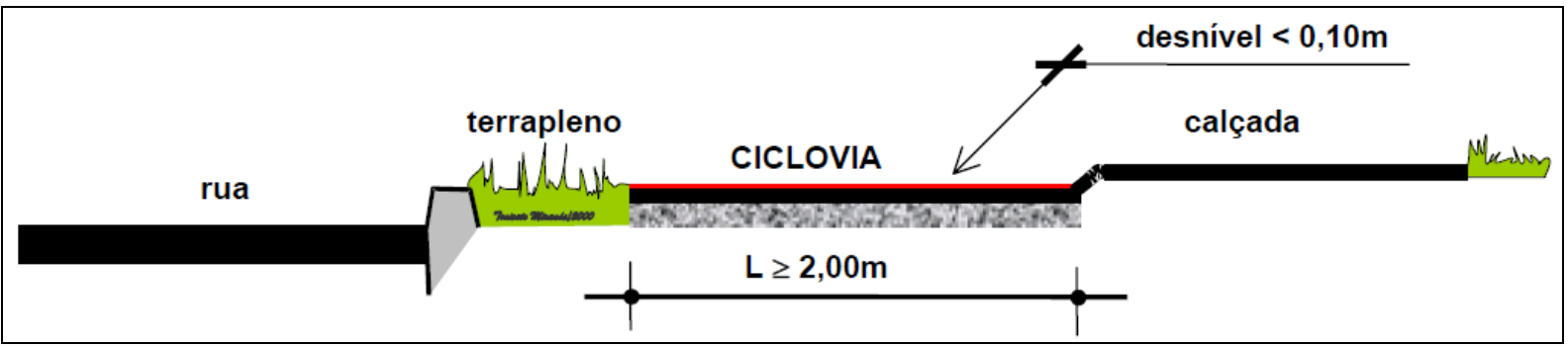

Fiqura 2.12 - Exemplo de ciclovia unidirecional sem desnível. Fonte: Geipot, 2001b.

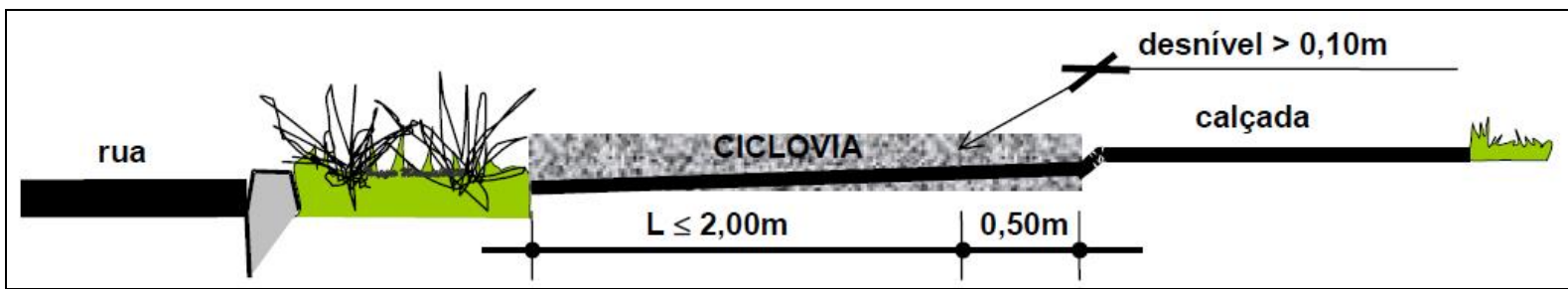

Fiqura 2.13 - Exemplo de ciclovia unidirecional com desnível. Fonte: Geipot, 2001b.

Quando existir no local arborização lateral em relação à ciclovia, deve ser acrescentado, além da superlargura de 0,50m, mais 0,25m. Esse acréscimo na infraestrutura cicloviária é importante, pois evita que haja interferência do tronco das árvores ou de qualquer obstáculo fixo sobre os ciclistas (Geipot, 2001b), conforme mostra a Figura 2.14.

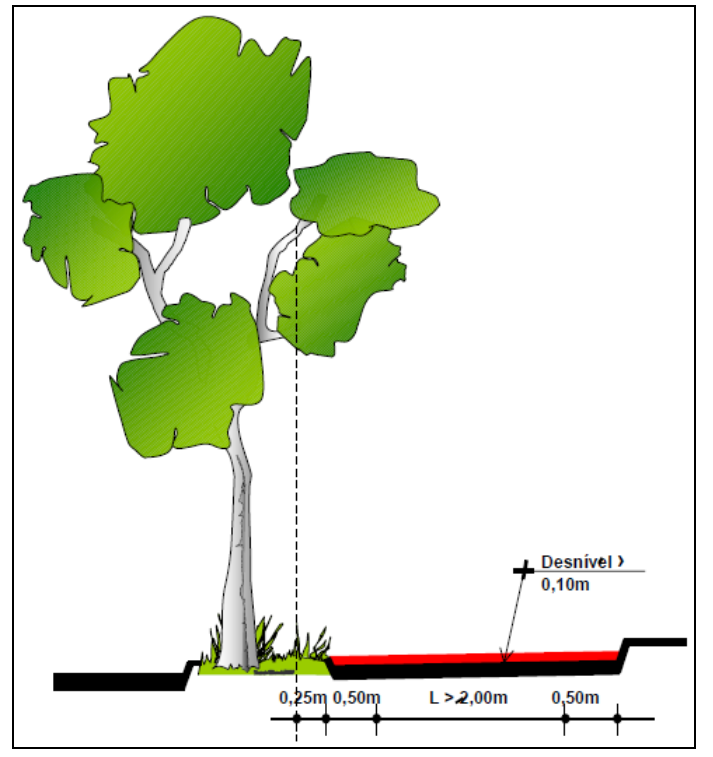

Figura 2.14 - Exemplo de ciclovia unidirecional com vegetação lateral. Fonte: Geipot, 2001b. 
Segundo Geipot (2001b), a ciclovia bidirecional tem como largura ideal 3,00m, mas é aceitável dimensioná-la até o mínimo de 2,50m. No caso de desnível lateral superior a 0,10m (calçada, terrapleno, etc), é imprescindível adotar uma sobrelargura de 0,50m, a exemplo daquela apresentada nas pistas unidirecionais. A Figura 2.15 ilustra um exemplo de ciclovia bidirecional.

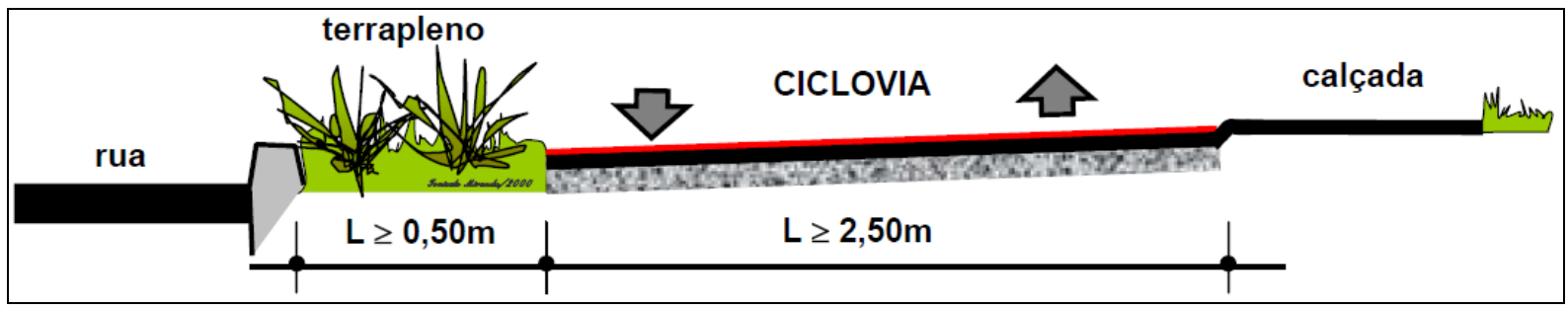

Figura 2.15 - Exemplo de ciclovia bidirecional. Fonte: Geipot, 2001b.

\section{Ciclofaixas}

A ciclofaixa obedece a características distintas das ciclovias. Esta deve obrigatoriamente ser sempre unidirecional, objetivando garantir segurança elevada em toda sua extensão. Segundo o Plano de Mobilidade por Bicicletas, a ciclofaixa, na aproximação dos cruzamentos, quando houver espaço, deve ser canalizada, deixando assim, a condição de ciclofaixa para ser uma ciclovia, pelo menos em pequena extensão. O Manual de Planejamento Cicloviário do Geipot (2001b) define a ciclofaixa como:

\footnotetext{
Espaço viário destinado à circulação de bicicletas, contíguo à pista de rolamento de veículos automotores, sendo dela separada por pintura, dispositivos delimitadores (chamados de "tachinhas", "tartarugas" ou "calotas", dependendo de sua dimensão) ou por ambos.
}

Usualmente, define-se como sendo de 1,20m a largura mínima interna de uma ciclofaixa, devendo a ela ser acrescida a faixa de separação da corrente do tráfego motorizado. É importante criar espaço de separação entre a ciclofaixa e a via de circulação de tráfego motorizado. Essa separação pode ser feita por meio de pintura de faixas paralelas, preenchido com pinturas em diagonal, formando "zebrados", acrescentando-se ainda "tachinhas" refletivas (Geipot, 2001b). Este espaço deve ter um mínimo de 0,40m que, somando-se à faixa 
separadora da via ciclável da linha do meio-fio $(0,20 \mathrm{~m})$, eleva a largura total da ciclofaixa para 1,80m, de acordo com a Figura 2.16.

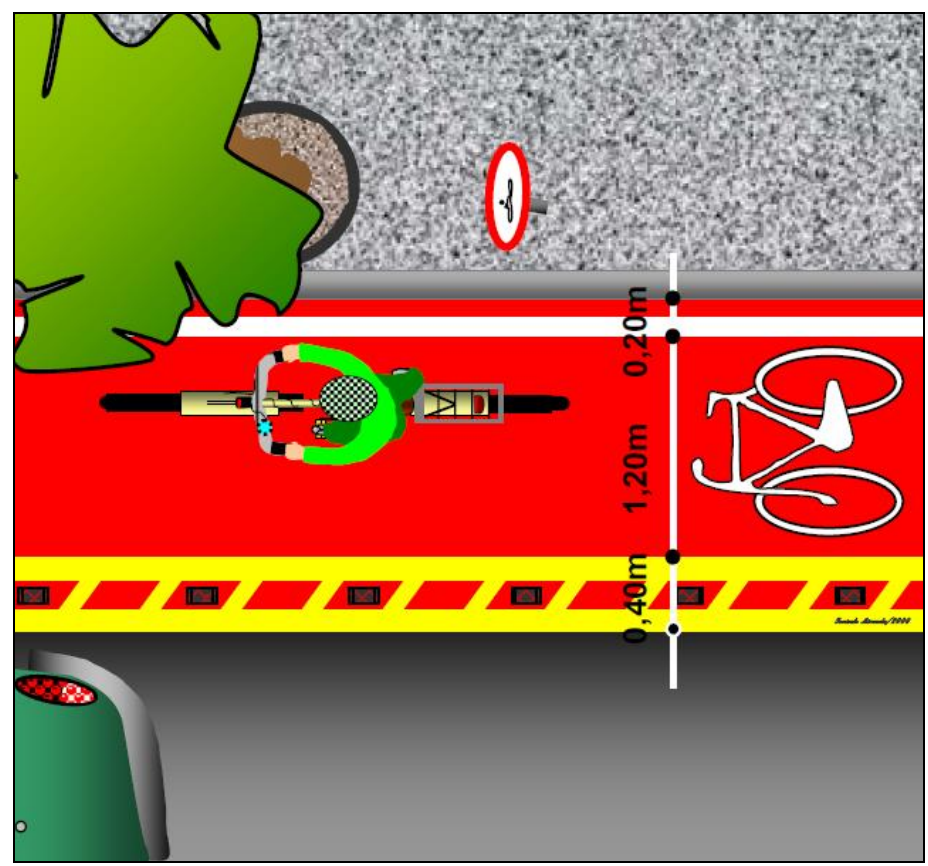

Figura 2.16 - Exemplo de ciclofaixa. Fonte: Geipot, 2001b.

A Tabela 2.6 mostra as dimensões básicas para a ciclofaixa:

Tabela 2.6 - Características de ciclofaixas. Fonte: Brasil, 2001.

\begin{tabular}{ccc}
\hline Tipo & $\begin{array}{c}\text { Volume de tráfego } \\
\text { (bicicletas/hora) }\end{array}$ & Largura efetiva \\
\hline $\begin{array}{c}\text { Ciclofaixa }- \\
\text { Unidirecional }\end{array}$ & Todos & $1,80 \mathrm{~m}$ (externa) \\
\hline
\end{tabular}

A estruturação de uma ciclofaixa requer cuidados especiais, pois ela ocupa de certa forma uma parcela do leito carroçável, ou seja, parte destinada à circulação de veículos motorizados. O Manual do Geipot divide a estruturação de uma ciclofaixa em quatro situações:

1. Ciclofaixa junto ao bordo direito da via, ao lado do meio fio, em vias onde é proibido o estacionamento de automóveis nos seus dois lados, Figura 2.17 a seguir; 


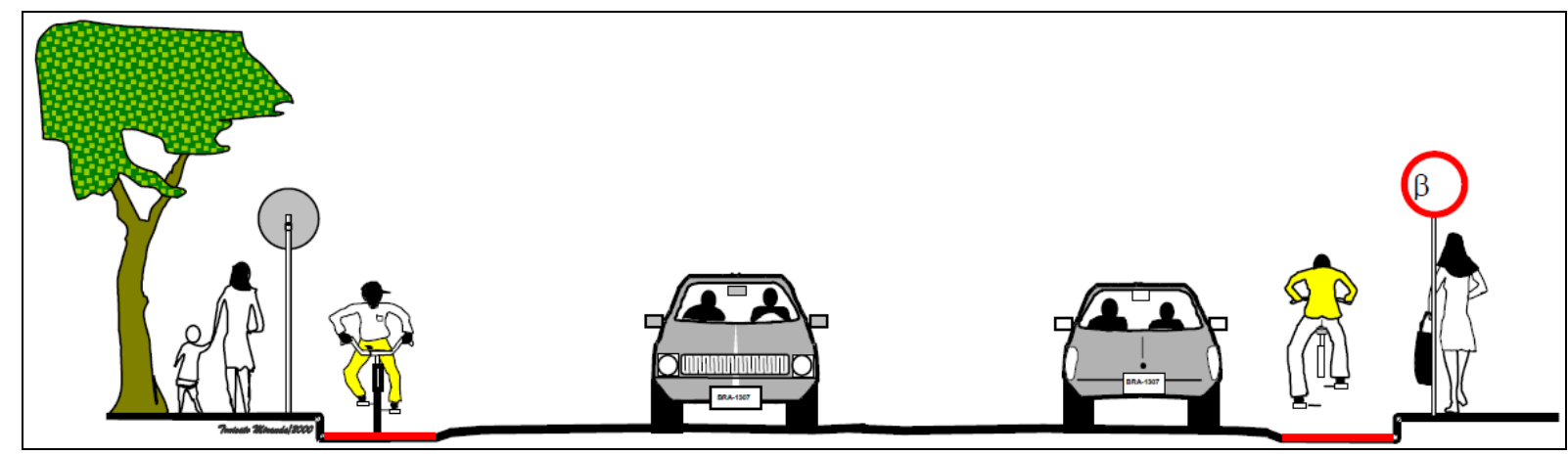

Figura 2.17 - Posicionamento de ciclofaixa: Situação 1. Fonte: Geipot, 2001b.

2. Ciclofaixa situa-se entre a área de estacionamento e o bordo do meiofio, ao lado da calçada de pedestres, conforme Figura 2.18;

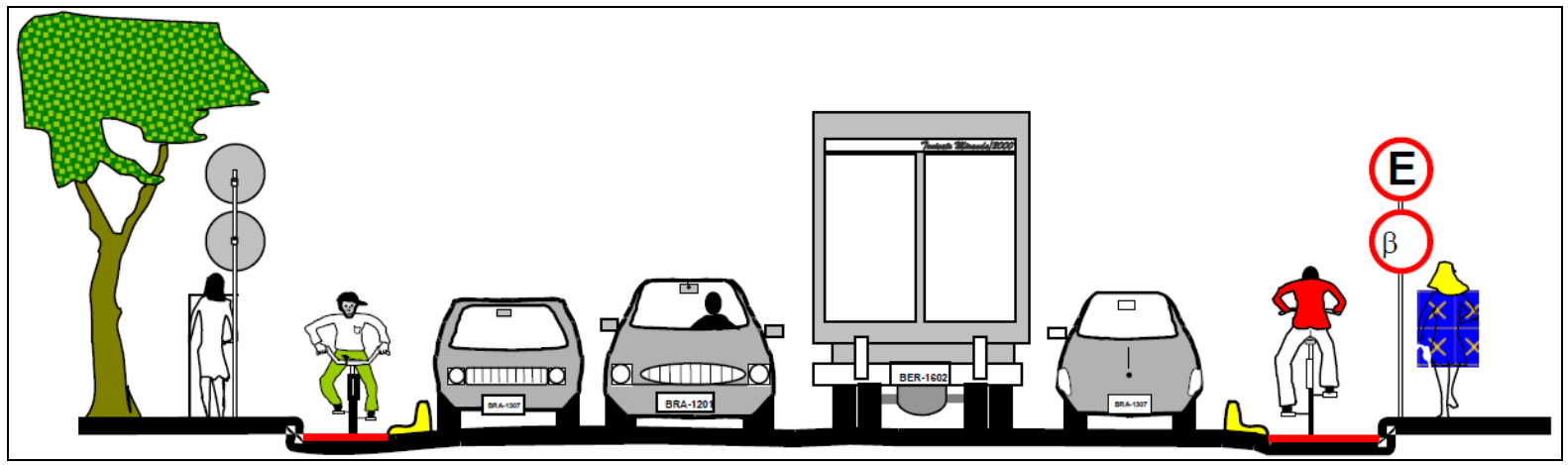

Figura 2.18 - Posicionamento de ciclofaixa: Situação 2. Fonte: Geipot, 2001b.

3. Ciclofaixa implantada logo após a linha de estacionamento. Nesse caso, admite-se o estacionamento de automóveis ao longo do meio-fio, sendo vedado o de veículos maiores, que representam obstrução à visão do ciclista, agravando as situações de risco.

4. Em vias onde a faixa para veículos motorizados do bordo direito apresenta uma sobrelargura, ou seja, tem mais de 3,50m e menos de $5 \mathrm{~m}$. Essa faixa permite que a bicicleta se acomode na porção excedente da largura padrão de uma faixa de tráfego motorizado. Embora não haja caracterização explícita de uma ciclofaixa nesse caso, tal proposta permite aumentar a segurança do ciclista no tráfego compartilhado.

A Figura 2.19 ilustra as situações 3 e 4 de implantação de ciclofaixas. 


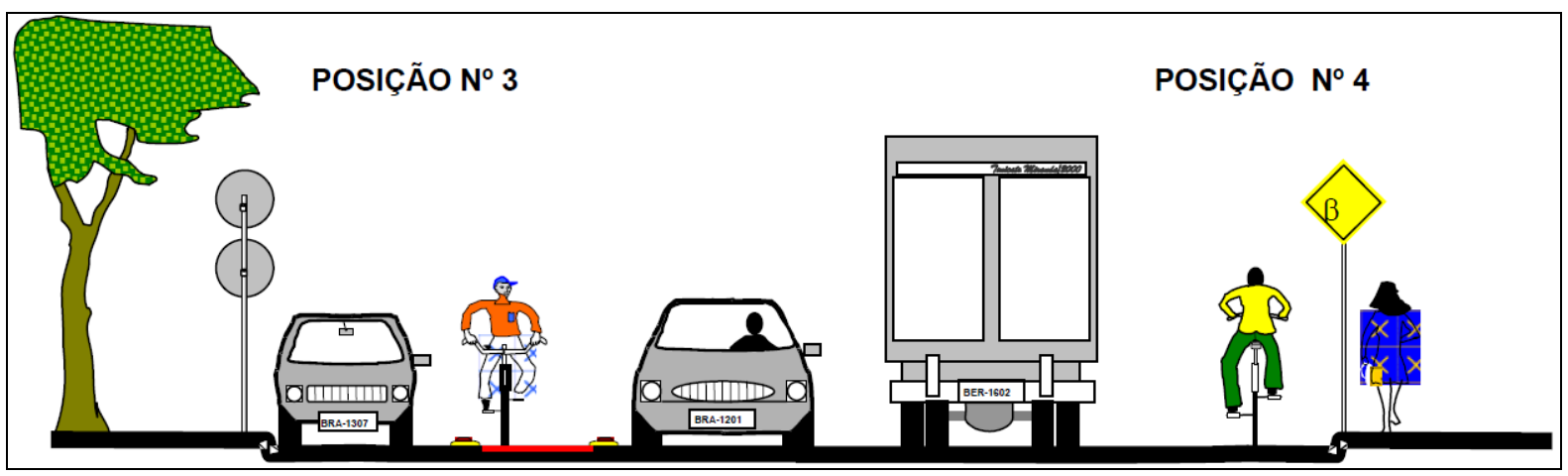

Figura 2.19 - Posicionamento de ciclofaixa: Situações 3 e 4. Fonte: Geipot, 2001b.

\section{Rampas das ciclovias}

A questão da declividade limite em um projeto cicloviário é item determinante na escolha do melhor trajeto. Em muitos casos, o ciclista prefere circular em trechos onde a rampa tem uma inclinação elevada, mas com pequena extensão, ao invés de rampas suaves, porém longas.

O Manual do Geipot (2001b) aconselha a adotar, nesse caso, rampas escalonadas, ou seja, em patamares nivelados, definindo um greide de projeto mais agradável. A Figura 2.20 mostra as relações entre as rampas normais e máximas admissíveis em função do desnível a ser vencido.

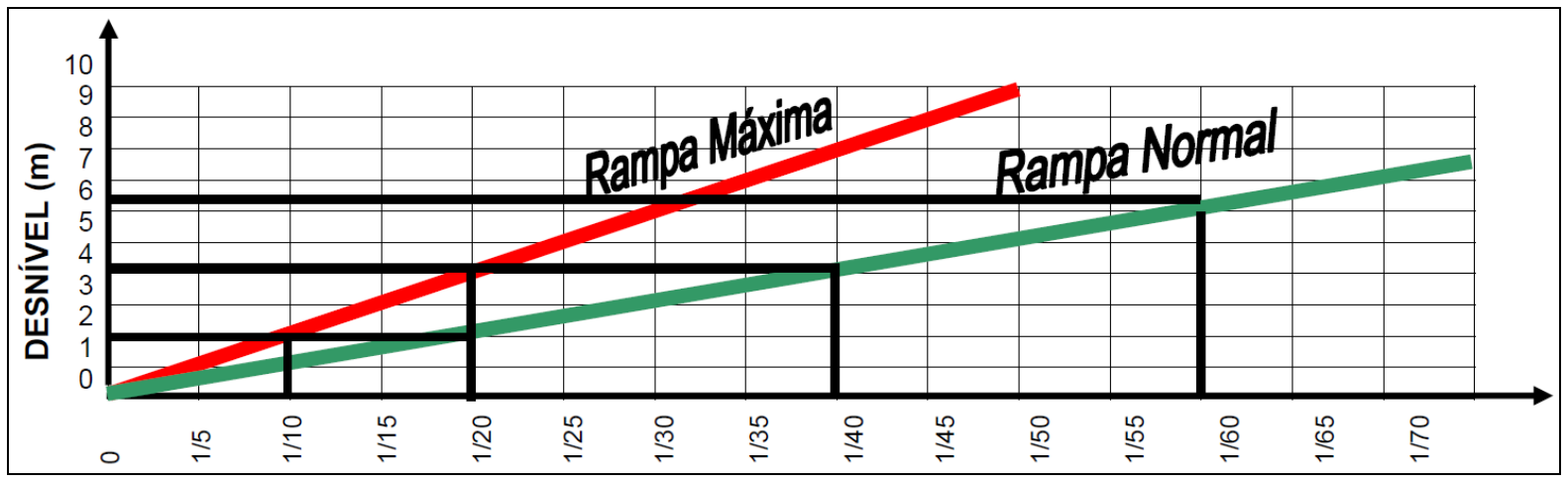

Figura 2.20 - Rampas admissíveis em ciclovias e ciclofaixas. Fonte: Geipot, 2001b.

Os valores da Tabela 2.7 auxiliam no entendimento dos valores normais e máximos admissíveis na concepção do projeto geométrico de uma ciclovia ou ciclofaixa. 
Tabela 2.7 - Relação entre inclinação da via e rampas máximas e normais. Fonte: Adaptado de Riccardi, 2010.

\begin{tabular}{cccc}
\hline \multicolumn{2}{c}{ Inclinação } & \multicolumn{2}{c}{ Distância (m) } \\
\hline Fração & Porcentagem & Rampa Máxima & Rampa Normal \\
$1 / 50$ & 2,00 & 500 & 250 \\
$1 / 45$ & 2,22 & 405 & 202,5 \\
$1 / 40$ & 2,50 & 320 & 160 \\
$1 / 35$ & 2,86 & 245 & 122,5 \\
$1 / 30$ & 3,33 & 180 & 90 \\
$1 / 25$ & 4,00 & 125 & 62,5 \\
$1 / 20$ & 5,00 & 80 & 40 \\
$1 / 15$ & 6,67 & 45 & 22,5 \\
$1 / 10$ & 10,00 & 20 & 10 \\
$1 / 5$ & 20,00 & 5 & 2,5 \\
\hline
\end{tabular}

\section{Vias cicláveis}

As vias cicláveis, segundo o Manual do Geipot (2001b), são caminhos formados por segmentos viários ou espaços e trilhas naturais no campo ou na cidade, que podem ser utilizados pelos ciclistas na ligação entre uma origem e um destino. Esses caminhos, dependendo da configuração e da complexidade do espaço urbano, podem ser compartilhados entre pedestres, assumindo uma via que comporta dois tipos de locomoção: a pé e por bicicleta.

O Artigo 59 do CTB regulamenta a possibilidade ao tráfego de bicicletas nos passeios. Essa possibilidade é bastante importante, pois existem várias situações no espaço urbano em que a circulação da bicicleta sobre as calçadas, além de não causar graves riscos à integridade física dos pedestres, possibilita ao ciclista maior segurança à sua circulação. A Figura 2.21 mostra um trecho de via na cidade de Curitiba, onde ocorre o uso compartilhado de pedestres e ciclistas. 


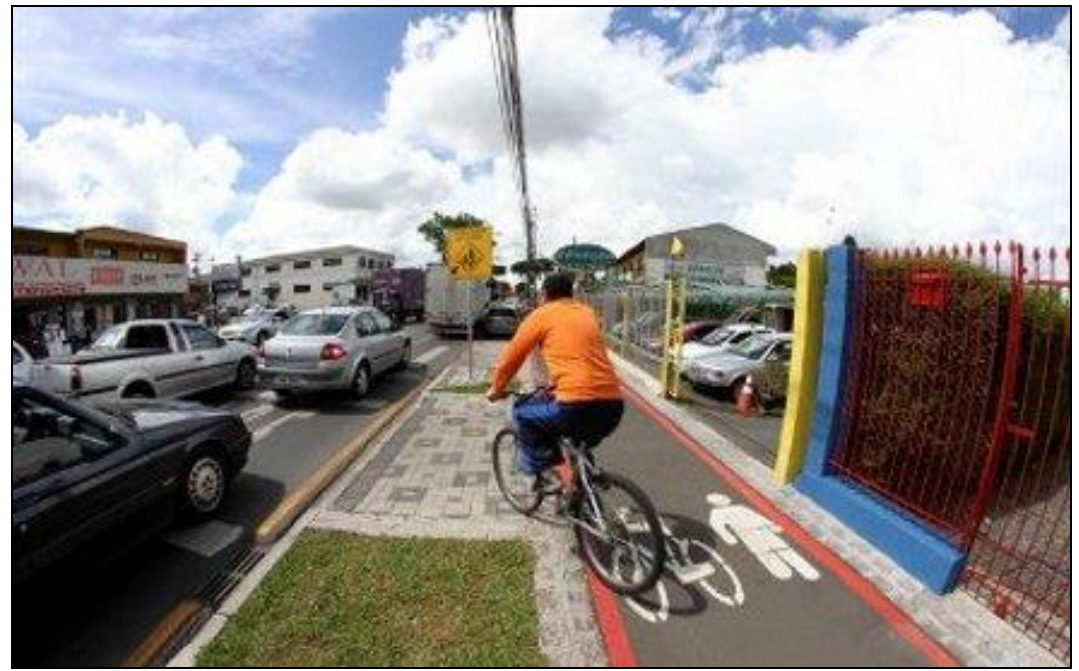

Figura 2.21 - Via ciclável de uso compartilhado em Curitiba/PR. Fonte: www.vadebici.worldpress.com

\section{Ciclorrota}

Ciclorrota é um termo relativamente recente. Uma ciclorrota consiste em um caminho que recebe sinalização vertical e horizontal (placas e pintura de solo,) alertando os motoristas sobre a presença e a prioridade a ser dada ao tráfego de bicicletas. Além do mais, como atributos, o trajeto representa o melhor caminho para o ciclista chegar ao seu destino final e a velocidade veicular máxima é de $30 \mathrm{Km} / \mathrm{h}$. As ciclorrotas costumam ser implementadas em regiões críticas, onde as avenidas principais são estreitas, com tráfego rápido e corredores de ônibus. Ademais, estrutura-se esse tipo de tipologia quando não houver ruas paralelas às grandes avenidas que possam se tornar caminhos intuitivos (Fonte: CET, 2013). A Figura 2.22 mostra um exemplo de ciclorrota no bairro Moema em São Paulo. 


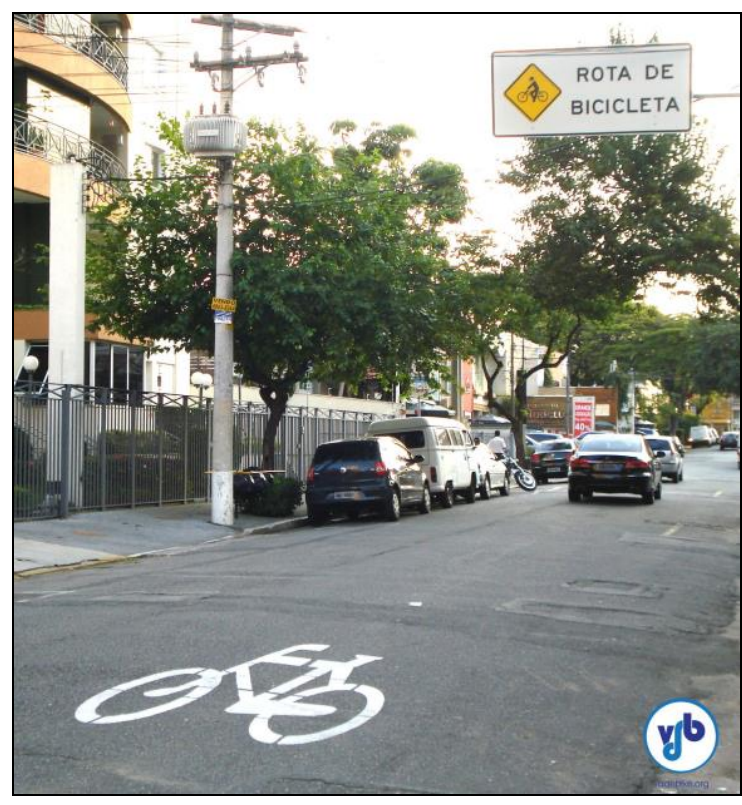

Figura 2.22 - Ciclorrota em Moema/SP. Fonte: www.vadebike.org, 2010.

\section{Paraciclos e bicicletários}

Os paraciclos são caracterizados como estacionamentos de curta ou média duração (até 2 horas, em qualquer período do dia), com até 25 vagas (correspondente à área de duas vagas de veículos automotores), de uso público e sem qualquer controle de acesso.

Esse tipo de infraestrutura é muito importante em centros urbanos, principalmente em cidades onde a cultura do uso da bicicleta é notória, pois a facilidade de acesso constitui uma das principais características dos paraciclos. Em virtude dessa condição, esse tipo de estacionamento deve estar posicionado o mais próximo possível do local de destino dos ciclistas, e também do sistema viário ou do sistema cicloviário.

Segundo o Manual do Geipot (2001b), um aspecto importante é a atenção que os administradores e projetistas devem dar ao planejamento da distribuição de paraciclos no espaço urbano ou nas zonas de periferia urbana ou rural. A implantação de vários paraciclos de pequena capacidade junto aos destinos dos ciclistas é mais vantajoso do que, por exemplo, de apenas um, de grande capacidade, com característica de bicicletário, a uma distância média maior dos 
pontos de destino na mesma área. As Figuras 2.23 e 2.24 a seguir ilustram exemplos de paraciclos encontrados na cidade de São Paulo.

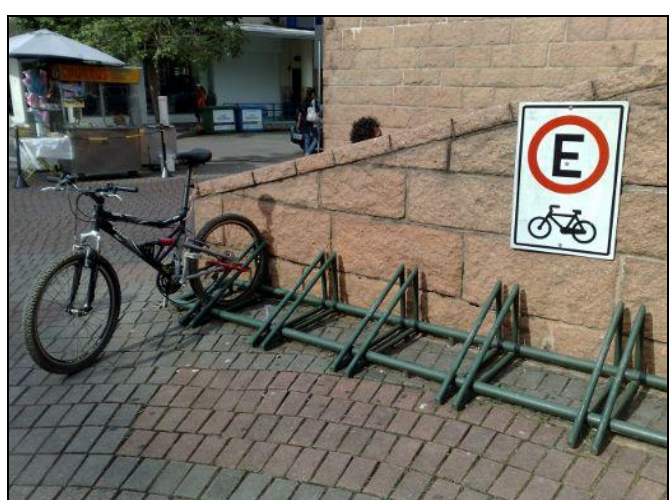

Figura 2.23 - Exemplo 1 de paraciclo. Fonte: www.vadebike.org, 2010.

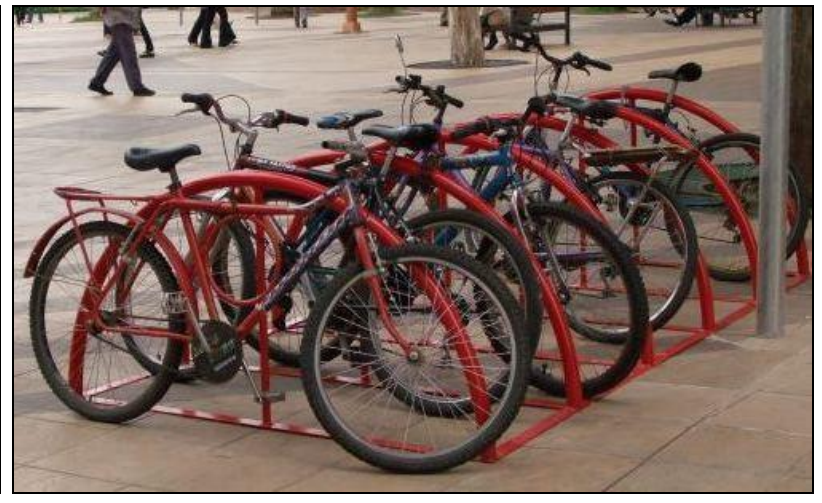

Figura 2.24 - Exemplo 2 de paraciclo. Fonte: www.vadebike.org, 2010

Por sua vez, o termo bicicletário refere-se aos locais de estacionamentos de longa duração, com grande número de vagas e controle de acesso, podendo ser públicos ou privados.

Os bicicletários e paraciclos possuem distinções entre si. Segundo o Manual do Geipot (2001b), uma das diferenças significativas dos bicicletários em relação aos paraciclos, além do tempo maior da guarda das bicicletas, são os picos de movimentação dos ciclistas, normalmente em horários de entradas e saídas de jornadas de trabalho ou, ainda, no início e final de atividade para a qual o ciclista foi atraído inicialmente. É de extrema importância que antes da concepção final do bicicletário, no momento da elaboração de projeto, são necessários levar em consideração aspectos ergonômicos e físicos, pois estes interferem diretamente no dimensionamento dos acessos e da circulação interna do próprio bicicletário.

No que diz respeito à segurança e acessibilidade, a entrada aos bicicletários deve ser protegida em relação aos fluxos de veículos automotores, ou seja, não é recomendado o acesso direto da via pública à área dos bicicletários. Por meio deste procedimento o risco no momento da entrada no estacionamento é muito menor, sendo o mesmo no sentido inverso, quando grande número de 
ciclistas busca retornar aos locais de origem. (Manual Geipot, 2001b). As Figuras 2.25 e 2.26 mostram os exemplos de bicicletários.

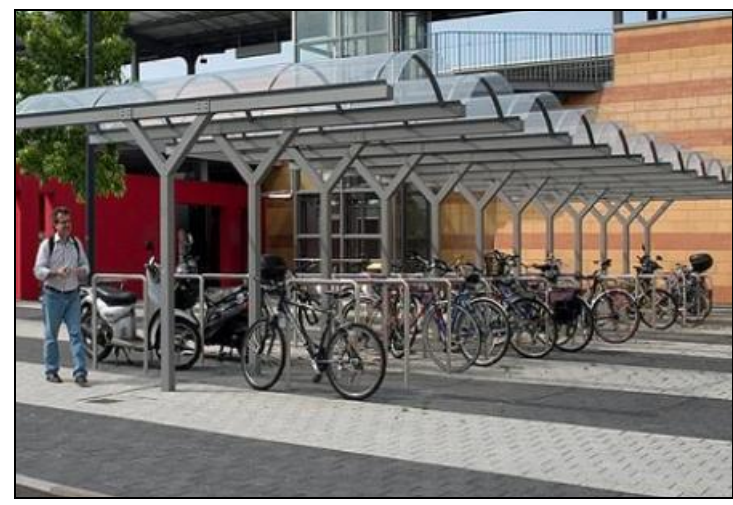

Figura 2.25 - Exemplo de bicicletário. Fonte: www.vadebike.org, 2010.

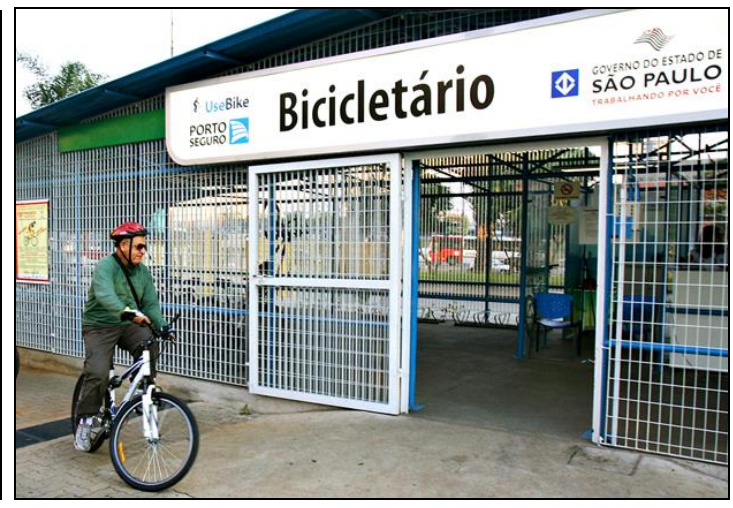

Figura 2.26 - Exemplo de bicicletário na cidade de São Paulo.

Fonte: www.vadebike.org, 2010.

\section{Pavimentação}

Em relação à pavimentação o Manual do Geipot (2001b) faz a seguinte recomendação:

Os requisitos básicos para uma ciclovia ou ciclofaixa, no tocante ao pavimento, são os seguintes: a superfície de rolamento deverá ser regular, impermeável, antiderrapante e, se possível, de aspecto agradável. As ciclovias não são submetidas a grandes esforços, não necessitando de estrutura maior do que a utilizada para vias de pedestres. No entanto, ocorre de seus traçados cortarem áreas de acesso a garagens, estacionamentos fechados e outros locais destinados à guarda de veículos motorizados. Nesses casos, sugere-se a adoção de reforço de base, com armação em malha em ferro sob camada de concreto magro.

\section{Segurança e fluidez}

No caso da estruturação de uma ciclovia ou ciclofaixa, quesitos como fluidez e segurança, acabam se confrontando, sendo impedâncias para a concepção de uma infraestrutura adequada. Cabe lembrar que um dos principais fatores para o não estímulo ao uso das bicicletas é a segurança. 
Segundo (GARDER,1994, FWHA, 1992b, MORITZ 1997 apud Pezzuto, 2002), a preocupação com a segurança é um dos fatores mais citados como impedimento ao uso da bicicleta, tanto com relação à possibilidade de acidentes, quanto com relação à vulnerabilidade para assaltos e agressões. Os acidentes estão intrínsecos ao movimento e à circulação em meio urbano, pois diante de tantas origens e destinos que se realizam nas cidades, a exposição aos acidentes é algo real e concreto. Logicamente, as colisões com veículos motorizados não são os únicos acidentes que podem ocorrer com ciclistas. 0 usuário da bicicleta pode se acidentar ao colidir com objetos estacionários, como postes, placas, árvores ou ainda por má condução da bicicleta, podendo ocorrer derrapagens, quedas e mesmo por colisões com pedestres ou outros ciclistas. 


\section{3- CARACTERIZAÇÃO E AVALIAÇÃo DO SISTEMA CICLOVIÁRIO DE ARARAQUARA}

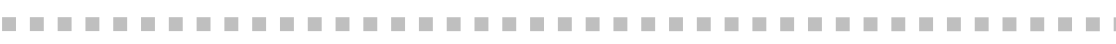

\subsection{Informações gerais do município}

Localizado na região central do Estado de São Paulo, o Município de Araraquara conta com 222.036 habitantes. A cidade encontra-se a uma distância rodoviária de 277 km de São Paulo, capital do Estado. Na Tabela 3.1 são relacionados alguns dados gerais do município.

Tabela 3.1 - Dados gerais do município de Araraquara.

Fonte: IBGE (2013), DENATRAN (2013).

\begin{tabular}{lc}
\hline População (habitantes) & $\mathbf{2 2 2 . 0 3 6}$ \\
\hline Índice de desenvolvimento humano municipal - IDHM & $\mathbf{0 , 8 1 5}$ \\
\hline Renda per capita em reais correntes (R\$/hab) & $\mathbf{8 9 1 , 7 9 4}$ \\
\hline Frota veicular (veículos) & $\mathbf{1 5 3 . 4 7 2}$ \\
\hline Índice de motorização (veículos/100habitantes) & $\mathbf{6 9 , 1 2}$ \\
Índice de Gini & $\mathbf{0 , 5 0 3 9}$ \\
\hline *Índice de Gini da renda domiciliar per capita (quanto mais próximo de \\
zero maior a distribuição da renda; quanto mais próximo de 1 menor a \\
distribuição da renda).
\end{tabular}

A malha viária de Araraquara apresenta um traçado ortogonal em forma de grelha com ruas estreitas e entrecortadas a cada aproximadamente cem metros. As principais vias interligam o centro da cidade às diversas regiões e bairros afastados, caracterizando uma rede viária hierarquizada e definida $\begin{array}{lllll}\text { fisicamente } \text { mostrado na } & \text { Figura } & \text { 3.1. }\end{array}$ 


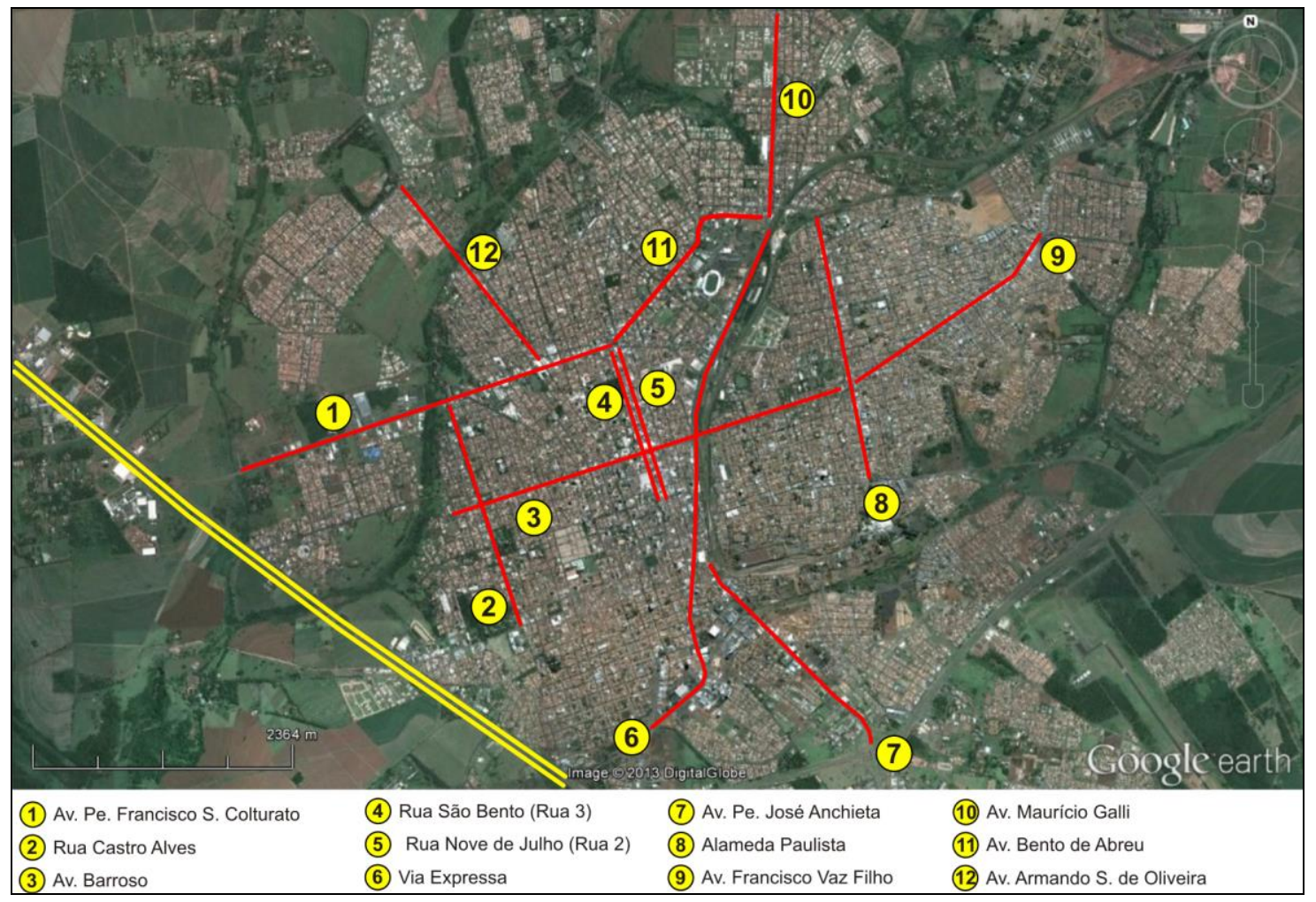

Figura 3.1 - Mapa com as principais vias da cidade de Araraquara.

Os principais corredores comerciais, as ruas Nove de Julho e São Bento extrapolam os limites da área central no sentido Sul - Norte, cruzando três importantes eixos viários: Av. Barroso (que tem início na Vila Xavier, Zona Leste, como continuação da Av. Francisco Vaz Filho, com o nome de Av. Pe. Antônio Cezarino, até cruzar o centro e terminar no Jardim Morumbi, Zona Oeste); Av. Pe. Francisco S. Colturato (importante via que oferece um dos acessos à Rodovia Washington Luiz e termina na confluência entre as Ruas Nove de Julho, São Bento e Bento de Abreu); Av. Bento de Abreu (eixo importante e histórico da cidade que interliga a zona Norte com o centro, sendo continuada pelas Avenidas Luiz Alberto e Maurício Galli). Outra importante via de circulação é a Via Expressa que acomoda grande fluxo de tráfego e permite a travessia da cidade de forma rápida.

O índice de motorização da cidade é de 69 veículos para cada 100 habitantes índice $76 \%$ maior que a média nacional e superior ao da França e da Alemanha (próximos de 60) e no mesmo nível do Japão (próximo de 70). Nos últimos 10 
anos, a frota da cidade praticamente dobrou, saindo dos 75 mil veículos e atingindo aproximadamente 141 mil carros.

\subsection{Sistema Cicloviário}

O sistema cicloviário de Araraquara tem 3.330 metros de extensão (6.660 metros considerando em separado cada sentido), sendo constituído dos seguintes três segmentos:

- Segmento 1 - Ciclovia bidirecional situada nas ruas Armando Salles de Oliveira e José Palamone Lepre; tem extensão total de 1.300 metros.

- Segmento 2 - Ciclovia bidirecional situada no canteiro central da Avenida Antônio Honório Real; tem extensão de 1.000 metros.

- Segmento 3 - Ciclovia bidirecional situada ao lado de um dos acostamentos da Av. Alberto Toloi; tem extensão de 1.030 metros.

Na Figura 3.2 é mostrada a localização desses três segmentos cicloviários.

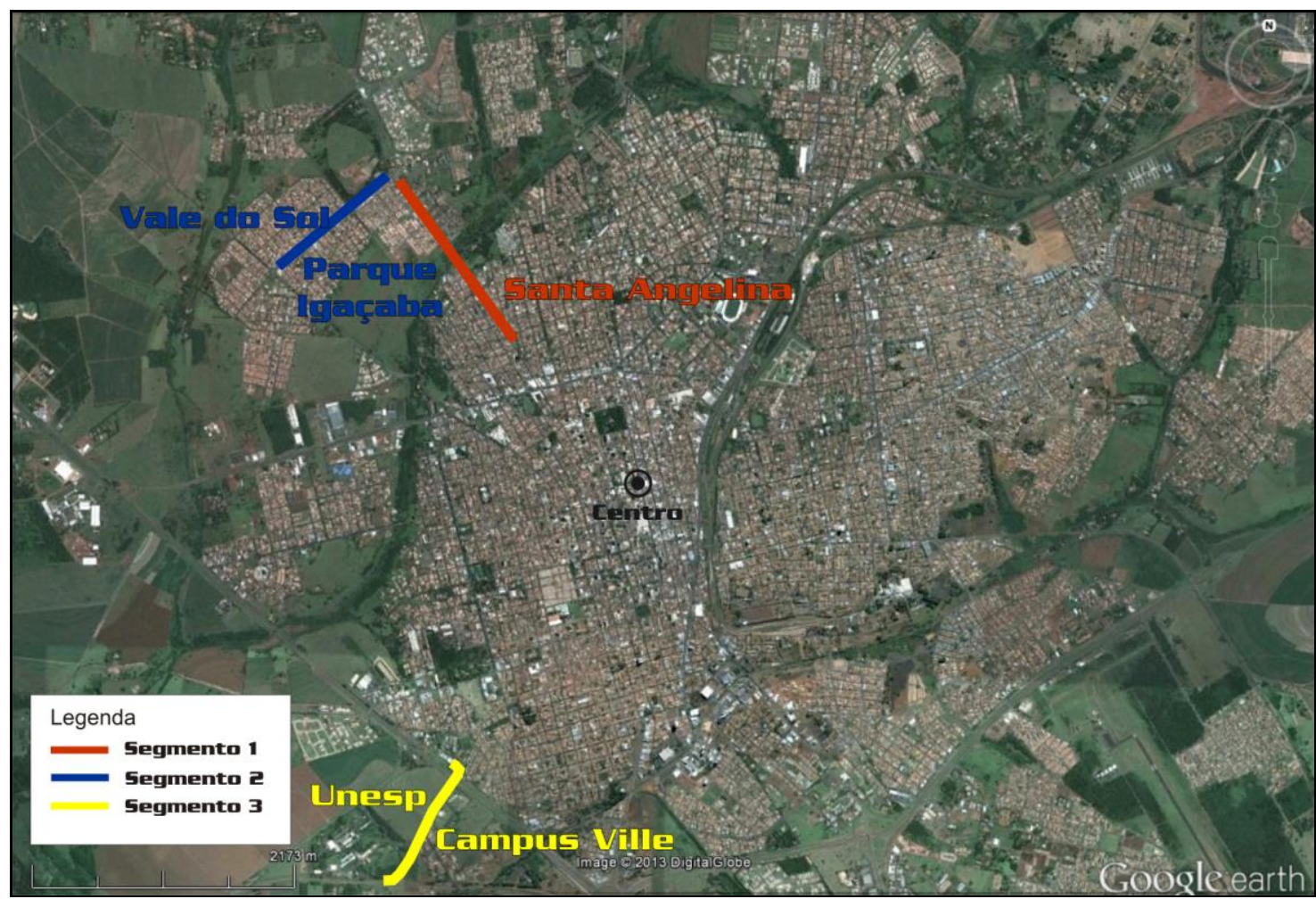

Figura 3.2 - Localização dos segmentos cicloviários de Araraquara. 


\subsection{Caracterização e avaliação do segmento 1}

\section{Caracterização física e operacional}

O segmento 1 consiste de ciclovia com 1.300 metros de extensão e tráfego bidirecional, sendo constituído de três trechos com características distintas.

$\mathrm{Na}$ Figura 3.3 é mostrado o trajeto deste segmento cicloviário com a identificação dos três trechos mencionados.

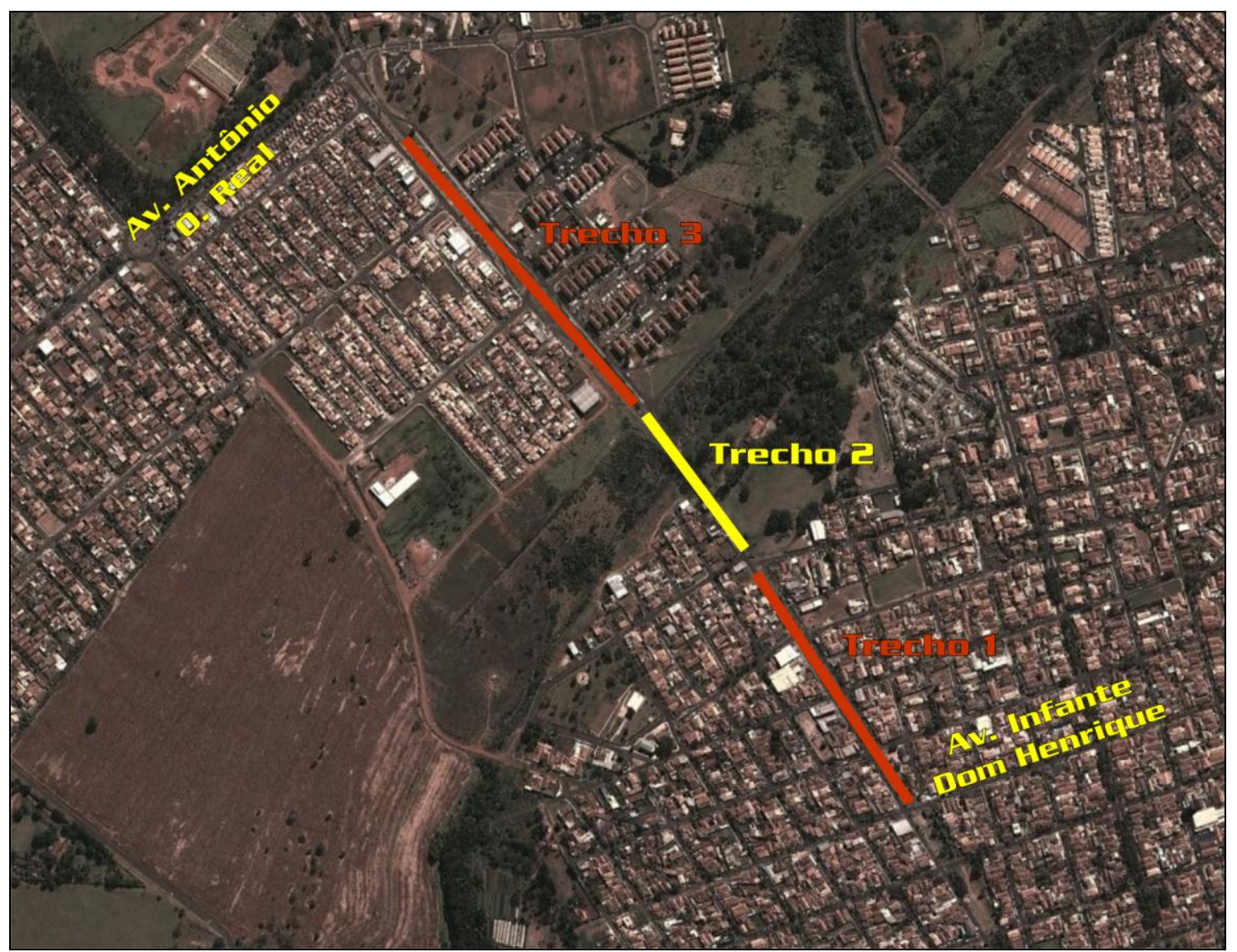

Figura 3.3 - Trajeto do segmento 1.

\section{Trecho 1}

Este trecho corresponde a uma ciclovia bidirecional de 2,70 metros de largura, com extensão de 440 metros e localizado em uma praça linear, entrecortada por ruas, e conformada com guias comuns. Apresenta rampas acentuadas que variam entre 3 e $6 \%$. 
O pavimento é de asfalto e a separação das faixas do tráfego de bicicletas é feito com linha branca; nos cruzamentos com ruas o caminho de passagem das bicicletas é demarcado lateralmente com marcas vermelhas intercaladas.

Na Figura 3.4 é mostrada seção transversal do sistema viário no segmento.

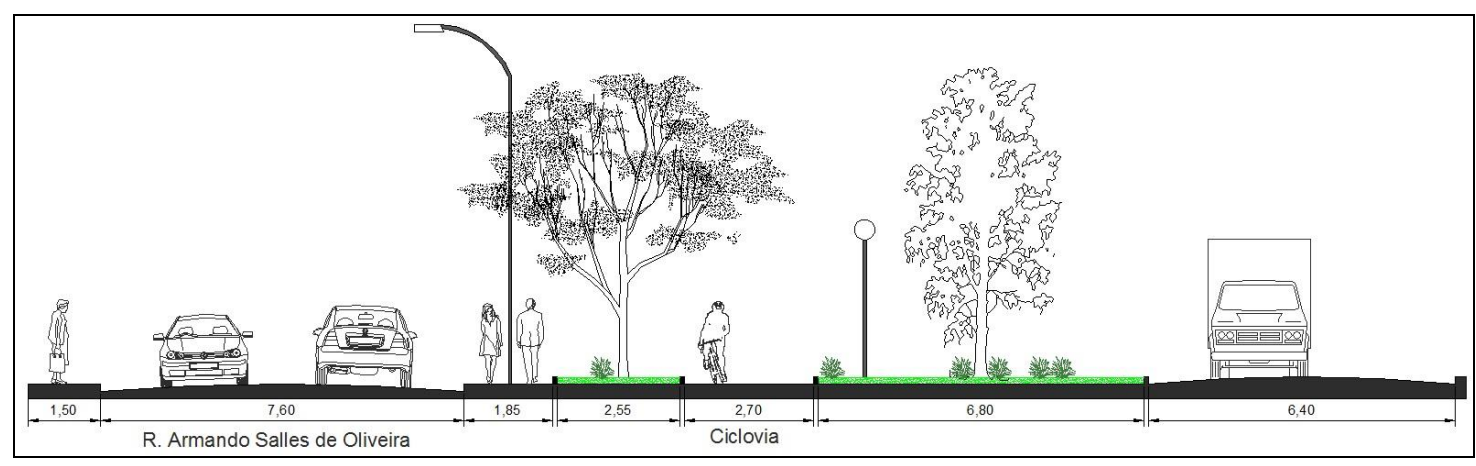

Figura 3.4 - Seção transversal do sistema viário no segmento.

A sinalização vertical é deficiente e as placas existentes se encontram em processo de deterioração.

A sinalização horizontal encontra-se em bom estado na ciclovia, mas está quase que totalmente apagada nos cruzamentos. A linha divisória central que é de cor branca deveria ser de cor amarela.

O estado geral de conservação é ruim, pois há grama invadindo a ciclovia e defeitos no pavimento.

Os ciclistas devem parar em todos os cruzamentos com vias transversais.

Nas Figuras 3.5 a 3.9 são mostrados diferentes aspectos deste segmento.

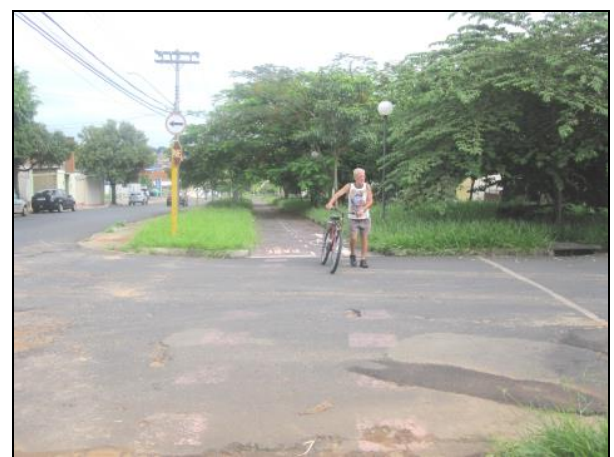

Figura 3.5 - Cruzamento com sinalização horizontal apagada.

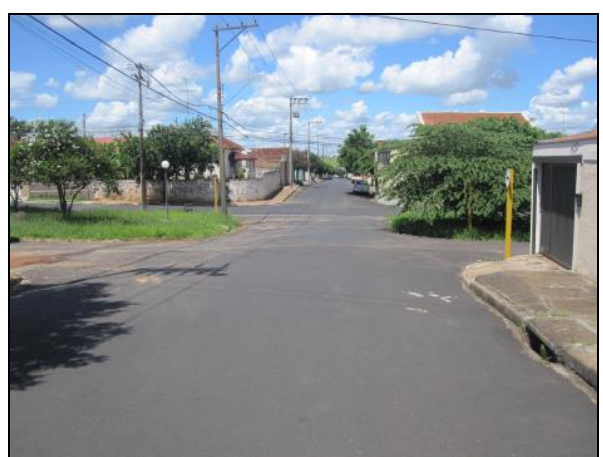

Figura 3.6 - Não existência de placa indicativa de segmento cicloviário à frente. 


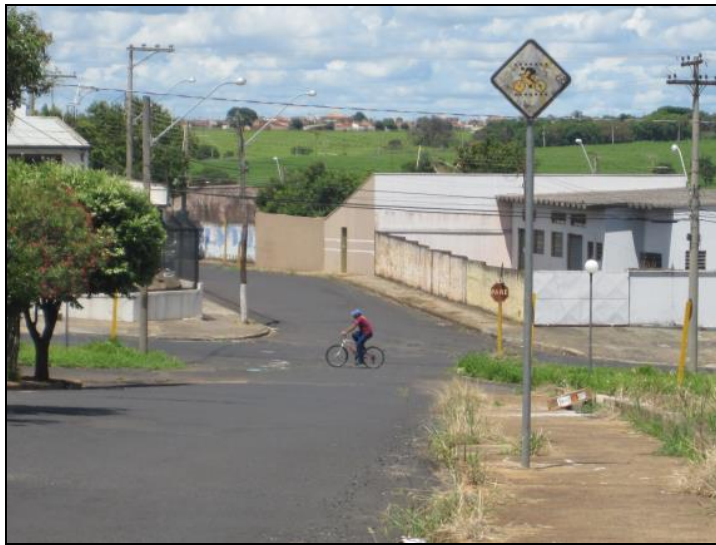

Figura 3.7 - Placa indicativa de cruzamento cicloviário à frente.

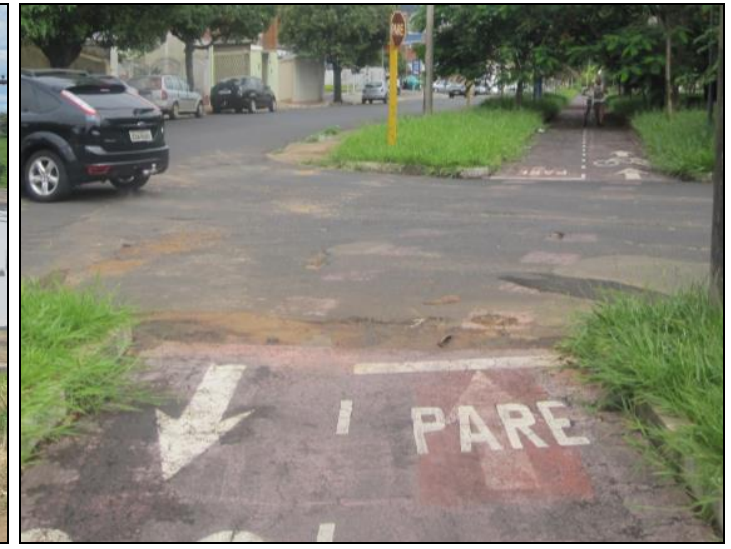

Figura 3.8 - Sinalização horizontal em estado satisfatório na ciclovia e quase totalmente apagada no cruzamento com a rua.

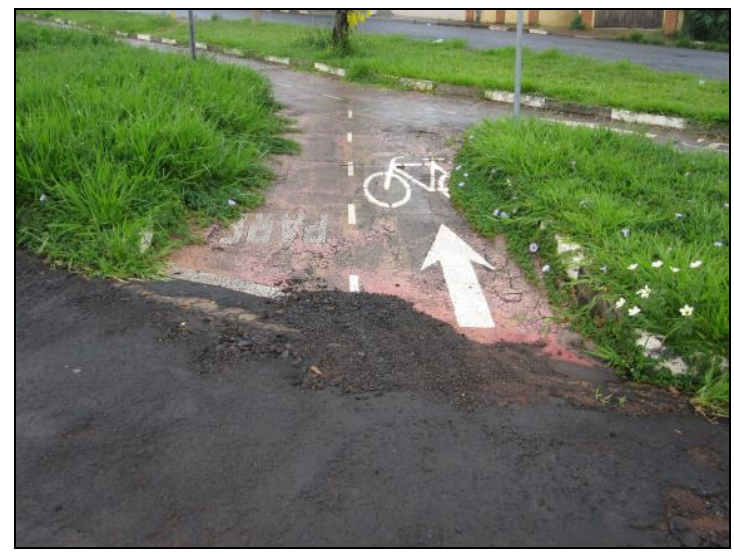

Figura 3.9 - Grama invadindo a ciclovia e calombo no asfalto.

\section{$\underline{\text { Trecho } 2}$}

Neste trecho, conforme mostrado na Figura 3.10, a ciclovia se localiza numa calçada e o tráfego de bicicletas é compartilhado com o tráfego de pedestres, sendo as condições de circulação precárias em razão da pequena largura da calçada (2,0 metros de largura total e 1,4 metros de largura útil em razão da existência de postes). A extensão é de 220 metros e o declive em torno de 5\%.

A calçada é toda pintada de vermelho para indicar a presença da ciclovia, mas a pintura já está bastante desgastada. Não há linha divisória de fluxos. 


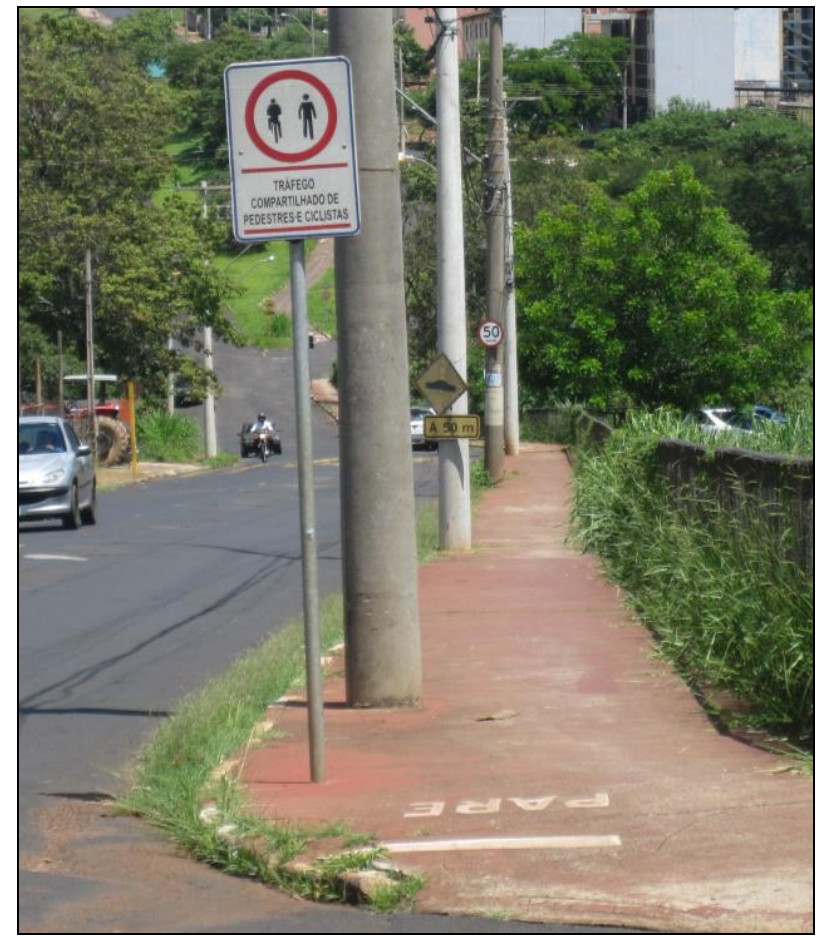

Figura 3.10 - Ciclovia no passeio público.

\section{$\underline{\text { Trecho } 3}$}

Neste trecho, a ciclovia bidirecional tem 2,60 metros de largura e se encontra junto à rua, sendo separada da mesma por guia comum. A inclinação longitudinal varia entre 6 e $8 \%$. A extensão é de 640 metros.

Na Figura 3.11 é mostrada uma visão geral deste trecho.

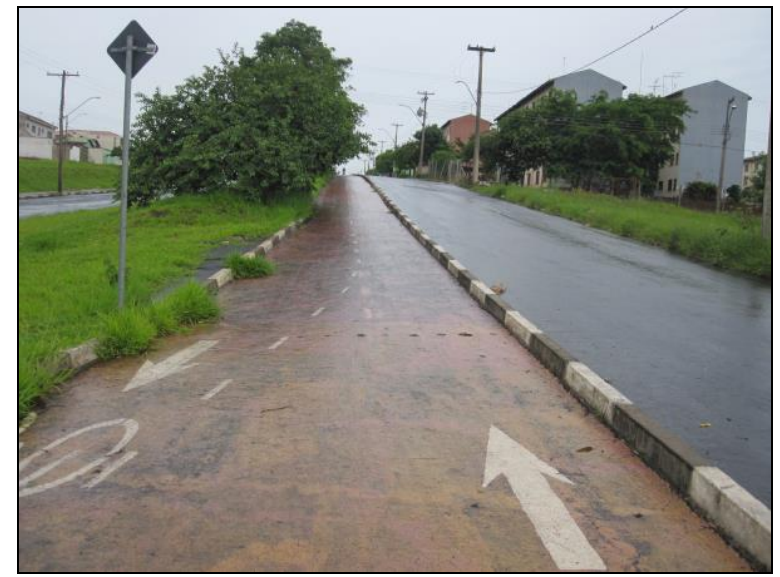

Figura 3.11 - Aspecto geral da ciclovia no trecho 3 . 
A sinalização vertical é deficiente e as placas existentes se encontram em processo de deterioração.

A sinalização horizontal encontra-se em bom estado na ciclovia, mas está quase que totalmente apagada nos cruzamentos. A linha divisória central que é de cor branca deveria ser de cor amarela.

O estado geral de conservação é ruim, pois há grama invadindo a ciclovia e defeitos no pavimento.

Os ciclistas devem parar em todos os cruzamentos com vias transversais.

A implantação da ciclovia reduziu a largura das pistas de 10,00 para 7,40 metros.

\section{$\underline{\text { Fluxo de bicicletas }}$}

As contagens do fluxo do tráfego de bicicletas foram realizadas nos períodos de maior movimento: de manhã, das 06:30 às 09:00, no meio do dia, das 11:30 às 13:30, e à tarde, das 17:00 às 19:00. Na Tabela 3.2 estão relacionados os valores dos fluxos horários encontrados.

Tabela 3.2 - Valores do volume horário (bicicleta/hora).

\begin{tabular}{ccccccccc}
\hline \multicolumn{3}{c}{ Na ciclovia* } & \multicolumn{3}{c}{ Fora da ciclovia* } & \multicolumn{3}{c}{ Total } \\
\hline Manhã & $\begin{array}{c}\text { Meio } \\
\text { do dia }\end{array}$ & Tarde & Manhã $\begin{array}{c}\text { Meio } \\
\text { do dia }\end{array}$ & Tarde & Manhã & $\begin{array}{c}\text { Meio } \\
\text { do dia }\end{array}$ & Tarde \\
\hline 6,0 & $\begin{array}{c}6,0 \\
\text { Média }=8,0\end{array}$ & 12,0 & 4,8 & 6,5 & 10,5 & 10,8 & 12,5 & 22,8 \\
Média $=7,3$ & & Média $=15,3$ & \\
\hline
\end{tabular}

${ }^{*} \mathrm{~A}$ quase totalidade dos ciclistas empurram as bicicletas nos trechos em rampa acentuada (sentido bairro-centro nos trechos 1 e 2 e sentido centrobairro no trecho 3 ).

Os valores da Tabela 3.2 permitem inferir que:

- O número de ciclistas é pequeno; em média, nos horários de maior movimento, uma bicicleta a cada 3,9 minutos.

- $52,3 \%$ utilizam a ciclovia e $47,7 \%$ não utilizam. 


\section{Pesquisa com ciclistas}

Dos dez ciclistas entrevistados que utilizavam a ciclovia, oito (80\%) disseram que usavam a bicicleta para passear e/ou fazer exercícios e dois $(20 \%)$ por outro motivo (trabalhar, estudar, fazer compras, encontrar com amigos, etc.). Todos reclamaram da necessidade de parar em todos os cruzamentos e dar preferência aos veículos que cruzam a ciclovia.

Dos dez ciclistas que não utilizavam a ciclovia, dois (20\%) disseram que usavam a bicicleta para passear e/ou fazer exercícios e oito $(80 \%)$ por outro motivo (trabalhar, estudar, fazer compras, encontrar com amigos, etc.). Todos $(100 \%)$ alegaram que era mais seguro e mais rápido utilizar a direita da via e não a ciclovia, pois era menos perigoso passar nas interseções e não tinham que parar nos cruzamentos para dar a preferência a outros veículos.

\section{Pesquisa com moradores da vizinhança}

Dos dez moradores da vizinhança entrevistados, nove (90\%) responderam que não foi importante a Prefeitura ter implantado a ciclovia, uma vez que ela tem pouco uso, e que os recursos deveriam ter sido empregados em outros benefícios para a região.

Um deles (10\%) respondeu que foi importante, mas que ela necessita de melhorias.

\section{Avaliação do segmento}

Os seguintes pontos são relevantes no tocante ao segmento 1:

- Apesar de não constituir um investimento de grande valor, a implantação da ciclovia é questionável do ponto de vista socioeconômico uma vez que o tráfego de bicicletas no trecho do sistema viário onde ela se situa é muito pequeno.

- A implantação da ciclovia é questionável sob a ótica política, pois a maioria dos moradores da vizinhança não aprova a obra. 
- A visão da minoria dos moradores que aprovam a ciclofaixa é que ela constitui um espaço para a prática de exercícios e de lazer e não para deslocamentos por motivo de trabalho, estudo, compras, etc. - o que se comprova na prática, pois a maioria dos usuários utiliza a mesma para a prática de exercícios e de lazer.

- O projeto de ciclovia bidirecional no canteiro central não atende às aspirações dos usuários que se deslocam por motivo de trabalho, estudo, compras, etc., pois esses, na sua maioria, por razões de segurança e praticidade, optam por trafegar do lado direito das pistas do tráfego motorizado.

- O impacto no trânsito geral é pequeno, pois o volume de veículos no trecho em que a largura da via foi reduzida é pequeno e as bicicletas são obrigadas a parar em todos os cruzamentos com veículos.

- As condições do pavimento, a sinalização e a conservação são insatisfatórias.

\subsection{Caracterização e avaliação do segmento 2}

\section{Caracterização física e operacional}

Trata-se de ciclovia bidirecional situada no canteiro central da Avenida Antônio Honório Real com extensão de 1.000 metros. 


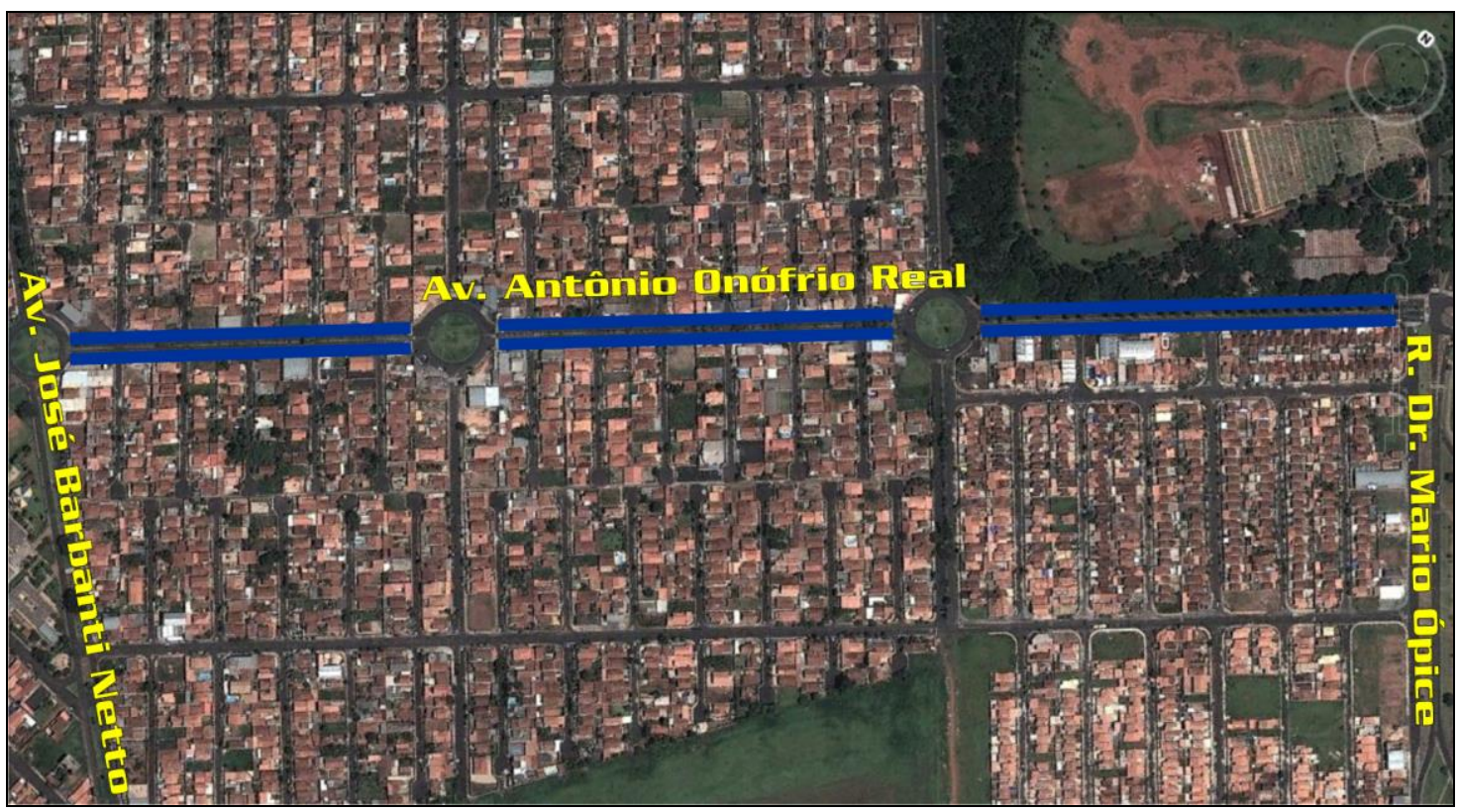

Figura 3.12 - Trajeto do segmento 2.

A ciclovia é constituída de duas vias com fluxo unidirecional, ambas com largura de 1,40 metros e segregadas da via comum por meio de guia comum. Na Figura 3.13.é mostrada a seção transversal do sistema viário neste trecho.

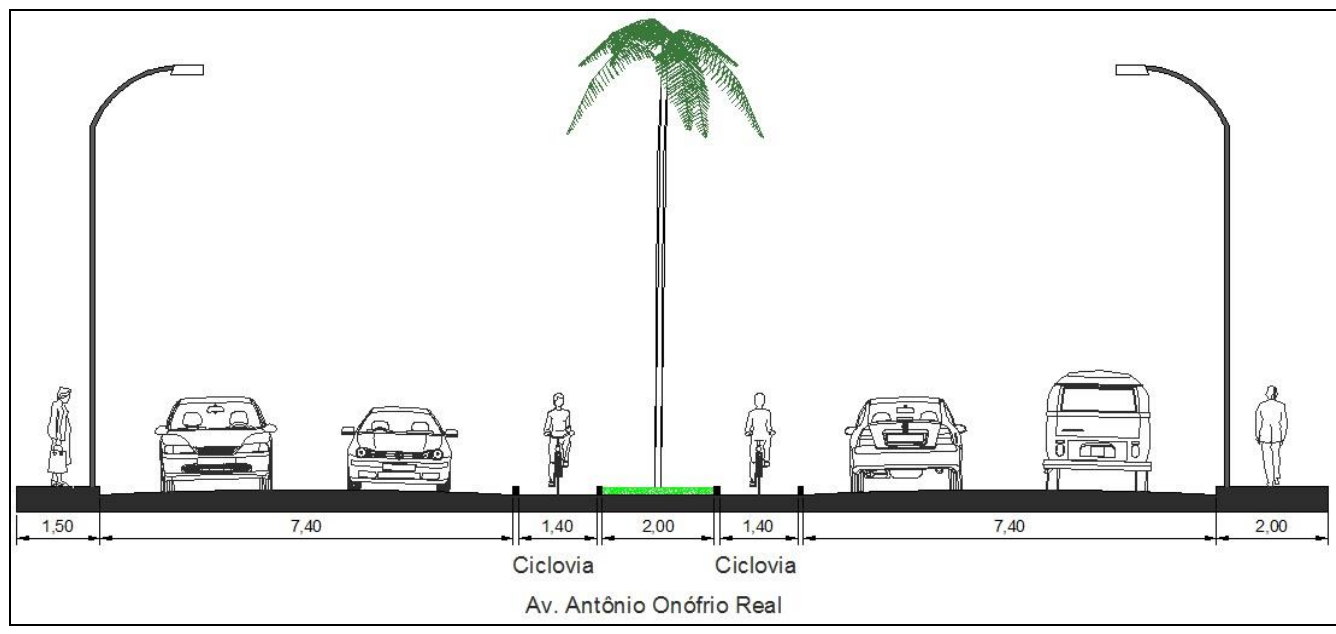

Figura 3.13 - Seção transversal do sistema viário no segmento.

O trecho é quase plano, com a declividade das rampas variando entre 0 e $2 \%$.

A sinalização vertical é deficiente e as placas existentes se encontram em processo de deterioração. 
Há inúmeros cruzamentos com vias transversais sem sinalização adequada, o que torna perigosa e confusa a operação por duas razões: não está claro quem tem a preferência e os demais veículos não são informados da passagem de bicicletas no local - alerta importante para os veículos que cruzam a via onde se localiza a ciclovia e aqueles que fazem conversão à esquerda.

O estado de conservação é insatisfatório, pois há grama invadindo a ciclovia e pequenos defeitos no pavimento.

Um problema deste segmento é a total descontinuidade da ciclovia nos cruzamentos com rotatórias. Não há sinalização horizontal indicando 0 "caminho" aos ciclistas e a presença de bicicletas em movimento aos outros usuários da via e nem sinalização vertical de apoio; fato que torna complicado o trânsito no local prejudicando a comodidade e a segurança dos usuários.

A implantação da ciclovia reduziu a largura das pistas de 9,00 para 7,40 metros. Como há estacionamento do lado direito das pistas, a presença de caminhões e ônibus no trânsito reduz de duas para uma o número de faixas de tráfego.

Nas Figuras 3.14 e 3.15 são mostrados diferentes aspectos deste segmento cicloviário.

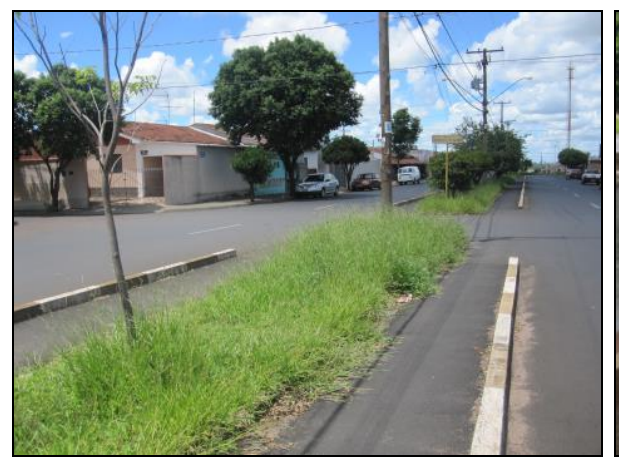

Figura 3.14 - Inexistência de sinalização horizontal indicativa da presença de ciclovia em cruzamentos.

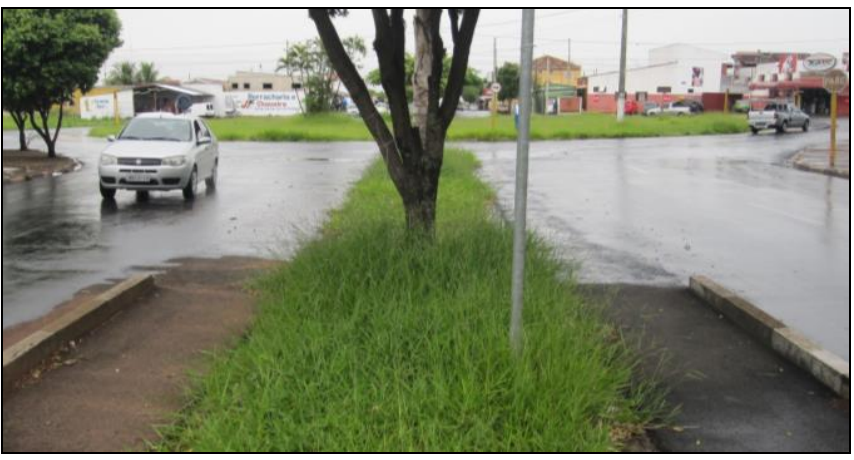

Figura 3.15 - Inexistência de sinalização horizontal indicativa do "caminho" para os ciclistas em rotatórias 


\section{$\underline{\text { Fluxo de bicicletas }}$}

As contagens do fluxo do tráfego de bicicletas foram realizadas nos períodos de maior movimento: de manhã, das 06:30 às 09:00 h, no meio do dia, das 11:30 às 13:30, e à tarde, das 17:00 às 19:00 h. Na Tabela 3.3 estão relacionados os valores dos fluxos horários encontrados.

Tabela 3.3 - Valores do volume horário (bicicleta/hora).

\begin{tabular}{ccccccccc}
\hline \multicolumn{3}{c}{ Na ciclovia } & \multicolumn{3}{c}{ Fora da ciclovia } & \multicolumn{2}{c}{ Total } & \\
\hline Manhã & $\begin{array}{c}\text { Meio } \\
\text { do dia }\end{array}$ & Tarde & Manhã $\begin{array}{c}\text { Meio } \\
\text { do dia }\end{array}$ & Tarde & Manhã & $\begin{array}{c}\text { Meio } \\
\text { do dia }\end{array}$ & Tarde \\
\hline 9,6 & 10,5 & 13,5 & 18,2 & 28,0 & 40,5 & 27,8 & 38,5 & 54,0 \\
Média $=11,2$ & & \multicolumn{2}{c}{ Média $=28,9$} & \multicolumn{3}{c}{ Média $=40,1$} & \\
\hline
\end{tabular}

Os valores da Tabela 3.3 permitem inferir que:

- O número de ciclistas é pequeno; em média, nos horários de maior movimento, uma bicicleta a cada 1,5 minutos.

- $27,9 \%$ utilizam a ciclovia e $72,1 \%$ não utilizam.

\section{Pesquisa com ciclistas}

Dos dez ciclistas entrevistados que utilizavam a ciclovia, seis (60\%) disseram que usavam a bicicleta para passear e/ou fazer exercícios e quatro (40\%) por outro motivo (trabalhar, estudar, fazer compras, encontrar com amigos, etc.). Muitos reclamaram da falta de sinalização adequada nos cruzamentos, fato que quase sempre os obrigava a parar e dar a preferência aos veículos motorizados em cruzavam via ou faziam conversão à esquerda.

Dos dez ciclistas que não utilizavam a ciclovia, sete (70\%) disseram que usavam a bicicleta para passear e/ou fazer exercícios e três (30\%) por outro motivo (trabalhar, estudar, fazer compras, encontrar com amigos, etc.). Todos (100\%) alegaram que era mais seguro e mais rápido utilizar a direita da via e não a ciclovia, pois era mais seguro e não tinham que parar nos cruzamentos para dar a preferência a outros veículos.

\section{Pesquisa com moradores da vizinhança}


Dos dez moradores da vizinhança entrevistados, oito (80\%) responderam que não foi importante a Prefeitura ter implantado a ciclovia, uma vez que ela tem pouco uso, e que os recursos deveriam ter sido empregados em outros benefícios para a região.

Dois moradores (20\%) responderam que foi importante, mas que ela necessita de melhorias nos cruzamentos.

\section{Avaliação do segmento}

Os seguintes pontos são relevantes no tocante ao segmento 2:

- Apesar de não constituir um investimento de grande valor, a implantação da ciclovia é questionável do ponto de vista socioeconômico uma vez que o tráfego de bicicletas no trecho do sistema viário onde ela se situa é muito pequeno.

- A implantação da ciclovia é questionável sob a ótica política, pois a maioria dos moradores da vizinhança não aprova a obra.

- A maioria dos ciclistas utiliza a ciclovia para a prática de exercícios e de lazer.

- O projeto de ciclovia unidirecional junto ao canteiro central não atende, tecnicamente, às aspirações dos ciclistas, uma vez que, por razões de segurança e praticidade, eles optam por trafegar do lado direito das pistas do tráfego motorizado.

- O impacto no trânsito é pequeno, pois o volume de veículos no trecho em que a largura da via foi reduzida é pequeno e as bicicletas são obrigadas a parar em todos os cruzamentos.

- As condições do pavimento, a sinalização e a conservação são insatisfatórias.

\subsection{Caracterização e avaliação do segmento 3}




\section{Caracterização física e operacional}

Consiste de ciclovia bidirecional situada ao lado de um dos acostamentos da Av. Alberto Toloi, que tem características de "rodovia". Tem início na Rua Prof. Francisco Degni, defronte ao Instituto de Química da UNESP, e termina na entrada do Campus Universitário da UNESP.

A ciclovia é conformada por guias comuns, tem largura de 2,70 metros, extensão de 1.030 metros e situa-se em terreno praticamente plano. $O$ revestimento é de asfalto.

No "início" da ciclovia na Rua Francisco Degni, em frente ao Instituto de Química da UNESP, e no "fim" na entrada do Campus da UNESP, ela também é separada do tráfego normal de veículos por guia comum.

No viaduto sobre a Rodovia SP-310, a ciclovia é segregada do tráfego geral por meio de uma estrutura de concreto com cerca de $1 \mathrm{~m}$ de altura.

Como não há passeio em nenhum dos dois lados da rua, o espaço da ciclovia também é utilizado por pedestres (alguns poucos pedestres preferem utilizar a margem oposta gramada).

Na Figura 3.16 é indicado o trajeto deste segmento cicloviário.

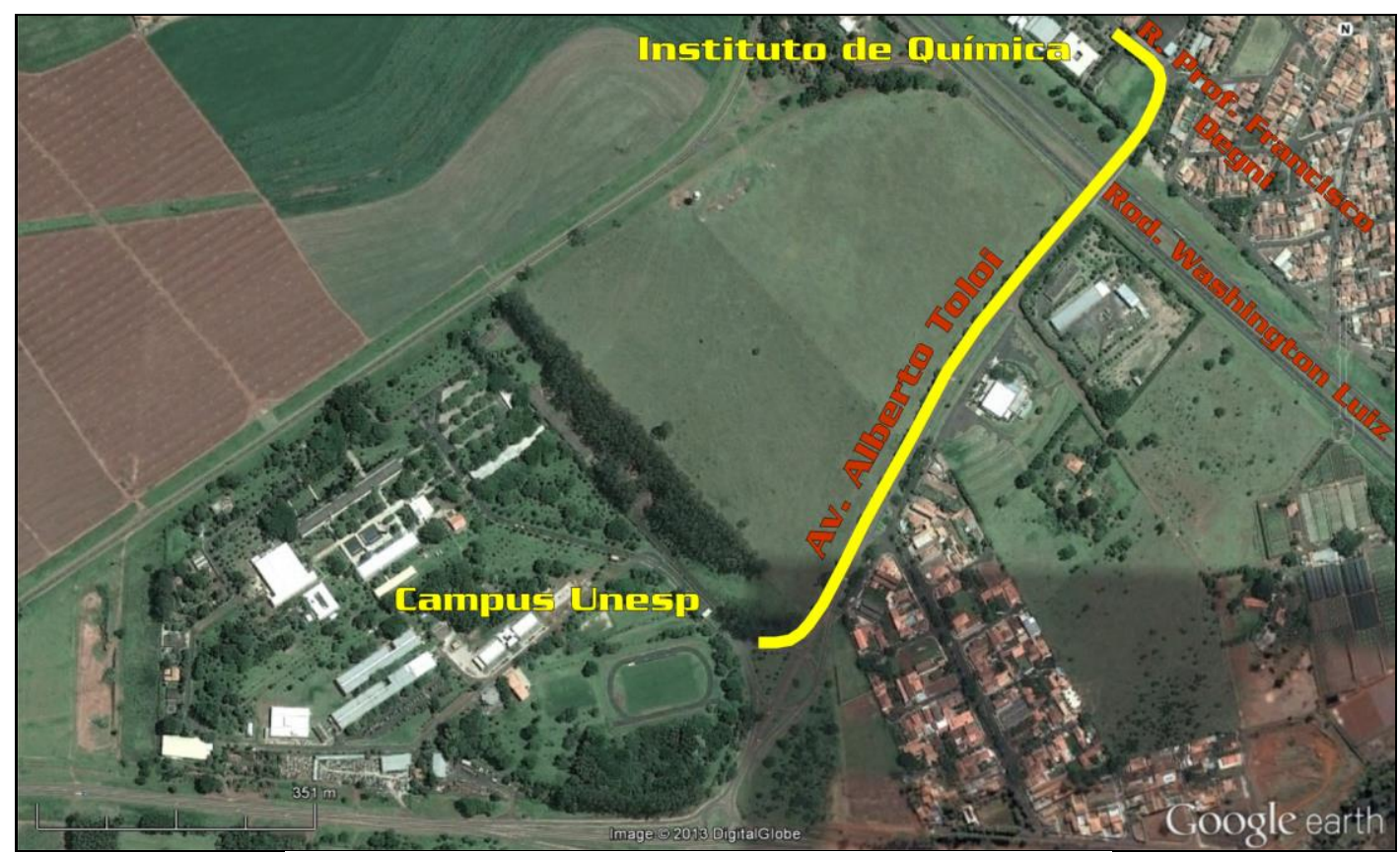

Figura 3.16 - Trajeto do segmento 3. 
As placas de sinalização vertical se encontram em processo de deterioração.

Não há sinalização vertical e horizontal indicando o fim da ciclovia nos dois extremos.

A sinalização horizontal se mostra adequada no geral, mas ruim em um pequeno trecho em razão do aparecimento de marca antiga de sinalização viária.

Como não há cruzamentos com outras vias, os ciclistas se deslocam sem necessidade de parar para dar passagem a outros veículos ou pedestres.

O estado geral de conservação da ciclovia é bom.

Com a implantação da ciclovia foi eliminado o estacionamento de veículos em frente ao Instituto de Química no final da Rua Francisco Degni.

Nas Figuras 3.17 a 3.24 são mostradas diferentes aspectos deste segmento.

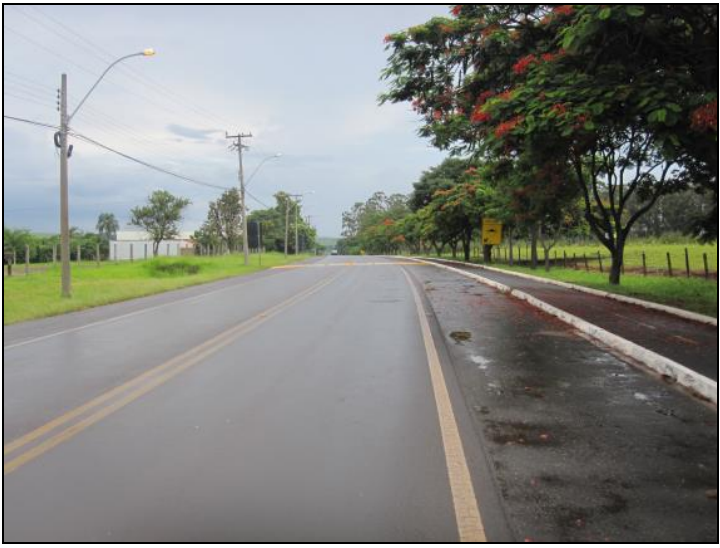

Figura 3.17 - Posição da ciclovia em relação à rua.

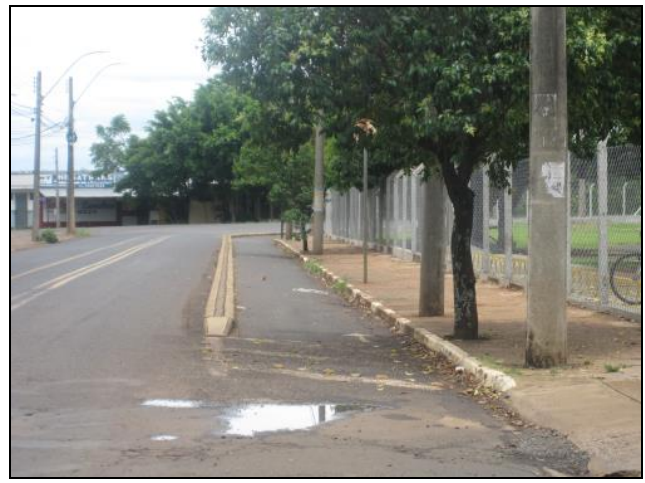

Figura 3.19 - Extremidade da ciclovia junto ao Instituto de Química.

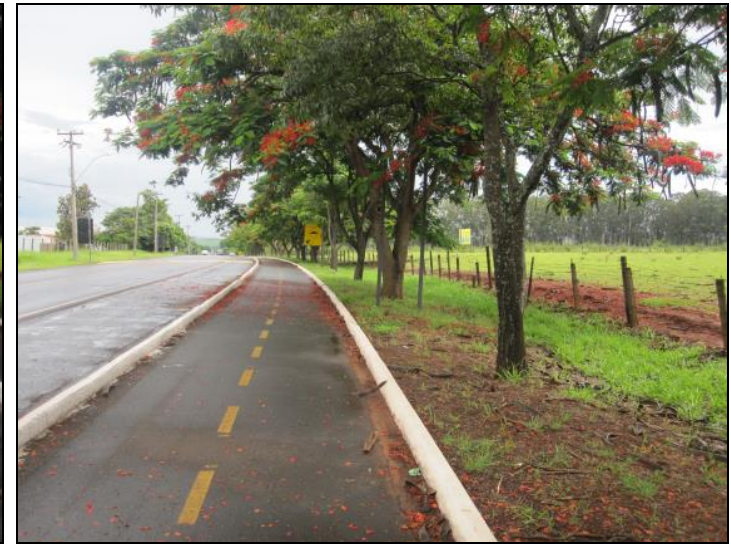

Figura 3.18 - Vista geral da ciclovia.

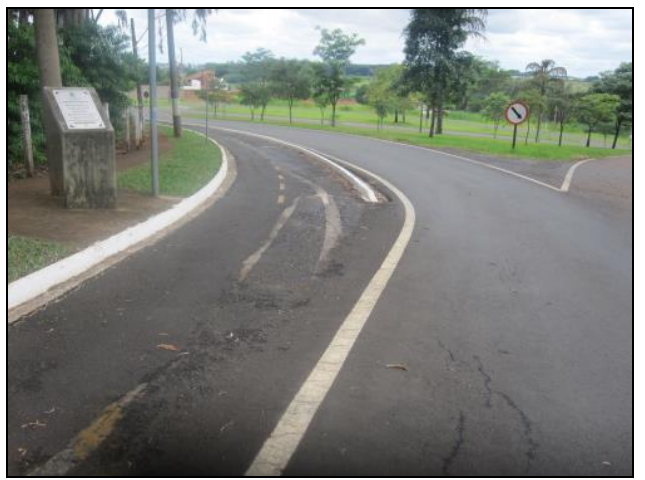

Figura 3.20 - Extremidade da ciclovia junto ao Campus da UNESP. 


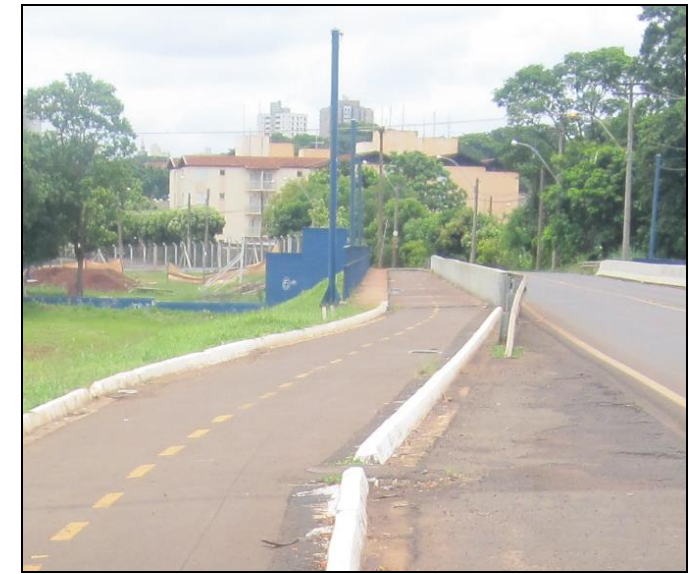

Figura 3.21 - Estrutura de separação da ciclovia no viaduto.

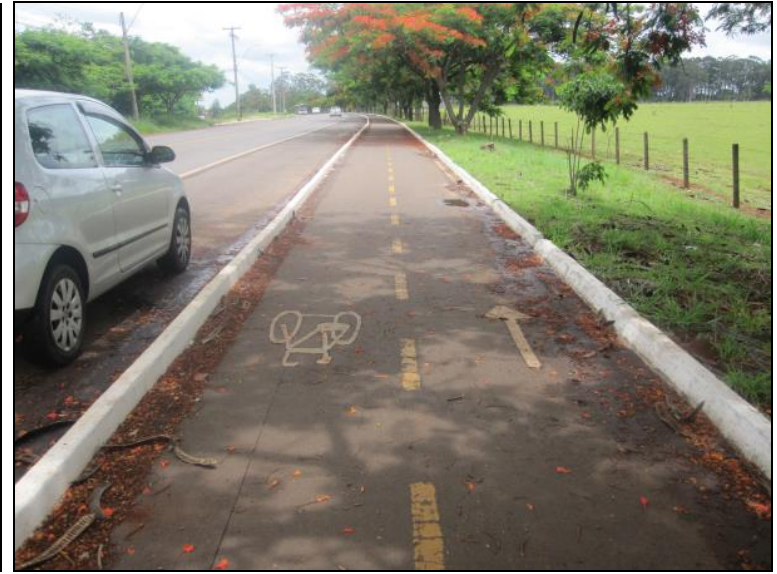

Figura 3.22 - Trecho com sinalização horizontal adequada.

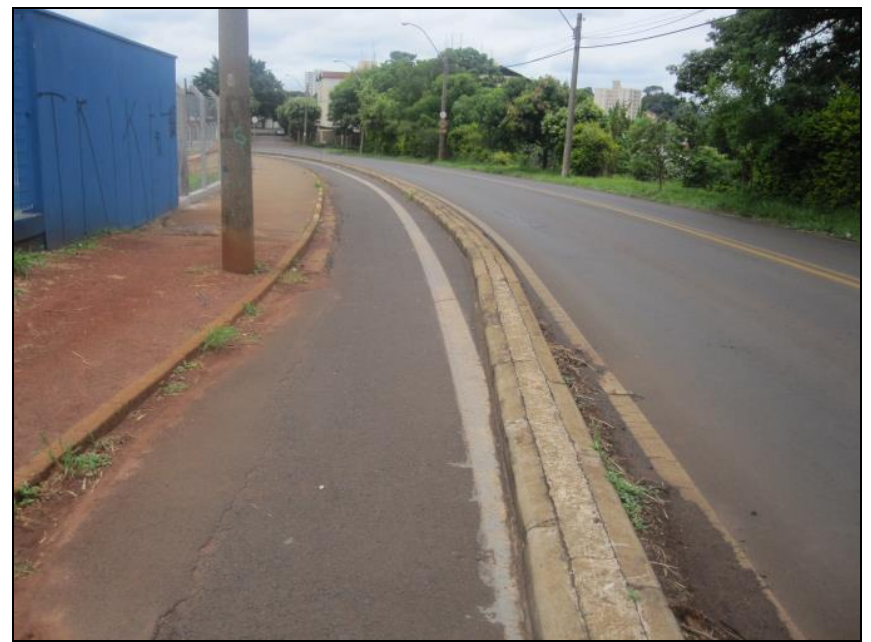

Figura 3.23 - Trecho com sinalização horizontal inadequada: sem linha divisória de fluxos e com marca antiga de sinalização anterior a implantação da ciclovia.

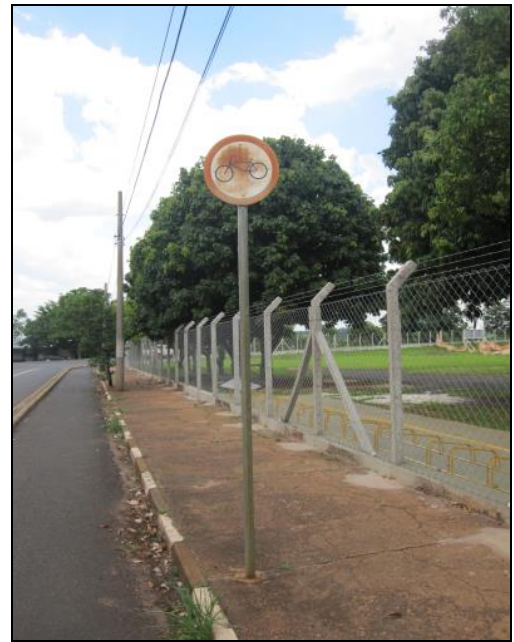

Figura 3.24 - Placa de sinalização vertical deteriorada.

\section{Fluxo de bicicletas}

As contagens do fluxo do tráfego de bicicletas foram realizadas nos períodos de maior movimento: de manhã, das 06:30 às 09:00 h, no meio do dia, das $11: 30$ às 13:30, e à tarde, das 17:00 às 19:00 h. Na Tabela 3.4 estão relacionados os valores dos fluxos horários encontrados. 
Tabela 3.4 - Valores do volume horário (bicicleta/hora).

\begin{tabular}{|c|c|c|c|c|c|c|c|c|}
\hline \multicolumn{3}{|c|}{ Na ciclovia } & \multicolumn{3}{|c|}{ Fora da ciclovia } & \multicolumn{3}{|c|}{ Total } \\
\hline Manhã & $\begin{array}{c}\text { Meio } \\
\text { do dia }\end{array}$ & Tarde & Manhã & $\begin{array}{l}\text { Meio } \\
\text { do dia }\end{array}$ & Tarde & Manhã & $\begin{array}{c}\text { Meio } \\
\text { do dia }\end{array}$ & Tarde \\
\hline 3,6 & 2,5 & 9,0 & 0,4 & 0,0 & 2,0 & 4,0 & 2,5 & 11,0 \\
\hline \multicolumn{3}{|c|}{ Média $=5,0$} & \multicolumn{3}{|c|}{ Média $=0,8$} & \multicolumn{3}{|c|}{ Média $=5,8$} \\
\hline
\end{tabular}

Os valores da Tabela 3.4 permitem inferir que:

- O número de ciclistas é muito pequeno; em média, nos horários de maior movimento, uma bicicleta a cada 10,3 minutos.

- $86,2 \%$ utilizam a ciclovia e $13,8 \%$ não utilizam.

\section{$\underline{\text { Pesquisa com ciclistas }}$}

Dos dez ciclistas que utilizavam a ciclovia, nove ( $90 \%$ ) disseram que usavam a bicicleta para trabalhar ou estudar e um (10\%) para passear e fazer exercícios. Muitos deles reclamaram da presença de pedestres na ciclovia.

Não foram entrevistados ciclistas que não utilizavam a ciclovia, pois a quantidade é ínfima.

\section{Pesquisa com moradores da vizinhança}

Todos os dez moradores da vizinhança entrevistados, portanto $100 \%$, responderam que não foi importante a Prefeitura ter implantado a ciclovia, pois ela tem baixíssimo uso sendo utilizada praticamente apenas por pedestres uma vez que não há calçada na via. Disseram, também, que os recursos deveriam ter sido utilizados na construção de calçadas.

\section{Avaliação do segmento}

Os seguintes pontos são relevantes no tocante ao segmento 3:

- A implantação da ciclovia é questionável do ponto de vista socioeconômico, uma vez que o tráfego de bicicletas no trecho do sistema viário onde ela se situa é muito pequeno. 
- A implantação da ciclovia é questionável do ponto de vista político, pois a maioria dos moradores da vizinhança não aprova a obra.

- A maioria absoluta dos ciclistas utiliza a ciclovia para deslocamentos por motivo de motivo de trabalho e estudo.

- Não há impacto no trânsito, pois a ciclovia se situa ao lado da "rodovia".

- As condições do pavimento, a sinalização e a conservação da ciclovia são satisfatórias.

\subsection{Avaliação geral do sistema cicloviário de Araraquara}

Com relação ao sistema cicloviário de Araraquara, as seguintes observações são pertinentes:

- A implantação dos três segmentos é questionável do ponto de vista socioeconômico, uma vez que o tráfego de bicicletas em todos eles é muito pequeno.

- A implantação dos três segmentos é questionável sob a ótica política, pois a maioria dos moradores da vizinhança não aprova a ciclovia/ciclofaixa.

- Os segmentos 1 e 2 apresentam problemas técnicos graves que levam os ciclistas a trafegar do lado direito das pistas comuns de tráfego, não utilizando a ciclovia/ciclofaixa por razões de segurança e praticidade.

- O segmento 1 tem o seu desempenho prejudicado pela existência de rampa acentuada em grande parte da sua extensão.

- Há trechos dos segmentos 1 e 2 onde a existência da ciclovia traz prejuízo para o trânsito geral.

- De maneira geral, as condições do pavimento, a sinalização e a conservação dos três segmentos são insatisfatórias.

Os seguintes índices globais são verificados em Araraquara: 
- População = 222.036 habitantes.

- Extensão do sistema cicloviário $=6.660$ metros de ciclovia/ciclofaixa (considerando em separado cada sentido de fluxo).

- Soma dos valores médios dos fluxos de bicicletas nos períodos de maior movimento nas vias onde se localizam os segmentos cicloviários $=61,20$ bicicletas por hora.

- Relação entre a extensão do sistema cicloviário e a população $=30,00$ metros de ciclovia/ciclofaixa por mil habitantes.

- Relação entre a soma dos fluxos de bicicletas e a população $=27,56$ bicicletas por hora por cem mil habitantes.

- Relação entre a soma dos fluxos de bicicletas e a extensão do sistema cicloviário = 9,19 bicicletas por hora por km de ciclovia/ciclofaixa.

Esses valores quando comparados com os das outras cidades estudadas (São Carlos e Rio Claro) permite fazer as seguintes inferências:

- Araraquara tem a menor extensão do sistema cicloviário: São Carlos tem 2,30 vezes mais e Rio Claro, 2,71.

- Araraquara tem a menor soma dos fluxos de bicicletas: São Carlos tem 1,76 vezes mais e Rio Claro, 11,11.

- Araraquara tem a menor relação entre a extensão do sistema viário e a população: São Carlos tem 2,16 vezes mais e Rio Claro, 3,05.

- Araraquara tem a menor relação entre a soma dos fluxos de bicicletas e a população: São Carlos tem 1,66 vezes mais e Rio Claro, 12,54.

- Araraquara tem posição intermediária no tocante à relação entre a soma dos fluxos de bicicletas e a extensão do sistema cicloviário: São Carlos tem 1,30 vezes menos e Rio Claro, 4,11 vezes mais. 


\section{4- CARACTERIZAÇÃo E AVALIAÇÃo DO SISTEMA CICLOVIÁRIO DE SÃO CARLOS}

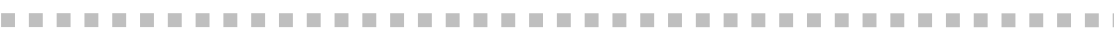

\subsection{Informações gerais do município}

O município de São Carlos está localizado na região central do Estado de São Paulo e conta com uma população de 236.457 habitantes. A cidade encontrase a uma distância rodoviária de 230 km de São Paulo, capital do Estado.

Na Tabela 4.1 são relacionados alguns dados gerais relativos ao município.

Tabela 4.1 - Dados gerais do município de São Carlos. Fonte: IBGE (2013), DENATRAN (2013).

\begin{tabular}{lc}
\hline População & $\mathbf{2 3 6 . 4 5 7}$ \\
\hline Índice de Desenvolvimento Humano Municipal - IDHM & $\mathbf{0 , 8 0 5}$ \\
\hline Renda per capita (em reais correntes) & $\mathbf{9 2 3 , 6 2}$ \\
\hline Frota Veicular & $\mathbf{1 5 3 . 1 6 1}$ \\
\hline Índice de Motorização & $\mathbf{6 4 , 7 7}$ \\
Índice de Gini* & $\mathbf{0 , 4 9 8 6}$ \\
\hline *Índice de Gini da renda domiciliar per capita (quanto mais próximo de \\
zero maior a distribuição da renda; quanto mais próximo de 1 menor a \\
distribuição da renda).
\end{tabular}

A estrutura urbana da cidade é do tipo radial-concêntrica, sendo que a maior parte de consumo de bens e serviços está localizada no centro ou ao longo das vias que interligam a região central com bairros periféricos. A cidade possui uma topografia acidentada, principalmente no centro, onde se encontra 0 Córrego do Gregório (fundo de vale).

Na Figura 4.1 é mostrado mapa da cidade com as principais vias. 


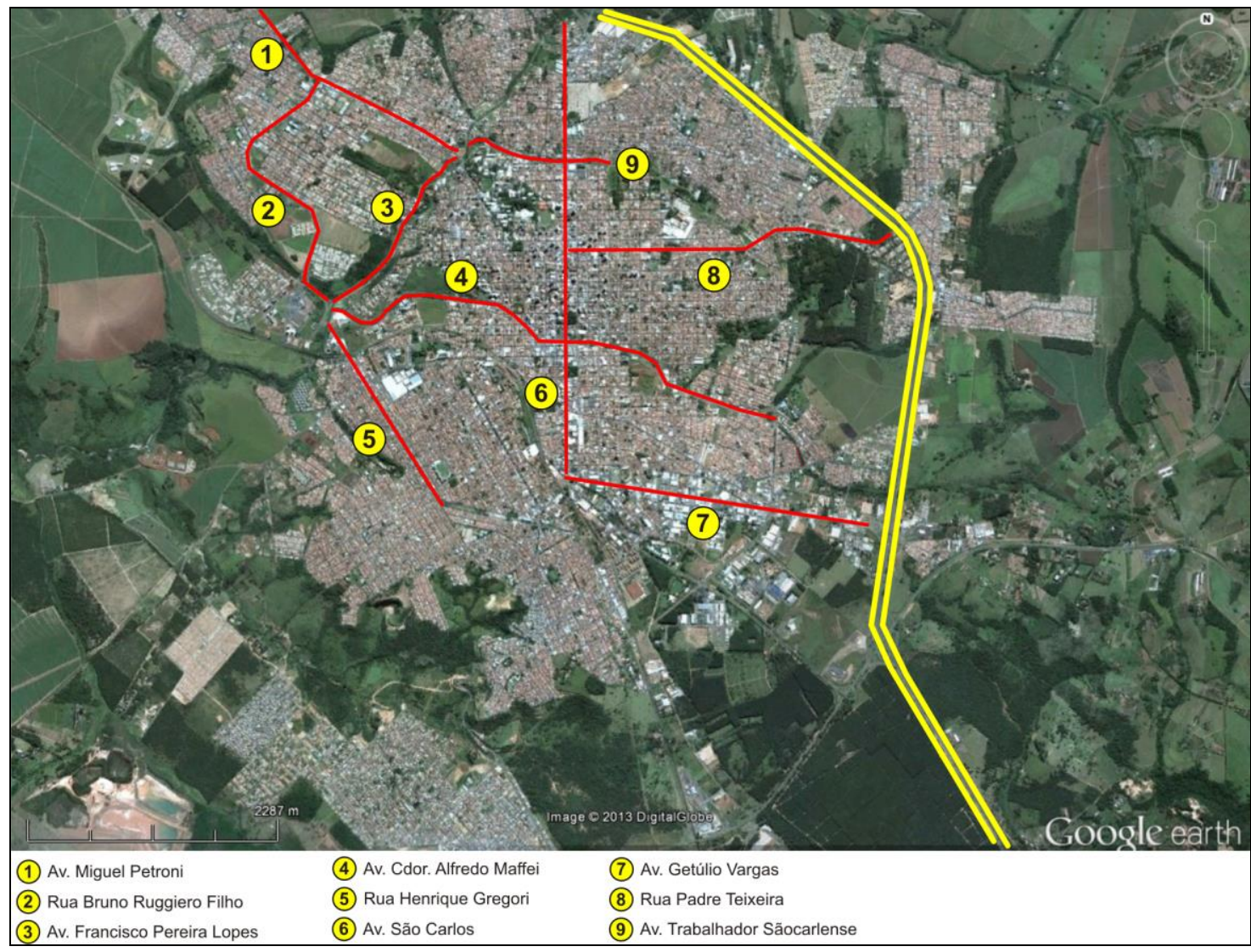

Figura 4.1 - Mapa com as principais vias da cidade de São Carlos.

A bicicleta é pouco utilizada como meio de transporte, possivelmente em razão da topografia acidentada e do nível de renda elevado da população. Segundo FIPAI (2008), em São Carlos apenas 3\% das pessoas declararam usar bicicleta para se deslocar de um lugar a outro.

$\mathrm{Na}$ Figura 4.2 são mostrados os números relativos à divisão modal no transporte urbano da cidade.

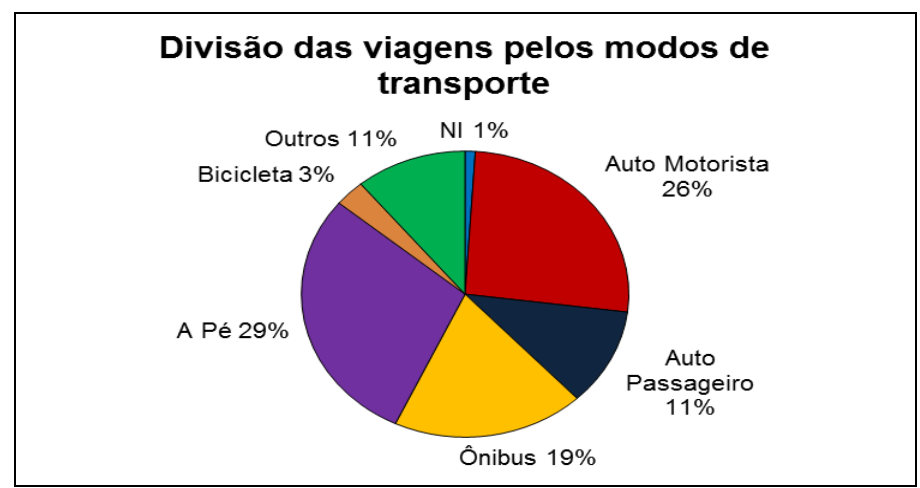

Figura 4.2 - Divisão modal das viagens em São Carlos.

Fonte: FIPAI, 2008. 


\subsection{Sistema Cicloviário}

O sistema cicloviário de São Carlos tem 7.650 metros de extensão (15.300 metros considerando em separado cada sentido), sendo constituído dos seguintes sete segmentos:

- Segmento 1 - Ciclofaixa bidirecional situada em uma das pistas da Av. Francisco Pereira Lopes; tem extensão de 1.000 metros.

- Segmento 2 - Ciclovia bidirecional situada no canteiro central da Rua Henrique Gregori; tem extensão de 1.130 metros.

- Segmento 3 - Ciclofaixa bidirecional situada em uma das pistas da Avenida Comendador Alfredo Maffei; tem extensão de 1.300 metros.

- Segmento 4 - Ciclovia unidirecional no sentido centro-bairro e ciclofaixa unidirecional no sentido bairro-centro, situadas uma de cada lado da Avenida Integração; tem extensão de 1.000 metros.

- Segmento 5 - Ciclovia bidirecional situada no canteiro central da Avenida Trabalhador Sãocarlense; tem extensão de 170 metros.

- Segmento 6 - Ciclovia bidirecional situada ao lado de um dos acostamentos da Rodovia Luiz Augusto de Oliveira; tem extensão de 1.350 metros.

- Segmento 7 - Ciclovia bidirecional situada no canteiro central da Avenida Comendador Alfredo Maffei; tem extensão de 1.700 metros.

Na Figura 4.3 é mostrada a localização desses sete segmentos cicloviários. 


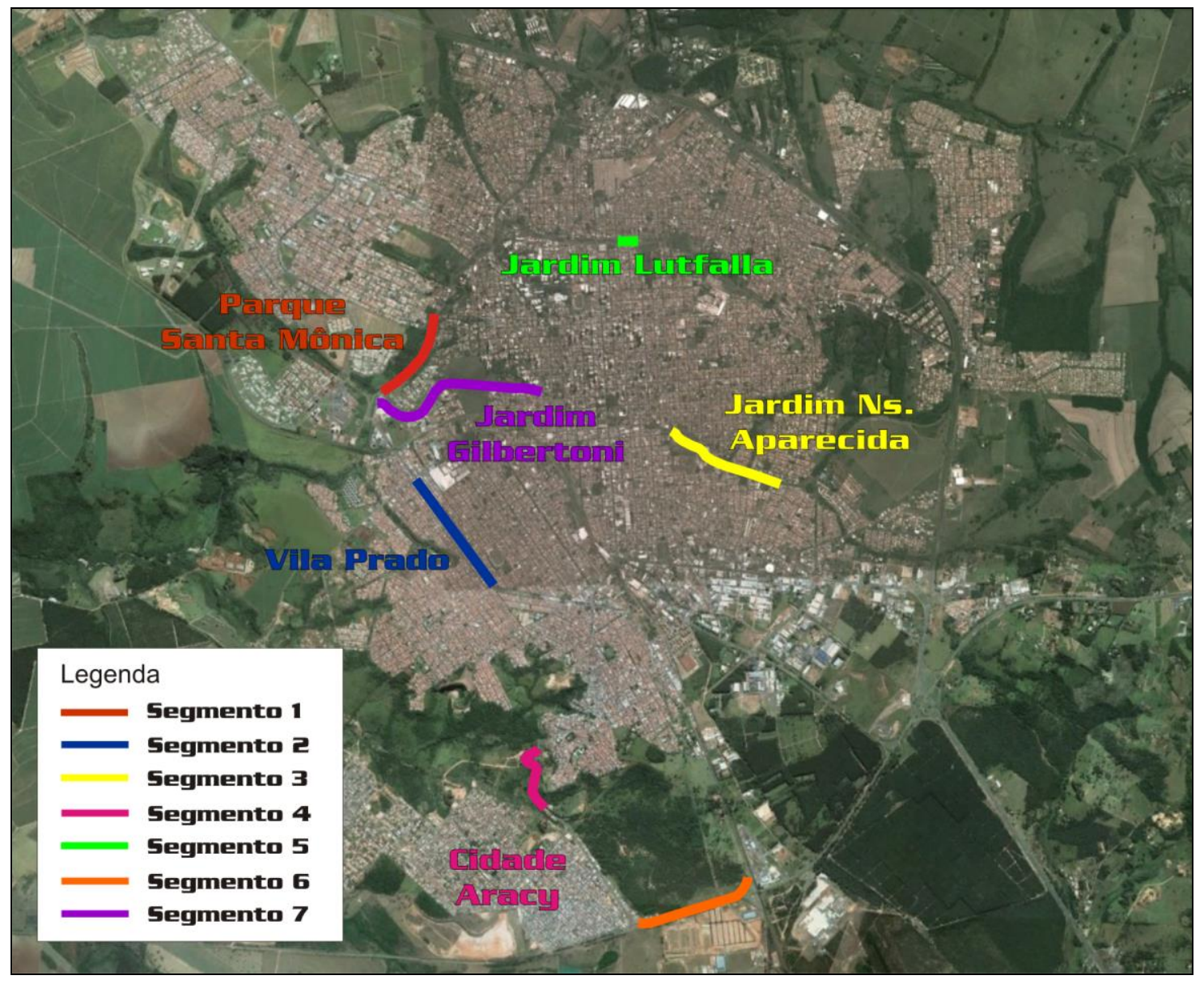

Figura 4.3 - Localização dos segmentos cicloviários de São Carlos.

\subsection{Caracterização e avaliação do segmento 1}

\section{Caracterização física e operacional}

O segmento 1 é constituído de ciclofaixa bidirecional situada em uma das pistas da Av. Francisco Pereira Lopes. Tem 2,65 metros de largura, 1.000 metros de extensão e perfil longitudinal plano.

Na Figura 4.4 é mostrado o trajeto do segmento 1. 


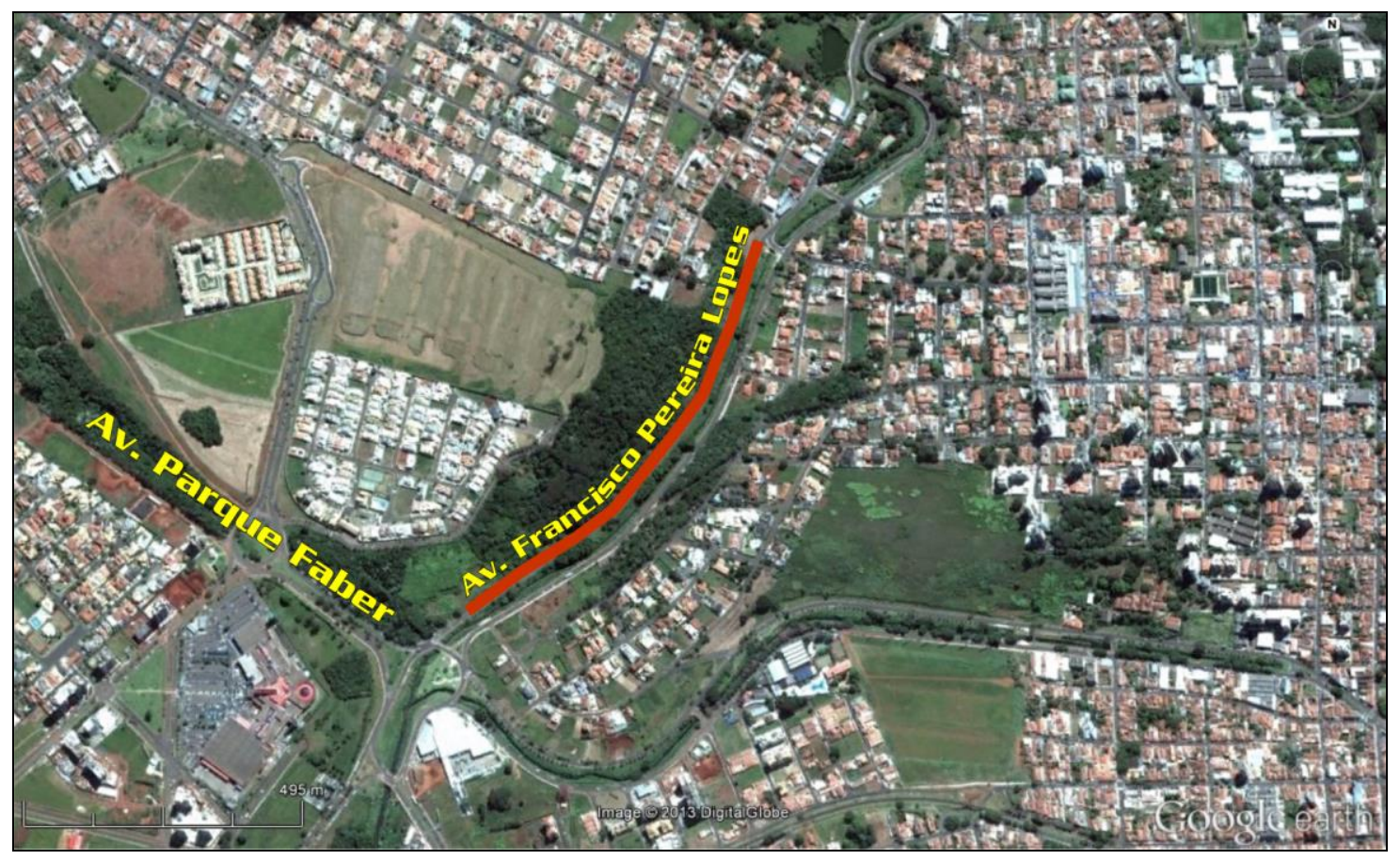

Figura 4.4 - Trajeto do segmento 1.

Na Figura 4.5 é mostrada a seção transversal do sistema viário no segmento 1.

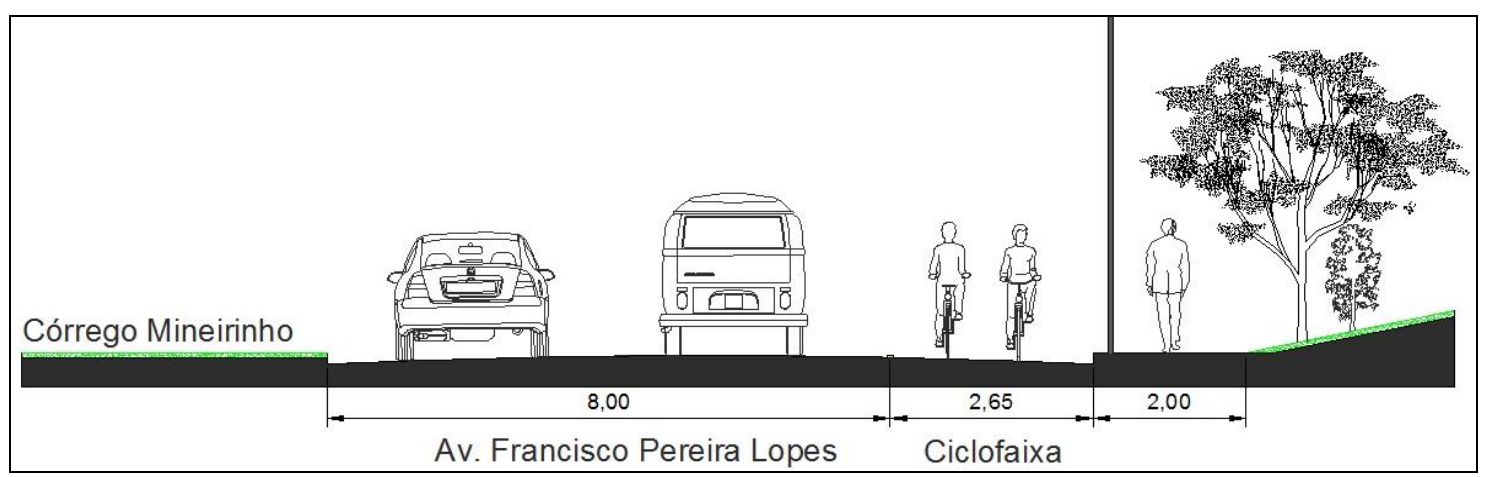

Figura 4.5 - Seção transversal do sistema viário no segmento.

Nas Figuras 4.6 a 4.9 são mostrados diferentes aspectos do segmento 1. 


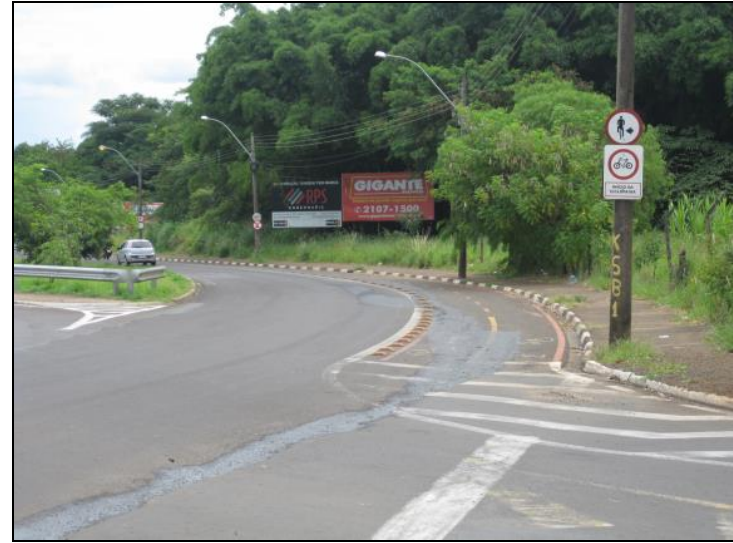

Figura 4.6 - Extremidade do segmento distante do Shopping Center.

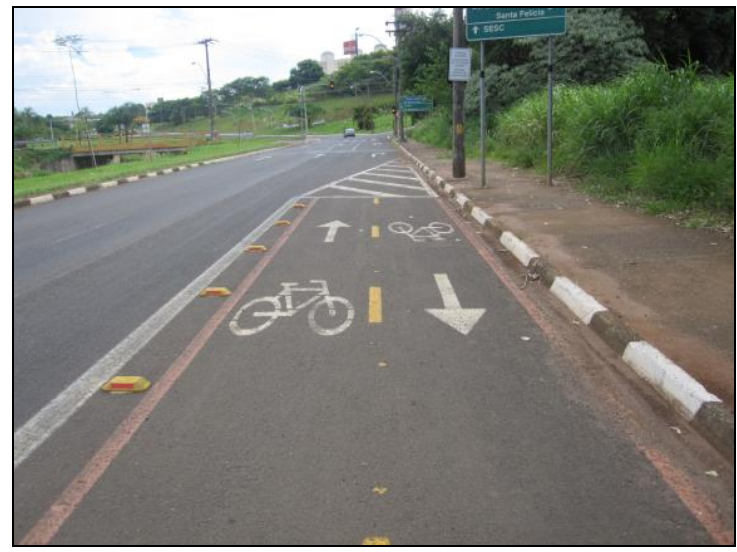

Figura 4.8 - Extremidade do segmento próxima do Shopping Center.

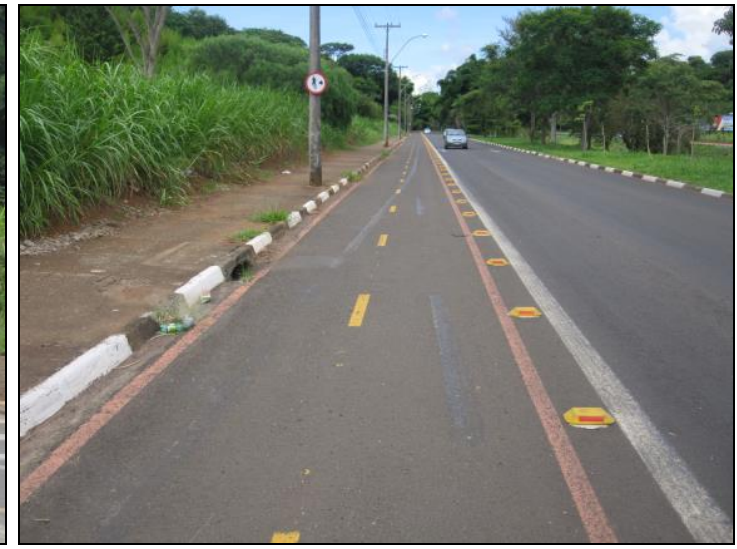

Figura 4.7 - Vista geral da ciclovia.

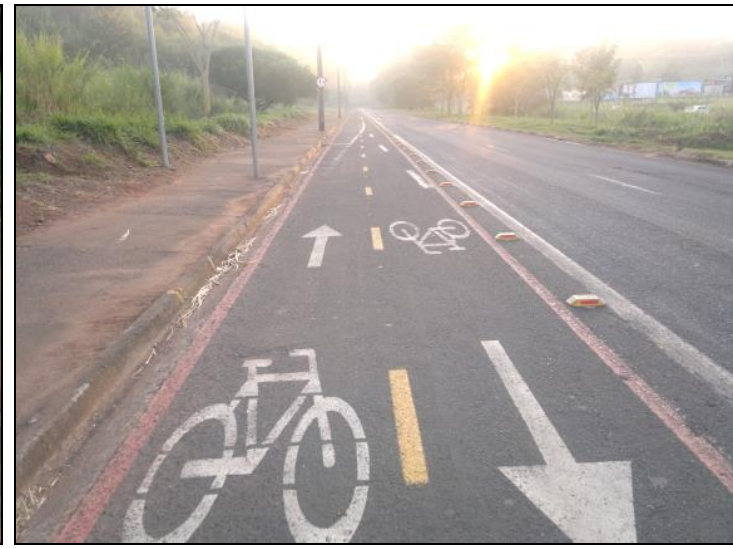

Figura 4.9 - Aspecto geral da sinalização horizontal.

A ciclofaixa é separada do fluxo normal por linha contínua vermelha e tachões espaçados. Também do lado da guia, a ciclofaixa é delimitada por linha contínua vermelha. Os fluxos opostos são separados por linha amarela.

A sinalização horizontal e vertical é adequada e se encontra em bom estado.

O estado geral de conservação é bom.

Como não há cruzamentos com outras vias, os ciclistas se deslocam sem necessidade de parar para dar passagem a outros veículos ou pedestres.

A implantação da ciclofaixa reduziu a largura da pista de 10,70 para 8,00 metros, diminuindo, assim, o número de faixas de tráfego de três para duas. $\mathrm{Na}$ 
extremidade onde existe semáforo, a ciclofaixa é interrompida antes para que a pista volte a ter três faixas de tráfego.

\section{Fluxo de bicicletas}

As contagens do fluxo do tráfego de bicicletas foram realizadas nos períodos de maior movimento: de manhã, das 06:30 às 09:00 h, no meio do dia, das 11:30 às 13:30, e à tarde, das 17:00 às 19:00 h. Na Tabela 4.2 estão relacionados os valores dos fluxos horários encontrados.

Tabela 4.2 - Valores do volume horário (bicicleta/hora).

\begin{tabular}{|c|c|c|c|c|c|c|c|c|}
\hline \multicolumn{3}{|c|}{ Na ciclovia } & \multicolumn{3}{|c|}{ Fora da ciclovia } & \multicolumn{3}{|c|}{ Total } \\
\hline Manhã & $\begin{array}{l}\text { Meio } \\
\text { do dia }\end{array}$ & Tarde & Manhã & $\begin{array}{l}\text { Meio } \\
\text { do dia }\end{array}$ & Tarde & Manhã & $\begin{array}{l}\text { Meio } \\
\text { do dia }\end{array}$ & Tarde \\
\hline 7,6 & 2,5 & 28,0 & 8,8 & 3,5 & 23,0 & 16,4 & 6,0 & 51,0 \\
\hline \multicolumn{3}{|c|}{ Média = 12,7 } & \multicolumn{3}{|c|}{ Média $=11,8$} & \multicolumn{3}{|c|}{ Média = 24,5 } \\
\hline
\end{tabular}

Os valores da Tabela 4.2 permitem inferir que:

- O fluxo de bicicletas no local é pequeno; em média, nos horários de maior movimento, uma bicicleta a cada 2,5 minutos.

- $51,8 \%$ utilizavam a ciclovia e $48,2 \%$ não utilizavam.

\section{$\underline{\text { Pesquisa com ciclistas }}$}

Dos dez ciclistas que utilizavam a ciclovia, oito (70\%) responderam que usavam a bicicleta para passear e/ou fazer exercícios e três (30\%) por outro motivo (trabalhar, estudar, fazer compras, encontrar com amigos, etc.).

Dos dez ciclistas que não utilizavam a ciclovia, três (30\%) responderam que usavam a bicicleta para passear e/ou fazer exercícios e sete (70\%) por outro motivo (trabalhar, estudar, fazer compras, encontrar com amigos, etc.). Todos $(100 \%)$ disseram que era melhor utilizar a direita da via da pista oposta onde se situa a ciclovia porque é perigoso e demorado entrar e sair da ciclofaixa que está na pista oposta, uma vez que tem que cruzar/ "cortar" fluxos veiculares.

\section{Pesquisa com moradores da vizinhança}


Dos dez moradores da vizinhança entrevistados, oito (80\%) responderam que não foi importante a Prefeitura ter implantado a ciclovia, uma vez que ela tem pouco uso, e que os recursos deveriam ter sido empregados em outros benefícios para a região.

Dois deles (20\%) responderam que foi importante, uma vez que ela constitui espaço para a prática de exercícios e de lazer.

\section{Avaliação do segmento}

Os seguintes pontos são relevantes no tocante ao segmento 1:

- Apesar de não constituir um investimento de grande valor, a implantação da ciclofaixa é questionável do ponto de vista socioeconômico uma vez que o tráfego de bicicletas no trecho do sistema viário onde ela se situa é muito pequeno.

- A implantação da ciclofaixa é questionável do ponto de vista político, pois a maioria dos moradores da vizinhança não aprova a obra.

- A visão da minoria dos moradores que aprovam a ciclofaixa é que ela constitui um espaço para a prática de exercícios e de lazer e não para deslocamentos por motivo de trabalho, estudo, compras, etc. - o que se comprova na prática, pois a maioria dos usuários utiliza a mesma para a prática de exercícios e de lazer.

- O projeto da ciclofaixa bidirecional em uma pista é questionável do ponto de vista técnico, pois praticamente todos os ciclistas que se deslocam no sentido de fluxo contrário ao da pista onde se localiza a ciclofaixa, por razões de segurança e praticidade, trafegam do lado direito da pista oposta. Isso leva a conclusão que o indicado teria sido implantar ciclofaixas unidirecionais do lado direito das duas pistas com sentidos contrários.

- O impacto no trânsito é pequeno, pois o volume de veículos no trecho em que a largura da via foi reduzida é pequeno. 
- Como a ciclovia é nova, as condições do pavimento, a sinalização e a conservação da mesma são bastante satisfatórias.

\subsection{Caracterização e avaliação do segmento 2}

\section{Caracterização física e operacional}

Consiste de ciclovia bidirecional, com largura de 2,65 metros, situada no canteiro central da Rua Henrique Gregori. Tem extensão de 1.125 metros, declividade máxima de $2 \%$ e piso de bloquete intertravado.

Na Figura 4.10 é mostrado o trajeto deste segmento.

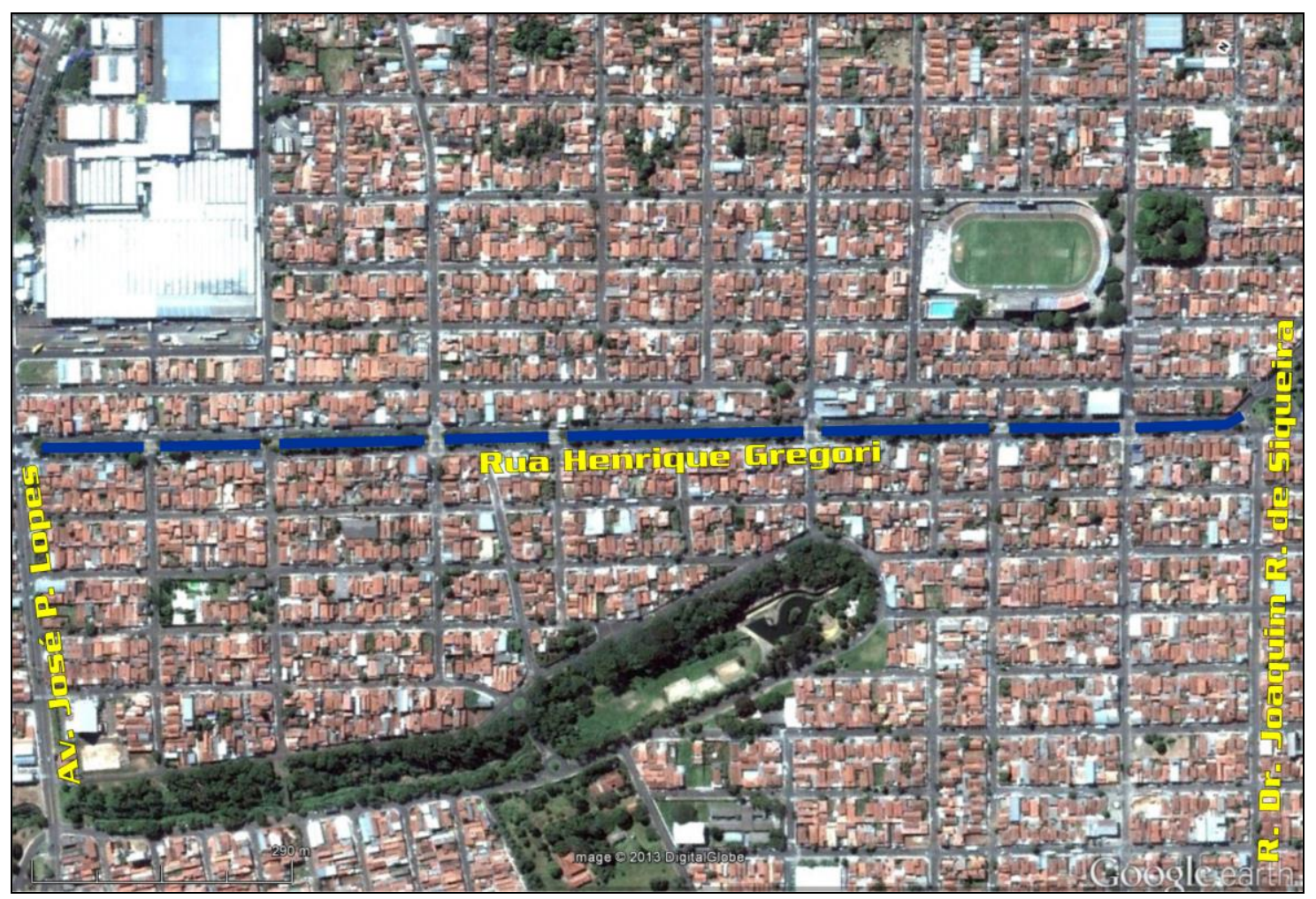

Figura 4.10 - Trajeto do segmento 2.

Na Figura 4.11 é mostrada a seção transversal do sistema viário no segmento. 


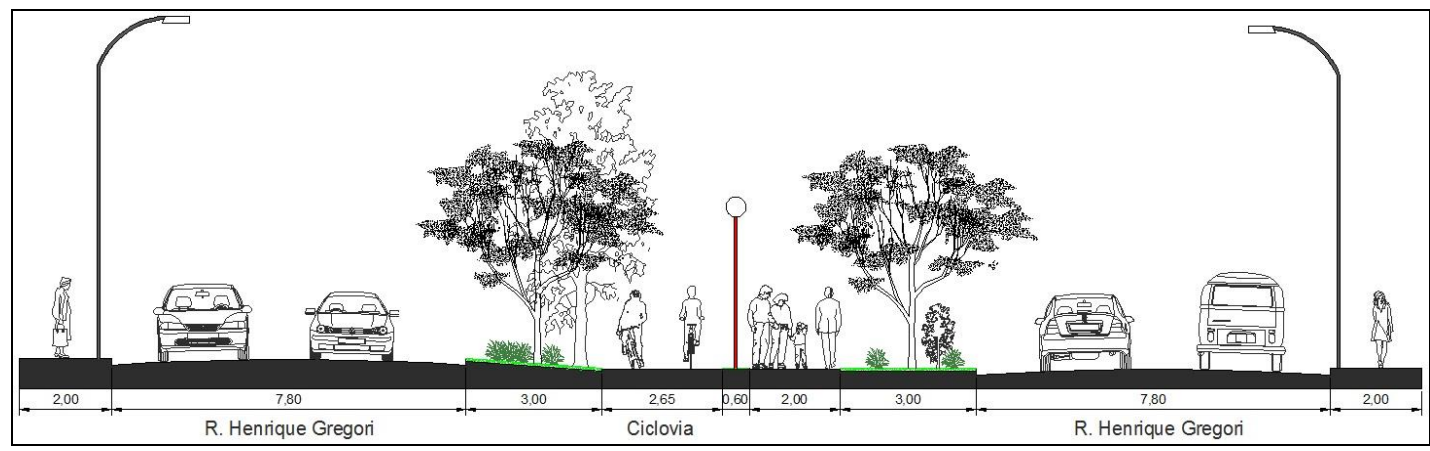

Figura 4.11 - Seção transversal do sistema viário no segmento.

Nas Figuras 4.12 a 4.14 são mostradas diferentes aspectos deste segmento.

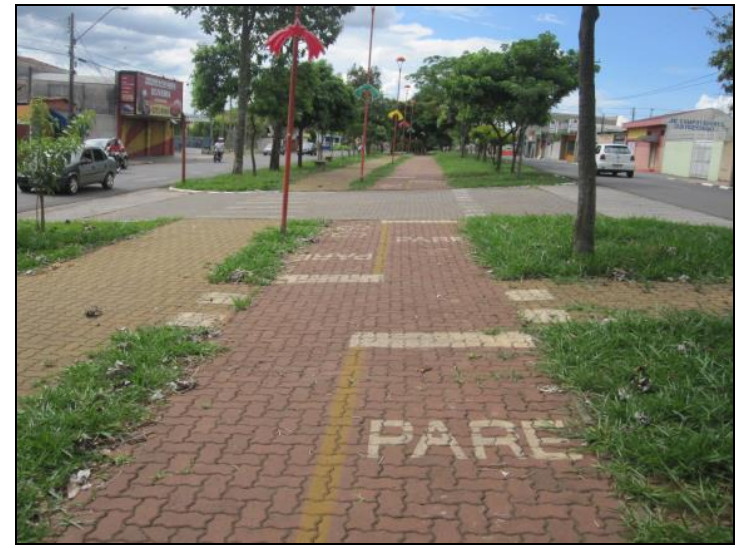

Figura 4.12 - Sinalização da ciclovia em cruzamento com via transversal.

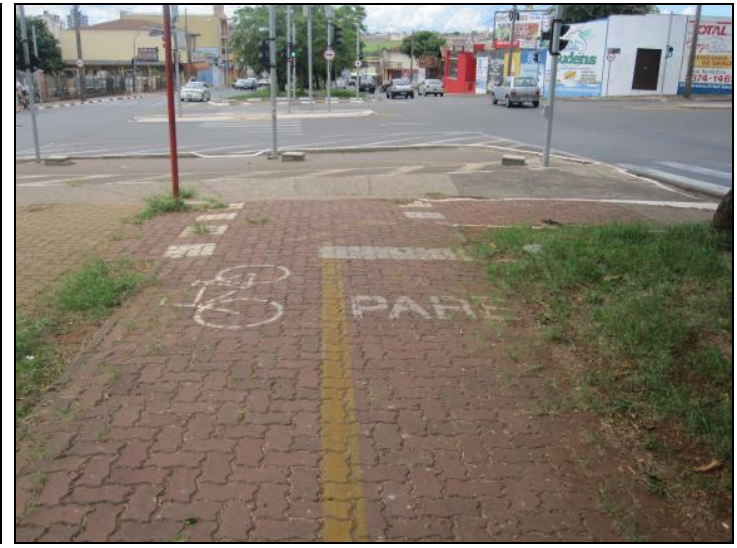

Figura 4.13 - Vista da sinalização da ciclovia em interseção com rotatória.

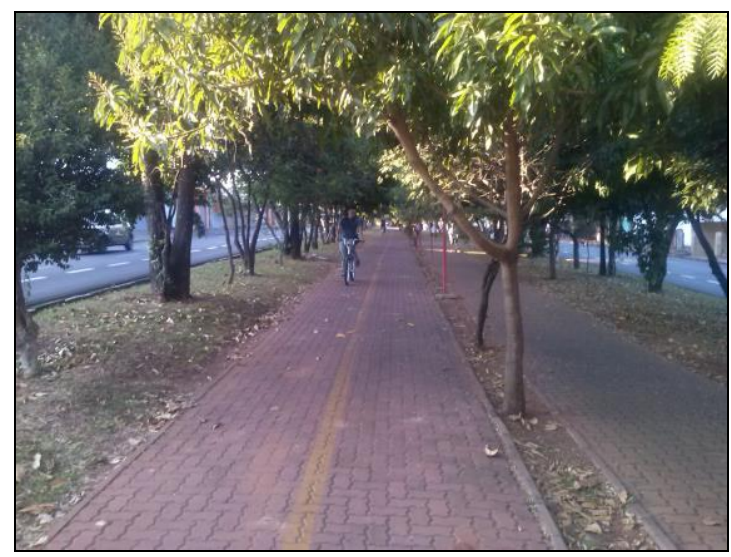

Figura 4.14 - Vista da sinalização da ciclovia. 
A ciclovia está inserida num amplo espaço verde com muitas árvores. 0 espaço é convidativo à circulação de pedestres e ciclistas, e muito utilizado para prática de caminhada e passeio de bicicleta nos finais de tarde.

O confinamento é feito de guias de menor tamanho utilizadas em canteiros de praças e jardins. A separação das faixas do tráfego de bicicletas é feito com linha amarela.

As sinalizações vertical e horizontal são adequadas e se encontram em bom estado.

O estado geral de conservação é bom.

Os ciclistas devem parar em todos os cruzamentos com vias transversais e com faixas de pedestres.

\section{Fluxo de bicicletas}

As contagens do fluxo do tráfego de bicicletas foram realizadas nos períodos de maior movimento: de manhã, das 06:30 às 09:00 h, no meio do dia, das 11:30 às 13:30, e à tarde, das 17:00 às 19:00 h. Na Tabela 4.3 estão relacionados os valores dos fluxos horários encontrados.

Tabela 4.3 - Valores do volume horário (bicicleta/hora).

\begin{tabular}{|c|c|c|c|c|c|c|c|c|}
\hline \multicolumn{3}{|c|}{ Na ciclovia } & \multicolumn{3}{|c|}{ Fora da ciclovia } & \multicolumn{3}{|c|}{ Total } \\
\hline Manhã & $\begin{array}{l}\text { Meio } \\
\text { do dia }\end{array}$ & Tarde & Manhã & $\begin{array}{l}\text { Meio } \\
\text { do dia }\end{array}$ & Tarde & Manhã & $\begin{array}{l}\text { Meio } \\
\text { do dia }\end{array}$ & Tarde \\
\hline 8,0 & 13,5 & 48,0 & 11,2 & 9,0 & 26,5 & 19,2 & 22,5 & 74,5 \\
\hline \multicolumn{3}{|c|}{ Média = 23,2 } & \multicolumn{3}{|c|}{ Média = 15,6 } & \multicolumn{3}{|c|}{ Média $=38,8$} \\
\hline
\end{tabular}

Os valores da Tabela 4.3 permitem inferir que:

- O fluxo de bicicletas é pequeno; em média, nos horários de maior movimento, uma bicicleta a cada 1,5 minutos.

- $59,8 \%$ utilizavam a ciclovia e $40,2 \%$ não utilizavam.

\section{Pesquisa com ciclistas}


Dos dez ciclistas que utilizavam a ciclovia, oito (80\%) responderam que usavam a bicicleta para passear e/ou fazer exercícios e dois (20\%) por outro motivo (trabalhar, estudar, fazer compras, encontrar com amigos, etc.).

Dos dez ciclistas que não utilizavam a ciclovia, um (10\%) respondeu que usava a bicicleta para passear e fazer exercícios e nove (90\%) por outro motivo (trabalhar, estudar, fazer compras, encontrar com amigos, etc.). Todos (100\%) disseram que era melhor utilizar a direita das vias normais porque não tinham que parar nos cruzamentos para dar a preferência a outros veículos e pedestres e que era perigoso e demorado entrar e sair da ciclovia, uma vez que tinham que cruzar/ "cortar" fluxos veiculares.

\section{Pesquisa com moradores da vizinhança}

Todos os dez moradores da vizinhança (100\%) responderam que foi importante a Prefeitura ter implantado a ciclovia, pois ela, associada à pista de caminhada que foi construída ao lado, constitui um valioso espaço para a prática de exercícios e de lazer.

\section{Avaliação do segmento}

Os seguintes pontos são relevantes no tocante ao segmento 2:

- A implantação da ciclovia é justificável do ponto de vista socioeconômico, uma vez que ela constitui um valioso espaço para a prática de exercícios e de lazer e está situada em uma área que proporciona total condição de segurança para os usuários.

- A implantação da ciclovia tem amplo apoio dos moradores da vizinhança, o que the confere viabilidade política.

- A visão dos moradores é que ciclovia constitui um espaço para a prática de exercícios e de lazer e não para deslocamentos por motivo de trabalho, estudo, compras, etc. - o que se comprova na prática, pois a maioria dos usuários utiliza a mesma para a prática de exercícios e de lazer. 
- O projeto de ciclovia bidirecional no canteiro central não atende às aspirações dos usuários que se deslocam por motivo de trabalho, estudo, compras, etc., pois esses, na sua maioria, por razões de segurança e praticidade, optam por trafegar do lado direito das pistas do tráfego motorizado. Para eles o indicado seria implantar ciclofaixas unidirecionais do lado direito das duas pistas com sentidos contrários.

- Não há impacto no trânsito, pois a ciclovia se situa no canteiro central de uma via e a preferência nos cruzamentos é dos veículos motorizados e dos pedestres.

- As condições do pavimento, a sinalização e a conservação da ciclovia são satisfatórias.

\subsection{Caracterização e avaliação do segmento 3}

\section{Caracterização física e operacional}

É constituído de ciclofaixa bidirecional com 2,65 metros de largura, 1.300 metros de extensão e declividade máxima de $2 \%$, estando localizado em uma das pistas da Avenida Comendador Alfredo Maffei.

A separação do tráfego motorizado é feita com tachões e linha vermelha contínua. Também do lado da guia a ciclofaixa é delimitada por linha contínua vermelha. Os fluxos são separados por linha amarela.

A implantação da ciclofaixa reduziu a largura de uma das pistas de 9,65 para 7,00 metros, diminuindo, assim, o número de faixas de tráfego de três para duas.

O trecho possui adequada sinalização vertical e horizontal e se encontra em bom estado.

O estado geral de conservação é bom, exceto pela existência de bocas de lobo sem grades em alguns pontos da mesma. 
Os ciclistas devem parar em todos os cruzamentos com vias transversais.

O problema desta ciclofaixa é o tráfego de bicicletas no contra fluxo, que aumenta significativamente o risco de acidentes nos cruzamentos, pois as bicicletas que estão se movimentando na "contramão" em relação ao fluxo de veículos motorizados podem não ser vistas pelos motoristas que cruzam a ciclofaixa, habituados que estão a olhar apenas para o lado do fluxo de veículos motorizados.

Na Figura 4.15 é mostrado o trajeto deste segmento.

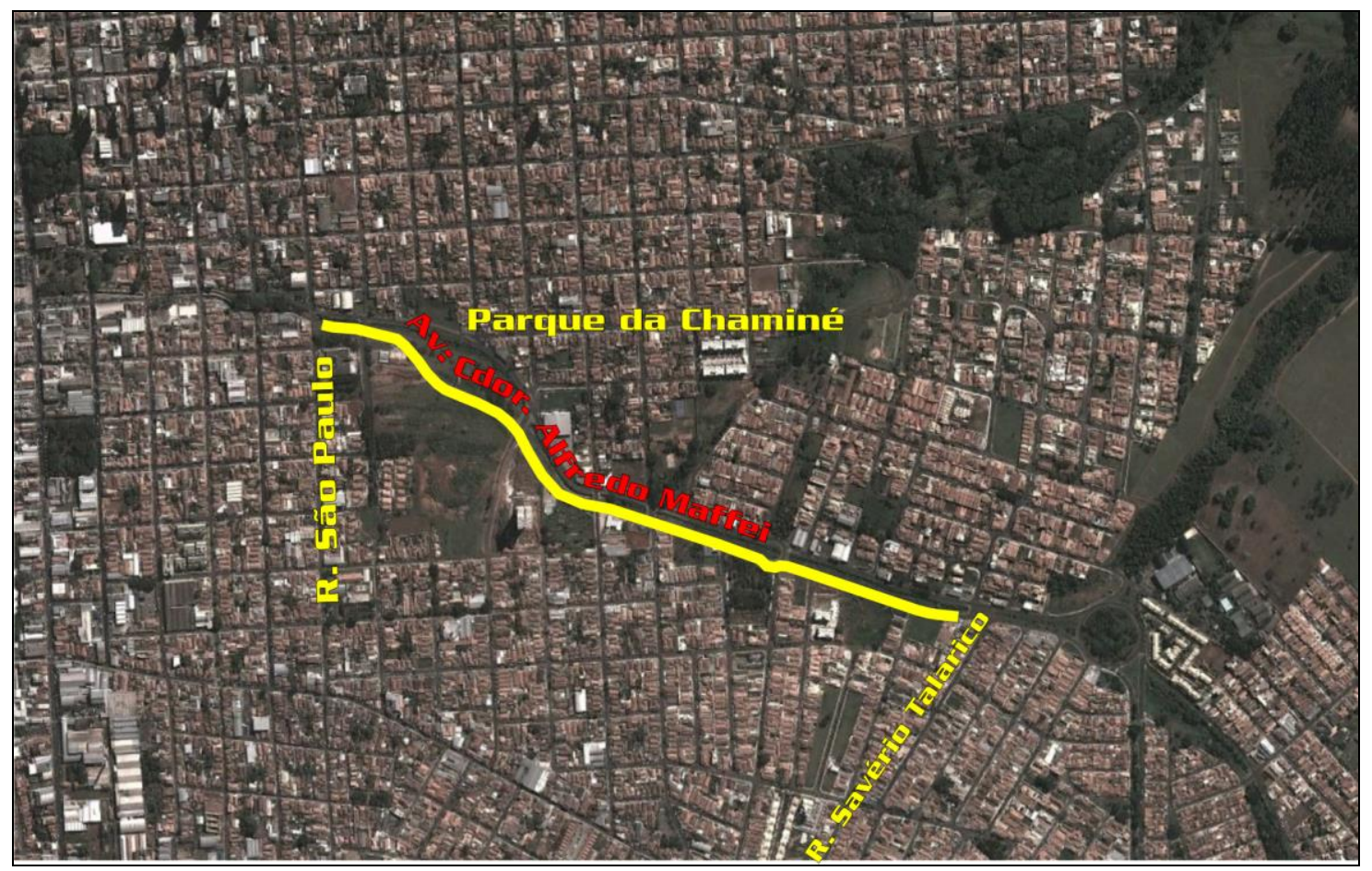

Figura 4.15 - Trajeto do segmento 3.

Nas Figuras 4.16 a 4.21 são mostradas diferentes vistas do segmento cicloviário. 


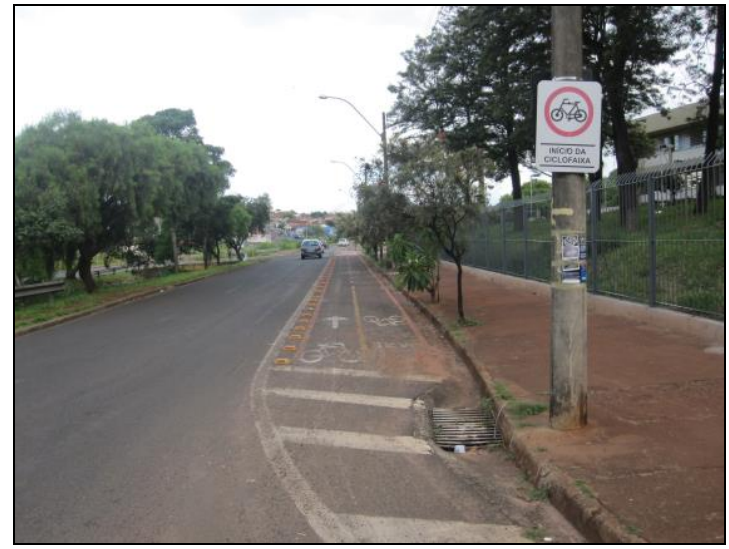

Figura 4.16 - Vista da sinalização da ciclovia.

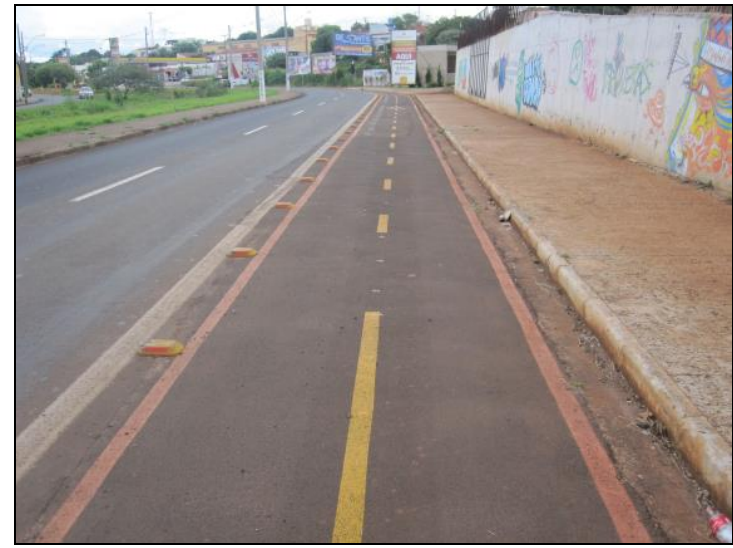

Figura 4.18 - Vista da sinalização da ciclovia.

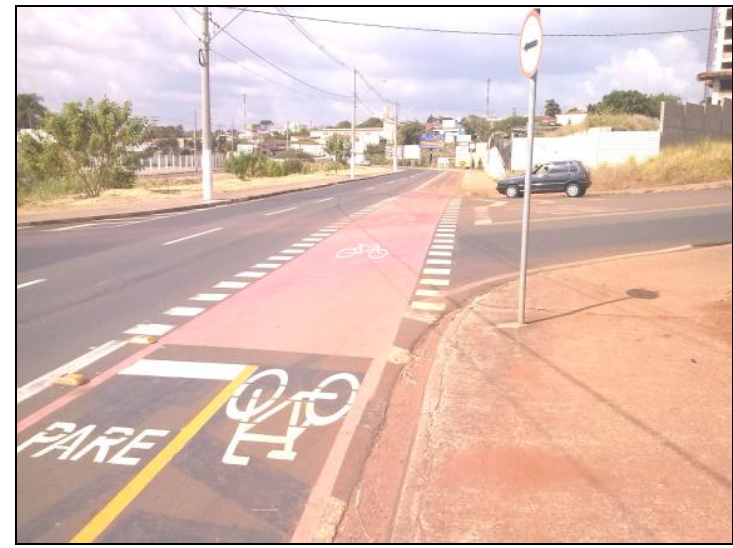

Figura 4.20 - Vista da sinalização da ciclovia.

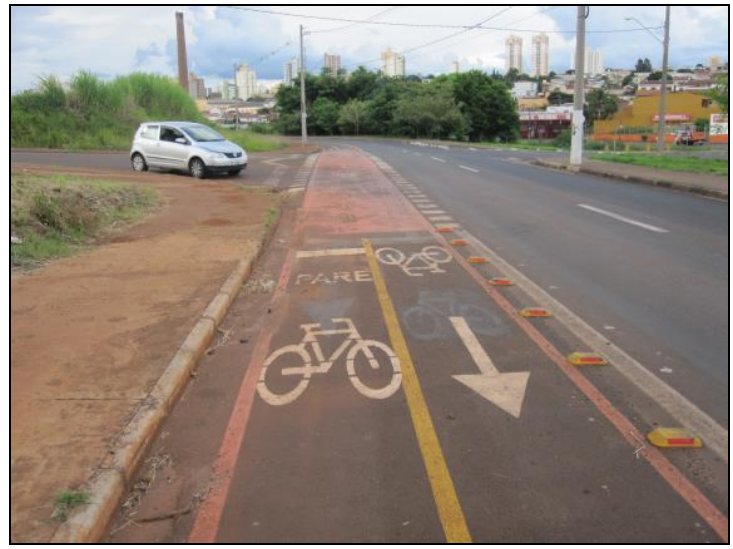

Figura 4.17 - Vista da sinalização da ciclovia.

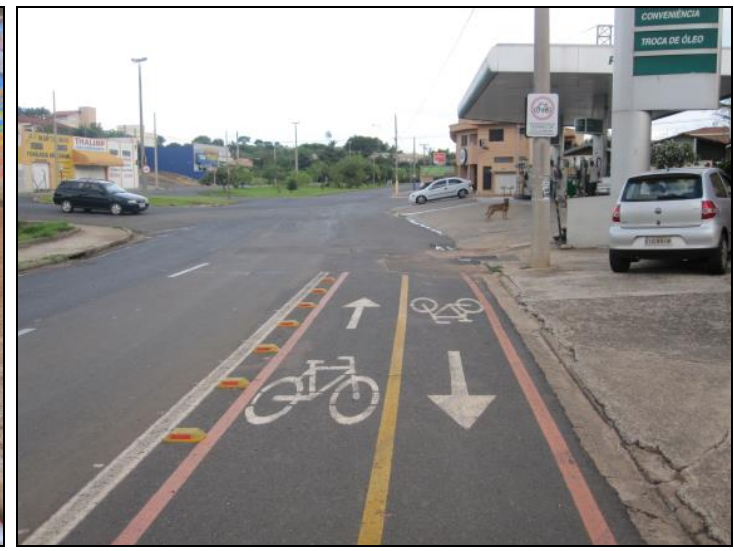

Figura 4.19 - Vista da sinalização da ciclovia.

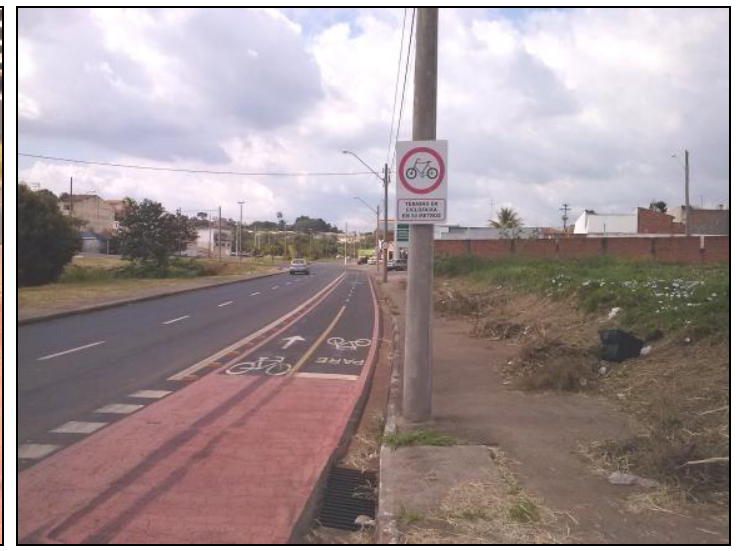

Figura 4.21 - Vista da sinalização da ciclovia.

\section{Fluxo de bicicletas}


As contagens do fluxo do tráfego de bicicletas foram realizadas nos períodos de maior movimento: de manhã, das 06:30 às 09:00 h, no meio do dia, das 11:30 às 13:30, e à tarde, das 17:00 às 19:00 h. Na Tabela 4.4 estão relacionados os valores dos fluxos horários encontrados.

Tabela 4.4 - Valores do volume horário (bicicleta/hora).

\begin{tabular}{ccccccccc}
\hline \multicolumn{3}{c}{ Na ciclovia } & \multicolumn{4}{c}{ Fora da ciclovia } & \multicolumn{3}{c}{ Total } \\
\hline Manhã & $\begin{array}{c}\text { Meio } \\
\text { do dia }\end{array}$ & Tarde & Manhã $\begin{array}{c}\text { Meio } \\
\text { do dia }\end{array}$ & Tarde & Manhã & $\begin{array}{c}\text { Meio } \\
\text { do dia }\end{array}$ & Tarde \\
\hline 4,0 & 5,5 & 10,5 & 1,6 & 1,5 & 4,5 & 5,6 & 7,0 & 15,0 \\
& $\begin{array}{c}1,5 \\
\text { Média }=6,7\end{array}$ & \multicolumn{2}{c}{ Média $=2,5$} & & Média $=9,2$ & \\
\hline
\end{tabular}

Os valores da Tabela 4.4 permitem inferir que:

- O fluxo de bicicletas no local é muito pequeno; em média, nos horários de maior movimento, uma bicicleta a cada 6,5 minutos.

- $59,8 \%$ utilizam a ciclovia e $40,2 \%$ não utilizam.

\section{Pesquisa com ciclistas}

Dos dez ciclistas que utilizavam a ciclovia, seis $(60 \%)$ responderam que usavam a bicicleta para passear e/ou fazer exercícios e quatro (40\%) por outro motivo (trabalhar, estudar, fazer compras, encontrar com amigos, etc.).

Dos dez ciclistas que não utilizavam a ciclovia, cinco (50\%) responderam que usavam a bicicleta para passear e/ou fazer exercícios e cinco (50\%) por outro motivo (trabalhar, estudar, fazer compras, encontrar com amigos, etc.). Todos $(100 \%)$ disseram que era melhor utilizar a direita da via da pista oposta porque não tinham que parar nos cruzamentos para dar a preferência a outros veículos e pedestres e que era perigoso e demorado entrar e sair da ciclovia, uma vez que tinham que cruzar/ "cortar" fluxos veiculares.

\section{Pesquisa com moradores da vizinhança}

Quatro dos dez moradores entrevistados, portanto $40 \%$, responderam que foi importante a Prefeitura ter implantado a ciclofaixa, sobretudo para ser utilizada como espaço para a prática de exercícios e de lazer. 
Seis $(60 \%)$ disseram que não foi importante e que os recursos deveriam ter sido empregados em outros benefícios para a região.

\section{Avaliação do segmento}

Os seguintes pontos são relevantes no tocante ao segmento 3:

- Apesar de não constituir um investimento de grande monta, a implantação da ciclofaixa é questionável do ponto de vista socioeconômico uma vez que o tráfego de bicicletas no trecho do sistema viário onde ela se situa é muito pequeno.

- A implantação da ciclofaixa é questionável do ponto de vista político, pois a maioria dos moradores da vizinhança não aprova a obra.

- A visão da minoria dos moradores que aprovam a ciclofaixa é que ela constitui um espaço para a prática de exercícios e de lazer e não para deslocamentos por motivo de trabalho, estudo, compras, etc. - o que se comprova na prática, pois a maioria dos usuários utiliza a mesma para a prática de exercícios e de lazer.

- O projeto da ciclofaixa bidirecional em uma pista é questionável do ponto de vista técnico, pois praticamente todos os ciclistas que se deslocam no sentido de fluxo contrário ao da pista onde se localiza a ciclofaixa, por razões de segurança e praticidade, trafegam do lado direito da pista oposta. Isso leva a conclusão que o indicado teria sido implantar ciclofaixas unidirecionais do lado direito das duas pistas com sentidos contrários.

- O impacto no trânsito é pequeno, pois o volume de veículos no trecho em que a o número de faixas foi reduzido de três para dois não é alto.

- Como a ciclofaixa é nova, as condições do pavimento, a sinalização e a conservação da mesma são bastante satisfatórias. 


\subsection{Caracterização e avaliação do segmento 4}

\section{Caracterização física e operacional}

Trata-se de ciclovia unidirecional no sentido centro-bairro e ciclofaixa unidirecional no sentido bairro-centro, situadas uma de cada lado da Avenida Integração; tem extensão de 1.000 metros e declividade muito alta (em torno de $8 \%$ ) na sua maior parte.

A ciclovia, com revestimento asfáltico, tem 2,0 metros de largura e é confinada na sua maior parte por muretas de concreto. A ciclofaixa, também com 2,0 metros de largura, é separada do fluxo normal por linha contínua de cor vermelha e tachas espaçadas.

A implantação da ciclovia e da ciclofaixa reduziu a largura da pista de 12,0 para 8,0 metros, diminuindo, assim, o número de faixas de tráfego por sentido de duas para uma. O impacto no trânsito foi grande, isso impede a ultrapassagem de veículos lentos, aumentando, assim, o tempo de viagem, sobretudo no sentido de aclive. No entanto, como o fluxo de veículos no trecho não é grande, isso não aparece com tanta ênfase.

A sinalização vertical é deficiente e as placas existentes se encontram em processo de deterioração.

A sinalização horizontal é adequada, mas se encontra em mal estado.

O estado geral de conservação é insatisfatório, pois há problemas na sinalização e defeitos no pavimento.

Como não há cruzamentos com outras vias, os ciclistas se deslocam sem necessidade de parar para dar passagem a outros veículos ou pedestres.

Na Figura 4.22 é mostrado o trajeto deste segmento. 


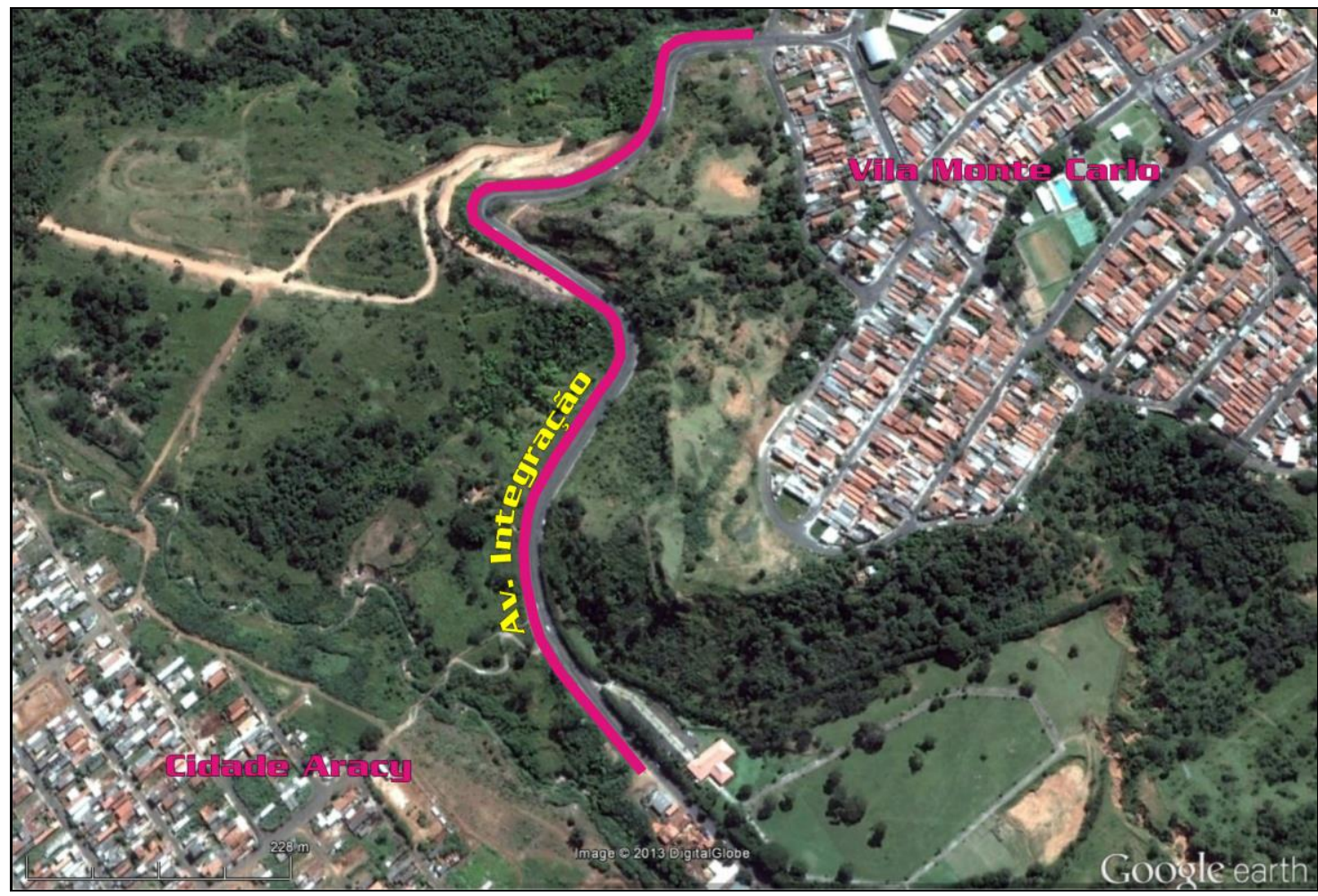

Figura 4.22 - Trajeto do segmento 4.

Nas Figuras 4.23 a 4.28 são mostrados diferentes aspectos deste segmento.

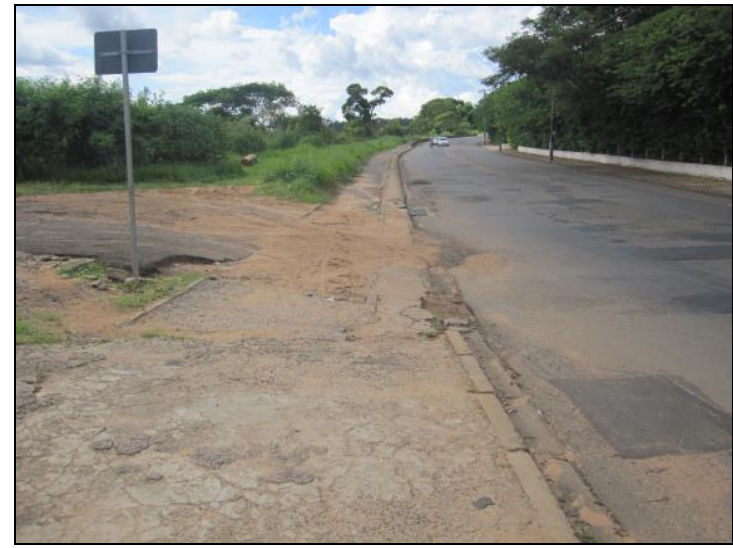

Figura 4.23 - Fim da ciclovia no Bairro Cidade Aracy.

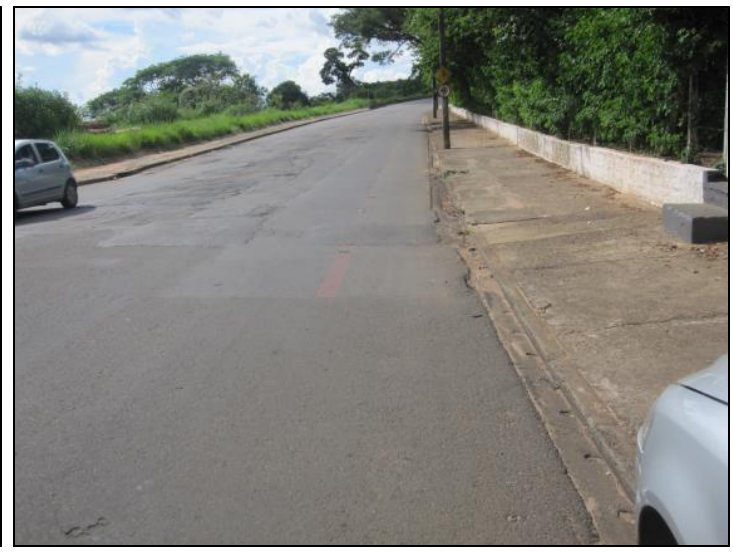

Figura 4.24 - Início da ciclofaixa no Bairro Cidade Aracy. 


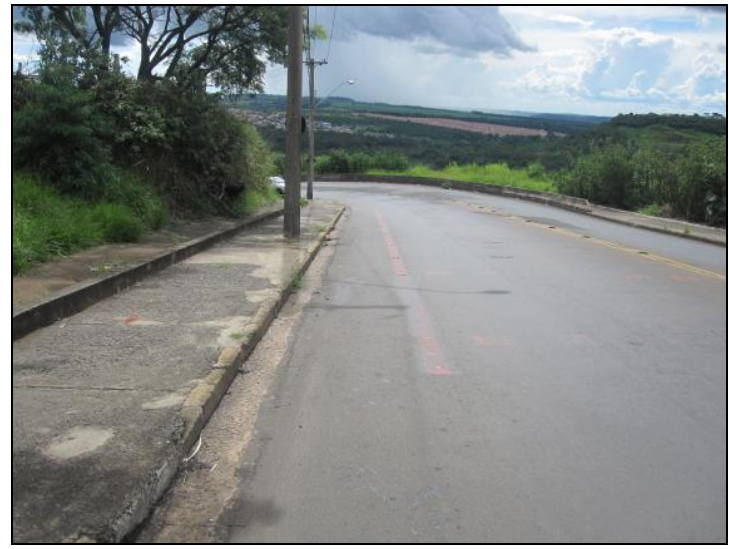

Figura 4.25 - Fim da ciclofaixa no Bairro Monte Carlo.

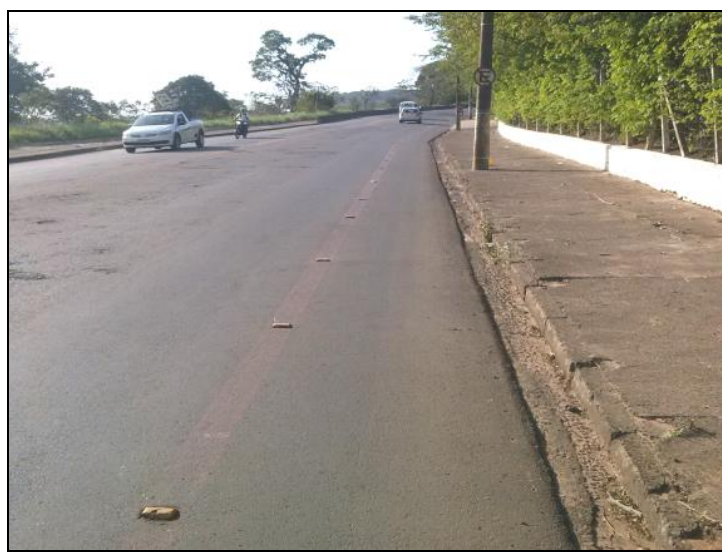

Figura 4.27 - Aspecto geral da ciclofaixa.

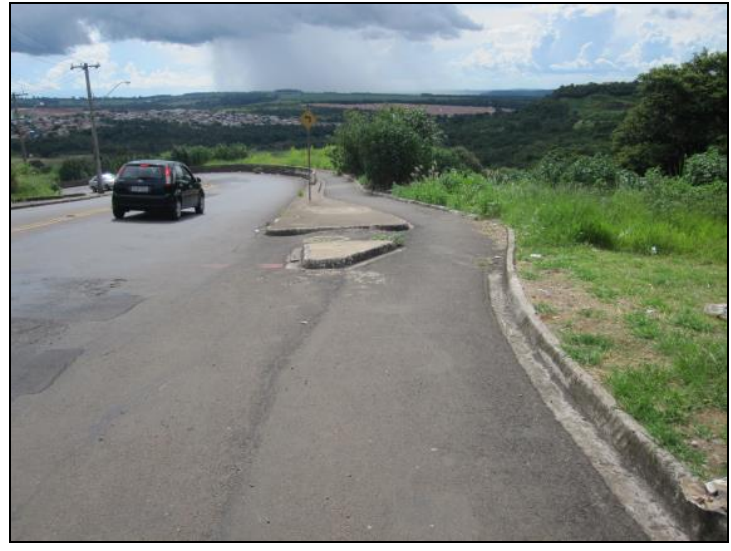

Figura 4.26 - Início da ciclovia no Bairro Monte Carlo.

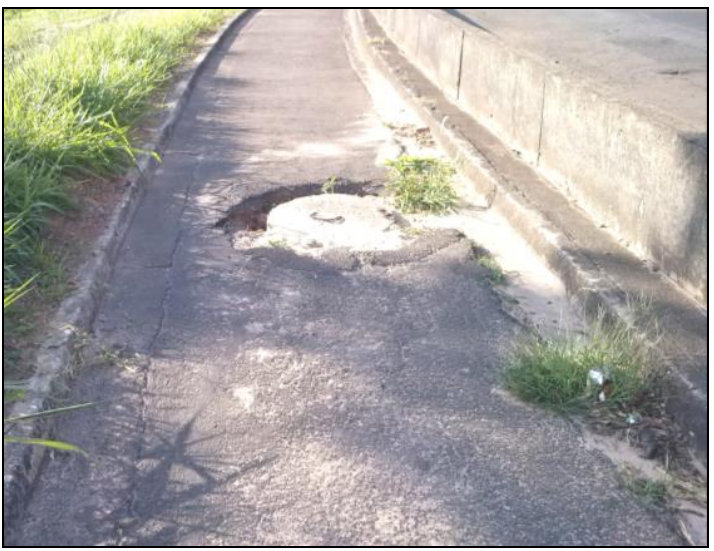

Figura 4.28 - Defeito no pavimento da ciclovia.

\section{Fluxo de bicicletas}

As contagens do fluxo do tráfego de bicicletas foram realizadas nos períodos de maior movimento: de manhã, das 06:30 às 09:00 h, no meio do dia, das 11:30 às 13:30, e à tarde, das 17:00 às 19:00 h. Na Tabela 4.5 estão relacionados os valores dos fluxos horários encontrados.

Tabela 4.5 - Valores do volume horário (bicicleta/hora).

\begin{tabular}{ccccccccc}
\hline \multicolumn{2}{c}{ Na ciclovia/ciclofaixa } & \multicolumn{3}{c}{$\begin{array}{c}\text { Fora da } \\
\text { ciclovia/ciclofaixa }\end{array}$} & \multicolumn{3}{c}{ Total } \\
\hline Manhã & $\begin{array}{c}\text { Meio } \\
\text { do dia }\end{array}$ & Tarde & Manhã $\begin{array}{c}\text { Meio } \\
\text { do dia }\end{array}$ & Tarde & Manhã & $\begin{array}{c}\text { Meio } \\
\text { do dia }\end{array}$ & Tarde \\
\hline 1,2 & $\begin{array}{c}2,0 \\
\text { Média }=3,1\end{array}$ & 6,0 & 0,8 & $\begin{array}{c}4,5 \\
\text { Média }=6,8\end{array}$ & 15,0 & 2,0 & $\begin{array}{c}6,5 \\
\text { Média }=9,9\end{array}$ & 21,0 \\
\hline
\end{tabular}


Os valores da Tabela 4.5 permitem inferir que:

- O fluxo de bicicletas no local é muito pequeno; em média, nos horários de maior movimento, uma bicicleta a cada 6,1 minutos.

- $68,7 \%$ utilizavam a ciclovia/ciclofaixa e 31,3\% não utilizavam.

\section{Pesquisa com ciclistas}

Todos os dez ciclistas que utilizavam a ciclovia (100\%) responderam que usavam a bicicleta para trabalhar, estudar, fazer compras, etc.).

Todos os dez ciclistas que não utilizavam a ciclovia (100\%) responderam que usavam a bicicleta para trabalhar, estudar, fazer compras, etc.). Todos (100\%) disseram que era melhor utilizar a via normal porque a piso da ciclovia estava muito ruim.

Nenhum dos dez ciclistas entrevistados pedalavam na ciclofaixa, sendo que 2 (20\%) empurravam a bicicleta na ciclofaixa e 8 (80\%) na calçada. Todos disseram que era impossível pedalar em razão da rampa ser muito íngreme. Os oito (80\%) que usavam a calçada disseram que era mais seguro e cômodo empurrar a bicicleta na calçada do que na ciclofaixa. Todos responderam que usavam a bicicleta para trabalhar, estudar, fazer compras, etc.

\section{Pesquisa com moradores da vizinhança}

Dos dez moradores da vizinhança entrevistados, seis (60\%) responderam que não foi importante a Prefeitura ter implantado a ciclovia, uma vez que ela tem pouco uso, e que os recursos deveriam ter sido gastos em outros benefícios para a região. Dois deles (20\%) assinalaram que a implantação da ciclovia e da ciclofaixa reduziu o número de faixas de tráfego por sentido de duas para uma. Quatro moradores (40\%) responderam que foi importante, porém disseram que é necessário fazer melhorias na mesma.

Nove dos dez entrevistados (90\%) disseram que a ciclofaixa não deveria ter sido implantada pelo fato da maior parte dela estar em rampa acentuada e ser impossível pedalar na mesma (a bicicleta tem que ser empurrada). 


\section{Avaliação do segmento}

Os seguintes pontos são relevantes no tocante ao segmento 5:

- A implantação da ciclovia e da ciclofaixa é questionável do ponto de vista socioeconômico, uma vez que o tráfego de bicicletas no trecho do sistema viário onde ela se situa é muito pequeno.

- A implantação da ciclovia é questionável do ponto de vista político, pois a maioria dos moradores da vizinhança (60\%) não aprova a obra. Com relação à ciclofaixa, a situação é muito pior, 90\% não aprovam a mesma.

- A ciclovia somente é utilizada para deslocamentos por motivo de motivo de trabalho, estudo, compras, etc., pois constitui um segmento de ciclovia situado em área não urbanizada.

- O projeto da ciclovia/ciclofaixa é questionável do ponto de vista técnico, pois está situado em local com declividade elevada, o que inibe fortemente o uso e obriga os usuários a empurrar a bicicleta na rampa.

- O impacto no trânsito foi grande, pois a implantação da ciclovia e da ciclofaixa reduziu o número de faixas de tráfego por sentido de duas para uma.

- As condições do pavimento, a sinalização e a conservação da ciclovia não são satisfatórias.

\subsection{Caracterização e avaliação do segmento 5}

\section{Caracterização física e operacional}

Consiste de ciclovia bidirecional situada no canteiro central da Avenida Trabalhador Sãocarlense, tem extensão de 170 metros e perfil longitudinal plano.

É conformada com linhas contínuas de cor vermelha e faixas por sentido separadas mediante linha amarela em um trecho e canteiro com grama e árvores no outro. A largura das faixas unidirecionais é de 1,40 metros. 
O piso de asfalto na sua maior parte com um pequeno trecho em concreto numa das extremidades.

O trecho possui adequada sinalização vertical e horizontal e em bom estado.

O estado geral de conservação é bom.

Os ciclistas devem parar em todos os cruzamentos com vias transversais.

Na Figura 4.29 é mostrado o trajeto deste segmento.

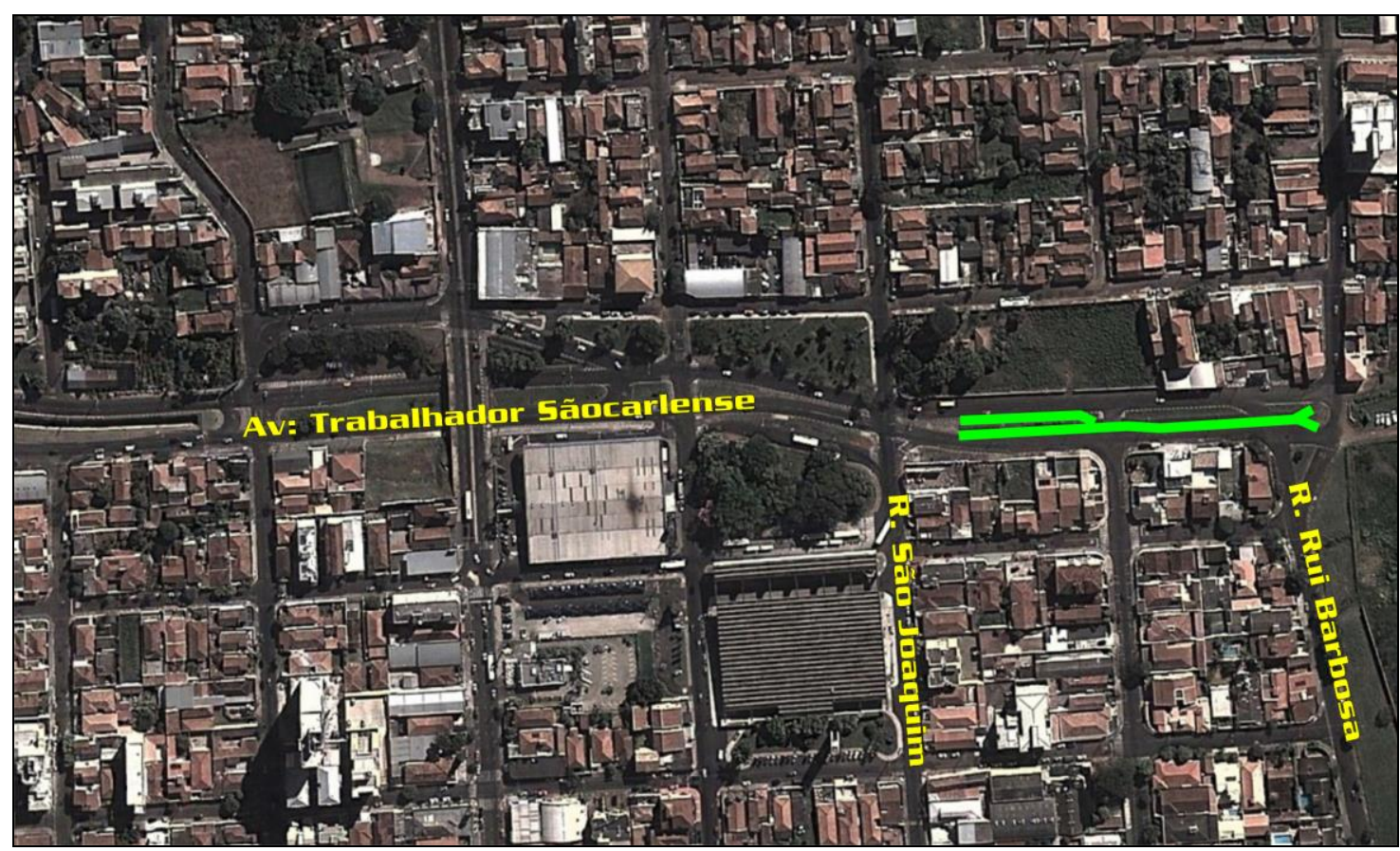

Figura 4.29 - Trajeto do segmento 5.

Nas Figuras 4.30 a 4.33 são mostrados diferentes aspectos deste segmento.

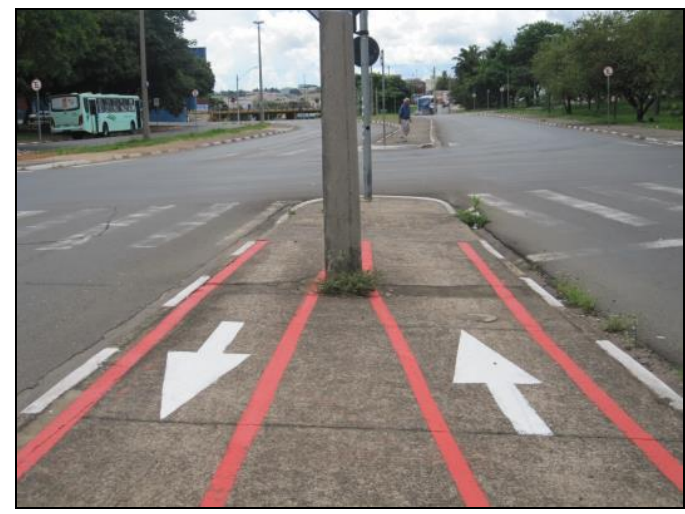

Figura 4.30 - Extremidade da ciclovia próxima da Estação Rodoviária.

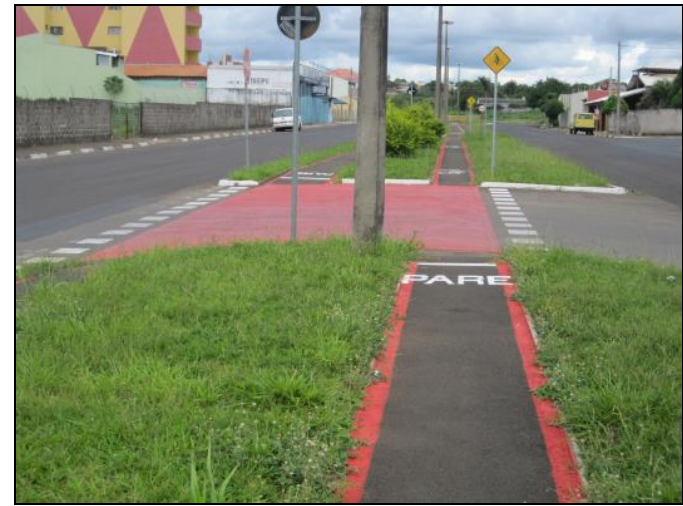

Figura 4.31 - Trecho intermediário com ida e volta separados. 


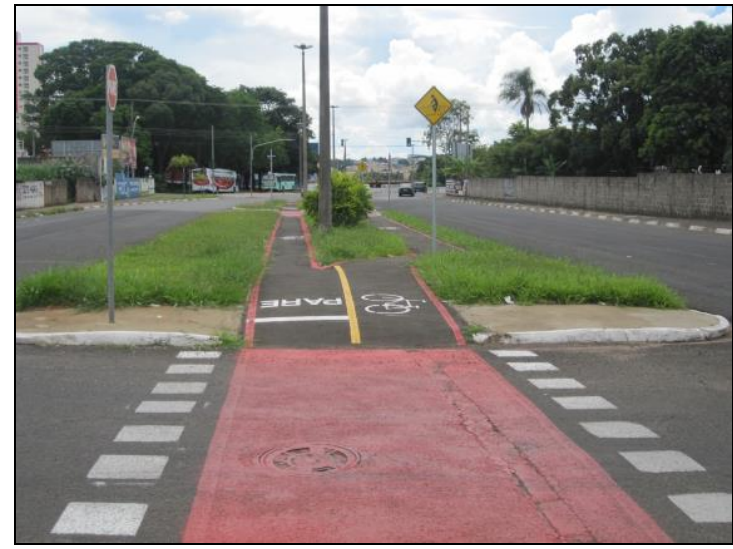

Figura 4.32 - Trecho intermediário com ida e volta juntos.

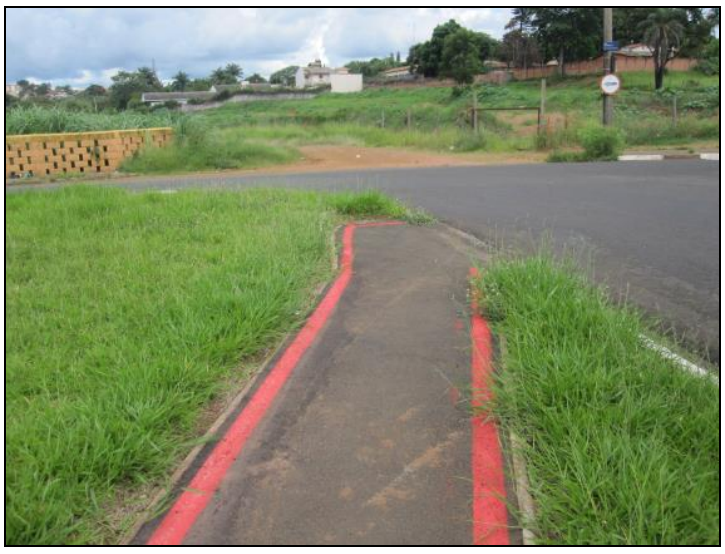

Figura 4.33 - Extremidade da ciclovia distante da Estação Rodoviária.

\section{$\underline{\text { Fluxo de bicicletas }}$}

As contagens do fluxo do tráfego de bicicletas foram realizadas nos períodos de maior movimento: de manhã, das 06:30 às 09:00 h, no meio do dia, das 11:30 às 13:30, e à tarde, das 17:00 às 19:00 h. Na Tabela 4.6 estão relacionados os valores dos fluxos horários encontrados.

Tabela 4.6 - Valores do volume horário (bicicleta/hora).

\begin{tabular}{ccccccccc}
\hline \multicolumn{3}{c}{ Na ciclovia } & \multicolumn{3}{c}{ Fora da ciclovia } & \multicolumn{3}{c}{ Total } \\
\hline Manhã & $\begin{array}{c}\text { Meio } \\
\text { do dia }\end{array}$ & Tarde & Manhã $\begin{array}{c}\text { Meio } \\
\text { do dia }\end{array}$ & Tarde & Manhã & $\begin{array}{c}\text { Meio } \\
\text { do dia }\end{array}$ & Tarde \\
\hline 0,0 & $\begin{array}{c}0,0 \\
\text { Média }=0,3\end{array}$ & 1,0 & 2,0 & $\begin{array}{c}7,5 \\
\text { Média }=5,3\end{array}$ & 6,5 & 2,0 & 7,5 & 7,5 \\
& & \multicolumn{4}{c}{ Média $=5,6$} & \\
\hline
\end{tabular}

Os valores da Tabela 4.6 permitem inferir que:

- O número de ciclistas é muito pequeno; em média, nos horários de maior movimento, uma bicicleta a cada 10,7 minutos.

- $5,4 \%$ utilizam a ciclovia e $94,6 \%$ não utilizam.

\section{Pesquisa com ciclistas}

Dos dez ciclistas que não utilizavam a ciclovia, um (10\%) respondeu que usava a bicicleta para passear e/ou fazer exercícios e nove $(90 \%)$ por outro motivo (trabalhar, estudar, fazer compras, encontrar com amigos, etc.). Todos (100\%) 
disseram que era melhor utilizar a direita da via da pista oposta porque não tinham que parar nos cruzamentos para dar a preferência a outros veículos e que era perigoso e demorado entrar e sair da ciclovia, uma vez que tinham que cruzar/ "cortar" fluxos veiculares.

Não foram entrevistados ciclistas que utilizavam a ciclovia, pois a quantidade é ínfima.

\section{Pesquisa com moradores da vizinhança}

Dos dez moradores da vizinhança entrevistados, nove $(90 \%)$ responderam que não foi importante a Prefeitura ter implantado a ciclovia, uma vez que ela tem pouco uso, e que os recursos deveriam ter sido gastos em outros benefícios para a região.

Um deles (10\%) respondeu que foi importante a Prefeitura ter implantado a ciclovia para que seja utilizada como espaço para a prática de exercícios e de lazer.

\section{$\underline{\text { Avaliação do segmento }}$}

Os seguintes pontos são relevantes no tocante ao segmento 5:

- A implantação da ciclovia é questionável do ponto de vista econômico, uma vez que o tráfego de bicicletas no trecho do sistema viário onde ela se situa é muito pequeno.

- A implantação da ciclovia é questionável do ponto de vista político, pois a maioria dos moradores da vizinhança não aprova a obra.

- A visão da minoria absoluta dos moradores que aprovam a ciclofaixa é que ela constitui um espaço para a prática de exercícios e de lazer e não para deslocamentos por motivo de trabalho, estudo, compras, etc. - o que se comprova na prática, pois a maioria dos usuários utiliza a mesma para a prática de exercícios e de lazer.

- O projeto de ciclovia bidirecional no canteiro central não atende às aspirações dos usuários que se deslocam por motivo de trabalho, estudo, 
compras, etc., pois esses, na sua maioria, por razões de segurança e praticidade, optam por trafegar do lado direito das pistas do tráfego motorizado. Para eles o indicado seria implantar ciclofaixas unidirecionais do lado direito das duas pistas com sentidos contrários.

- Não há impacto no trânsito, pois a ciclovia se situa no canteiro central de uma via e a preferência nos cruzamentos é dos veículos motorizados e dos pedestres.

- Como a ciclovia é nova, as condições do pavimento, a sinalização e a conservação da mesma são bastante satisfatórias.

\subsection{Caracterização e avaliação do segmento 6}

\section{Caracterização física e operacional}

Trata-se de ciclovia bidirecional situada ao lado de um dos acostamentos da Rodovia Luiz Augusto de Oliveira, tem 1.350 metros de extensão, 3,20 metros de largura e declividade máxima de 3\%.

O pavimento é de asfalto.

Quando se localiza ao lado do acostamento da rodovia é separada da mesma por guia comum; do outro lado não há guia ou linha demarcatória. Nos outros trechos não há guia e nem linha demarcatória externa. A separação das faixas é feita com linha divisória vermelha.

As sinalizações vertical e horizontal não são adequadas; em particular, a separação dos fluxos deveria ser feita com linha de cor amarela e não vermelha.

O estado geral de conservação é regular.

Como não há cruzamentos com outras vias, os ciclistas se deslocam sem necessidade de parar para dar passagem a outros veículos ou pedestres.

Na Figura 4.34 é mostrado o trajeto deste segmento. 


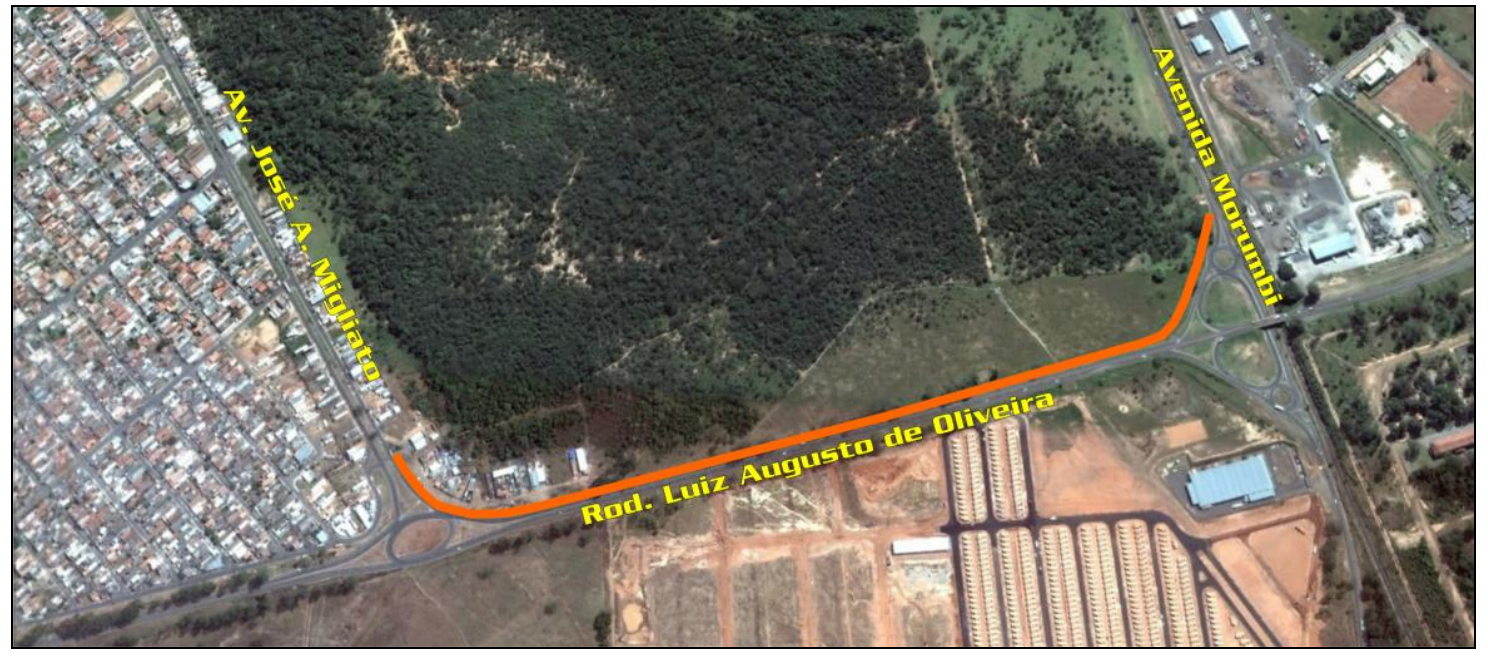

Figura 4.34 - Trajeto do segmento 6 .

Nas Figuras 4.35 a 4.38 são mostrados diferentes aspectos deste segmento.

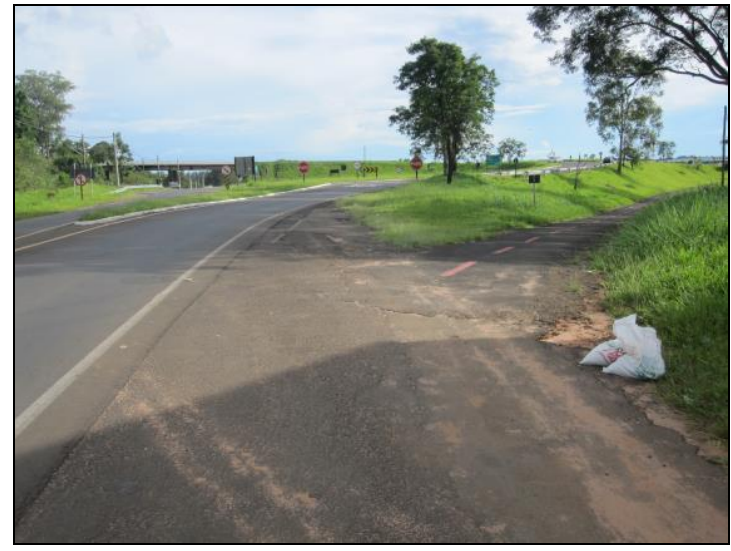

Figura 4.35 - Extremidade da ciclovia junto à Rodovia São Carlos - Broa.

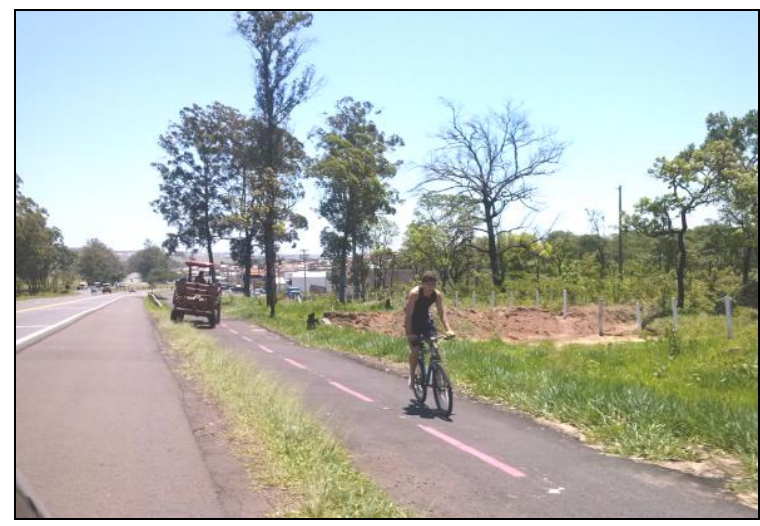

Figura 4.37 - Vista geral da ciclovia em trecho sem guia separadora do acostamento

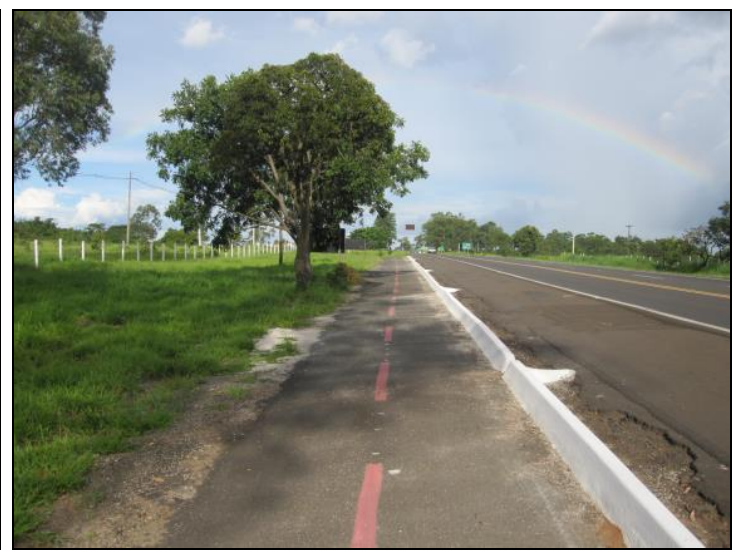

Figura 4.36 - Aspecto geral da ciclovia em trecho com guia separadora do acostamento.

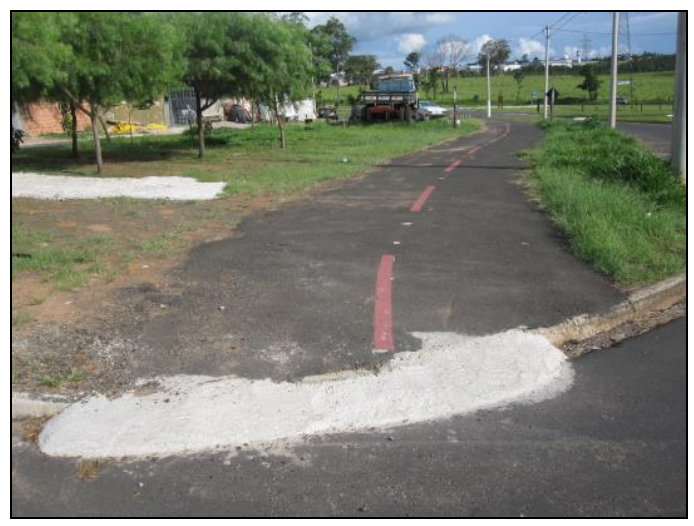

Figura 4.38 - Vista geral da sinalização da ciclovia 


\section{$\underline{\text { Fluxo de bicicletas }}$}

As contagens do fluxo do tráfego de bicicletas foram realizadas nos períodos de maior movimento: de manhã, das 06:30 às 09:00 h, no meio do dia, das 11:30 às 13:30, e à tarde, das 17:00 às 19:00 h. Na Tabela 4.7 estão relacionados os valores dos fluxos horários encontrados.

Tabela 4.7 - Valores do volume horário (bicicleta/hora).

\begin{tabular}{ccccccccc}
\hline & \multicolumn{4}{c}{ Na ciclovia } & \multicolumn{3}{c}{ Fora da ciclovia } & \multicolumn{2}{c}{ Total } & \\
\hline Manhã & $\begin{array}{c}\text { Meio } \\
\text { do dia }\end{array}$ & Tarde & Manhã $\begin{array}{c}\text { Meio } \\
\text { do dia }\end{array}$ & Tarde & Manhã & $\begin{array}{r}\text { Meio } \\
\text { do dia }\end{array}$ & Tarde \\
\hline 3,6 & $\begin{array}{c}6,0 \\
\text { Média }=7,0\end{array}$ & 11,5 & 0,4 & 0,0 & 0,0 & 4,0 & 6,0 & 11,5 \\
& & \multicolumn{2}{c}{ Média $=0,1$} & & Média $=7,1$ & \\
\hline
\end{tabular}

Os valores da Tabela 4.7 permitem inferir que:

- O número de ciclistas é pequeno; em média, nos horários de maior movimento, uma bicicleta a cada 8,5 minutos.

- $98,6 \%$ utilizam a ciclovia e 0,4\% não utilizam.

\section{$\underline{\text { Pesquisa com ciclistas }}$}

Todos os dez ciclistas que utilizavam a ciclovia (100\%) disseram que usavam a bicicleta para trabalhar, estudar, fazer compras, etc.

Não foram entrevistados ciclistas que não utilizavam a ciclovia, pois a quantidade é ínfima.

\section{Pesquisa com moradores da vizinhança}

Dos dez moradores da vizinhança entrevistados, nove (90\%) responderam que foi importante a Prefeitura ter implantado a ciclovia para dar mais segurança e conforto aos ciclistas.

Um deles (10\%) disse que não foi importante e que os ciclistas poderiam continuar utilizando os acostamentos da rodovia.

\section{Avaliação do segmento}


Os seguintes pontos são relevantes no tocante ao segmento 6:

- Apesar do tráfego de bicicletas no trecho do sistema viário onde se situa a ciclovia ser muito pequeno, a implantação da mesma é aceitável sob a ótica socioeconômica por razões de segurança (os ciclistas não tem que utilizar o acostamento de rodovia onde a velocidade dos veículos é alta) e comodidade (os ciclistas não precisam vencer rampa íngreme em uma das extremidades).

- A implantação da ciclovia tem amplo apoio dos moradores da vizinhança, o que the confere viabilidade política.

- A ciclovia somente é utilizada para deslocamentos por motivo de motivo de trabalho, estudo, compras, etc., pois constitui um segmento de ciclovia situado em área não urbanizada.

- Não há impacto no trânsito.

- As condições do pavimento, a sinalização e a conservação da ciclovia não são satisfatórias.

\subsection{Caracterização e avaliação do segmento 7}

\section{Caracterização física e operacional}

É constituído de ciclovia bidirecional situada no canteiro central da Avenida Comendador Alfredo Maffei. Tem extensão de 1.700 metros e largura de 2,70 metros. O perfil longitudinal é praticamente plano.

O pavimento é de concreto.

A demarcação da ciclovia é feita com linhas contínuas de cor vermelha e os fluxos são separados por linha amarela.

O trecho possui adequada sinalização vertical e horizontal e se encontra em bom estado.

Os ciclistas devem parar em todos os cruzamentos com vias transversais. 
Na Figura 4.39 é mostrado o trajeto do segmento 7.

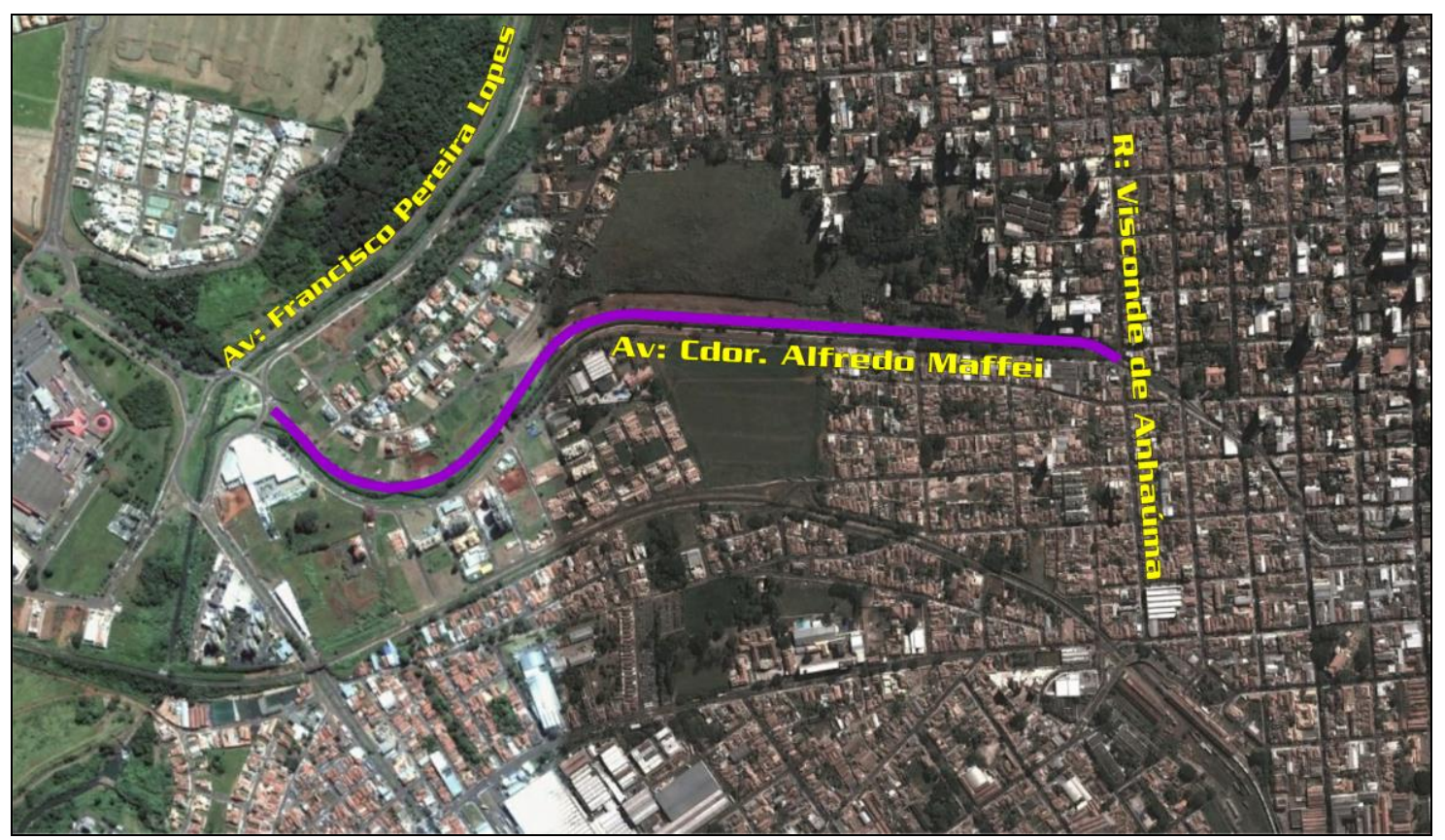

Figura 4.39 - Trajeto do segmento 7.

As figuras 4.40 a 4.46 mostram diferentes aspectos deste segmento.

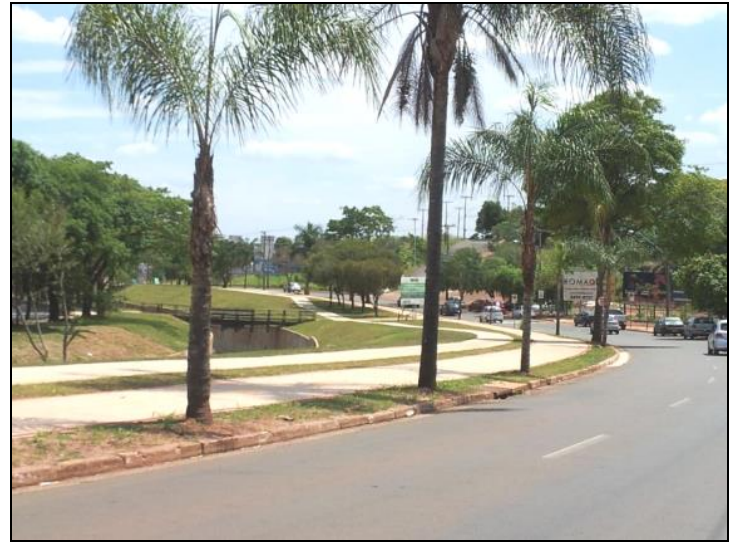

Figura 4.40 - Rio canalizado, ciclovia, passeio para pedestres e rua.

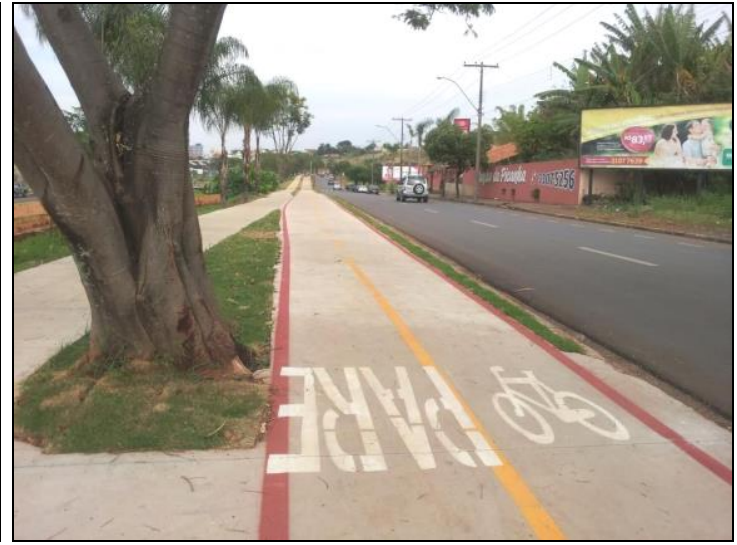

Figura 4.41 - Aspecto geral da ciclovia e da sinalização. 


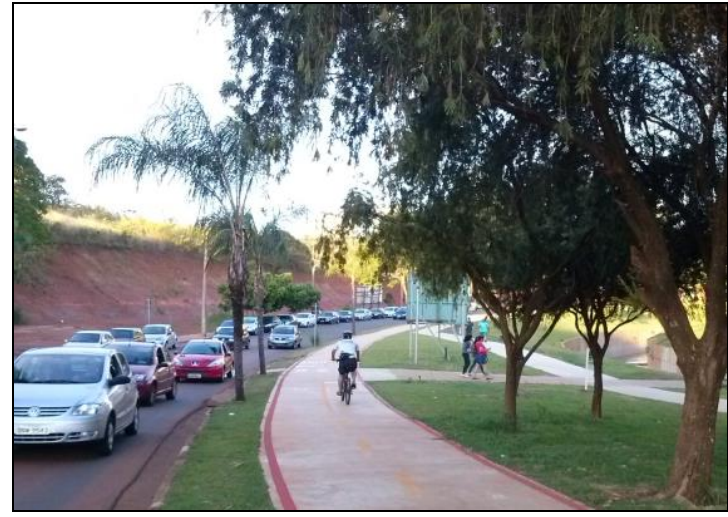

Figura 4.42 - Ciclovia e rua paralela com, fluxo intenso.
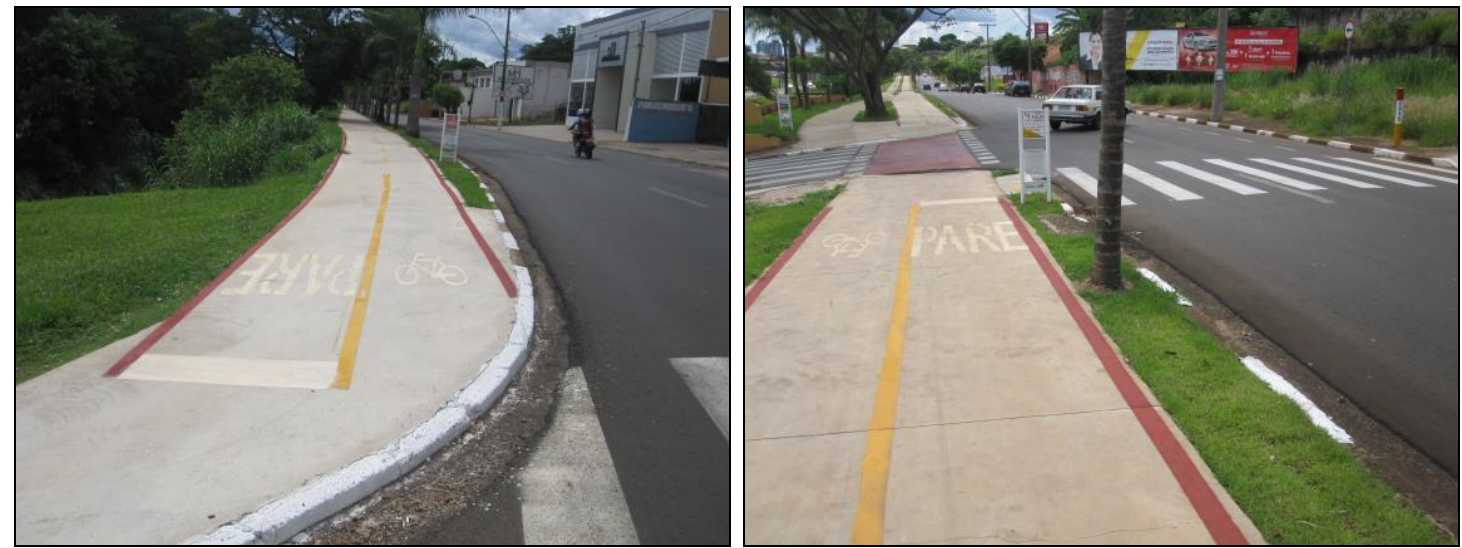

Figura 4.44 - Extremidade da ciclovia mais distante do Shopping Center.

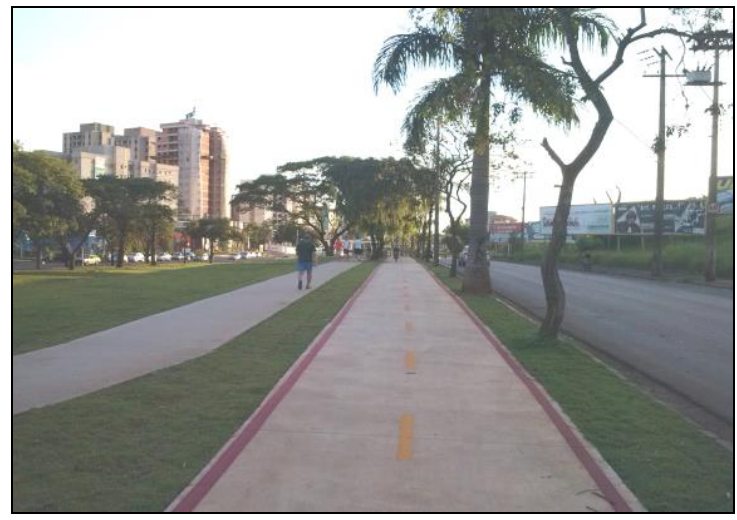

Figura 4.43 - Passeio para pedestres ao lado da ciclovia.
Figura 4.45 - Sinal de parada obrigatória no cruzamento com via transversal.

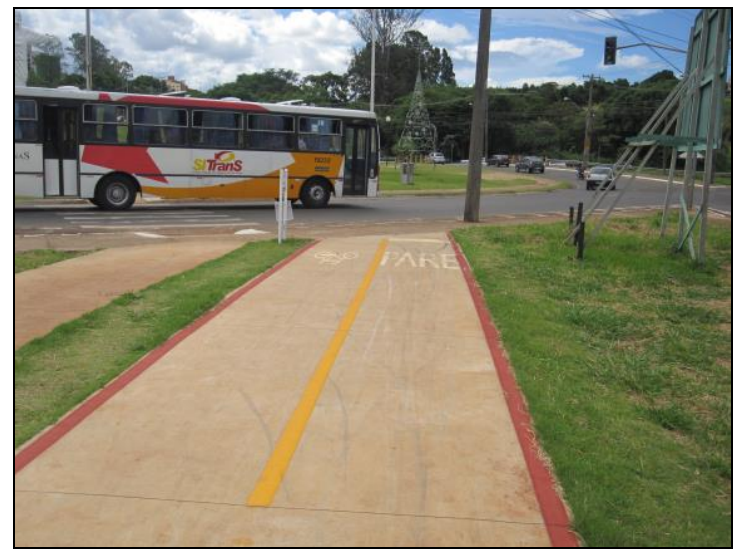

Figura 4.46 - Extremidade da ciclovia próxima do Shopping Center. 


\section{$\underline{\text { Fluxo de bicicletas }}$}

As contagens do fluxo do tráfego de bicicletas foram realizadas nos períodos de maior movimento em todas as ciclovias: de manhã, das 06:30 às 09:00 h, no meio do dia, das 11:30 às 13:30, e à tarde, das 17:00 às 19:00 h. Na Tabela 4.8 estão relacionados os valores dos fluxos horários encontrados.

Tabela 4.8 - Valores do volume horário (bicicleta/hora).

\begin{tabular}{|c|c|c|c|c|c|c|c|c|}
\hline \multicolumn{3}{|c|}{ Na ciclovia } & \multicolumn{3}{|c|}{ Fora da ciclovia } & \multicolumn{3}{|c|}{ Total } \\
\hline Manhã & $\begin{array}{l}\text { Meio } \\
\text { do dia }\end{array}$ & Tarde & Manhã & $\begin{array}{l}\text { Meio } \\
\text { do dia }\end{array}$ & Tarde & Manhã & $\begin{array}{l}\text { Meio } \\
\text { do dia }\end{array}$ & Tarde \\
\hline 1,2 & 3,5 & 23,0 & 0,8 & 2,5 & 7,5 & 2,0 & 6,0 & 30,5 \\
\hline \multicolumn{3}{|c|}{ Média = 9,2 } & \multicolumn{3}{|c|}{ Média = 3,6 } & \multicolumn{3}{|c|}{ Média $=12,8$} \\
\hline
\end{tabular}

Os valores da Tabela 4.8 permitem inferir que:

- O número de ciclistas é pequeno; em média, nos horários de maior movimento, uma bicicleta a cada 4,7 minutos.

- $71,9 \%$ utilizam a ciclovia e $28,1 \%$ não utilizam.

\section{$\underline{\text { Pesquisa com ciclistas }}$}

Dos dez ciclistas que utilizavam a ciclovia, oito (80\%) responderam que usavam a bicicleta para passear e/ou fazer exercícios e dois (20\%) por outro motivo (trabalhar, estudar, fazer compras, encontrar com amigos, etc.).

Dos dez ciclistas que não utilizavam a ciclovia, um (10\%) responderam que usavam a bicicleta para passear e/ou fazer exercícios e nove (90\%) por outro motivo (trabalhar, estudar, fazer compras, encontrar com amigos, etc.). Todos (100\%) disseram que era melhor utilizar a direita das vias normais porque não tinham que parar nos cruzamentos para dar a preferência a outros veículos e pedestres e que era perigoso e demorado entrar e sair da ciclovia, uma vez que tinham que cruzar/ "cortar" fluxos veiculares.

\section{Pesquisa com moradores da vizinhança}


Todos os dez moradores da vizinhança entrevistados, portanto $100 \%$, responderam que foi importante a Prefeitura ter implantado a ciclovia, pois ela, associada à pista de caminhada que foi construída ao lado, constitui um valioso espaço para a prática de exercícios e de lazer.

\section{Avaliação do segmento}

Os seguintes pontos são relevantes no tocante ao segmento 7:

- A implantação da ciclovia é justificável do ponto de vista socioeconômico, uma vez que ela constitui um valioso espaço para a prática de exercícios e de lazer e está situada em uma área que proporciona total condição de segurança para os usuários.

- A implantação da ciclovia tem amplo apoio dos moradores da vizinhança, o que lhe confere viabilidade política.

- A visão dos moradores é que ciclovia constitui um espaço para a prática de exercícios e de lazer e não para deslocamentos por motivo de trabalho, estudo, compras, etc. - o que se comprova na prática, pois a maioria dos usuários utiliza a mesma para a prática de exercícios e de lazer.

- O projeto de ciclovia bidirecional no canteiro central não atende às aspirações dos usuários que se deslocam por motivo de trabalho, estudo, compras, etc., pois esses, na sua maioria, por razões de segurança e praticidade, optam por trafegar do lado direito das pistas do tráfego motorizado. Para eles o indicado seria implantar ciclofaixas unidirecionais do lado direito das duas pistas com sentidos contrários.

- Não há impacto no trânsito, pois a ciclovia se situa no canteiro central de uma via e a preferência nos cruzamentos é dos veículos motorizados e dos pedestres.

- Como a ciclovia é nova, as condições do pavimento, a sinalização e a conservação da mesma são bastante satisfatórias. 


\subsection{Avaliação geral do sistema cicloviário de São Carlos}

Com relação ao sistema cicloviário de São Carlos, as seguintes observações são pertinentes:

- A implantação dos segmentos 1, 5 e 6 é questionável do ponto de vista socioeconômico, uma vez que o tráfego de bicicletas em todos eles é muito pequeno, e, também sob a ótica política, pois a maioria dos moradores da vizinhança não aprova a ciclovia/ciclofaixa.

- A implantação dos segmentos 2 e 7 em canteiros centrais amplos de vias, é justificável do ponto de vista socioeconômico, uma vez que constituem espaço para a prática de exercícios e lazer, e também sob a ótica política, pois a maioria dos moradores da vizinhança aprova a ciclovia.

- Ainda que o fluxo de bicicletas seja muito baixo, a implantação do segmento 6 é justificável do ponto de vista socioeconômico, pois proporciona maior segurança e comodidade para os ciclistas uma vez que evita que tenham que utilizar o acostamento de trecho rodoviário e subir rampa íngreme em um dos sentidos de percurso.

- A implantação da ciclovia do segmento 4 é questionável do ponto de vista socioeconômico, uma vez que o tráfego de bicicletas é muito pequeno, e, também sob a ótica política, pois a maioria dos moradores da vizinhança não aprova a ciclovia. No tocante a ciclofaixa, a situação é ainda pior, pois como se situa em um trecho em rampa acentuada, a maioria absoluta dos ciclistas entende como mais seguro empurrar as suas bicicletas na calçada; e a maioria absoluta da população rejeita a mesma.

- Excetuando o segmento 6, todos os outros apresentam problemas técnicos graves que levam os ciclistas a trafegar do lado direito das pistas comuns de tráfego, não utilizando a ciclovia/ciclofaixa por razões de segurança e praticidade.

- De maneira geral, nos segmentos 1,2,3,5 e 7 as condições do pavimento, a sinalização e a conservação são satisfatórias. Nos segmentos 4 e 6, não. 
Os seguintes índices globais são verificados em São Carlos:

- População = 236.457 habitantes.

- Extensão do sistema cicloviário $=15.300$ metros de ciclovia/ciclofaixa (considerando em separado cada sentido de fluxo).

- Soma dos valores médios dos fluxos de bicicletas nos períodos de maior movimento nas vias onde se localizam os segmentos cicloviários $=107,90$ bicicletas por hora.

- Relação entre a extensão do sistema cicloviário e a população $=64,71$ metros de ciclovia/ciclofaixa por mil habitantes.

- Relação entre a soma dos fluxos de bicicletas e a população $=45,63$ bicicletas por hora por cem mil habitantes.

- Relação entre a soma dos fluxos de bicicletas e a extensão do sistema cicloviário $=7,05$ bicicletas por hora por km de ciclovia/ciclofaixa.

Esses valores quando comparados com os das outras cidades estudadas (Araraquara e Rio Claro) permite fazer as seguintes inferências:

- São Carlos tem posição intermediária no tocante à extensão do sistema cicloviário: São Carlos tem 2,30 vezes mais que Araraquara e Rio Claro, 1,18 vezes mais que São Carlos.

- São Carlos tem posição intermediária no tocante à soma dos fluxos de bicicletas: São Carlos tem 1,76 vezes mais que Araraquara e Rio Claro tem 6,30 vezes mais que São Carlos.

- São Carlos tem posição intermediária no tocante à relação entre a extensão do sistema viário e a população: São Carlos tem 2,16 vezes mais que Araraquara e Rio Claro tem 1,41 vezes mais que São Carlos.

- São Carlos tem posição intermediária no tocante à relação entre a soma dos fluxos de bicicletas e a população: São Carlos tem 1,66 vezes mais que Araraquara e Rio Claro tem 7,57 vezes mais que São Carlos. 
- São Carlos tem a menor relação entre a soma dos fluxos de bicicletas e a extensão do sistema cicloviário: Araraquara tem 1,30 vezes mais e Rio Claro, 5,35 . 


\section{5- CARACTERIZAÇÃo E AVALIAÇÃo DO SISTEMA CICLOVIÁRIO DE RIO CLARO}

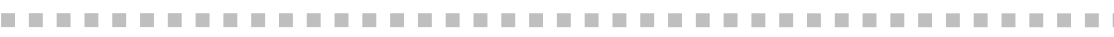

\subsection{Informações gerais do município}

Localizado na região central do Estado de São Paulo, o Município de Rio Claro possui 196.821 mil habitantes. A cidade encontra-se a uma distância rodoviária de 157 km da cidade de São Paulo, capital do Estado.

Na Tabela 5.1 são relacionados alguns dados gerais do município.

Tabela 5.1 - Dados gerais do município de Rio Claro.

Fonte: IBGE (2013), DENATRAN (2013).

\begin{tabular}{lc}
\hline População & 196.821 \\
\hline Índice de Desenvolvimento Humano Municipal - IDHM & $\mathbf{0 , 8 0 3}$ \\
\hline Renda per capita (em reais correntes) & $\mathbf{8 4 0 , 3 9}$ \\
\hline Frota Veicular & 142.322 \\
\hline Índice de Motorização & $\mathbf{7 2 , 3 1}$ \\
Índice de Gini* & $\mathbf{0 , 5 0 8 1}$ \\
\hline *Indice de Gini da renda domiciliar per capita (quanto mais próximo de zero \\
maior a distribuição da renda; quanto mais próximo de & 1 \\
distribuição da renda). &
\end{tabular}

A cidade de Rio Claro tem como característica vias urbanas que são norteadas a partir do núcleo central. A área central é formada por bairros antigos, próximos à estação e ao pátio ferroviário, sendo que as ruas estreitas e com grande fluxo de veículos motorizados e não motorizados. Nas áreas periféricas, as vias têm largura maior. A malha urbana é estritamente ortogonal.

Os principais eixos viários da cidade têm grandes extensões e convergem para a região de fundo de vale (Córrego da Servidão), onde está localizada a Avenida Visconde de

Rio

Claro. 
$\mathrm{Na}$ Figura 5.1 estão indicadas as principais vias no mapa geral da cidade.

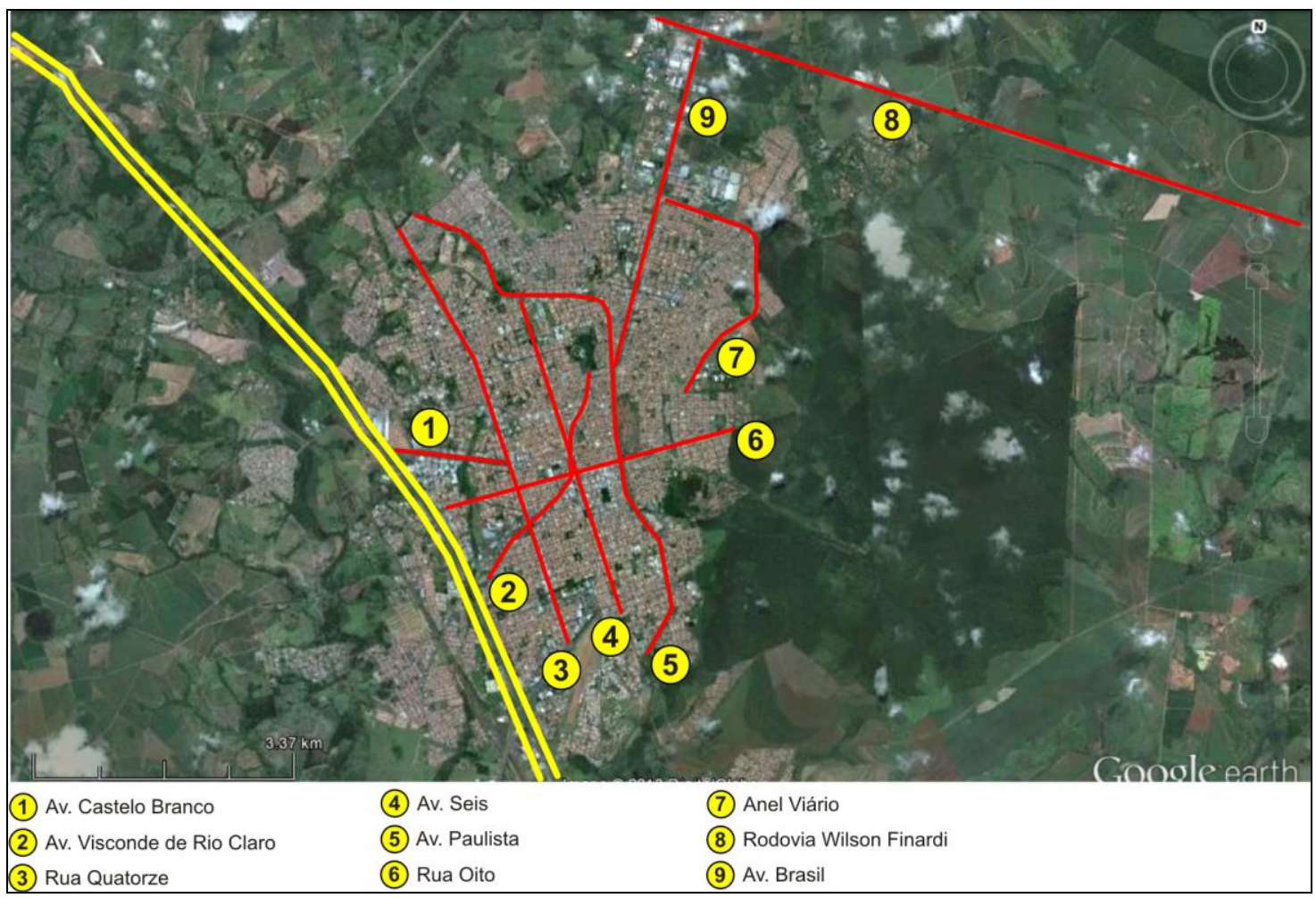

Figura 5.1 - Mapa com as principais vias da cidade de Rio Claro.

Rio Claro tem certa tradição no uso de bicicletas como meio de transporte, sobretudo em razão da topografia plana e do grande número de operários, sendo tida uma das cidades do país com maior extensão do sistema cicloviário.

A cidade também conta com inúmeros bicicletários na região central da cidade. Nas Figuras 5.2 e 5.3 são mostrados dois desses equipamentos urbanos.

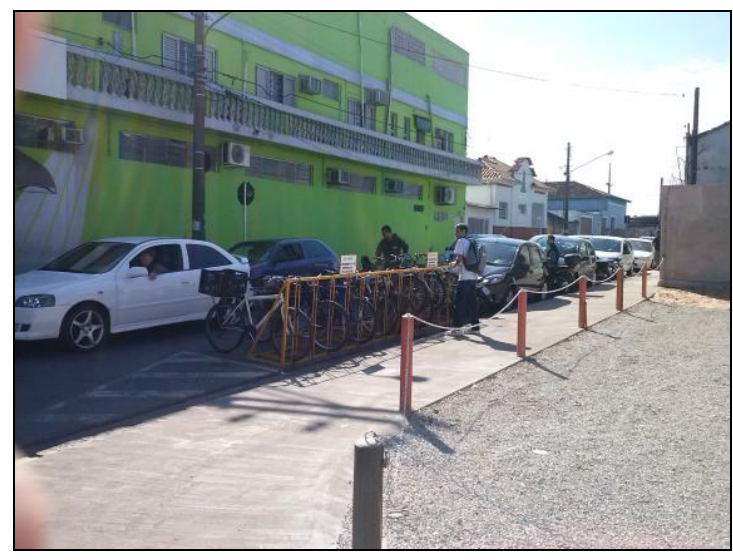

Figura 5.2 - Bicicletário na Avenida Dez.

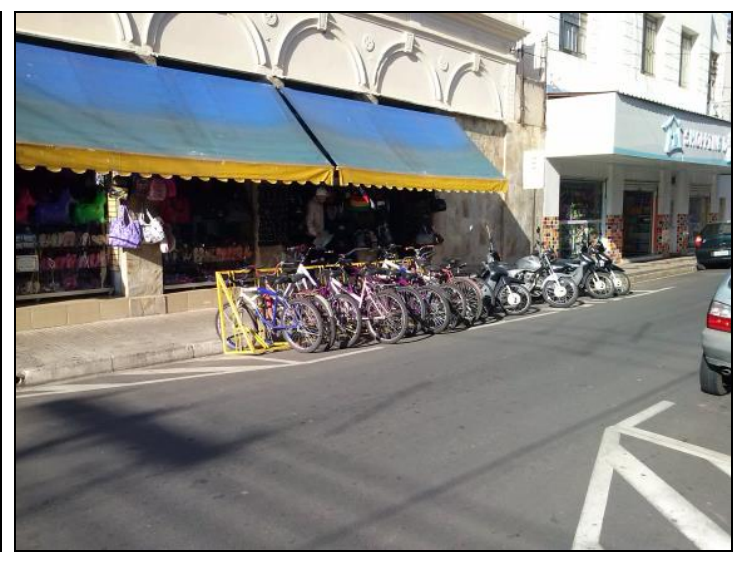

Figura 5.3 - Bicicletário na Rua Dois. 
De acordo com a Prefeitura de Rio Claro, o município conta com cerca de 140 mil bicicletas e, diariamente, são realizados cerca de 40 mil deslocamentos. Da ordem de $20 \%$ da população utiliza bicicletas para se locomover.

\subsection{Sistema Cicloviário}

O sistema cicloviário da cidade tem 13.420 metros de extensão física (18.020 metros considerando em separado cada sentido de movimento), sendo constituído dos seguintes sete segmentos:

- Segmento 1 - Ciclofaixa unidirecional situada nas ruas Seis e Dr. Eloy Chaves; tem extensão de 2.000 metros.

- Segmento 2 - Ciclofaixa unidirecional situada na Rua Seis A; tem extensão de 2.200 metros.

- Segmento 3 - Ciclovia bidirecional situada no canteiro central da Rua Três A e da Avenida Brasil, tem extensão de 3.400 metros.

- Segmento 4 - Ciclovia bidirecional situada na Avenida Quinze Jw e na Estrada de Ipeúna; tem extensão de 1.200 metros. 2,0 metros.

- Segmento 5 - Ciclofaixa unidirecional situada na Avenida Vinte e Quatro; tem extensão de 440 metros.

- Segmento 6 - Ciclofaixa unidirecional situada na Rua Um A, Avenida Dez e Rua Dois; tem extensão de 2.440 metros.

- Segmento 7 - Ciclofaixa unidirecional situada na Rua Um; tem extensão de 1.740 metros.

Na Figura 5.4 é mostrada a localização desses sete segmentos cicloviários. 


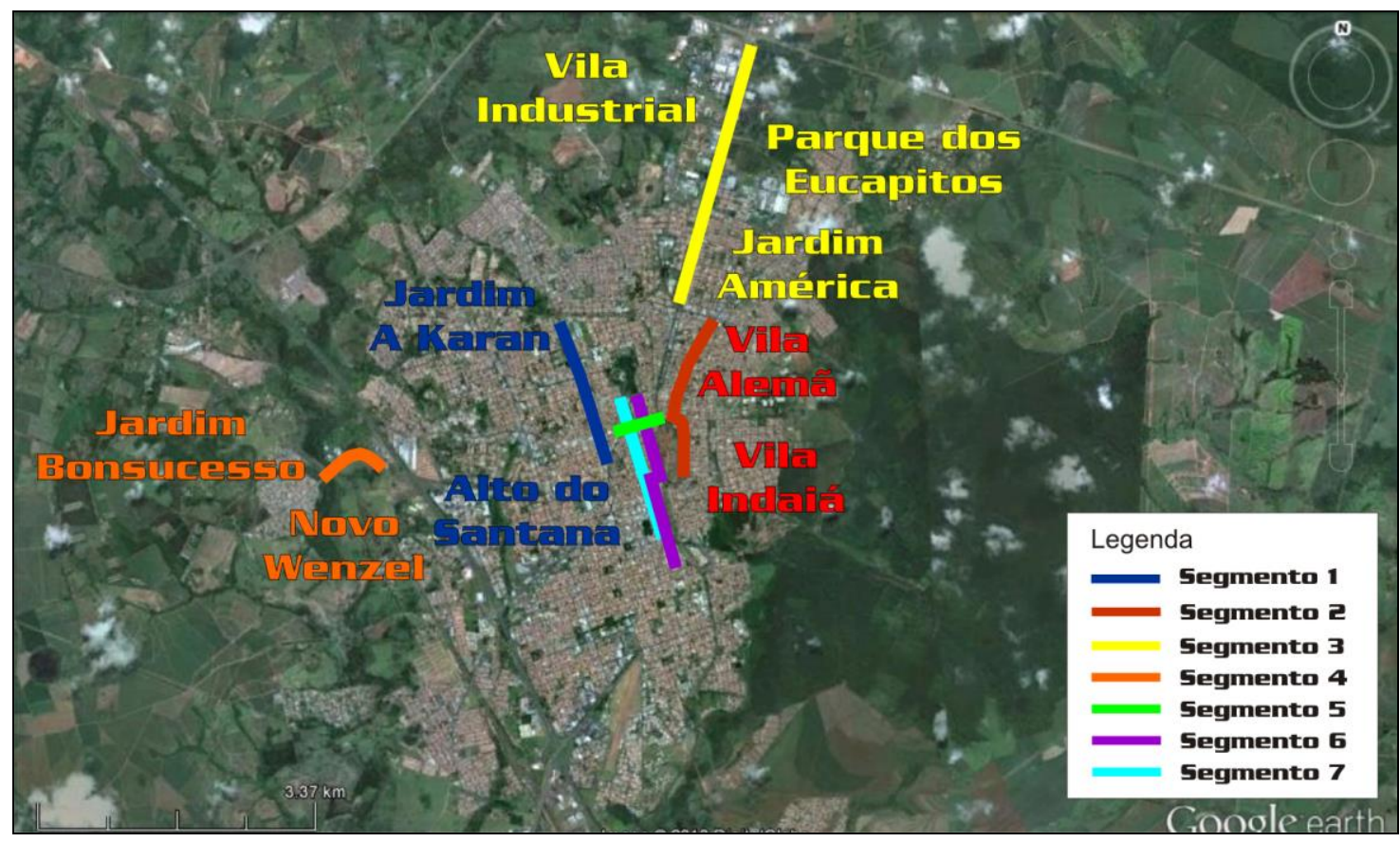

Figura 5.4 - Localização dos segmentos cicloviários de Rio Claro.

\subsection{Caracterização e avaliação do segmento 1}

\section{Caracterização física e operacional}

O segmento 1 consiste de ciclofaixa unidirecional posicionada do lado direito no sentido de circulação e está situado na ruas Dr. Eloy Chaves e Seis. A ciclofaixa tem 1,5 metros de largura, extensão de 2.000 metros e perfil longitudinal com pequena declividade.

Na Figura 5.5 é mostrado o trajeto desse segmento. 


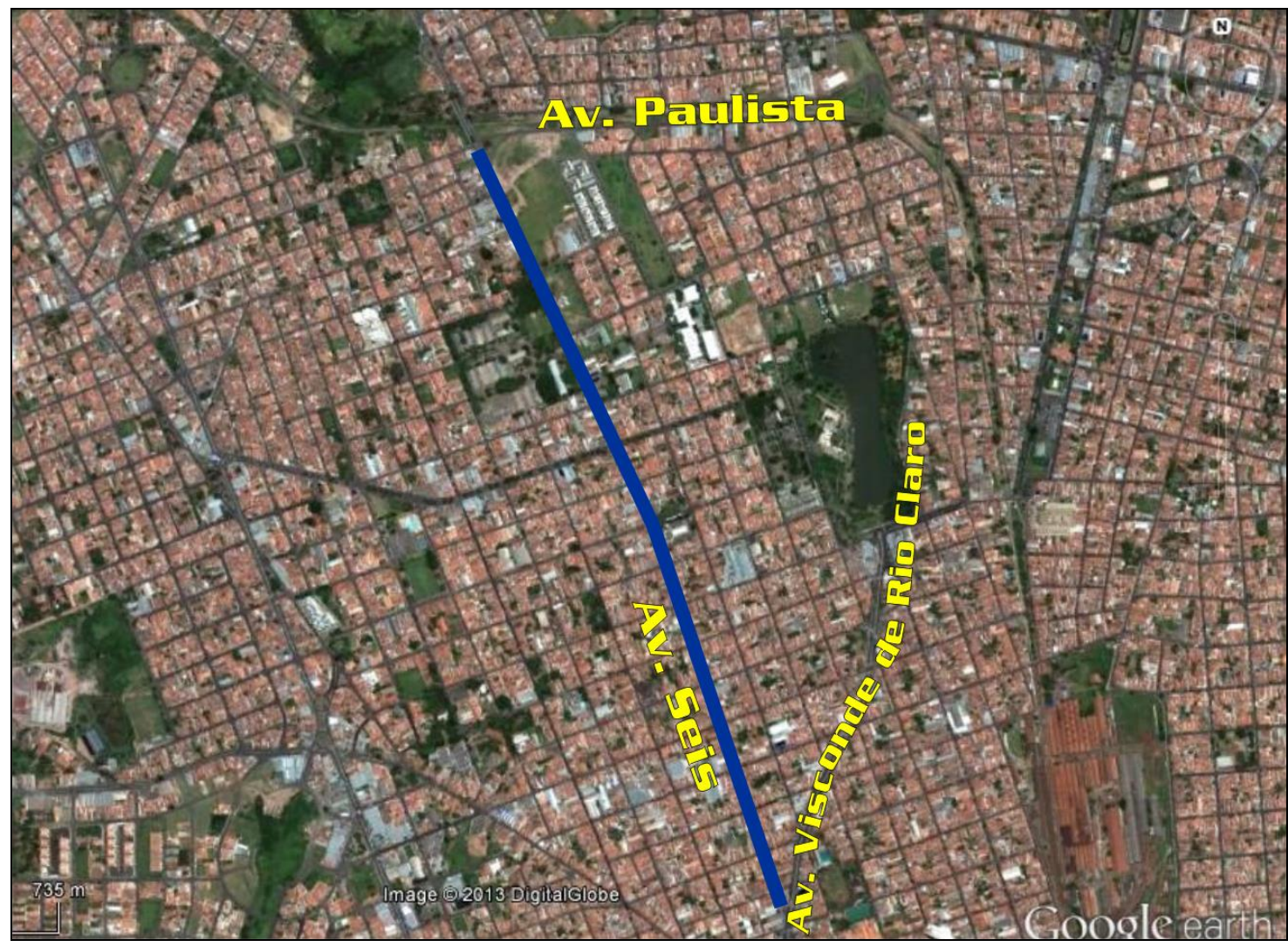

Figura 5.5 - Trajeto do segmento 1.

Na Figura 5.6 é mostrada a seção transversal do sistema viário no segmento 1.

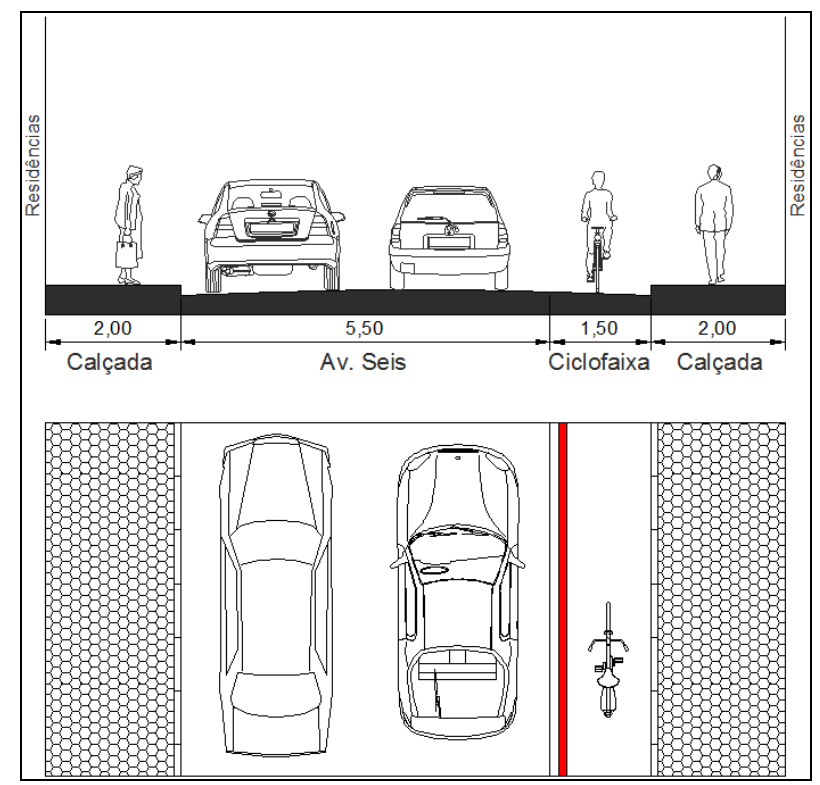

Figura 5.6 - Seção transversal do sistema viário no segmento 1.

Nas Figuras 5.7 a 5.10 são mostrados diferentes aspectos do segmento 1. 


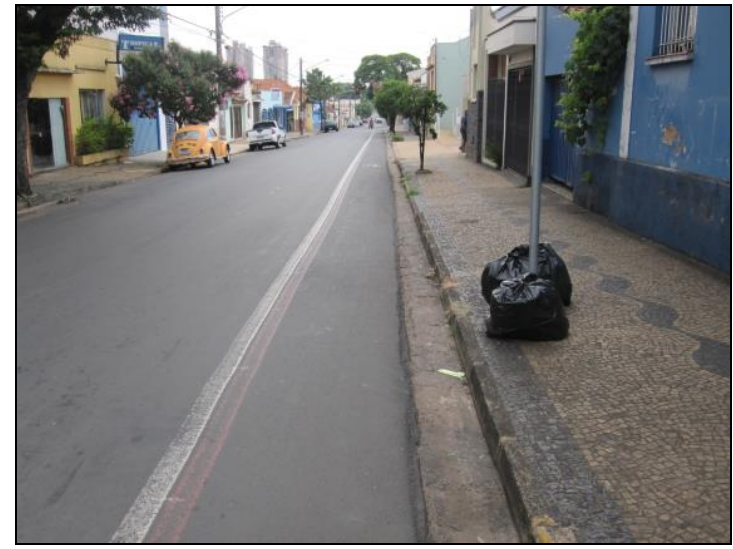

Figura 5.7 - Vista geral da ciclovia.

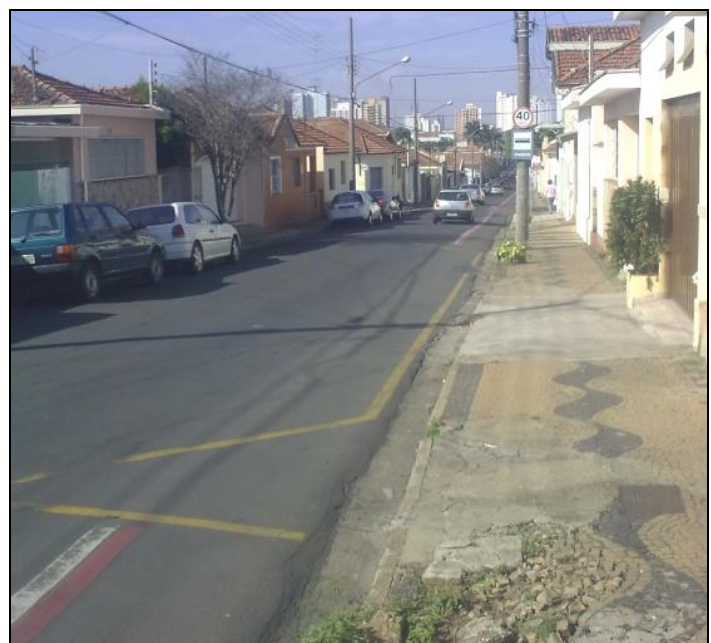

Figura 5.9 - Forma de sinalização nos pontos de ônibus.

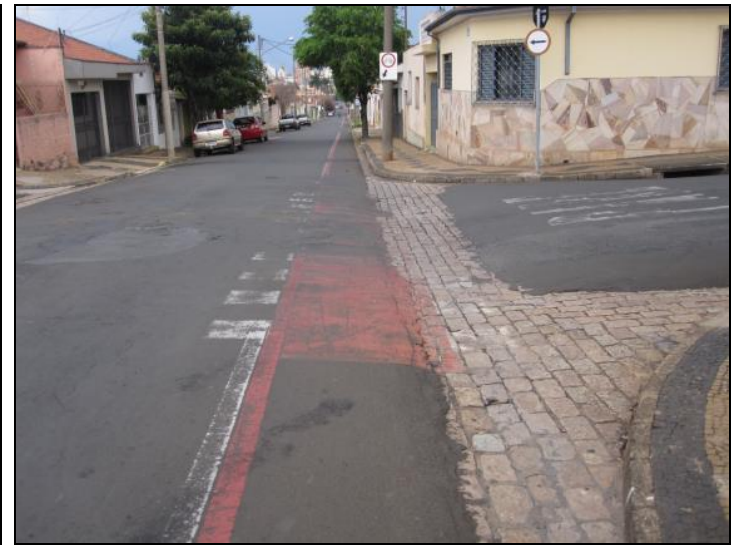

Figura 5.8 - Sinalização típica em um cruzamento já bastante apagada.

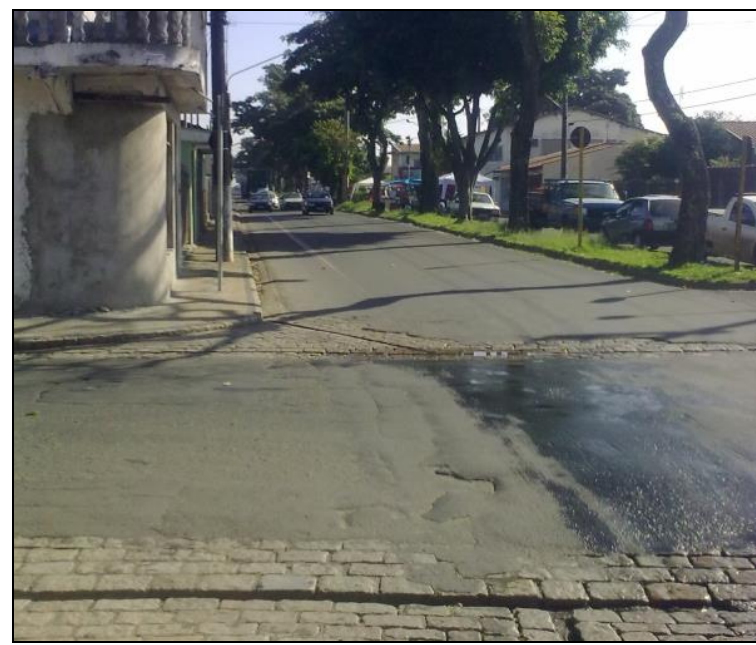

Figura 5.10 - Falta de sinalização em um cruzamento.

A separação do tráfego motorizado é feita com linha vermelha, do lado da ciclofaixa, contigua à linha branca, do lado das faixas de tráfego motorizado.

A sinalização horizontal é adequada e se encontra em bom estado em muitos trechos, mas desgastada em outros, sobretudo nos cruzamentos com outras ruas. A sinalização vertical é satisfatória na maior parte do percurso, e se encontra em estado razoável.

De maneira geral, o pavimento encontra-se em bom estado; somente em alguns poucos locais se observam defeitos.

O estado geral de conservação é satisfatório. 
Como a ciclofaixa está situada em uma via preferencial, os ciclistas trafegam sem necessidade de parar nos cruzamentos não semaforizados.

A presença da ciclovia tem impacto bastante negativo no trânsito, praticamente reduzindo as faixas de tráfego da pista de duas para uma, considerando estacionamento de um único lado.

\section{Fluxo de bicicletas}

As contagens do fluxo do tráfego de bicicletas foram realizadas nos períodos de maior movimento em todas as ciclovias: de manhã, das 06:30 às 09:00 h, no meio do dia, das 11:30 às 13:30, e à tarde, das 17:00 às 19:00 h. Na Tabela 5.2 estão relacionados os valores dos fluxos horários encontrados.

Tabela 5.2 - Valores do volume horário (bicicleta/hora).

\begin{tabular}{|c|c|c|c|c|c|c|c|c|}
\hline \multicolumn{3}{|c|}{ Na ciclovia } & \multicolumn{3}{|c|}{ Fora da ciclovia } & \multicolumn{3}{|c|}{ Total } \\
\hline Manhã & $\begin{array}{l}\text { Meio } \\
\text { do dia }\end{array}$ & Tarde & Manhã & $\begin{array}{c}\text { Meio } \\
\text { do dia }\end{array}$ & Tarde & Manhã & $\begin{array}{c}\text { Meio } \\
\text { do dia }\end{array}$ & Tarde \\
\hline 71,6 & 32,5 & 36,5 & 6,4 & 3,5 & 6,0 & 78,0 & 36,0 & 42,5 \\
\hline \multicolumn{3}{|c|}{ Média = 46,9 } & \multicolumn{3}{|c|}{ Média = 5,3 } & \multicolumn{3}{|c|}{ Média $=52,2$} \\
\hline
\end{tabular}

Os valores da Tabela 5.2 permitem inferir que:

- O fluxo de bicicletas é razoável; em média, nos horários de maior movimento, uma bicicleta a cada 1,1 minutos.

- $89,8 \%$ utilizam a ciclovia e $10,2 \%$ não utilizam.

\section{$\underline{\text { Pesquisa com ciclistas }}$}

Todos os dez ciclistas que utilizavam a ciclofaixa (100\%) responderam que usavam a bicicleta para trabalhar, estudar, fazer compras, etc. Algumas reclamações frequentes foram: defeitos no pavimento, sinalização deficiente e insegurança nos cruzamentos não semaforizados (os condutores das vias transversais muitas vezes não respeitam a prioridade dos ciclistas que estão na via preferencial). 
Todos os dez ciclistas que não estavam na ciclofaixa responderam que realizariam a conversão à frente.

\section{Pesquisa com moradores da vizinhança}

Dos dez moradores da vizinhança entrevistados, sete (70\%) responderam que a ciclofaixa é importante porque muitas pessoas utilizam bicicletas para se deslocar na cidade.

Três (30\%) disseram que ela era desnecessária e que não deveria existir por atrapalhar muito o trânsito.

\section{Avaliação do segmento}

Os seguintes pontos são relevantes no tocante ao segmento 1:

- A implantação da ciclofaixa é viável do ponto de vista socioeconômico uma vez que o investimento é baixo e o tráfego de bicicletas no segmento significativo.

- A implantação da ciclofaixa é viável sob a ótica política, uma vez que a maioria dos moradores da vizinhança aprova a obra.

- A ciclofaixa é utilizada, sobretudo por necessidade: trabalhar, estudar, fazer compras, etc.

- O projeto da ciclofaixa unidirecional é tecnicamente correto; prova disso é que a maioria absoluta dos ciclistas trafega por ela.

- A presença da ciclovia tem impacto bastante negativo no trânsito, praticamente reduzindo as faixas de tráfego da pista de duas para uma, considerando estacionamento de um único lado.

- As condições do pavimento, a sinalização e a conservação da ciclofaixa não estão satisfatórias.

\subsection{Caracterização e avaliação do segmento 2}


O segmento 2 consiste de ciclofaixa unidirecional posicionada do lado direito no sentido de circulação e está situado na Rua Seis A. A ciclofaixa tem 1,5 metros de largura, extensão de 2.200 metros e perfil longitudinal com pequena declividade.

Na Figura 5.11 é mostrado o trajeto desse segmento.

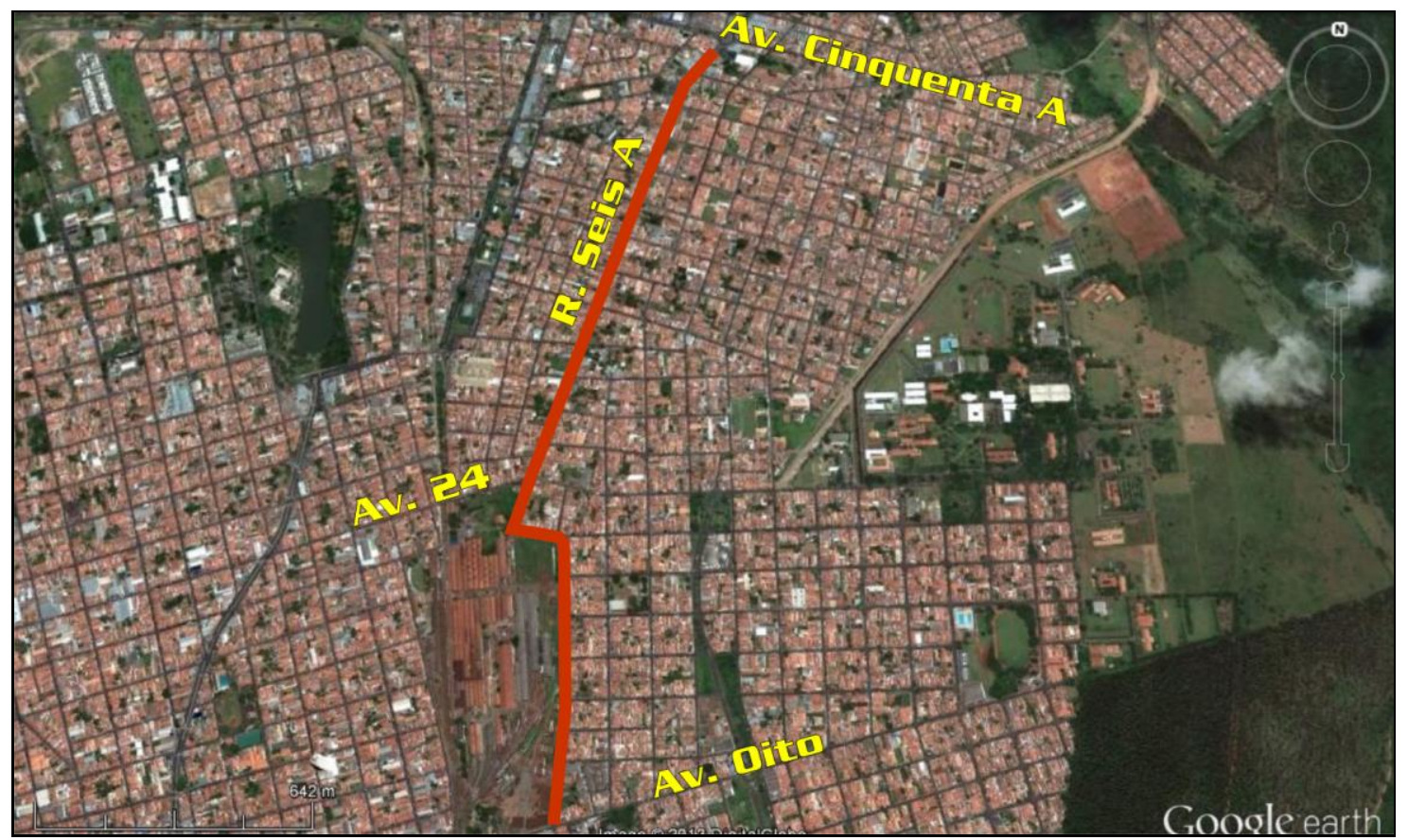

Figura 5.11 - Trajeto do segmento 2.

A seção transversal do sistema viário neste segmento é idêntica a do segmento 1 mostrada na Figura 5.6.

Nas Figuras 5.12 a 5.15 são mostrados diferentes aspectos do segmento 2.

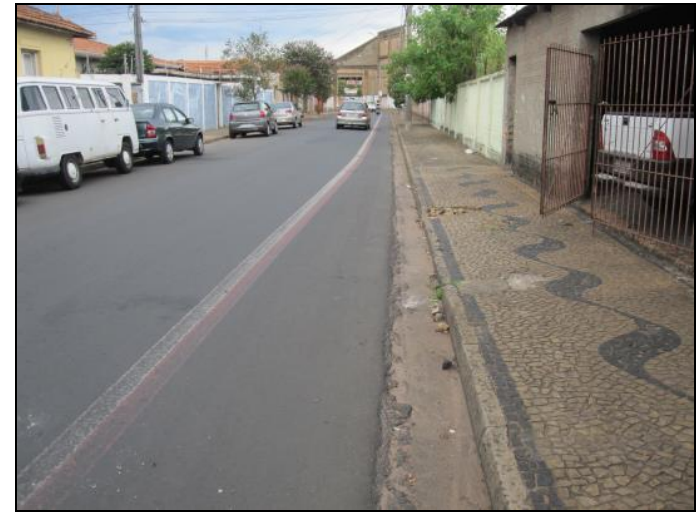

Figura 5.12 - Vista geral da ciclofaixa.

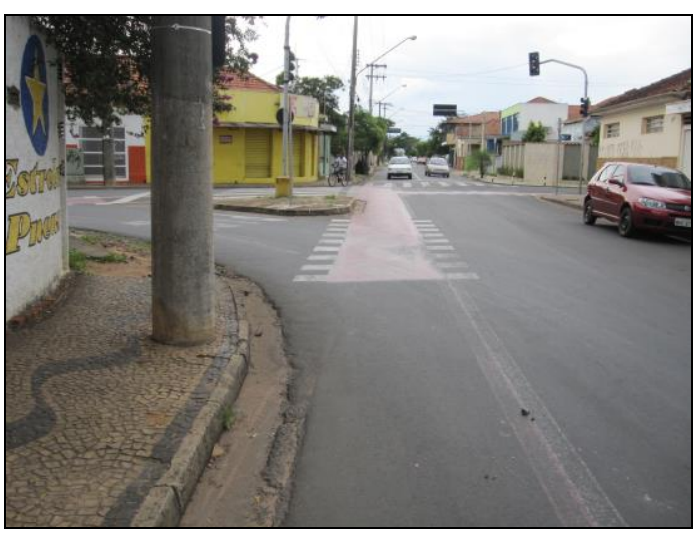

Figura 5.13 - Sinalização típica no cruzamento. 


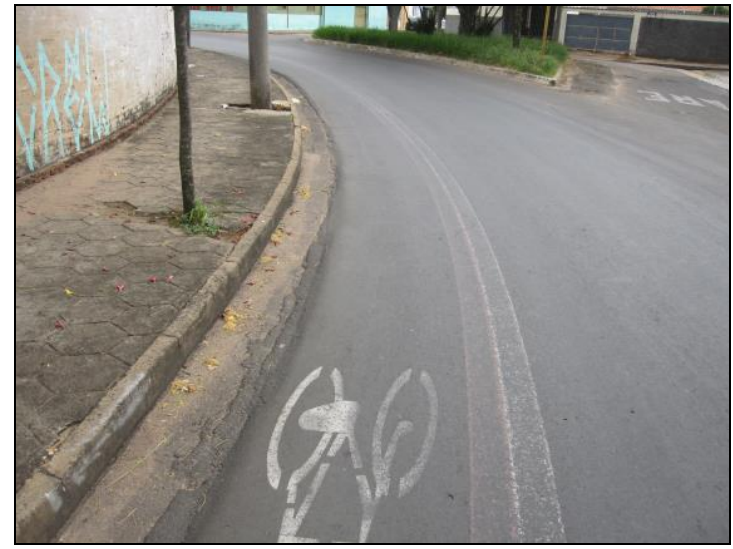

Figura 5.14 - Sinalização desgastada em um trecho em curva.

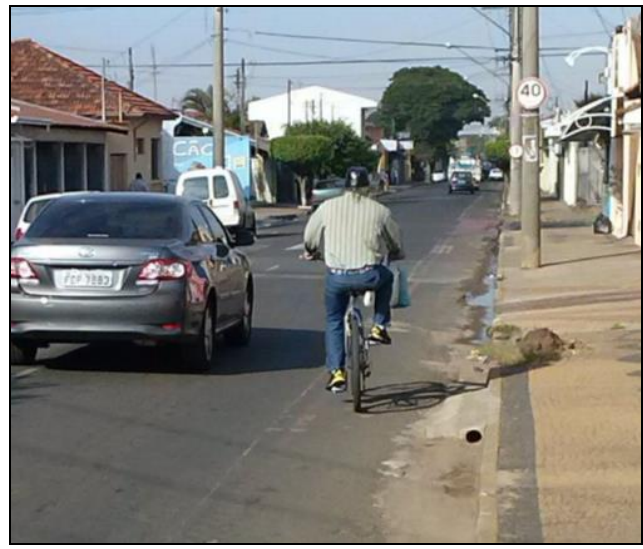

Figura 5.15 - Local com defeito no pavimento.

A separação do tráfego motorizado é feita com linha vermelha, do lado da ciclofaixa, contigua à linha branca, do lado das faixas de tráfego motorizado.

A sinalização horizontal é adequada e se encontra em bom estado em muitos trechos, mas desgastada em outros, sobretudo nos cruzamentos com outras ruas. A sinalização vertical é satisfatória na maior parte do percurso, e se encontra em estado razoável.

De maneira geral, o pavimento encontra-se em bom estado; somente em alguns poucos locais se observam defeitos.

O estado geral de conservação é satisfatório.

Como a ciclofaixa está situada em uma via preferencial, os ciclistas trafegam sem necessidade de parar nos cruzamentos não semaforizados.

A presença da ciclovia tem impacto bastante negativo no trânsito, praticamente reduzindo as faixas de tráfego da pista de duas para uma, considerando estacionamento de um único lado.

\section{Fluxo de bicicletas}

As contagens do fluxo do tráfego de bicicletas foram realizadas nos períodos de maior movimento em todas as ciclovias: de manhã, das 06:30 às 09:00 h, no 
meio do dia, das 11:30 às 13:30, e à tarde, das 17:00 às 19:00 h. Na Tabela 5.3 estão relacionados os valores dos fluxos horários encontrados.

Tabela 5.3 - Valores do volume horário (bicicleta/hora).

\begin{tabular}{|c|c|c|c|c|c|c|c|c|}
\hline \multicolumn{3}{|c|}{ Na ciclovia } & \multicolumn{3}{|c|}{ Fora da ciclovia } & \multicolumn{3}{|c|}{ Total } \\
\hline Manhã & $\begin{array}{l}\text { Meio } \\
\text { do dia }\end{array}$ & Tarde & Manhã & $\begin{array}{l}\text { Meio } \\
\text { do dia }\end{array}$ & Tarde & Manhã & $\begin{array}{l}\text { Meio } \\
\text { do dia }\end{array}$ & Tarde \\
\hline 104,8 & 70,0 & 127,0 & 11,6 & 13,0 & 9,5 & 116,4 & 83,0 & 136,5 \\
\hline \multicolumn{3}{|c|}{ Média = 100,6} & \multicolumn{3}{|c|}{ Média = 11,4 } & \multicolumn{3}{|c|}{ Média $=112,0$} \\
\hline
\end{tabular}

Os valores da Tabela 5.3 permitem inferir que:

- O fluxo de bicicletas é significativo; em média, nos horários de maior movimento, uma bicicleta a cada 32 segundos.

- $89,8 \%$ utilizavam a ciclovia e $10,2 \%$ não utilizavam.

\section{$\underline{\text { Pesquisa com ciclistas }}$}

Todos os dez ciclistas que utilizavam a ciclofaixa (100\%) responderam que usavam a bicicleta para trabalhar, estudar, fazer compras, etc. Algumas reclamações frequentes foram: defeitos no pavimento, sinalização deficiente e insegurança nos cruzamentos não semaforizados (os condutores das vias transversais muitas vezes não respeitam a prioridade dos ciclistas que estão na via preferencial).

Todos os dez ciclistas que não estavam na ciclofaixa responderam que realizariam a conversão à frente.

\section{Pesquisa com moradores da vizinhança}

Dos dez moradores da vizinhança entrevistados, oito (80\%) responderam que a ciclofaixa é importante porque muitas pessoas utilizam bicicletas para se deslocar na cidade.

Dois (20\%) disseram que ela era desnecessária e que não deveria existir por atrapalhar muito o trânsito. 


\section{Avaliação do segmento}

Os seguintes pontos são relevantes no tocante ao segmento 2:

- A implantação da ciclofaixa é viável do ponto de vista socioeconômico uma vez que o investimento é baixo e o tráfego de bicicletas no segmento significativo.

- A implantação da ciclofaixa é viável sob a ótica política, uma vez que a maioria dos moradores da vizinhança aprova a obra.

- A ciclofaixa é utilizada, sobretudo por necessidade: trabalhar, estudar, fazer compras, etc.

- O projeto da ciclofaixa unidirecional é tecnicamente correto; prova disso é que a maioria absoluta dos ciclistas trafega por ela.

- A presença da ciclovia tem impacto bastante negativo no trânsito, praticamente reduzindo as faixas de tráfego da pista de duas para uma, considerando estacionamento de um único lado.

- As condições do pavimento, a sinalização e a conservação da ciclofaixa não estão satisfatórias.

\subsection{Caracterização e avaliação do segmento 3}

O segmento 3 consiste de ciclovia bidirecional situada no amplo canteiro central da Avenida Brasil. A ciclovia tem 2,50 metros de largura, extensão de 3.400 metros e perfil longitudinal plano.

O uso da ciclovia é compartilhado com pedestres fazendo caminhadas.

Na Figura 5.16 é mostrado o trajeto desse segmento. 


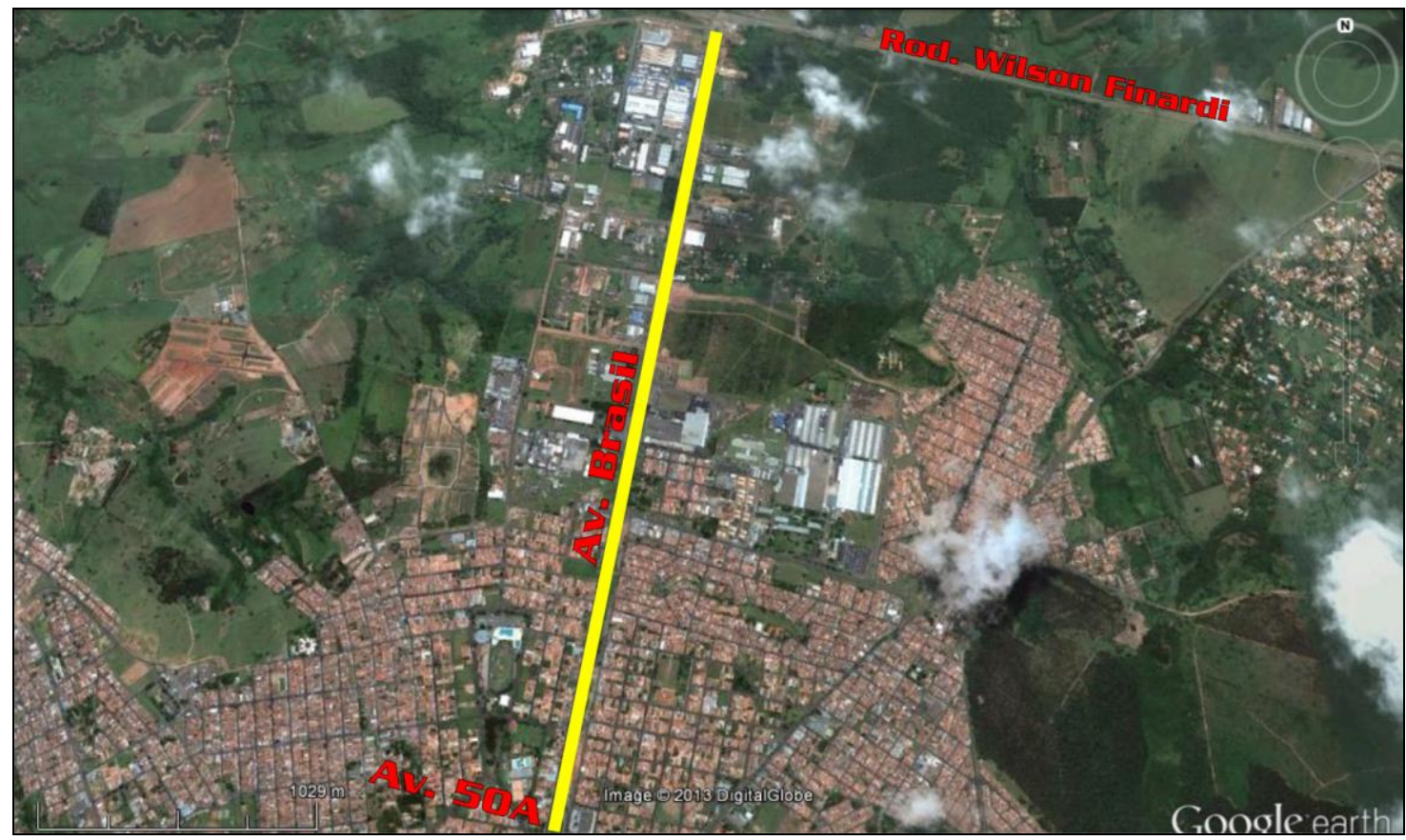

Figura 5.16 - Trajeto do segmento 3.

Na Figura 5.17 é mostrada a seção transversal do sistema viário no segmento.

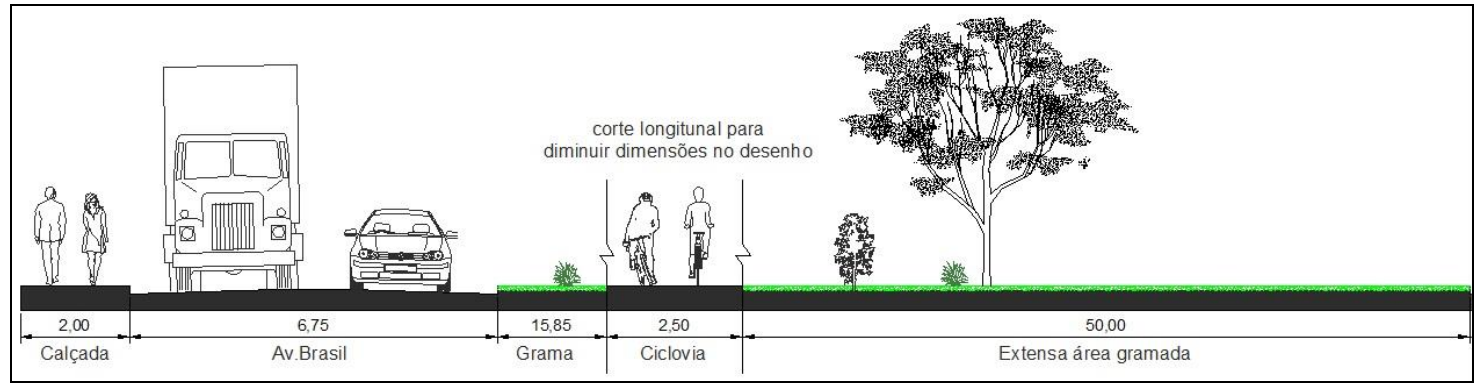

Figura 5.17 - Seção transversal do sistema viário no segmento.

As figuras 5.18 a 5.24 mostram diferentes aspectos deste segmento.

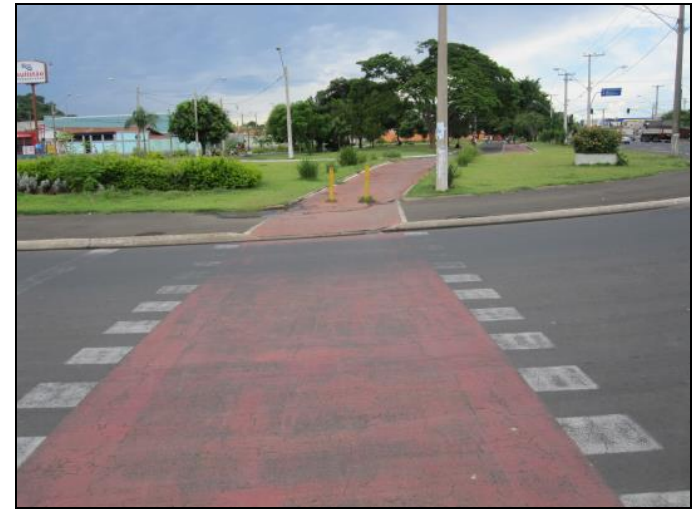

Figura 5.18 - Sinalização em um cruzamento.

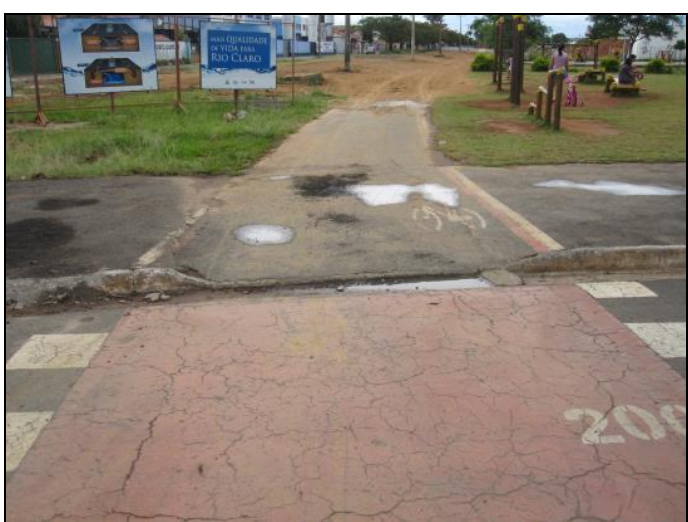

Figura 5.19 - Trecho da ciclovia sem pavimento. 


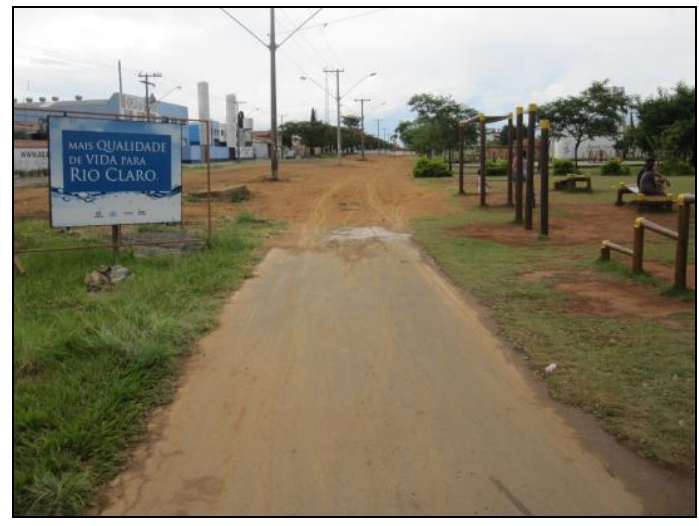

Figura 5.20 - Pista totalmente deteriorada (em terra).

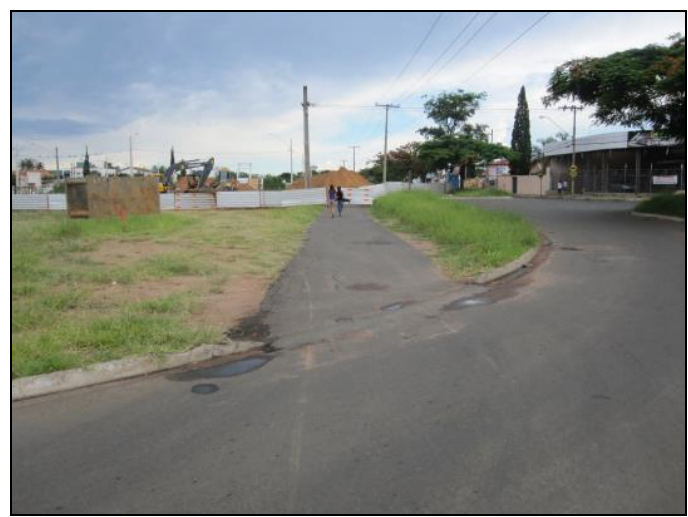

Figura 5.22 - Trecho com má conservação e bloqueio à frente.

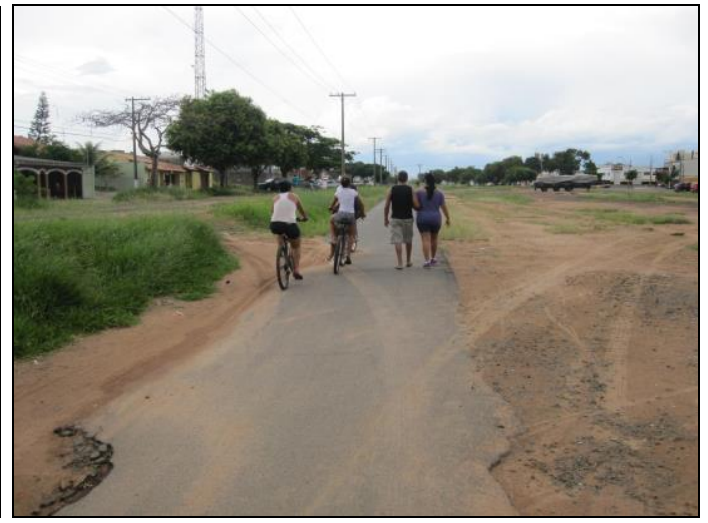

Figura 5.21 - Trecho com má conservação.

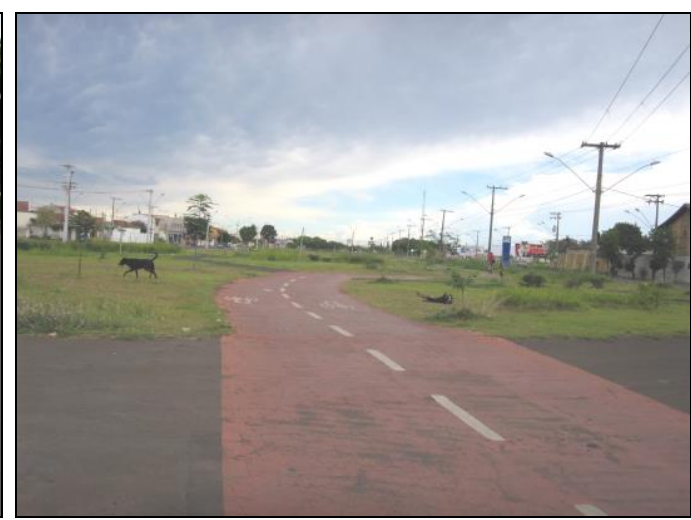

Figura 5.23 - Vista geral da ciclovia em um trecho bem conservado.

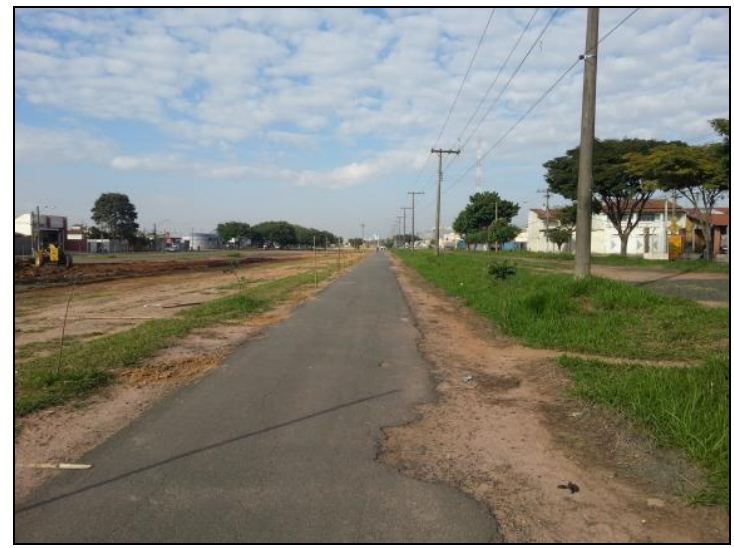

Figura 5.24 - Pista totalmente deteriorada em uma das extremidades.

Apenas em um pequeno trecho a ciclovia é conformada por guia e com linha separadora de fluxos; na maior parte não tem nem linha demarcatória externa e nem linha separadora de fluxos. 
A sinalização vertical é precária e se encontra em processo de deterioração.

A utilização é compartilhada com pedestres.

O estado geral de conservação é insatisfatório, pois há trechos em bom estado

e outros onde se observam os seguintes problemas: falta de pavimento, pavimento com defeitos e vegetação invadindo a pista.

\section{Fluxo de bicicletas}

As contagens do fluxo do tráfego de bicicletas foram realizadas nos períodos de maior movimento em todas as ciclovias: de manhã, das 06:30 às 09:00 h, no meio do dia, das 11:30 às 13:30, e à tarde, das 17:00 às 19:00 h. Na Tabela 5.4 estão relacionados os valores dos fluxos horários encontrados.

Tabela 5.4 - Valores do volume horário (bicicleta/hora).

\begin{tabular}{|c|c|c|c|c|c|c|c|c|}
\hline \multicolumn{3}{|c|}{ Na ciclovia } & \multicolumn{3}{|c|}{ Fora da ciclovia } & \multicolumn{3}{|c|}{ Total } \\
\hline Manhã & $\begin{array}{l}\text { Meio } \\
\text { do dia }\end{array}$ & Tarde & Manhã & $\begin{array}{l}\text { Meio } \\
\text { do dia }\end{array}$ & Tarde & Manhã & $\begin{array}{l}\text { Meio } \\
\text { do dia }\end{array}$ & Tarde \\
\hline 76,8 & 133,5 & 225,5 & 14,0 & 45,5 & 59,0 & 90,8 & 179,0 & 284,5 \\
\hline \multicolumn{3}{|c|}{ Média $=145,3$} & \multicolumn{3}{|c|}{ Média = 39,5 } & \multicolumn{3}{|c|}{ Média $=184,8$} \\
\hline
\end{tabular}

Os valores da Tabela 5.4 permitem inferir que:

- O fluxo de bicicletas é significativo; em média, nos horários de maior movimento, uma bicicleta a cada 19 segundos.

- $78,6 \%$ utilizavam a ciclovia e $21,4 \%$ não utilizavam.

\section{$\underline{\text { Pesquisa com ciclistas }}$}

A maioria dos ciclistas utiliza a ciclofaixa. $80 \%$ deles responderam que usavam a bicicleta para trabalhar, estudar, fazer compras, etc. Uma reclamação recorrente que fizeram é sobre defeitos no pavimento e sinalização deficiente.

Todos os dez ciclistas que não estavam na ciclovia responderam que realizariam viagens curtas e não valia a pena ir até a ciclovia que estava distante. 


\section{Pesquisa com moradores da vizinhança}

Todos os dez moradores da vizinhança (100\%) responderam que foi importante a Prefeitura ter implantado a ciclovia, não somente pela possibilidade de uso por motivo de trabalho, estudo, etc. como também para lazer.

\section{Avaliação do segmento}

Os seguintes pontos são relevantes no tocante ao segmento 3:

- A implantação da ciclovia é totalmente justificável do ponto de vista socioeconômico, tanto pelo grande fluxo de ciclistas se deslocando por motivo de trabalho, estudo e compras, como por constituir um valioso espaço para a prática de exercícios e de lazer (para ciclistas e pedestres) situada em uma área que proporciona total condição de segurança para os usuários.

- A implantação da ciclovia tem amplo apoio dos moradores da vizinhança, o que lhe confere total viabilidade política.

- A visão dos moradores é que ciclovia constitui um importante espaço para a prática de exercícios e de lazer como também para deslocamentos por motivo de trabalho, estudo, compras, etc.

- As características técnicas da ciclovia são totalmente adequadas.

- Não há impacto no trânsito, pois a ciclovia se situa no canteiro central de uma via e a preferência nos cruzamentos é dos veículos motorizados e dos pedestres.

- As condições do pavimento, a sinalização e a conservação da ciclovia são bastante satisfatórias.

\subsection{Caracterização e avaliação do segmento 4}

O segmento 4 consiste de ciclovia bidirecional situada a cerca de 5 metros da borda da pista da rodovia conhecida como Estrada de Ipeúna. A ciclovia tem 1,80 metros de largura e extensão de 1.200 metros. A maior dela apresenta 
rampa acentuada (entre 4 e $6 \%$ ). No trecho em rampa ascendente, os ciclistas empurram as suas bicicletas.

Na Figura 5.25 é mostrado o trajeto desse segmento.

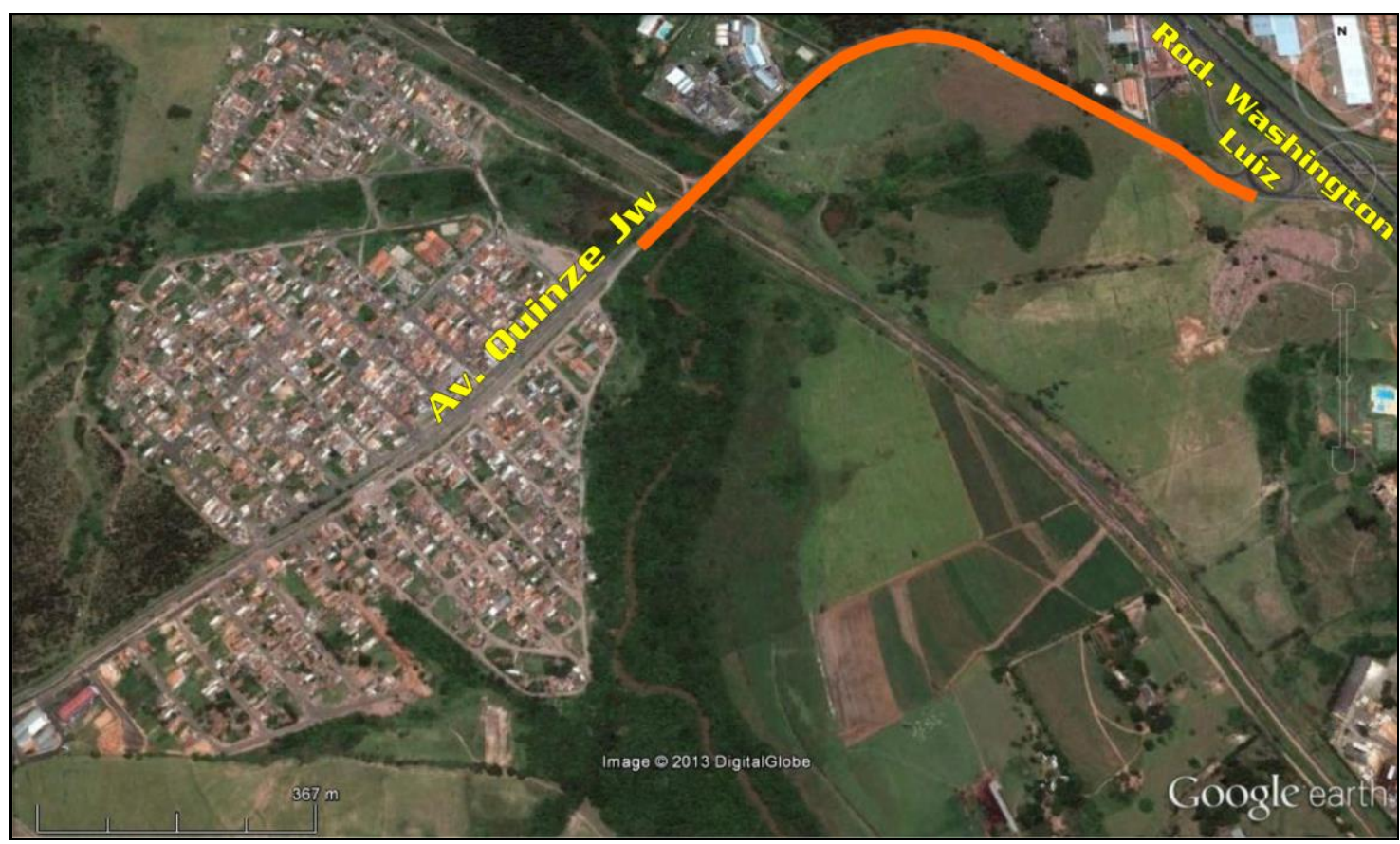

Figura 5.25 - Trajeto do segmento 4.

Nas Figuras 5.26 a 5.31 são mostrados diferentes aspectos deste segmento.

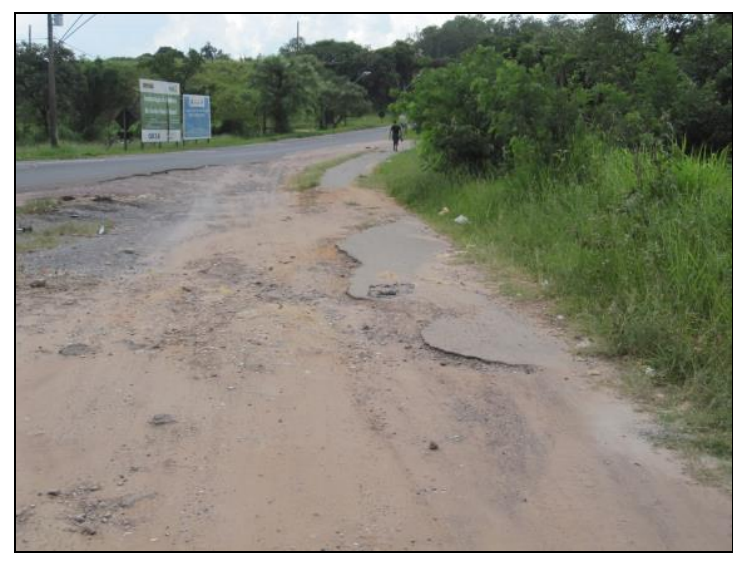

Figura 5.26 - Pista totalmente deteriorada em uma das extremidades.

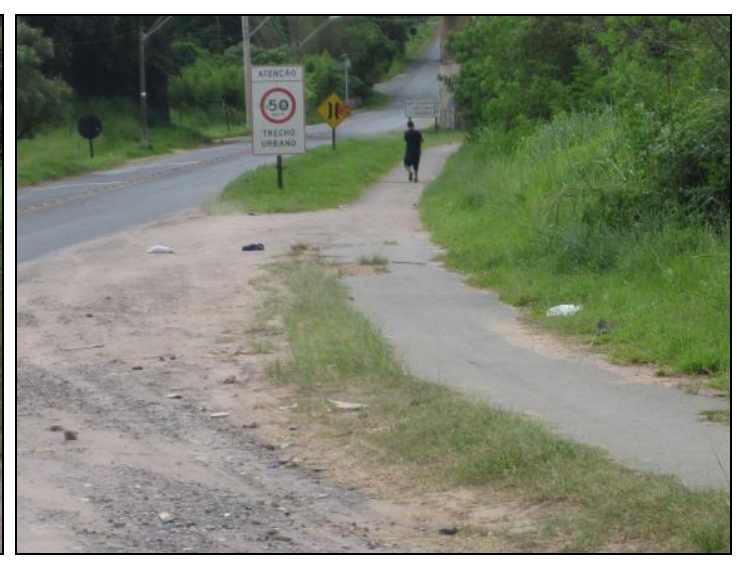

Figura 5.27 - Vegetação e terra invadindo a ciclovia. 


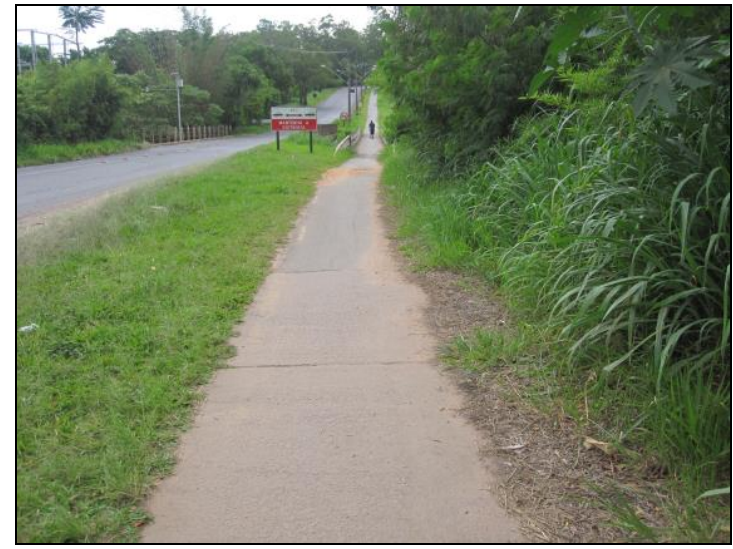

Figura 5.28 - Trecho sem nenhuma sinalização.

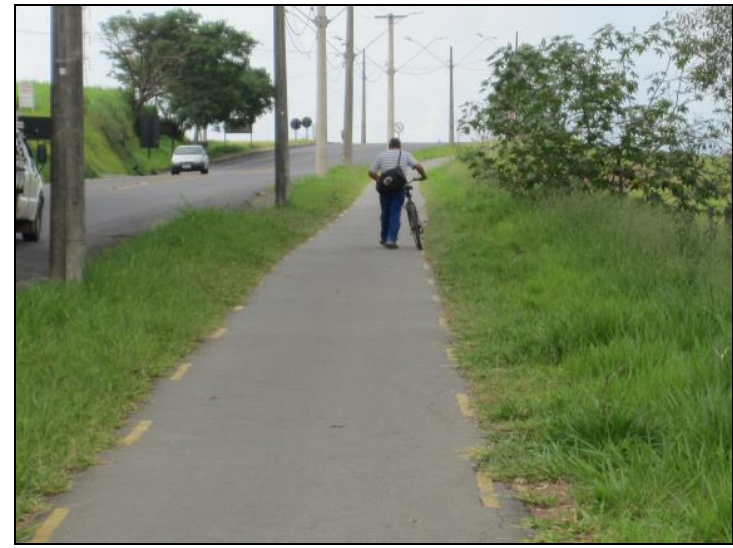

Figura 5.30 - Trecho com sinalização das bordas e ciclista empurrando a bicicleta.

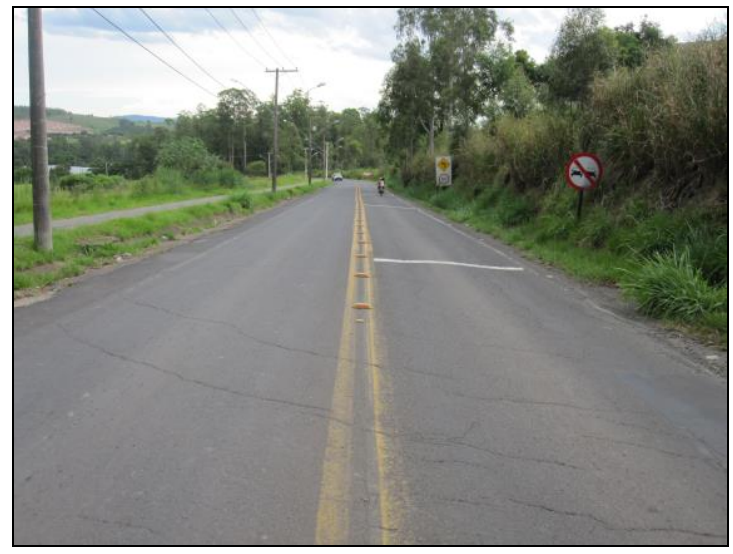

Figura 5.29 - Posição da ciclovia ao lado da rodovia com acostamento estreito.

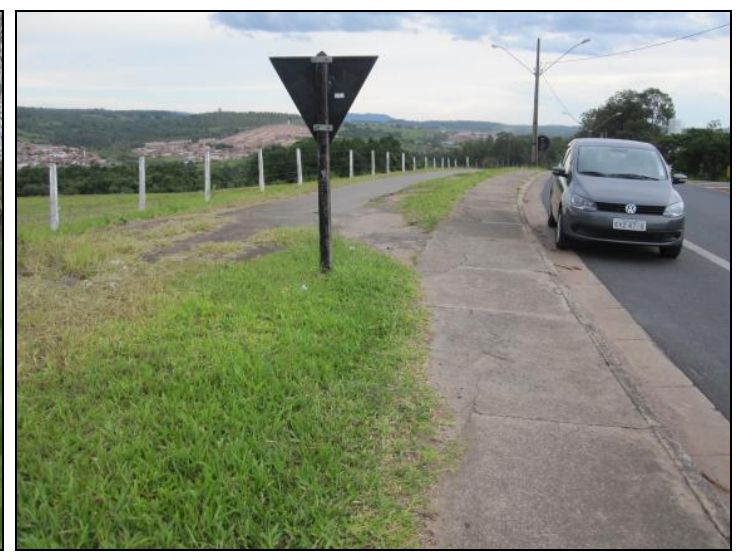

Figura 5.31 - Má conservação e falta de sinalização em uma das extremidades.

A ciclovia não é conformada por nenhum tipo de elemento físico; apenas parte do trecho tem a borda externa delimitada por linha amarela seccionada; não há linha divisória de fluxos; a sinalização vertical é precária e se encontra em processo de deterioração. A sua utilização é compartilhada com pedestres.

O estado geral de conservação é ruim, pois há trechos em que não há mais pavimento e o mato está invadindo a ciclovia.

O pavimento de asfalto encontra-se em estado satisfatório em alguns trechos e bastante deteriorado em outros.

O estado geral de conservação é insatisfatório. 


\section{$\underline{\text { Fluxo de bicicletas }}$}

As contagens do fluxo do tráfego de bicicletas foram realizadas nos períodos de maior movimento em todas as ciclovias: de manhã, das 06:30 às 09:00 h, no meio do dia, das 11:30 às 13:30, e à tarde, das 17:00 às 19:00 h. Na Tabela 5.5 estão relacionados os valores dos fluxos horários encontrados.

Tabela 5.5 - Valores do volume horário (bicicleta/hora).

\begin{tabular}{|c|c|c|c|c|c|c|c|c|}
\hline \multicolumn{3}{|c|}{ Na ciclovia } & \multicolumn{3}{|c|}{ Fora da ciclovia } & \multicolumn{3}{|c|}{ Total } \\
\hline Manhã & $\begin{array}{l}\text { Meio } \\
\text { do dia }\end{array}$ & Tarde & Manhã & $\begin{array}{l}\text { Meio } \\
\text { do dia }\end{array}$ & Tarde & Manhã & $\begin{array}{l}\text { Meio } \\
\text { do dia }\end{array}$ & Tarde \\
\hline 6,8 & 14,0 & 12,5 & 0,8 & 0,0 & 2,5 & 7,6 & 14,0 & 15,0 \\
\hline \multicolumn{3}{|c|}{ Média = 11,1 } & \multicolumn{3}{|c|}{ Média = 1,1 } & \multicolumn{3}{|c|}{ Média = 12,2 } \\
\hline
\end{tabular}

Os valores da Tabela 5.5 permitem inferir que:

- O número de ciclistas é pequeno; em média, nos horários de maior movimento, uma bicicleta a cada $4 \mathrm{~min}$ e $55 \mathrm{seg}$.

- $91,0 \%$ utilizam a ciclovia e 9,0\% não utilizam (utilizam o acostamento da rodovia situada ao lado no sentido de declive).

\section{$\underline{\text { Pesquisa com ciclistas }}$}

Todos os dez ciclistas que utilizavam a ciclofaixa (100\%) responderam que usavam a bicicleta para trabalhar, estudar, fazer compras, etc. Algumas reclamações frequentes foram: defeitos no pavimento, sinalização deficiente e falta de conservação.

Todos os dez ciclistas que não estavam na ciclovia responderam que estavam utilizando a rodovia para descer porque para tomar a ciclovia no início precisavam cruzar fluxos elevados de veículos motorizados na rotatória.

\section{Pesquisa com moradores da vizinhança}

Todos os dez moradores da vizinhança entrevistados (100\%) responderam que a ciclovia é importante, não somente para os ciclistas como também para os pedestres - que utilizam a ciclovia como passeio. 


\section{Avaliação do segmento}

Os seguintes pontos são relevantes no tocante ao segmento 4:

- Apesar do tráfego de bicicletas no trecho do sistema viário onde se situa a ciclovia ser muito pequeno, a implantação da mesma é aceitável sob a ótica socioeconômica por razões de segurança (os ciclistas não tem que utilizar o acostamento de rodovia onde a velocidade dos veículos é alta). Além disso, também se presta a função de passeio (calçada) para o tráfego de pedestres.

- A implantação da ciclovia tem amplo apoio dos moradores da vizinhança, o que lhe confere viabilidade política.

- A ciclovia somente é utilizada para deslocamentos por motivo de motivo de trabalho, estudo, compras, etc., pois constitui um segmento de ciclovia situado em área não urbanizada e com declive bastante acentuado.

- Não há impacto no trânsito.

- As condições do pavimento, a sinalização e a conservação da ciclovia são insatisfatórias.

\subsection{Caracterização e avaliação do segmento 5}

O segmento 5 consiste de ciclofaixa unidirecional, posicionada do lado direito da rua, está situado na Avenida Vinte e Quatro. A ciclofaixa tem 1,5 metros de largura, extensão de 440 metros e perfil longitudinal com pequena declividade.

Na Figura 5.32 é mostrado o trajeto desse segmento. 


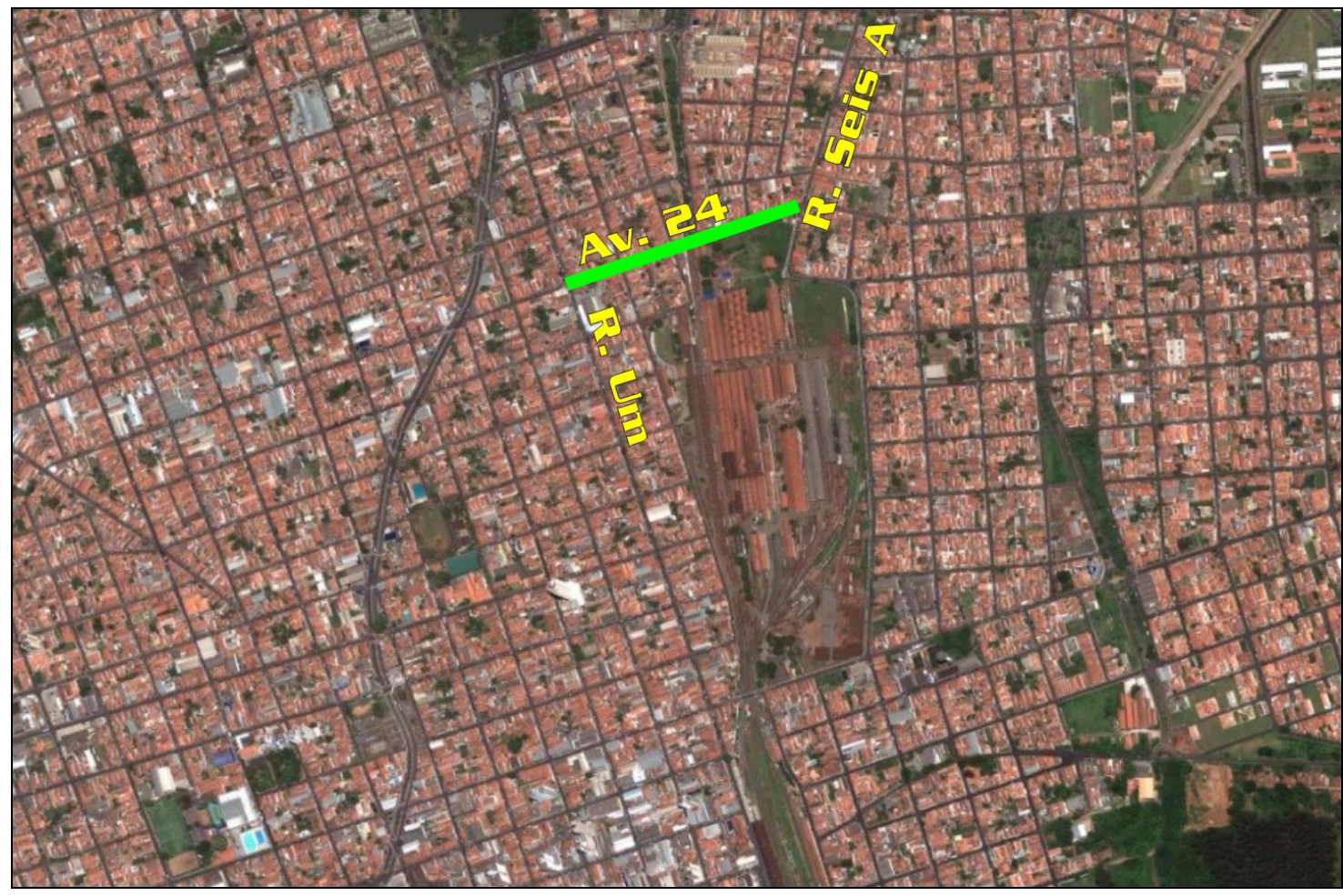

Figura 5.32 - Trajeto do segmento 5.

A seção transversal do sistema viário neste segmento é idêntica a do segmento 1 mostrada na Figura 5.6.

Nas Figuras 5.33 e 5.34 são mostrados diferentes aspectos do segmento 5.

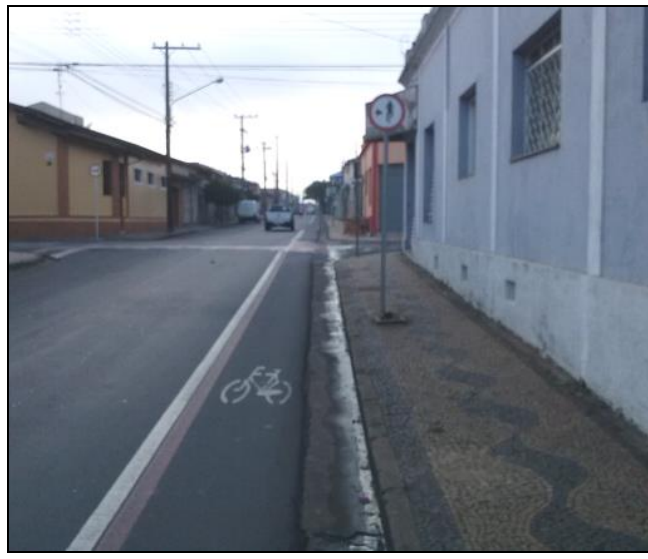

Figura 5.33 - Vista geral da ciclofaixa posicionada ao lado direito da via.

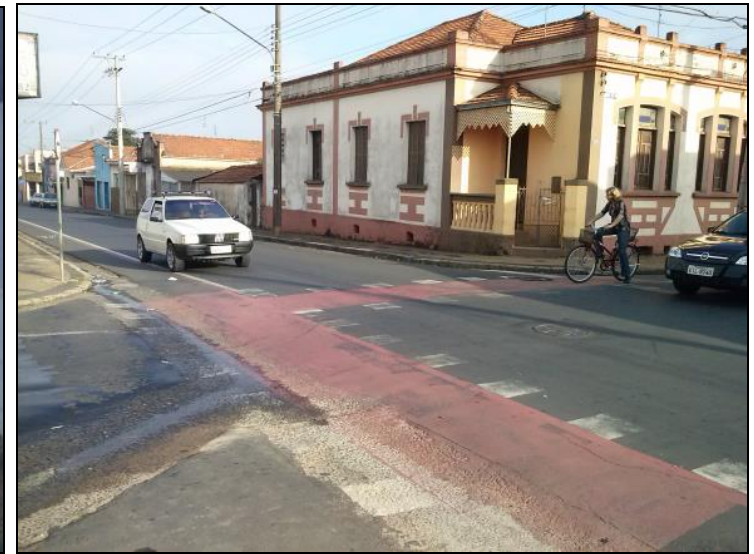

Figura 5.34 - Sinalização em um cruzamento.

A separação do tráfego motorizado é feita com linha vermelha, do lado da ciclofaixa, contigua à linha branca, do lado das faixas de tráfego motorizado. 
A sinalização horizontal é adequada e se encontra em bom estado em muitos trechos, mas desgastada em outros, sobretudo nos cruzamentos com outras ruas. A sinalização vertical é satisfatória na maior parte do percurso e se encontra em estado razoável.

De maneira geral, o pavimento encontra-se em bom estado; somente em alguns poucos locais se observam defeitos.

O estado geral de conservação é satisfatório.

Como a ciclofaixa está situada em uma via preferencial, os ciclistas trafegam sem necessidade de parar nos cruzamentos não semaforizados.

A presença da ciclovia tem impacto bastante negativo no trânsito, praticamente reduzindo as faixas de tráfego da pista de duas para uma, considerando estacionamento de um único lado.

\section{Fluxo de bicicletas}

As contagens do fluxo do tráfego de bicicletas foram realizadas nos períodos de maior movimento em todas as ciclovias: de manhã, das 06:30 às 09:00 h, no meio do dia, das 11:30 às 13:30, e à tarde, das 17:00 às 19:00 h. Na Tabela 5.6 estão relacionados os valores dos fluxos horários encontrados.

Tabela 5.6 - Valores do volume horário (bicicleta/hora).

\begin{tabular}{|c|c|c|c|c|c|c|c|c|}
\hline \multicolumn{3}{|c|}{ Na ciclovia } & \multicolumn{3}{|c|}{ Fora da ciclovia } & \multicolumn{3}{|c|}{ Total } \\
\hline Manhã & $\begin{array}{l}\text { Meio } \\
\text { do dia }\end{array}$ & Tarde & Manhã & $\begin{array}{l}\text { Meio } \\
\text { do dia }\end{array}$ & Tarde & Manhã & $\begin{array}{l}\text { Meio } \\
\text { do dia }\end{array}$ & Tarde \\
\hline 103,6 & 118,0 & 149,0 & 15,2 & 11,0 & 16,0 & 118,8 & 129,0 & 165,0 \\
\hline \multicolumn{3}{|c|}{ Média $=123,5$} & \multicolumn{3}{|c|}{ Média = 14,1 } & \multicolumn{3}{|c|}{ Média $=137,6$} \\
\hline
\end{tabular}

Os valores da Tabela 5.6 permitem inferir que:

- O fluxo de bicicletas é significativo; em média, nos horários de maior movimento, uma bicicleta a cada 21,8 segundos.

- $89,8 \%$ utilizam a ciclovia e $10,2 \%$ não utilizam. 


\section{Pesquisa com ciclistas}

Todos os dez ciclistas que utilizavam a ciclofaixa (100\%) responderam que usavam a bicicleta para trabalhar, estudar, fazer compras, etc. Algumas reclamações frequentes foram: defeitos no pavimento, sinalização deficiente e insegurança nos cruzamentos não semaforizados (os condutores das vias transversais muitas vezes não respeitam a prioridade dos ciclistas que estão na via preferencial).

Todos os dez ciclistas que não estavam na ciclofaixa responderam que iriam fazer conversão à frente.

\section{Pesquisa com moradores da vizinhança}

Dos dez moradores da vizinhança entrevistados, nove (90\%) responderam que a ciclofaixa é importante porque muitas pessoas utilizam bicicletas para se deslocar na cidade.

Um (10\%) disse que ela era desnecessária e que não deveria existir por atrapalhar muito o trânsito.

\section{Avaliação do segmento}

Os seguintes pontos são relevantes no tocante ao segmento 1:

- A implantação da ciclofaixa é viável do ponto de vista socioeconômico uma vez que o investimento é baixo e o tráfego de bicicletas no segmento significativo.

- A implantação da ciclofaixa é viável sob a ótica política, uma vez que a maioria dos moradores da vizinhança aprova a obra.

- A ciclofaixa é utilizada, sobretudo por necessidade: trabalhar, estudar, fazer compras, etc.

- O projeto da ciclofaixa unidirecional é tecnicamente correto; prova disso é que a maioria absoluta dos ciclistas trafega por ela. 
- A presença da ciclovia tem impacto bastante negativo no trânsito, praticamente reduzindo as faixas de tráfego da pista de duas para uma, considerando estacionamento de um único lado.

- As condições do pavimento, a sinalização e a conservação da ciclofaixa não estão satisfatórias.

\subsection{Caracterização e avaliação do segmento 6}

O segmento 6 consiste de ciclofaixa unidirecional, posicionada do lado direito da via em um trecho e do lado esquerdo no outro, está situado nas ruas Um $A$ e Dois. A ciclofaixa tem 1,5 metros de largura, extensão de 2.440 metros e perfil longitudinal com pequena declividade.

Na Figura 5.35 é mostrado o trajeto desse segmento.

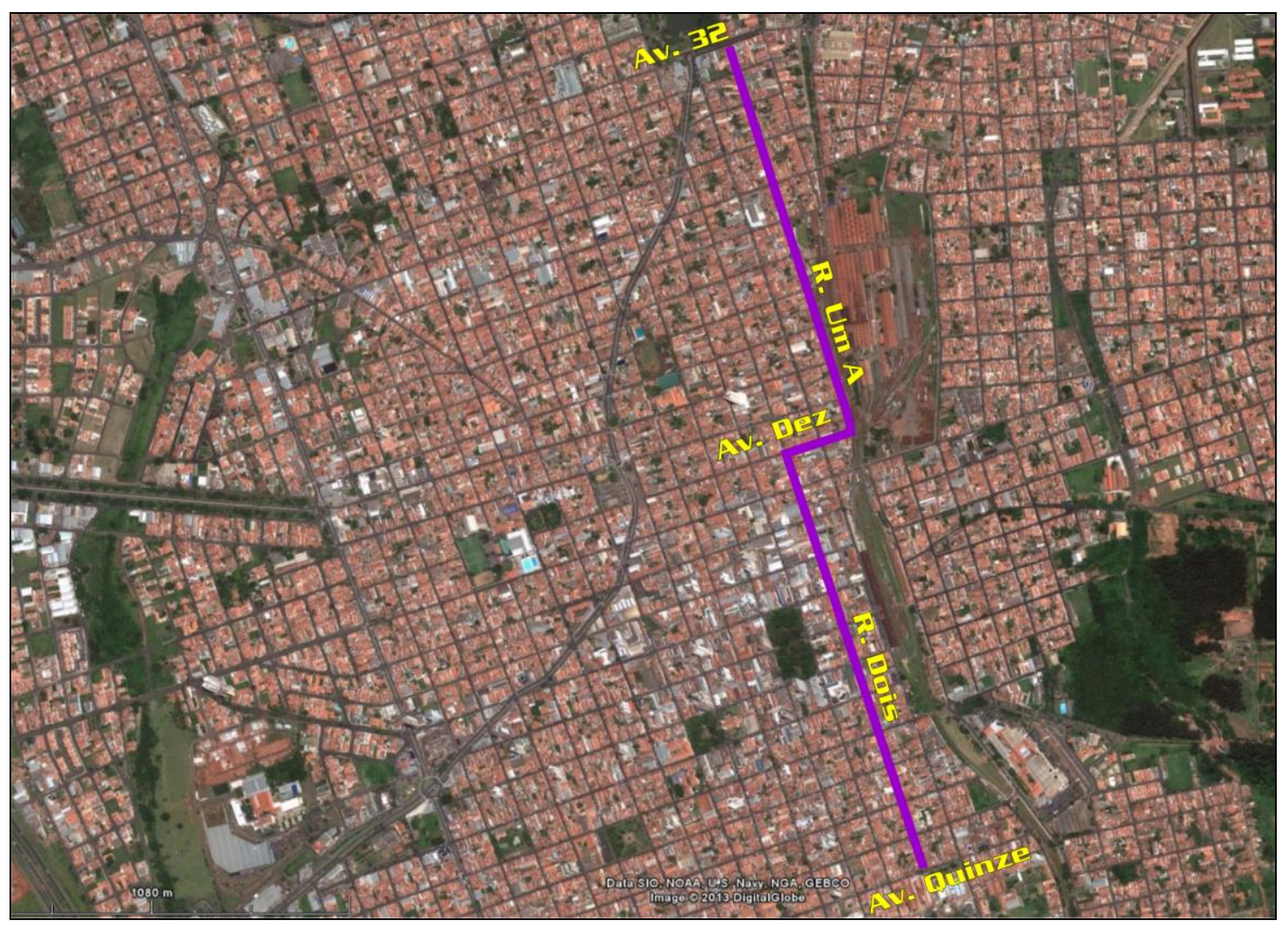

Tabela 5.35 - Trajeto do segmento 6.

A seção transversal do sistema viário neste segmento é idêntica a do segmento 1 mostrada na Figura 5.6. 
Nas Figuras 5.36 a 5.40 são mostrados diferentes aspectos do segmento 6.

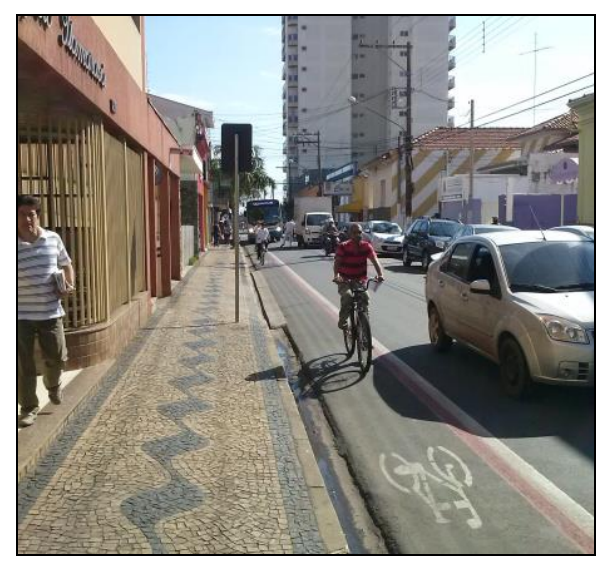

Figura 5.36 - Vista geral da ciclofaixa posicionada ao lado direito da via.

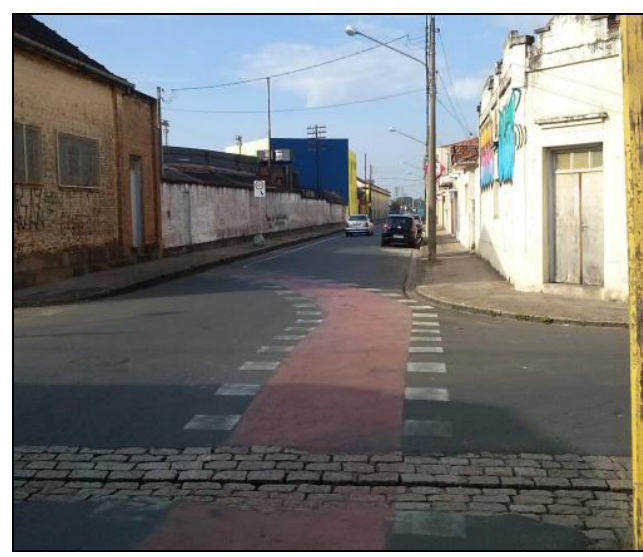

Figura 5.38 - Sinalização no trecho de mudança de lado da ciclofaixa.

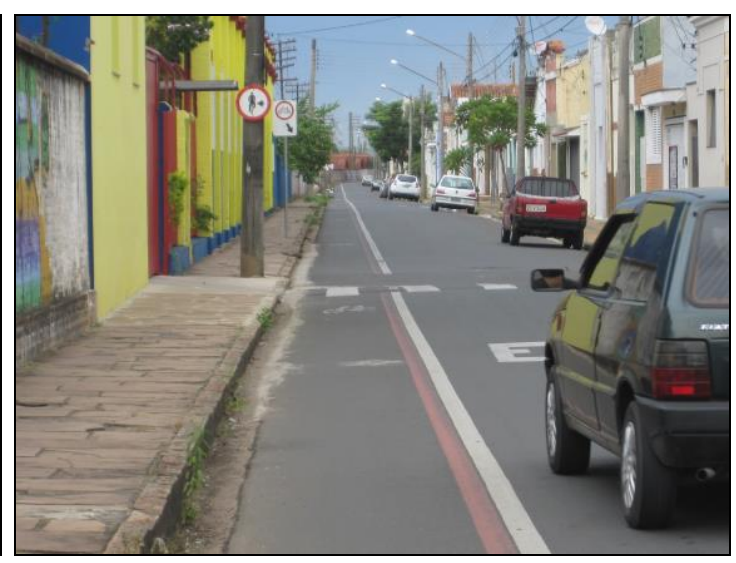

Figura 5.37 - Vista geral da ciclofaixa posicionada ao lado esquerdo da via.

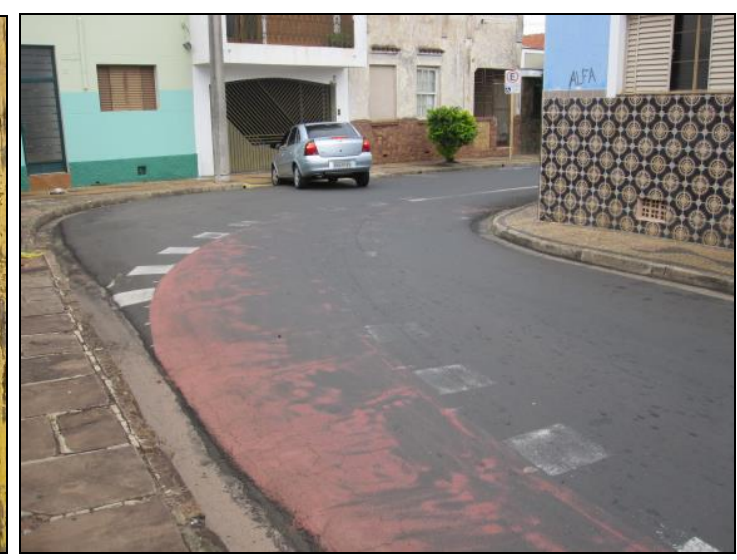

Figura 5.39 - Sinalização da ciclofaixa bastante deteriorada em uma esquina onde ocorre mudança de lado da mesma.

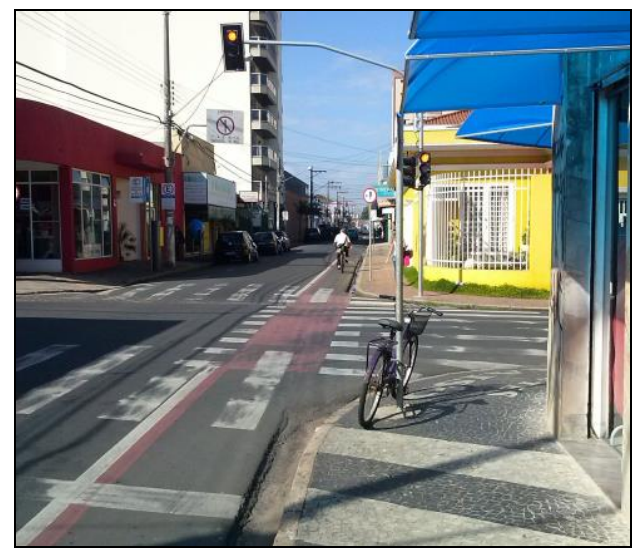

Figura 5.40 - Sinalização típica no cruzamento. 
A separação do tráfego motorizado é feita com linha vermelha, do lado da ciclofaixa, contigua à linha branca, do lado das faixas de tráfego motorizado.

A sinalização horizontal é adequada e se encontra em bom estado em muitos trechos, mas desgastada em outros, sobretudo nos cruzamentos com outras ruas. A sinalização vertical é satisfatória na maior parte do percurso e se encontra em estado razoável.

De maneira geral, o pavimento encontra-se em bom estado; somente em alguns poucos locais se observam defeitos.

O estado geral de conservação é satisfatório.

Como a ciclofaixa está situada em uma via preferencial, os ciclistas trafegam sem necessidade de parar nos cruzamentos não semaforizados.

A presença da ciclovia tem impacto bastante negativo no trânsito, praticamente reduzindo as faixas de tráfego da pista de duas para uma, considerando estacionamento de um único lado.

\section{Fluxo de bicicletas}

As contagens do fluxo do tráfego de bicicletas foram realizadas nos períodos de maior movimento em todas as ciclovias: de manhã, das 06:30 às 09:00 h, no meio do dia, das 11:30 às 13:30, e à tarde, das 17:00 às 19:00 h. Na Tabela 5.7 estão relacionados os valores dos fluxos horários encontrados.

Tabela 5.7 - Valores do volume horário (bicicleta/hora).

\begin{tabular}{ccccccccc}
\hline \multicolumn{3}{c}{ Na ciclovia } & \multicolumn{4}{c}{ Fora da ciclovia } & \multicolumn{3}{c}{ Total } \\
\hline Manhã & $\begin{array}{c}\text { Meio } \\
\text { do dia }\end{array}$ & Tarde & Manhã $\begin{array}{c}\text { Meio } \\
\text { do dia }\end{array}$ & Tarde & Manhã & $\begin{array}{c}\text { Meio } \\
\text { do dia }\end{array}$ & Tarde \\
\hline 174,0 & 129,0 & 49,0 & 3,2 & 3,0 & 3,0 & 177,2 & 132,0 & 52,0 \\
\multicolumn{2}{c}{\begin{tabular}{c} 
Média $=117,3$ \\
\hline
\end{tabular}} & \multicolumn{3}{c}{ Média $=3,1$} & \multicolumn{3}{c}{ Média $=120,4$} & \\
\hline
\end{tabular}

Os valores da Tabela 5.7 permitem inferir que:

- O número de ciclistas é significativo; em média, nos horários de maior movimento, uma bicicleta a cada 32 segundos. 
- $97,4 \%$ utilizam a ciclovia e 2,6\% não utilizam.

\section{Pesquisa com ciclistas}

Todos os dez ciclistas que utilizavam a ciclofaixa (100\%) responderam que usavam a bicicleta para trabalhar, estudar, fazer compras, etc. Algumas reclamações frequentes foram: defeitos no pavimento, sinalização deficiente e insegurança nos cruzamentos não semaforizados (os condutores das vias transversais muitas vezes não respeitam a prioridade dos ciclistas que estão na via preferencial).

Todos os dez ciclistas que não estavam na ciclofaixa responderam que realizariam a conversão à frente.

\section{$\underline{\text { Pesquisa com moradores da vizinhança }}$}

Dos dez moradores da vizinhança entrevistados, cinco $(50 \%)$ responderam que a ciclofaixa é importante porque muitas pessoas utilizam bicicletas para se deslocar na cidade.

Cinco (50\%) disseram que ela era desnecessária e que não deveria existir por atrapalhar muito o trânsito.

\section{Avaliação do segmento}

Os seguintes pontos são relevantes no tocante ao segmento 1:

- A implantação da ciclofaixa é viável do ponto de vista socioeconômico uma vez que o investimento é baixo e o tráfego de bicicletas no segmento significativo.

- A implantação da ciclofaixa é viável sob a ótica política, uma vez que a maioria dos moradores da vizinhança aprova a obra.

- A ciclofaixa é utilizada, sobretudo por necessidade: trabalhar, estudar, fazer compras, etc.

- O projeto da ciclofaixa unidirecional é tecnicamente correto; prova disso é que a maioria absoluta dos ciclistas trafega por ela. 
- A presença da ciclovia tem impacto bastante negativo no trânsito, praticamente reduzindo as faixas de tráfego da pista de duas para uma, considerando estacionamento de um único lado.

- As condições do pavimento, a sinalização e a conservação da ciclofaixa não estão satisfatórias.

\subsection{Caracterização e avaliação do segmento 7}

O segmento 2 consiste de ciclofaixa unidirecional posicionada na maior parte do trajeto do lado direito da via e em um pequeno trecho, junto ao terminal central de ônibus, do lado esquerdo, está situado na Rua Um. A ciclofaixa tem 1,5 metros de largura, extensão de 1.740 metros e perfil longitudinal com pequena declividade.

Na Figura 5.41 é mostrado o trajeto desse segmento.

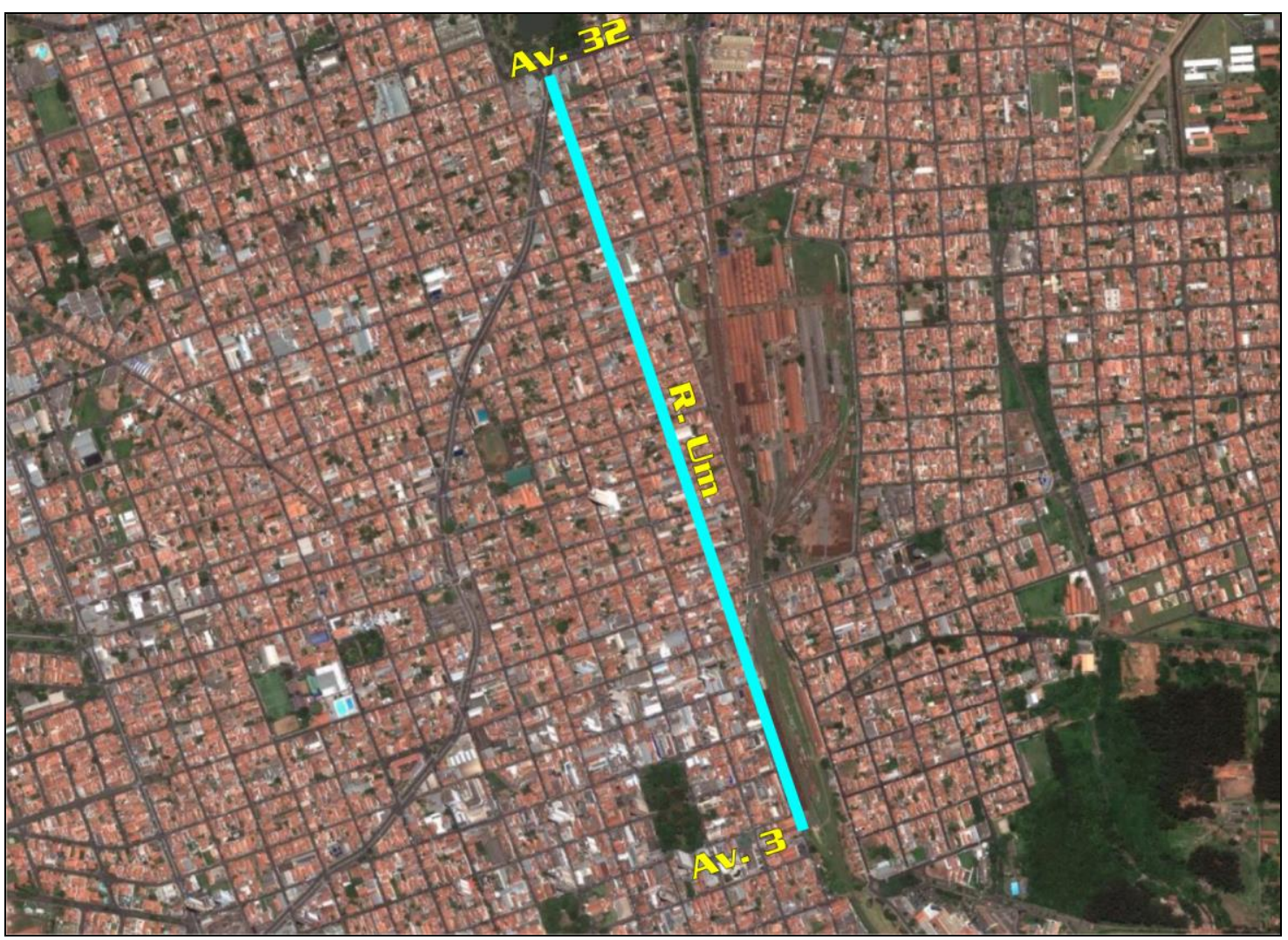

Figura 5.41 - Trajeto do segmento 7. 
A seção transversal do sistema viário neste segmento é idêntica a do segmento 1 mostrada na Figura 5.6.

Nas Figuras 5.42 a 5.45 são mostrados diferentes aspectos do segmento 7.

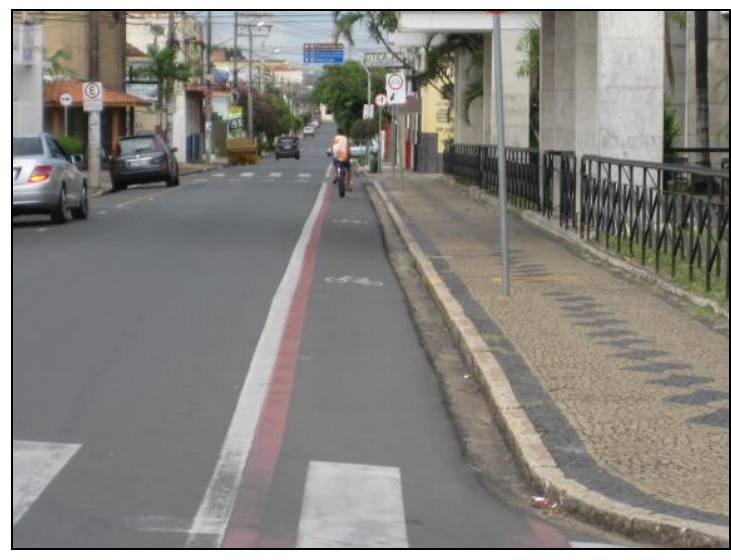

Figura 5.42 - Vista geral da ciclofaixa posicionada ao lado direito da via.

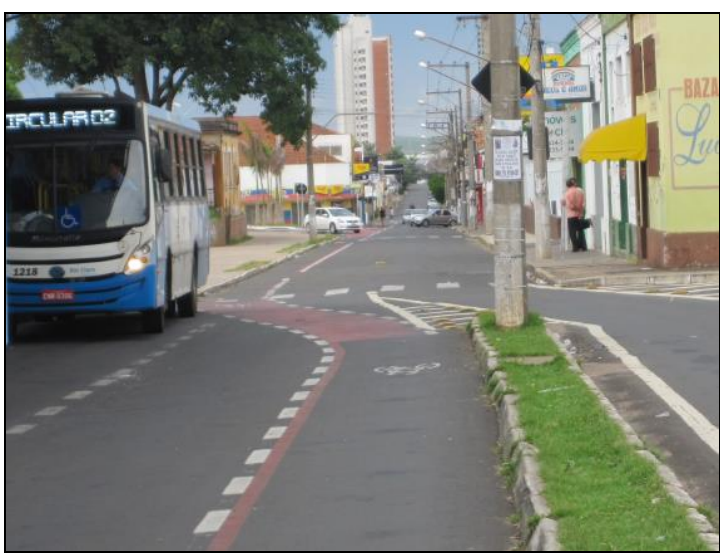

Figura 5.44 - Sinalização no trecho de mudança de lado da ciclofaixa.

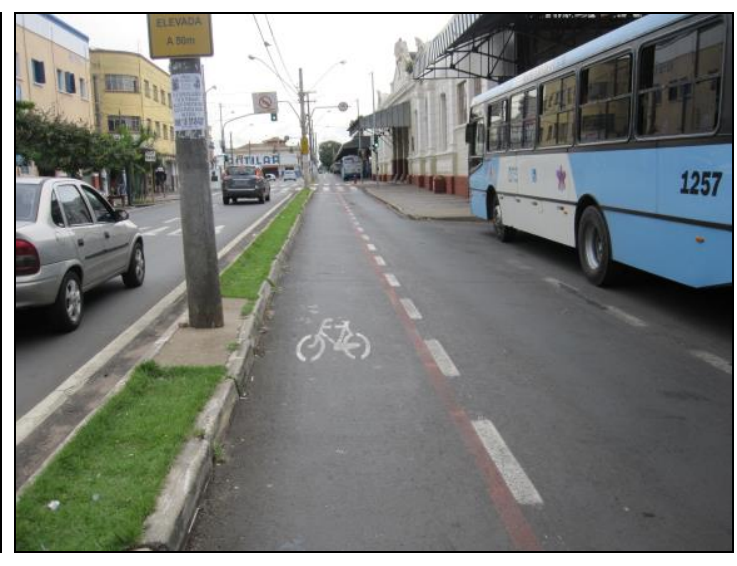

Figura 5.43 - Vista geral da ciclofaixa posicionada ao lado esquerdo da via.

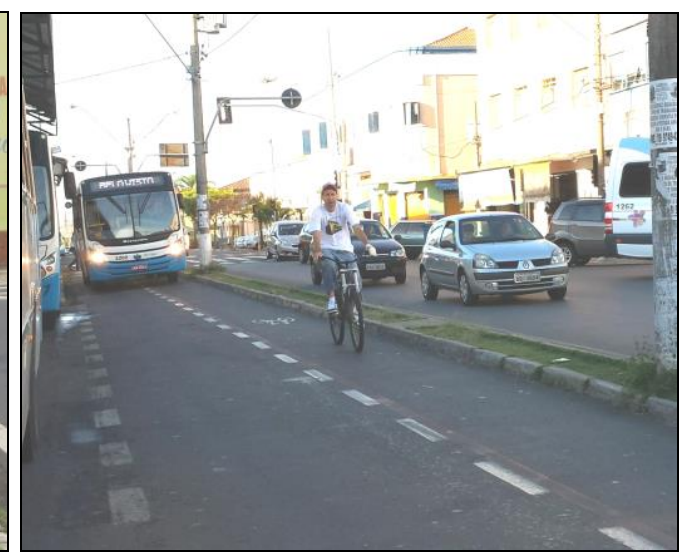

Figura 5.45 - Ônibus circulando sobre a ciclofaixa junto ao terminal.

A separação do tráfego motorizado é feita com linha vermelha, do lado da ciclofaixa, contigua à linha branca, do lado das faixas de tráfego motorizado.

A sinalização horizontal é adequada e se encontra em bom estado em muitos trechos, mas desgastada em outros, sobretudo nos cruzamentos com outras ruas. A sinalização vertical é satisfatória na maior parte do percurso e se encontra em estado razoável. 
De maneira geral, o pavimento encontra-se em bom estado; somente em alguns poucos locais se observam defeitos.

O estado geral de conservação é satisfatório.

Como a ciclofaixa está situada em uma via preferencial, os ciclistas trafegam sem necessidade de parar nos cruzamentos não semaforizados.

A presença da ciclovia tem impacto bastante negativo no trânsito, praticamente reduzindo as faixas de tráfego da pista de duas para uma, considerando estacionamento de um único lado.

\section{Fluxo de bicicletas}

As contagens do fluxo do tráfego de bicicletas foram realizadas nos períodos de maior movimento em todas as ciclovias: de manhã, das 06:30 às 09:00 h, no meio do dia, das 11:30 às 13:30, e à tarde, das 17:00 às 19:00 h. Na Tabela 5.8 estão relacionados os valores dos fluxos horários encontrados.

Tabela 5.8 - Valores do volume horário (bicicleta/hora).

\begin{tabular}{|c|c|c|c|c|c|c|c|c|}
\hline \multicolumn{3}{|c|}{$\mathrm{Na}$ ciclovia } & \multicolumn{3}{|c|}{ Fora da ciclovia } & \multicolumn{3}{|c|}{ Total } \\
\hline Manhã & $\begin{array}{l}\text { Meio } \\
\text { do dia }\end{array}$ & Tarde & Manhã & $\begin{array}{c}\text { Meio } \\
\text { do dia }\end{array}$ & Tarde & Manhã & $\begin{array}{c}\text { Meio } \\
\text { do dia }\end{array}$ & Tarde \\
\hline 38,0 & 57,0 & 42,5 & 8,4 & 20,0 & 16,5 & 46,4 & 77,0 & 59,0 \\
\hline \multicolumn{3}{|c|}{ Média $=45,8$} & \multicolumn{3}{|c|}{ Média = 15,0 } & \multicolumn{3}{|c|}{ Média $=60,8$} \\
\hline
\end{tabular}

Os valores da Tabela 5.8 permitem inferir que:

- O fluxo de bicicletas é razoável; em média, nos horários de maior movimento, uma bicicleta a cada 59 segundos.

- $75,3 \%$ utilizam a ciclovia e $24,7 \%$ não utilizam.

\section{$\underline{\text { Pesquisa com ciclistas }}$}

Todos os dez ciclistas que utilizavam a ciclofaixa (100\%) responderam que usavam a bicicleta para trabalhar, estudar, fazer compras, etc. Algumas reclamações frequentes foram: defeitos no pavimento, sinalização deficiente e 
insegurança nos cruzamentos não semaforizados (os condutores das vias transversais muitas vezes não respeitam a prioridade dos ciclistas que estão na via preferencial).

Todos os dez ciclistas que não estavam na ciclofaixa responderam que realizariam a conversão à frente.

\section{Pesquisa com moradores da vizinhança}

Dos dez moradores da vizinhança entrevistados, seis $(60 \%)$ responderam que a ciclofaixa é importante porque muitas pessoas utilizam bicicletas para se deslocar na cidade.

Quatro (40\%) disseram que ela era desnecessária e que não deveria existir por atrapalhar muito o trânsito.

\section{Avaliação do segmento}

Os seguintes pontos são relevantes no tocante ao segmento 1:

- A implantação da ciclofaixa é viável do ponto de vista socioeconômico uma vez que o investimento é baixo e o tráfego de bicicletas no segmento significativo.

- A implantação da ciclofaixa é viável sob a ótica política, uma vez que a maioria dos moradores da vizinhança aprova a obra.

- A ciclofaixa é utilizada, sobretudo por necessidade: trabalhar, estudar, fazer compras, etc.

- O projeto da ciclofaixa unidirecional é tecnicamente correto; prova disso é que a maioria absoluta dos ciclistas trafega por ela.

- A presença da ciclovia tem impacto bastante negativo no trânsito, praticamente reduzindo as faixas de tráfego da pista de duas para uma, considerando estacionamento de um único lado.

- As condições do pavimento, a sinalização e a conservação da ciclofaixa não estão satisfatórias. 


\subsection{Avaliação geral do sistema cicloviário de Rio Claro}

Os seguintes índices globais são verificados em Rio Claro:

- A implantação dos segmentos 1, 4, 5, 6 e 7 é justificável do ponto de vista socioeconômico, uma vez que o tráfego de bicicletas em todos eles é grande; e, também, sob a ótica política, pois a maioria dos moradores da vizinhança aprova a ciclofaixa.

- A implantação do segmento 3 em um canteiro central amplos de uma via, é plenamente justificável do ponto de vista socioeconômico, uma vez que tem uma grande utilização como espaço para o tráfego de ciclistas por motivo de trabalho, estudo e compras e, ao mesmo tempo, com espaço para a prática de exercícios e de lazer. Também o é sob a ótica política, pois tem a aprovação da maioria absoluta da população.

- Fluxo de bicicletas constitui espaço para a prática de exercícios e lazer, e também sob a ótica política, pois a maioria dos moradores da vizinhança aprova a ciclovia.

- Ainda que o fluxo de bicicletas seja muito baixo, a implantação do segmento 6 é justificável do ponto de vista socioeconômico, pois proporciona maior segurança e comodidade para os ciclistas uma vez que evita que tenham que utilizar o acostamento de trecho rodoviário e subir rampa íngreme em um dos sentidos de percurso.

- A implantação da ciclovia do segmento 6 é questionável do ponto de vista socioeconômico, uma vez que o tráfego de bicicletas é muito pequeno, e, também sob a ótica política, pois a maioria dos moradores da vizinhança não aprova a ciclovia. No tocante a ciclofaixa, a situação é ainda pior, pois como se situa em um trecho em rampa acentuada, a maioria absoluta dos ciclistas entende como mais seguro empurrar as suas bicicletas na calçada; e a maioria absoluta da população rejeita a mesma.

- Excetuando o segmento 6, todos os outros apresentam problemas técnicos graves que levam os ciclistas a trafegar do lado direito das pistas comuns de 
tráfego, não utilizando a ciclovia/ciclofaixa por razões de segurança e praticidade.

- O segmento 1 tem o seu desempenho prejudicado pela existência de rampa acentuada em grande parte da sua extensão.

- De maneira geral, nos segmentos 1,2,3,5 e 7 as condições do pavimento, a sinalização e a conservação são satisfatórias. Nos segmentos 4 e 6, não.

- A implantação dos segmentos 1,5 e 6 é questionável do ponto de vista socioeconômico, uma vez que o tráfego de bicicletas em todos eles é muito pequeno, e, também sob a ótica política, pois a maioria dos moradores da vizinhança não aprova a ciclovia/ciclofaixa.

- A implantação dos três segmentos é questionável do ponto de vista socioeconômico, uma vez que o tráfego de bicicletas em todos eles é muito pequeno.

- A implantação dos três segmentos é questionável sob a ótica política, pois a maioria dos moradores da vizinhança não aprova a ciclovia/ciclofaixa.

- Os segmentos 1 e 2 apresentam problemas técnicos graves que levam os ciclistas a trafegar do lado direito das pistas comuns de tráfego, não utilizando a ciclovia/ciclofaixa por razões de segurança e praticidade.

- O segmento 1 tem o seu desempenho prejudicado pela existência de rampa acentuada em grande parte da sua extensão.

- Há trechos dos segmentos 1 e 2 onde a existência da ciclovia traz prejuízo para o trânsito geral.

- De maneira geral, as condições do pavimento, a sinalização e a conservação dos três segmentos são insatisfatórias.

No que concerne a índices globais, Rio Claro apresenta os seguintes valores:

- População = 196.821 habitantes 
- Extensão do sistema cicloviário $=18.020$ metros de ciclovia/ciclofaixa (considerando em separado cada sentido de fluxo).

- Soma dos valores médios dos fluxos de bicicletas nos períodos de maior movimento nas vias onde se localizam os segmentos cicloviários $=680,00$ bicicletas por hora.

- Relação entre a extensão do sistema cicloviário e a população $=91,56$ metros de ciclovia/ciclofaixa por mil habitantes.

- Relação entre a soma dos fluxos de bicicletas e a população $=345,49$ bicicletas por hora por cem mil habitantes.

- Relação entre a soma dos fluxos de bicicletas e a extensão do sistema cicloviário $=37,74$ bicicletas por hora por $\mathrm{km}$ de ciclovia/ciclofaixa.

Esses valores quando comparados com os das outras cidades estudadas (Araraquara e São Carlos) permite fazer as seguintes inferências:

- Rio Claro tem a maior extensão do sistema cicloviário: 2,71 vezes mais que Araraquara e 1,18 vezes mais que São Carlos.

- Rio Claro tem a maior soma dos fluxos de bicicletas: 11,11 vezes mais que Araraquara e 6,30 vezes mais que São Carlos.

- Rio Claro tem a maior relação entre a extensão do sistema viário e a população: 3,05 vezes mais que Araraquara e 1,41 vezes mais que São Carlos.

- Rio Claro tem a maior relação entre a soma dos fluxos de bicicletas e a população: 12,54 mais que Araraquara e 7,57 vezes mais que São Carlos.

- Rio Claro tem a maior relação entre a soma dos fluxos de bicicletas e a extensão do sistema cicloviário: 4,10 vezes mais que Araraquara e 5,35 vezes mais que São Carlos. 


\section{6- EPÍLOGO}

Neste último capítulo são apresentados alguns pontos relevantes no contexto do trabalho.

\subsection{Sobre as diferenças no uso do modo bicicleta}

$\mathrm{Na}$ Tabela 6.1 estão reproduzidos alguns parâmetros relacionados com o uso da bicicleta e com o nível de desenvolvimento econômico-social dos três municípios estudados.

Tabela 6.1 - Índices associados aos três municípios.

\begin{tabular}{cccc}
\hline Parâmetro & Araraquara & São Carlos & Rio Claro \\
\hline $\begin{array}{c}\text { Soma dos fluxos de bicicletas } \\
\text { nos segmentos per capita } \\
\text { (bicicletas/h/100.000hab) }\end{array}$ & 27,56 & 45,63 & 345,49 \\
$\begin{array}{c}\text { Extensão do sistema cicloviário } \\
\text { (metros) }\end{array}$ & 6.660 & 15.300 & 18.020 \\
$\begin{array}{c}\text { Extensão do sistema cicloviário } \\
\text { per capita (metros/1.000hab) } \\
\text { Índice de desenvolvimento } \\
\text { humano municipal (2010) }\end{array}$ & 30,00 & 64,71 & 91,56 \\
$\quad$ Renda per capita (2010) & 0,815 & 0,805 & 0,803 \\
(R\$mês) & 891,74 & 923,62 & 840,39 \\
Índice de Gini* $(2010)$ & 0,5039 & 0,4986 & 0,5081 \\
\hline
\end{tabular}

*Índice de Gini da renda domiciliar per capita (quanto mais próximo de zero maior a distribuição da renda; quanto mais próximo de 1 menor a distribuição da renda).

Os valores do parâmetro denominado "soma dos fluxos de bicicletas nos segmentos per capita" mostram que há diferenças significativas no uso do 
modal bicicleta nas três cidades analisadas. Os valores relativos são os seguintes: Araraquara =1, São Carlos = 1,66 e Rio Claro = 12,54.

O uso muito maior do modal bicicleta em Rio Claro deve-se ao conjunto dos seguintes fatores: a preponderância de vias com baixa declividade na maior parte da área urbana, a qualidade insatisfatória do transporte coletivo nas últimas décadas, a renda média inferior da população, a muito ligeiramente maior concentração de renda e a maior influência da cultura européia (alemã e italiana) na colonização da cidade - esses países têm grande tradição no uso da bicicleta.

O maior valor do parâmetro "soma dos fluxos de bicicletas nos segmentos per capita" em São Carlos, quando comparado com Araraquara, deve-se tão somente ao fato de São Carlos ter um maior número de ciclovias/ciclofaixas.

Os três principais fatores inibidores do uso do modal bicicleta em São Carlos são: a topografia acidentada (em grande parte da área urbana as vias tem rampas acentuadas), o maior nível de desenvolvimento socioeconômico e a ausência de tradição/cultura do uso da bicicleta. Em Araraquara, são: a boa qualidade do transporte coletivo nas últimas décadas, o maior nível de desenvolvimento socioeconômico e a ausência de tradição/cultura do uso da bicicleta.

\subsection{Sobre os tipos de segmentos cicloviários e a visão da população}

No estudo das três cidades foram identificados quatro tipos distintos de segmentos cicloviários: ciclovia bidirecional em canteiro central de via, ciclovia bidirecional ao lado de rodovia, ciclofaixa/ciclovia bidirecional posicionada do lado direito de via com sentido único de tráfego e ciclofaixa/ciclovia unidirecional posicionada do lado direito/esquerdo com o mesmo sentido de tráfego da via.

A ciclovia bidirecional em canteiro central de via tem a intenção de servir para deslocamentos por "necessidade" e, também, para a prática de exercícios e de lazer. Na sua maioria, no entanto, os ciclistas que se deslocam por 
"necessidade" optam por utilizar as vias do tráfego geral situadas ao lado, se posicionando comumente do lado direito, em razão da maior segurança e praticidade (não precisam parar nos cruzamentos, o que em geral acontece, e não é necessitam "cortar" fluxos do tráfego geral para entrar e sair da ciclovia fato que é atenuado quando cresce o percurso feito na ciclovia). Este tipo de segmento cicloviário tem a aprovação da maioria da população por ser visto, principalmente, como um espaço para a prática de exercícios e lazer.

A ciclovia bidirecional posicionada ao lado de rodovia tem o propósito de proporcionar maior segurança para ciclistas - e para pedestres, pois esses, em geral, também utilizam a via para transitar -, evitando o trânsito no acostamento da rodovia. Nos casos em que o movimento é razoável e o efeito segurança sensível, goza da aprovação da maioria da população. Nos casos em que isso não ocorre, não tem a aprovação da população.

A ciclofaixa/ciclovia bidirecional posicionada do lado direito junto à guia de uma via de sentido único tem a intenção principal de servir para deslocamentos por "necessidade". No entanto, na sua maioria, os ciclistas que se deslocam no sentido contrário do fluxo da via onde se localiza a ciclofaixa/ciclovia optam por utilizar a direita da via paralela próxima que tem o mesmo sentido de fluxo em razão da maior segurança e praticidade (não precisam parar nos cruzamentos - o que em geral acontece -, não trafegam no contra fluxo e não precisam "cortar" fluxos do tráfego geral para entrar e sair da ciclofaixa/ciclovia - fato que é atenuado quando cresce o percurso na ciclovia). Este tipo de segmento cicloviário não tem a aprovação da maioria da população; a minoria que aprova o faz por ver na ciclofaixa/ciclovia um espaço para a prática de exercícios e de lazer.

A ciclofaixa/ciclovia unidirecional posicionada do lado direito junto à guia de uma via de sentido único tem a intenção principal de servir para deslocamentos por "necessidade". Tem total aceitação por parte dos ciclistas, pelos seguintes motivos: não precisam parar nos cruzamentos quando nas vias preferenciais para isso é fundamental uma sinalização adequada -, transitam no mesmo sentido do fluxo de tráfego e não precisam "cortar" fluxos do tráfego geral para 
entrar e sair da ciclofaixa/ciclovia. Este tipo de segmento cicloviário tem a aprovação da população quando o fluxo de bicicletas é alto. Parte da população aponta, no entanto, como um sério problema o prejuízo para o trânsito de veículos. Quando a ciclofaixa/ciclovia está posicionada do lado esquerdo junto à guia, há, a princípio, uma menor segurança em relação ao posicionamento do lado direito.

\subsection{Sobre o impacto da bicicleta na fluidez do trânsito}

Quando a ciclofaixa/ciclovia ocupa parte do espaço da pista há redução da largura da via destinada ao tráfego geral e, por consequência, prejuízo para o trânsito de fluidez e/ou estacionamento. O prejuízo depende da largura original destinada ao tráfego geral e da largura da ciclofaixa/ciclovia.

No caso comum de vias com largura entre 7,50 e 8,50 metros, as seguintes alternativas são factíveis: três faixas de tráfego, duas faixas de tráfego e uma de estacionamento e uma faixa de tráfego e duas de estacionamento. Com a presença de ciclovia unidirecional com largura de 1,50 metros, é perdida uma faixa de tráfego ou de estacionamento.

Quando não há demarcação de ciclofaixa/ciclovia na via, o prejuízo aos carros, caminhões e ônibus se limita a trafegar atrás das bicicletas com velocidade reduzida até poder ultrapassá-las.

Outro impacto negativo no trânsito do tráfego de bicicletas ocorre nos cruzamentos com vias secundárias não semaforizados. A passagem de qualquer veículo, incluindo a bicicleta, impede os veículos da via secundária de entrarem na interseção. Assim, se o número de bicicletas é elevado passa a ser necessário semaforizar os cruzamentos mais movimentados. Isso também vale para o caso da travessia de pedestres.

Nesse sentido, cabe refletir sobre o seguinte exemplo ilustrativo. Em uma via onde passam 10 ônibus por hora (um a cada 6 minutos) com lotação média de 50 passageiros, se todos os passageiros passassem a utilizar bicicleta o fluxo horário aumentaria de 10 veículos (ônibus) para 500 veículos (bicicletas), o que 
certamente exigiria a colocação de semáforos em praticamente todos os cruzamentos com vias secundárias.

\subsection{Sobre a segurança no uso da bicicleta}

De acordo com as estatísticas, nos países desenvolvidos o risco de se ferir ou morrer utilizando a bicicleta é 6 a 10 vezes maior do que transitando de carro e 20 a 70 vezes maior do que de ônibus. Ferraz et al (2012)

No Brasil, não há estatísticas sobre isso, mas o fato é que nas cidades é muito raro uma pessoa viajando de ônibus morrer ou se ferir gravemente em um acidente de trânsito. Transitando de carro, o risco ainda é bastante pequeno. De motocicleta, o risco aumenta consideravelmente - Ferraz et al (2012) mencionam um risco de morrer aproximadamente 30 vezes maior. Dados preliminares relativos ao ano de 2012 verificados na cidade de Araraquara mostram que utilizando bicicleta o risco de morrer é cerca de 25 vezes maior em relação ao carro.

O fato é que a questão da segurança constitui um dos principais fatores inibidores do uso do modal bicicleta no país. 
Avaliação dos sistemas cicloviários de três cidades do interior do estado de São Paulo 


\section{REFERÊNCIAS BIBLIOGRÁFICAS}

AASHTO. Guide for the Planning, Design, and Operation of Bicycle Facilities. American Association of State Highway and Transportation Officials. $1^{\underline{a}}$ ed. Washington, D.C., 2010.

ASSOCIAÇÃO NACIONAL DE TRANSPORTES PÚBLICOS - ANTP. Disponível em <http://www.antp.gov.br> Acesso em: 14 jun. 2013.

ASSOCIAÇÃO BRASILEIRA DOS FABRICANTES DE MOTOCICLETAS. CICLOMOTORES, MOTONETAS, BICICLETAS E SIMILARES - ABRACICLO. Frota estimada de bicicletas em 2012. Disponível em <http://www.abraciclo.com.br>. Acesso em: 12 ago. 2013.

BICYCLE RESOURCES. City of Portland Transportation. Bicycle Resources \& Organizations. 2000. Disponível em http://www.portlandoregon.gov/bps/article/336131. Acesso em: 07 mai. 2013.

CROW. Design Manual for Bicycle Traffic. Galvanistraast, 2007.

DEPARTAMENTO NACIONAL DE INFRAESTRUTURA EM TRANSPORTES - DNIT (2011). Manual de Projeto Geométrico de Travessias Urbanas. Rio de Janeiro, 2010. 392p. (IPR. Publ., 740).

DEPARTAMENTO NACIONAL DE TRÂNSITO DENATRAN (2013). Frota Municipal 2013. Disponível em <http://www.denatran.gov.br/frota.htm>. Acesso em: 12 ago. 2013.

ELVIK, R.; VAA, T. The Handbook of Road Safety Measures. Editora Elsevier, 2004. 
FERRAZ, A. C. P.; RAIA JR, A. A.; BEZERRA, B.; BASTOS, J.T.; RODRIGUES, K. Segurança Viária. $1^{\underline{a}}$ ed. São Carlos: Rima, 2004.

FUNDAÇÃO SISTEMA ESTADUAL DE ANÁLISE DE DADOS - SEADE (2013). Disponível em <http://seade.gov.br> Acesso em: 19 mai. 2013.

GEIPOT - Empresa Brasileira de Planejamento de Transportes. Planejamento cicloviário: Diagnóstico Nacional. Brasília: 2001a.

GEIPOT- Empresa brasileira de planejamento de transportes. Manual de planejamento cicloviário. - 3. ed., ver. e amp. - Brasília: 2001b.

GOMES, P. C. da C. A condição urbana: ensaios de geopolítica da cidade. Rio de Janeiro: Bertrad Brasil, 2002.

GONDIM, M. F. Cadernos de Desenho: Ciclovias. Editoração Eletrônica, 2010.

GUIMARÃES, C. A. B. Planejamento cicloviário em cidades de pequeno e médio porte. São Carlos: Universidade de São Paulo, 1989.

INSTITUTO BRASILEIRO DE GEOGRAFIA E ESTATÍSTICA - IBGE (2013). Cidades 2013. Disponível em: <http://www.ibpsnet.com.br>. Acesso em: 14 jun. 2013.

INSTITUTO BRASILEIRO DE PESQUISA SOCIAL. Disponível em <http://www.antp.gov.br> Acesso em: 14 jun. 2013.

INSTITUTO DE ENERGIA E MEIO AMBIENTE - IEMA (2010). Disponível em: <http://www.energiaeambiente.org.br>. Acesso em: 08 jul. 2013.

LIMA, R. S. Expansão Urbana e Acessibilidade - 0 caso das cidades médias brasileiras. 1998. 80 f. Dissertação (Mestrado em Engenharia de Transportes) Escola de Engenharia de São Carlos, Universidade de São Paulo, São Carlos, 1998. 
KOORNSTRA, M.K. Transport Safety Performance in the EU. Brussels, European Transport Safety Council, 2003. <http://www.etsc.be/rep.htm>.

MINISTÉRIO DAS CIDADES. Plano de Mobilidade por Bicicleta nas Cidades. Coleção Bicicleta Brasil, Caderno 1, Secretaria Nacional de Transporte e da Mobilidade Urbana, Brasília, 2007.

MINISTÉRIO DAS CIDADES. Política Nacional de Mobilidade Urbana Sustentável. Cadernos MCidades Mobilidade, 2004.

MIRANDA, A. C. M.; CITADIN, L. L.; ALVES, E. V. A importância das ciclofaixas na inserção da bicicleta no trânsito urbano das grandes cidades. 2009.

MOBILIZE, Estudo Mobilize 2011. Mobilidade Urbana Sustentável. Diagnostico da mobilidade urbana sustentável em capitais brasileiras. Disponível em <http://www.mobilize.org.br> Acesso em: 03 ago. 2013.

PEZZUTO, C. C. Fatores que influenciam o uso da bicicleta. Dissertação (Mestrado em Engenharia Urbana). Universidade Federal de São Carlos, São Carlos, 2002.

PIRES, C. C. Potencialidades cicloviárias no Plano Piloto. Dissertação (Mestrado). Universidade de Brasília. Brasília, 2008.

PORTAL MOBILIZE BRASIL. MOBILIDADE URBANA SUSTENTÁVEL. Disponível em: <http://www.mobilize.org.br>. Acesso em: 02 ago. 2013.

PREFEITURA MUNICIPAL DE ARARAQUARA. Disponível em <http://araraquara.sp.gov.br>. Acesso em: 07 jun. 2013.

PREFEITURA MUNICIPAL DE RIO CLARO. Disponível em <http://rioclaro.sp.gov.br>. Acesso em: 10 jun. 2013.

PREFEITURA MUNICIPAL DE SÃO CARLOS. Disponível em <http://saocarlos.sp.gov.br> Acesso em: 10 jun. 2013. 
RICCARDI, J. C. R. Ciclovias e Ciclofaixas: Critérios para localização e implantação. Monografia (Graduação em Engenharia Civil) - Escola de Engenharia da Universidade Federal do Rio Grande do Sul, Universidade Federal do Rio Grande do Sul, Porto Alegre, 2010.

SHAFIZADEH, K. e NIEMEIER, D. Bicycle journey-to-work: travel behavior characteristics and spatial attributes. Transportation Research Record 1578, 1997. pp. 84-90.

TERAMOTO, T. T. Planejamento de transporte cicloviário urbano: Organização da circulação. Dissertação (Mestrado em Engenharia Urbana). Universidade Federal de São Carlos, São Carlos, 2008.

YUASSA, V. N. Impacto da hierarquia viária orientada para o automóvel no nível de serviço de modos não motorizados. Dissertação (Mestrado em Engenharia de Transportes) - Escola de Engenharia de São Carlos, Universidade de São Paulo, São Carlos, 2008. 


\section{APÊNDICES}

Segue os modelos de formulários utilizados na pesquisa. 


\section{QUESTIONÁRIO PARA CICLISTAS QUE NÃO UTILIZAM A \\ CICLOVIA/CICLOFAIXA}

Entrevistador:

Número da Entrevista:

\section{Características do entrevistado}

Sexo:

Faixa etária:

( ) Masculino

( ) Jovem

( ) Feminino

( ) Adulto

( ) Idoso

1. Por que você prefere utilizar a via normal e não a ciclovia/ciclofaixa?

$\square$ Por que é inseguro

$\square$ Por que o pavimento é ruim

$\square$ Por que é complicado para atravessar os cruzamentos

$\square$ Por que é muito estreita

$\square$ Outra razão. Qual? 


\section{QUESTIONÁRIO PARA CICLISTAS QUE UTILIZAM A \\ CICLOVIA/CICLOFAIXA}

Entrevistador:

Número da Entrevista:

\section{Características do entrevistado}

Sexo:

Faixa etária:
( ) Masculino
( ) Jovem
( ) Feminino
( ) Adulto
( ) Idoso

1. A ciclovia/ciclofaixa é segura?

$\square \operatorname{Sim}$

$\square$ Não

2. O pavimento é adequado?

$\square \operatorname{Sim}$

$\square$ Não

3. É fácil atravessar os cruzamentos?

$\square \operatorname{Sim}$

$\square$ Não

4. A largura é adequada?

$\square \operatorname{Sim}$

$\square$ Não 


\section{QUESTIONÁRIO PARA OS MORADORES DAS IMEDIAÇÕES}

Entrevistador:

Número da Entrevista:

\section{Características do entrevistado}

Sexo:

Faixa etária:

( ) Masculino

( ) Jovem

( ) Feminino

( ) Adulta

( ) Idosa

1. Você acha que foi bom a Prefeitura ter implantado a ciclovia/ciclofaixa no seu bairro ou você acha que o dinheiro deveria ser gasto com outro benefício para o bairro?

$\square$ Sim. Por quê?

$\square$ Não. Qual outro benefício? 